

\section{TONGOBRIGA REFLEXÕES SOBRE O SEU DESENHO URBANO}

\section{CHARLES ROCHA}

LINO TAVARES DIAS

PEDRO ALARCÃO 


\section{Sumário}

- TONGOBRIGA, a cidade que há no futuro... Lino Tavares Dias (CITCEM)

II - O traçado oculto da cidade romana de Tongobriga

- O traçado oculto da
Pedro Alarcão (FAUP-CEAU)

III - Reflexões sobre o desenho urbano de Tongobriga

PARTE 1 - Conhecer Tongobriga

1.1 - Área Arqueológica do Freixo

1.2 - A Cidade

organização $\quad 48$

1.2.3 - Muralha

1.3 - Áreas Públicas. Equipamentos Identificados

1.3.1 - Termas

1.3.2 - Forum

1.3.3 - Teatro
1.3.4 - Circo

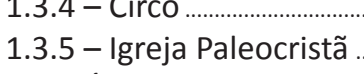

1.3.5 - Áreas Privadas. Zonas Habitacionais

PARTE 2 - Tongobriga. Contributo para a sua reconstituição

2.1 - A Cidade Romana

2.1.1 - Compreensão da

2.1.2 - Actus Quadratus

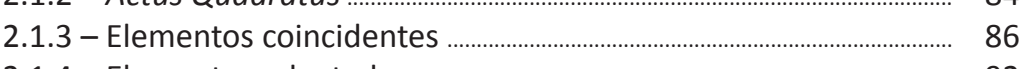

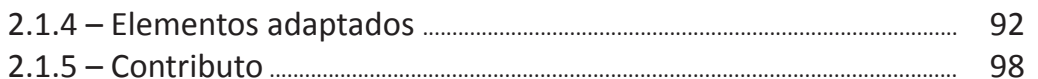

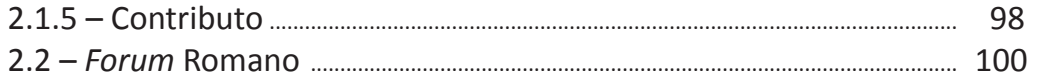

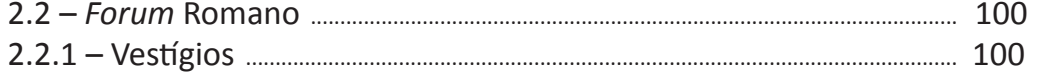

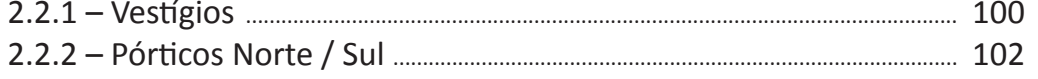

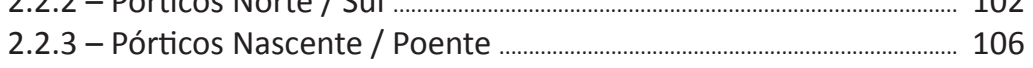

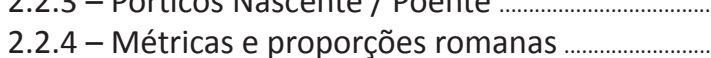

2.2.5 - Colunas ...................................

2.2.6 - Praça

120

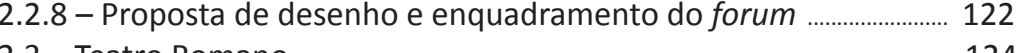

2.3 - Teatro Romano

2.3.1- Localização...........

Autores Charles Rocha, Lino Tavares Dias e Pedro Alarcão

@ 2014, Charles Rocha, Lino Tavares Dias, Pedro Alarcão e Edições Afrontamento

Edição Edições Afrontamento / Rua Costa Cabral, 859 / 4200-225 Porto

www.edicoesafrontamento.pt / comercial@edicoesafrontamento.pt

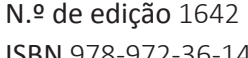

ISBN 978-972-36-1415-2

Impressão e acabamento Rainho \& Neves, Lda. / Santa Maria da Feira geral@rainhoeneves.pt

Distribuição Companhia das Artes - Livros e Distribuição, Lda. comercial@companhiadasartes.pt

Dezembro de 2014

3.3 - Comparacão geral

2.3.4 - Integracão da cavea no terreno

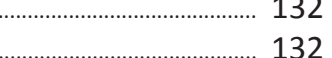

2.3.6 - Vitrúvio no Teatro de Tongobriga

2.3.7- Cavea no Tertro de Ton

2.3.8 - Corpo cénico e Pórtico Postscaena

2.4 - Anfiteatro / hiṕ́tese de implantac̃a - 142

Considerações finais

(1)

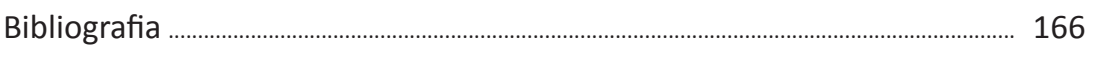

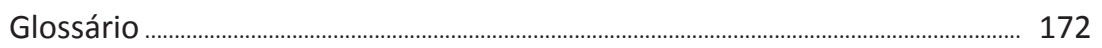

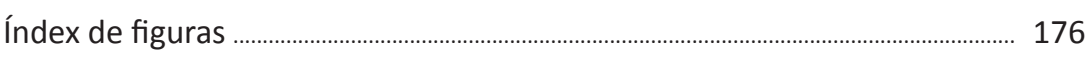

Desenhos ........................................... 
I-TONGOBRIGA, a cidade que há no futuro...

Lino Tavares Dias (CITCEM)

Decorreram mais de trinta anos sobre o início dos trabalhos de escavação arqueológica num lugar que conheci em 1980, aparentemente inóspito e onde constava que "havia uns muros diferentes, conhecidos por capela dos mouros". Diziam que nos campos vizinhos, ao longo dos tempos, apareciam "pedras trabalhadas, bilhas e pratos".

Ao longo destas décadas foi exumada uma pequena parte de TONGOBRIGA, identificada como cidade romana. Na sequência da proposta feita em 1982, num momento em que já nos era possível identificar ruínas dispersas numa área de 50 hectares, assumindo-se este espaço como "sítio arqueológico", tal foi classificado como monumento nacional. Em janeiro de 1986, com a publicação em Diário da República, recebeu a designação de Área Arqueológica do Freixo. Desde então, a gestão suportou-se no conceito de "paisagem cultural moderadamente evolutiva", integrando as marcas castrejas, romanas, paleo-cristãs, medievais, modernas e até dos nossos dias.

\section{O Lugar}

O documento mais antigo, escrito em papel, que tivemos a oportunidade de consultar sobre o Freixo data de 1726, da autoria de Francisco Xavier da Serra Craesbeek, nas Memórias Ressuscitadas da Província de Entre Douro e Minho no ano de 1726, e através dele pudemos saber que ruínas de uma "mesquita" eram então visíveis, embora tivessem sido atingidas por um raio.

O mesmo autor noticía ter achado em 1686, numa casa defronte da Igreja, uma ara ao deus romano Júpiter.

Segundo CRAESBEEK, o Freixo salientava-se pela grande feira que começava na segunda-feira da Quaresma e durava até domingo, existindo por isso "ruas com cobertos, para debaixo deles os mercadores se recolherem", reunindo muita gente "de todo o reino". Desta memória ainda restam no Freixo alguns vestígios na rua dos Judeus, no espaço central da aldeia. 


\section{De Lugar a Sítio (arqueológico)}

Na sequência das campanhas de escavação realizadas em 1980 e 1981, logo que se registaram as primeiras descobertas de ruínas, sentimos que era fundamental reafirmar a designação de "Património", fazendo-o perante a população e as autoridades, em defesa da "Iegitimidade" dos objetos e do sítio, suportada na exigência de investigação e de conservação das ruínas exumadas.

O ano de 1980 tinha sido designado como "ano europeu do património" e, desde logo, sentimos que esta designação devia verter para os comportamentos e, por isso, ser relevada pela vontade política, sancionada pela opinião pública, julgada pelo senso comum, reconhecida pelo bom senso, percecionando a afirmação das diferentes comunidades, desde a vicinal e paroquial, à concelhia, à regional, até à nacional e internacional, como bem realçou Carlos Alberto Ferreira de Almeida em Património - O Seu Entendimento e a Sua Gestão, editado em 1998 por ETNOS.

Em simultâneo, apercebemo-nos da pujança de património multidimensional, ali construído durante séculos pela ação do Homem e da Natureza, resultando a paisagem como fruto da história, da geografia e reflexo do saber empírico, casamento da natureza e da cultura.

O desafio que a escavação gradual de edifícios em ruína nos colocava era, ao mesmo tempo, o da descoberta e o da permanente avaliação e reciclagem de conceitos, assumindo-se a absoluta prioridade da investigação.

No caso da Área Arqueológica de Freixo interpretamos esse desafio da forma mais profunda, procurando perceber o território e as sucessivas marcas que o Homem foi sobre ele construindo, marcando-o indelevelmente até à contemporaneidade.

A escavação permitiu identificar as ruínas de Tongobriga e permitiu afirmar que no final do séc. I, e ainda no séc. II, surgiu uma urbe, a cidade, como organismo socioeconómico que concentrou não só elementos "residenciais" mas também uma produção artesanal especializada e, certamente, atividades sistemáticas de "troca" que justificaram a construção do forum e de outros edifícios públicos.

As cidades que os Romanos implantavam nas províncias eram uma novidade muito marcante para essas regiões, não só porque obrigavam a novos tipos e formas de habitação, mas também porque contribuíam para transformar o modo de vida tradicional. $\mathrm{O}$ urbanismo foi um poderoso instrumento político e essas novas cidades contribuíam, muito, para transformar radicalmente a organização administrativa e social. Patrick Le Roux, no livro Romains d'Espagne, editado em 1995, escreveu que "a cidade tornou-se o cimento do Império e a substância das Províncias", embora tenha acrescentado que "não interessava a que preço é que isso tinha sido conseguido".

Esta noção de transformação toma particular relevo na região do vale do rio Douro se nos recordamos do que Estrabão ${ }^{1}$ escreveu sobre esta região da Ibéria no seu texto da Geografia:

“... e os últimos são os Calaicos, que ocupam em grande parte as montanhas. (...) A rudeza e selvagismo destes povos resultam não só dos seus costumes guerreiros, mas também do seu afastamento".

Quando iniciámos a investigação na década de 80 do século XX, o povoamento antigo da região a norte do rio Douro era considerado muito modesto e limitado genericamente à romanização ${ }^{2}$ dos castros. Por isso, a gradual escavação de Tongobriga, e a identificação como cidade ex nihilo, foi-nos surpreendendo ao longo dos anos de investigação, questionando-nos se ela teria resultado de maturação dos elementos proto urbanos e, como tal, condicionada por eles ou se, pelo contrário, teria surgido de um projeto de raiz. Perante as evidências arqueológicas, julgamos que os arquitetos romanos que ali trabalharam a partir dos Flávios estavam condicionados por algumas preexistências evidenciadas por arquitetura castreja, nomeadamente um balneário vulgarmente denominado "pedra formosa" e casas de planta circular inseridas num espaço com muralha. Apesar destas evidências, percebemos que não foram suficientemente pujantes para os impedirem de implementar os critérios que traziam como modelo, embora as condições locais obrigassem à escolha de soluções que implicavam algumas adaptações nos sistemas ortogonais que Ihes serviam de método no desenho das cidades.

Apesar de serem defensores de princípios de ortogonalidade no traçado das urbes, parecia evidente que tal sistema de eixos regulares só poderia ser aplicado sobre terrenos totalmente livres e sem acidentes morfológicos que o condicionassem. Em Tongobriga parecia que as carac-

${ }^{1}$ VELOZO, FRANCISCO JOSÉ; CARDOSO, JOSÉ (1965) ESTRABÃO: Livro III da Geografia IVELOZO, FRANCISCO JOSÉ; CARDOSO, JOSÉ (1965) ESTRABÃO: Livro III da Geografia -
primeira contribuição para uma nova edição crítica, Studium Generale, Porto: Centro primeira contribuição para uma nova edição critica, Studium Generale, Porto. Centro
de Estudos Humanisticos. Belles Lettres. 
terísticas geomorfológicas não permitiam o traçado de arruamentos rigorosamente ortogonais, embora soubéssemos que, teoricamente, tal não era impeditivo da aplicação dos critérios básicos de construção da urbe.

De facto, apesar das adaptações que engenheiros e arquitetos tiveram que fazer para construir os grandes edifícios públicos em Tongobriga, os condicionalismos geomorfológicos não impediram que fosse seguido o "princípio da oportunidade" salientado por Vitrúvio, segundo o qual devia ser selecionado o melhor local para a arquitetura pública.

Em Tongobriga, embora tenham sentido a necessidade de expandir o espaço urbano e, para isso, tenham construído o centro cívico num dos lados da cidade, mantiveram inalterável o projeto clássico do conjunto monumental constituído pelo forum, basílica, templo, termas públicas e, até, pelo teatro ou anfiteatro.

O Império Romano formava um corpo com milhares de cidades autónomas, com a particularidade de a vida de uma cidade do Ocidente ser praticamente idêntica à de uma cidade da metade orienta do Império, pois qualquer alteração às práticas habituais estava sujeita a limites bem determinados.

Parece-nos que a atitude de construir termas, basílica, praça, templo e demais edifícios públicos correspondeu ao objetivo de dotar este novo centro urbano de equipamentos coletivos que, pela sua monumentalidade e "riqueza" arquitetónica, impusessem Tongobriga como centro de atração e decisão sobre a região envolvente, o seu territorium.

As fachadas dos edifícios públicos, bem identificados pelas suas tipologias, serviam também como transmissoras de uma mensagem que os Romanos pretendiam carregada de simbolismo, até mesmo como sinal de pujança que as classes dirigentes demonstravam ao criar condições que Ihes permitissem viver à romana, entendido como justo reflexo da sua participação na gestão do Império e como modo mais seguro de afirmar prestígio aos olhos dos seus dependentes locais.

Também a qualidade e rigor observados nos edifícios de Tongobriga só foi possível porque aqui se instalaram técnicos e dirigentes que não só projetaram como também acompanharam as obras e fiscalizaram as construções.

Na construção de Tongobriga identificamos alguns momentos que salientamos porque tiveram influência marcante na evolução da cidade.
O primeiro momento que a escavação arqueológica propiciou é exemplificado pelo castro construído no final do século I a.C., e que poderá ter resultado da deslocação de populações de oppida vizinhos. Construíram-no de acordo com as técnicas que conheciam e usaram a tipologia de casas de planta circular que Ihes era habitual. Algumas das casas identificadas em Tongobriga tinham poste central que suportava a cobertura em colmo, mas outras não evidenciam essa característica, levando a pensar que poderiam ter um outro tipo de travejamento de madeira que evitasse o poste central e, por isso, permitisse a instalação de lareira central, ao contrário das outras que só permitiam lareira junto da parede.

A cercar as áreas de habitações, fechando um espaço de cerca de $139000 \mathrm{~m}^{2}$, foi identificada uma muralha com perfis retilíneos, para a qual apontamos uma cronologia de construção em torno do ano zero, período genericamente denominado como "augustano". Neste período foi também construído o balneário do tipo "pedra formosa", implantado num espaço junto do troço sudoeste da muralha.

O segundo momento, identificado com o final do século I d.C., após a governação de Vespasiano, salienta-se pela construção dos edifícios públicos das Termas e do Fórum. A construção destes edifícios, especialmente as termas, foi feita em espaços muito próximos da necrópole de cremação que já ali existia para enterramento da população do castro romano. Certamente com o intuito de manterem com evidência a separação entre os espaços da vida e da morte, como determinavam os hábitos nas cidades romanas, construíram novos troços de muralha com caráter simbólico, embora com traçado irregular que manteve toda a necrópole no exterior do perímetro habitado e monumental. Com o novo perímetro da muralha o espaço interior foi ampliado de $139000 \mathrm{~m}^{2}$ para $217000 \mathrm{~m}^{2}$.

As áreas habitacionais espalhavam-se por cerca de 10 hectares, o que poderá, com risco de análise, indiciar uma população de cerca de 2500 pessoas, se calcularmos uma hipótese de ocupação de 250 pessoas por hectare servindo-nos da similaridade com outras cidades, apesar de reconhecermos a dificuldade que tem este tipo de aproximações.

A arquitetura habitacional romana em Tongobriga é fundamentalmente marcada e salientada pela qualidade da sua construção, contrariando a ideia de que a edificação privada estava muito sujeita a incêndio e a derrubes, muito por causa do uso generalizado do adobe. Mas, no território de Tongobriga, toda a construção "privada" é feita em 
granito, embora mantendo a espessura de "pé e meio" recomendada para as paredes em tijolo.

Esta é uma das razões por que a arquitetura das casas destinadas a habitação tem qualidades que se salientam em qualquer dos três tipos de casas que identificamos para uso privado: casas de circulação sequencial, casas de corredor e casas de pátio com impluvium.

Constatamos a tipologia de casas tal como as identificamos na fase de uso e com homogeneidade cronológica. Deste modo assumimos a cronologia como elemento de partida para a análise tipológica.

Pela investigação que fizemos, sistematicamente, concluiu-se que a construção dos edifícios que determinam a cidade está concentrada nos últimos anos do séc. I e no início do séc. II d.C., cerca de 100 anos após o testemunho de Estrabão.

Estamos, assim, perante duas realidades muito distintas, separadas 100 anos no tempo, obtidas por duas formas diferentes: primeira, pelo texto de Estrabão que narrava a região a norte do rio Douro como "primitiva e indígena" ainda no início do séc. I d.C. e, a segunda, pela constatação arqueológica que nos mostra uma cidade no início do século II d.C. como exemplo máximo da estruturação de um território.

O século I d.C. foi um período de grande labor em Tongobriga. Salientando que as termas foram construídas no final do século e o forum no tempo de Trajano e Adriano, foram recentemente identificadas estruturas que integravam construções monumentais do século I, anteriores à monumentalização no tempo dos Flávios.

Desta forma, em simultâneo com o "balneário castrejo do tipo pedra-formosa, terá existido um espaço construído com alguma monumentalidade durante o século I, com eventual evocação de Augusto. Ligada a esta evocação estaria uma inscrição identificada em Alpendurada e dedicada ao Imperador mas que, provavelmente, pertenceu a um templo de Tongobriga. Nesta altura o espaço a nascente do balneário estava livre, marcado pela muralha e pela necrópole de cremação no seu exterior.

Logo que foram identificados os ritmos e os tipos de edificações de Tongobriga, outras questões se levantaram sobre os motivos geoestratégicos que motivaram a construção desta cidade.

Se o imperador Augusto referiu o interesse na criação de uma província "transduriana", e tal não se concretizou, certo é que os romanos procuravam atingir o limite atlântico do Império, conquistando-o e romanizando-o.

Estas são questões que julgamos pertinentes e que motivam o debate permanente sobre o desenvolvimento de Tongobriga no âmbito das cidades romanas no norte da Península Ibérica, especialmente na vasta região drenada pela bacia hidrográfica do Douro, onde salientamos Numância, Clúnia, Tiermes, Uxama e Aquae Flaviae, entre outras, sempre com o cuidado de não perdermos de vista a amplitude geográfica, de paisagem, clima e gentes que o Império atingiu no séc. II e que Natália Correia tão bem descreveu, e sintetizou, em Somos todos hispanos, obra editada em 1988.

\section{Uso cultural do antigo}

Os "desafios do futuro" que este património arqueológico gradualmente nos foi colocando ao longo dos anos foi muito para além das descobertas que a investigação proporcionava, motivando-nos à contemplação e exigindo-nos a reutilização e a inovação. Sentimos que o desafio passava por desenvolver ações duradouras e consistentes de valorização monumental, urbana e ambiental, a que acrescentamos a rentabilização divulgativa e turística num momento em que o consumismo aplicado ao ócio cresceu como um subproduto da economia moderna, muito incentivado pelo alargamento da esperança de vida.

Se a década de 80 teve como objetivo a escavação arqueológica e a década de 90 serviu para rentabilizar e complementar com o ensino a investigação de campo e laboratorial aplicada, ao entrarmos na última década do século XX definimos como "objeto de gestão" o sítio de 50 hectares da "Área Arqueológica do Freixo", assumindo a pujança da cidade romana de Tongobriga e das marcas de ocupações paleocristãs, medievais e modernas e, ainda, a atual aldeia do Freixo.

Como objetivo, assumiu-se a melhoria da forma de percorrer Tongobriga, sem construir vínculos irreversíveis, protegendo a globalidade do sítio. Sempre defendemos que os espaços patrimoniais deviam ser espaços de consenso e de "bem-estar", que deviam ser fruídos como locais de aprendizagem permanente ao longo da vida.

Sempre defendemos que ao trabalhar-se em património construído, porque é um "produto" que não pode ser inovado, seja arquitetónico ou arqueológico, qualquer tentativa de inovação devia ser apli- 
cada à gestão e à estratégia, embora, em contrapartida, se pudesse fazer inovação operacional.

Por estas razões, desde cedo, logo nos anos 80, apresentamos ao Ministério da Cultura, através do IPPC, um "plano global de intervenção" que apontava os princípios e os processos de intervenção, assim como definia a cadeia operativa e as lógicas de tomada de decisão. Como consequência, o IPPC construiu na Área Arqueológica do Freixo, em 1986, um laboratório que desde então suportou o trabalho permanente de investigação, conservação e gestão. Também nos anos 80 foi criada, em permanência, uma pequena equipa com habilitações técnicas e científicas. Entretanto, desenvolveram-se ações de formação especializada para operários de arqueologia, incumbidos da manutenção de sítios arqueológicos, ajudando a que o sítio classificado se fosse constituindo, gradualmente, como "paisagem cultural moderadamente evolutiva", fruto de uma gestão quotidiana rigorosa do uso moderno dos solos e dos espaços de construção. A mesma perspetiva suportou a instalação da escola profissional de arqueologia no Freixo, quando foi criada em 1990, transformando o espaço classificado em oficina diária de reflexão

Sentimos que a sustentabilidade do "uso cultural do antigo" só poderia garantir-se se fosse suportado em princípios e processos de intervenção específicos.

A Área Arqueológica do Freixo caracterizava-se pela dispersão de ruínas por muitos hectares e, também, pela concentração da atual aldeia, construída em torno da pequena igreja paroquial, com as casas alinhadas ao longo de duas estreitas ruas.

A evolução do conhecimento sobre o sítio patrimonial, resultado da presença permanente da equipa de trabalho flexível, induziu ao aprofundamento da "metodologia global de abordagem ao sítio", nomeadamente na construção de infraestruturas para apoio técnico e turístico. Entendido o espaço como paisagem cultural moderadamente evolutiva, discutiram-se os "princípios de intervenção", nomeadamente as opções de "concentração" e de "dispersão" das infraestruturas. Se para a "concentração" de infraestruturas tínhamos muitos exemplos em todo o mundo, para a "dispersão" as referências eram muito escassas. No sentido de aprofundarmos a discussão na busca de opções e diretivas, promovemos e enaltecemos a discussão técnica entre arqueólogos e arquitetos, para além de outros profissionais com intervenção no Património.

Várias análises multidisciplinares suportaram a decisão de "dispersar" tudo o que viesse a ser construído ou recuperado no âmbito do plano de valorização deste sítio patrimonial.
Esta decisão foi acompanhada, em paralelo, com a decisão de "demolir" algumas construções, porque estavam sobre ruínas ou porque eram dissonantes e espúrias.

Em simultâneo, assinaram-se protocolos que reforçaram a intervenção pública e privada, viabilizando a gestão articulada de terrenos e de espaços construídos, numa manifesta afirmação de complementaridade de empenhamentos bem ilustrativa duma cultura da generosidade, daí resultando rentabilidade de esforços.

Os espaços ocupados pelas ruínas da cidade romana interligam-se com os espaços ainda habitados e usados quotidianamente, reforçando o carácter da Área como uma "paisagem construída", resultado da acção permanente dos fatores humanos sobre os naturais, aqui bem afirmados pela pujança dos afloramentos graníticos sabiamente usados pelo talhe cuidadoso que neles foi feito desde há mais de dois mil anos.

A simbiose evidente entre a natureza e a cultura humana neste espaço classificado permitiu-nos "qualificar" este sítio, desenvolvendo sobre ele estratégias, subentendidas como "políticas" para a Paisagem, permitindo a gestão numa perspetiva de desenvolvimento duradouro e sustentável, induzindo harmonia nas transformações que o desenvolvimento social e económico do início do século XXI acarretava.

$\mathrm{Na}$ Área Arqueológica de Freixo, os objetivos foram prosseguidos com recurso a uma cadeia operativa que conciliava a Investigação, a Conservação, a Restituição, a Divulgação, a Difusão e a Formação. A gestão da globalidade deste sítio arqueológico foi suportada nas normas legais de proteção, exigindo pareceres prévios vinculativos e autorizações formais para todas as intervenções, quer fossem agrícolas, artesanais, sociais ou de construção civil.

A experiência de gestão deste sítio devia ser avaliada com seriedade e maturidade. Foi, julgo, uma das primeiras experiências em Portugal aplicada à gestão partilhada de um sítio arqueológico, neste caso através de protocolo entre o Ministério da Cultura e o Município, entre 1982 e 1986. Depois, a gestão foi sempre assumida pela entidade de tutela, nomeadamente o Instituto Português do Património Cultural (IPPC) até 1992, o Instituto Português do Património Arquitetónico e Arqueológico (IPPAR) de 1992 a 1995, o Instituto Português do Património Arquitetónico (IPPAR) de 1995 a 2006, e a Direção Regional de Cultura do Norte desde 2007.

Neste sítio patrimonial, de forma permanente e homogénea, todas as pequenas e médias ações ou empreendimentos foram previamente salvaguardados por trabalhos prospetivos e de investigação que permitiram a análise aprofundada da autenticidade dos solos e das 
estruturas sobre ele construídas ao longo dos séculos, viabilizando, em simultâneo, através da investigação e do restauro, a "restituição", gradual dos espaços milenares que o Homem definiu, trabalhou e usou para servir nas suas múltiplas funções.

Ao construirmos diariamente o passado através da exumação das ruínas e dos espólios associados, estivemos a resgatar através da Arqueologia, como método de revelação do monumento, a integridade da cidade romana sobre a qual se instalou uma população medieval cujas atividades de mercado eram ainda evidentes no século XVIII e XIX. A todas estas marcas sucedeu-se a atual aldeia, totalmente inserida na Área Arqueológica de Freixo, o que constitui o último estrato da sequência que cronologicamente nos transporta com marcas de autenticidade até à atualidade, deixando-nos, agora, na época da denominada "globalização", a responsabilidade de resgatarmos, com autenticidade, o resto do passado desconhecido, construindo em simultâneo, harmoniosamente, a Paisagem Cultural do século XXI.

$\mathrm{Na}$ elaboração do "plano de valorização multidisciplinar", depois de definidos os princípios de intervenção, sintetizados nos infinitos dos verbos investigar, proteger, valorizar e percorrer, refletiu-se muito sobre os "processos estratégicos e instrumentais", de que resultou a decisão de conciliar a recuperação e a reabilitação, defendidos como opções para os projetos de arquitetura e especialidades. Outra opção foi tomada para as novas construções, assumindo-se o controle de risco da afirmação do novo objeto arquitetónico na sua relação com o bem patrimonial, neste caso a ruína. $O$ conceito de afirmação foi aqui desenvolvido nas situações em que a modernidade se assumiu como linguagem arquitetónica, através de projetos de raiz implementados em sítios arqueológicos, sob a forma de edifícios de apoio, definindo-se a afirmação por "ocultação", por "incrustação" ou por "reversão".

Na busca da conciliação de processos de intervenção resultaram distintas soluções na abordagem ao espaço do sítio patrimonial, consequência da nossa opção, defendida intransigentemente, na procura da diversidade de arquitetos que assumissem a autoria dos projetos, cientes da importância das correntes, escolas, técnicas e gosto de cada um deles.

Apesar da diversidade de opções existentes muito se discutiu, assumindo-se intransigentemente a ideia de salvaguardar as ruínas e paisagem milenar, ambas constituídas como fatores determinantes na conceção arquitetónica de grande parte das intervenções. Reconhecendo-se as opções para a mesma intervenção, refletiu-se muito sobre os resultados da harmonização e da diversidade.
Um dos exercícios prospetivos multidisciplinares que foram feitos induziu à simulação das preferências de diferentes tipos de visitante a desfrutar e compreender o espaço desde o ano zero até ao presente. Um cidadão ou grupo que quisesse visitar a estação arqueológica de Freixo podia dirigir-se à Receção, instalada no centro da aldeia, num pequeno edifício que tinha servido de habitação e onde funcionava a barbearia da aldeia até aos anos 80 do século passado. Era um pequeno edifício térreo construído diretamente sobre o afloramento granítico que servira de alicerce à ruína romana. Esta construção foi reabilitada em 2000 e 2001.

Agregado a este projeto foi também recuperado outro pequeno edifício que servira para recolha de gado onde se instalaram sanitários com boas condições de uso e tratamento ambiental. Vulgarmente a instalação de sanitários não é projeto que se saliente num sítio patrimonial, mas em Freixo, numa aldeia sem saneamento básico e onde todas as casas tinham sido feitas sobre afloramento granítico, a construção daquele tipo de infraestruturas obrigou a condições especiais. Para isto foi recuperado um pequeno edifício, para aí instalar sanitários.

Em articulação funcional com este espaço de acolhimento do sítio arqueológico, foi construído um auditório, com alguma polivalência, instalado num edifício novo construído no local onde existia uma habitação de dois pisos, edificada em 1973. Tratava-se de uma casa cujo projeto desqualificava o sítio patrimonial, edificada onde existira uma antiga casa agrícola térrea coberta a colmo. A construção de dois pisos foi demolida em 1999 e, depois de limpo todo o espaço, o projeto de arquitetura para o auditório integrou-se no plano global de requalificação do espaço central da aldeia, privilegiando a ocultação. Neste auditório o visitante deveria ter informação cientificamente certificada ao ver a projeção multimédia sobre o "mundo romano" e as especificidades da bacia hidrográfica, do vale do Douro e de Tongobriga.

Depois de ter assistido à projeção multimédia o visitante poderia, então, iniciar o circuito pelas ruínas da cidade de Tongobriga percorrendo, por exemplo, a casa do poço, a casa do impluvium e a casa das escadas. É uma zona de domus com cronologias desde o século II d.C., mero exemplo das amplas zonas habitacionais romanas.

A visita a esta zona habitacional devia ser complementada com a observação dos achados mais importantes que as escavações arqueológicas evidenciaram. Este desiderato, suportado na decisão de dispersar as infraestruturas de apoio, poderia acontecer em dois núcleos expositivos. Um desses núcleos, assumido como "espaço interpretativo 
da vida quotidiana" foi minuciosamente implantado sobre uma zona habitacional romana, respeitando alinhamentos do urbanismo de Tongobriga, procurando privilegiar, em simultâneo, a articulação visual com a ruína próxima mas também com a paisagem envolvente e longínqua, de que salientamos, as serras e franjas do Marão, Aboboreira e Montemuro, vale do Tâmega e os montes onde pontificavam castros.

Procurava-se que o visitante, quando estivesse no interior do edifício percorrendo-o, tivesse relação visual direta com as ruínas de onde as peças eram provenientes.

Neste edifício, em espaços diferenciados, cada um com temática de grande riqueza científica, seriam valorizadas através de objetos da vida quotidiana em Tongobriga as "vulgaridades" do quotidiano e do discreto utilitário, mas também manifestações da intimidade do habitante evidenciadas, por exemplo, pelos altares a Tongo, a Júpiter, a Fortuna, a Cibele e, também, pelo discreto encanto dos bonitos objetos pessoais.

Deveria, também, ser evidenciada a importância da circulação de produtos e bens, salientando a travessia do território pelas vias romanas que alimentavam a globalização de então.

Em resposta aos pressupostos indicados para a gestão global da Área Arqueológica do Freixo, o projeto de arquitetura deste edifício favoreceu a "incrustação" no centro da aldeia, embora privilegiando a ortogonalidade da cidade romana.

A descoberta em 2002 da basílica paleocristã sob a Igreja Paroquial, com a particularidade dos seus mosaicos, poderia proporcionar leituras e interpretações muito consistentes sobre as alterações que o Cristianismo provocou nos rituais religiosos dos séculos IV a VI. Os vestígios desta basílica com mosaicos, por razões que a razão não explica, encontram-se encerrados sob o soalho da igreja, fruto de obras recentes da responsabilidade da Paróquia de Freixo.

Depois, o visitante continuaria a caminhar pelos espaços das zonas habitacionais romanas até ao forum. Este conjunto constitui o núcleo comercial, político, religioso e social de Tongobriga e é um magnífico exemplo da capacidade que a arquitetura e engenharia romana tinham para intervir na paisagem, remodelando o terreno até que este se moldasse convenientemente à implantação das novas construções. A mesma qualidade de projeto e de adaptabilidade é notória no edifício dos banhos públicos. Este conjunto monumental tem sido alvo de trabalhos de manutenção permanente, constituindo uma experiência positiva de intervenção de pequenas equipas permanentes de operários e técnicos especializados.

Depois, seguindo, afinal, o ritmo natural da vida, a visita prosseguia para um dos espaços da necrópole romana. Esta observação deveria ser facilitada pelo segundo núcleo expositivo, instalado sobre sepulturas de cremação, servindo estas como vitrinas que acolhem as peças identificadas. Reconhecemos que este projeto podia concretizar um projeto singular, embora arriscado. Este núcleo incluía não só os acervos mas também explicações sobre os ritos da morte com que as culturas milenares marcavam a "vida".

uso cultural de qualquer sítio patrimonial deve dar prioridade à criação de condições para que os visitantes possam fruir sem "conflito de interesses" as ruínas e os espaços, rentabilizando-se pela "apreensão direta" dos resultados científicos que a investigação propicia.

Este foi o desiderato para a Área Arqueológica do Freixo.

No plano de fruição de um vasto sítio arqueológico e patrimonial como é a Área Arqueológica do Freixo, induzindo naturalmente visitas prolongadas, sentimos a necessidade de criar um espaço de cafetaria e restaurante, servindo não só de apoio aos visitantes mas também às populações locais.

Assumindo-se a "dispersão" das infraestruturas de apoio como princípio de intervenção neste sítio arqueológico, foi assumida a construção de um edifício destinado a cafetaria e restaurante num espaço central da Área Arqueológica, enquadrando-se por "incrustação" na zona do forum. $\mathrm{O}$ desafio apontado ao arquiteto foi o de que pudesse ser valorizada a dupla e simultânea relação com a ruína próxima e com a paisagem envolvente. Tal foi conseguido neste edifício com o uso de paredes em vidro. Deste modo assumiu-se também a exigência de simplificar a relação do novo edifício com a envolvente circunstancial, obrigando-nos a fazer demolições de barracos e arrumos agrícolas desqualificados que ali existiram.

No caso de Tongobriga, para além de melhorar as condições de fruição pública, procurou-se também melhorar as condições de armazenamento dos acervos e dos equipamentos diariamente usados nas escavações arqueológicas, na manutenção e na conservação das ruínas e, por isso, foi construído "de raiz" um edifício de apoio que reuniu todas as condições técnicas. 
Em contrapartida, para o edifício do laboratório de investigação construído nos anos oitenta, no núcleo central da aldeia do Freixo, tinha sido recuperada uma fachada do século XIX, que então tinha sido construída com pedra retirada das ruínas romanas. Este laboratório fo a estrutura fundamental de suporte à gestão e à investigação de todo o sítio arqueológico.

Ao longo de mais de trinta anos dissemos que estávamos certos que a harmonização do conjunto de novos equipamentos e a ampliação dos espaços escavados com ruínas arqueológicas visitáveis, complementando-se, continuariam a suportar um espaço de excelência

\section{$\mathrm{O}$ arqueólogo o que pediu ao(s) arquiteto(s)?}

Desde 1980 que o sítio arqueológico e patrimonial esteve sempre sob gestão de arqueólogos, incidindo como prioridade na investigação mas também, gradualmente, ao longo dos anos, foi incidindo numa estratégia que procurou responder às solicitações da sociedade. Os arqueólogos assumiram a responsabilidade de reconhecer os restos milenares e o seu espírito. Assumiram o discurso interpretativo, e a sua responsabilidade científica em ambiente transdisciplinar.

Ao longo dos anos pedimos aos arquitetos que tivessem intervenção em Tongobriga em dois campos de trabalho:

- Na restituição, em desenho, das ruínas até ao limite do que a arqueologia podia confirmar

- Na valorização do sítio, através de projetos de arquitetura com a salvaguarda de controlo de risco de presença intrusiva de elementos atuais que contaminassem a interpretação do passado.

Ao longo de mais de trinta anos de trabalho público, regular e sistemático, exumamos alguns espaços determinantes de Tongobriga onde se evidenciou o conjunto de edifícios públicos e privados que enalteceram a arquitetura da cidade romana.

Mas este sítio arqueológico continua a encerrar ruínas e conhecimento que desafiam as novas gerações de investigadores.

Sempre defendemos que muito havia para exumar e estudar. Continuamos a defender que muito há para investigar.
Ao longo de mais de três décadas tivemos a oportunidade de coordenar equipas transdisciplinares. Desta partilha de trabalho salientamos a que tivemos com distintos arquitetos, com distintas formações e sensibilidades. Esta foi uma partilha que defendemos desde o início dos trabalhos nos anos 80 .

O diálogo, a discussão e a reflexão partilhada com distintos arquitetos, de diversas gerações, com diferentes formações, sensibilidades e capacidades, contribuíram indelevelmente para o crescimento de um sítio patrimonial que em 1980 era só mais uma aldeia em abandono.

Ao arqueólogo exige-se a responsabilidade metodológica e científica da escavação arqueológica, da sua estratégia e da interpretação estratigráfica, assim como as interpretações cronológicas e espaciais. No caso específico das ruínas romanas, rapidamente fomos confrontados com a necessidade de fazer restituição em desenho.

Conceptualmente a "restituição" pode ser desenvolvida com diferentes amplitudes e distintos objetivos. Nos trabalhos de Tongobriga consideramos a restituição como uma interpretação da arquitetura, elaborada a partir de hipóteses desenvolvidas até ao limite do que a investigação arqueológica pode confirmar.

Fizemo-lo sempre como contribuição para o aprofundamento das problemáticas da investigação e por vezes com algum intuito informativo em ambiente pedagógico, mas nunca o fizemos com intuitos divulgativos ou expositivos.

As primeiras experiências foram concretizadas por uma equipa que integrei com o arquiteto Fernando Maia Pinto e com um jovem arquiteto brasileiro que estava a estudar arquitetura clássica, como bolseiro em Portugal, nos anos 80 . Fizeram-se as primeiras restituições em desenho, concentrado no edifício das termas romanas, quer a partir das plantas quer a partir dos alçados e ainda das eventuais volumetrias das salas e dos espaços. Foram documentos de trabalho fundamentais para suportar a discussão teórica e para suportar o evoluir das buscas de novos elementos que pudessem confirmar as dúvidas ou, quantas vezes, anulá-las. Decorridos mais de vinte anos sobre essas reconstituições, entretanto publicadas em teses académicas e em encontros científicos, continuam a servir positivamente como suporte para discussões.

Entretanto, com o decorrer dos anos, a escavação permitiu exumar espaços diversos de Tongobriga que propiciaram novos desafios. Alguns desafios internacionais, tidos não só com equipas de investigação das várias cidades romanas da bacia do Douro, mas também 
partilhados com arquitetos e colegas professores da Faculdade de Arquitetura do Porto e das Universidades de Roma Tre e de Valladolid, permitiram elevar o nível dos desafios de restituição de Tongobriga enquanto cidade romana.

O desafio académico lançado a Charles Rocha foi feito vinte e muitos anos depois de começarem as escavações, num momento em que a investigação de Tongobriga tinha evoluído muito, desafiando a um trabalho muito vasto. $O$ desafio lançado pelo Prof. Pedro Alarcão, que partilhei, foi grande. Por exemplo, muito se discutira o uso do passus no sistema modular pelos arquitetos clássicos, bem assim como o uso do actus quadratus no urbanismo. Mas não tinha havido nenhum estudo aplicado a todo o espaço de Tongobriga. Depois, o desafio de restituição da implantação dos edifícios públicos exigia trabalho simultâneo entre arquiteto e arqueólogo, materializado nas dúvidas apontadas pelo primeiro e nos esclarecimentos que a escavação arqueológica propiciou. A metodologia de abordagem que propusemos era inovadora, num trabalho articulado e complementar entre arqueólogo e arquiteto.

O resultado do trabalho apresentado neste livro expressa um desafio evolutivo, e serve, em simultâneo, como desafio para novas investigações. Foi um trabalho rigoroso, suportado naquilo que a escavação propicia e, por isso, científico.

Os resultados agora apresentados abrem perspetivas de trabaIho mas também formulam um desafio exigente deixado para o futuro, incentivando novas restituições. É, por isso, um trabalho que prevejo entusiasmante.

Também no campo da valorização do sítio os diálogos entre o arqueólogo e os arquitetos foram intensos e frutuosos. Desde os anos 80 que começou a sentir-se a necessidade de pensar na "construção" de infraestruturas que garantissem a melhoria de condições de trabaIho de investigação do sítio arqueológico. Desde cedo foi defendida a ideia de que os materiais recolhidos nas escavações deveriam, sempre que possível, ser tratados, conservados e estudados in situ.

Foi este objetivo que esteve na base do primeiro desafio feito à equipa de arquitetos do então IPPC sediada no Porto.

$\mathrm{O}$ arqueólogo pediu ao arquiteto que projetasse para uma aldeia em ruína um edifício que fosse o centro do "trabalho de futuro" daquele sítio patrimonial. Assumiu este desiderato o arquiteto Fernando Maia Pinto, autor do edifício que acolhe o laboratório. 0 projeto foi preparado em 1987 e de imediato foi construído em terrenos adquiridos no centro da aldeia, onde existiam barracos que serviam como arrumos agrícolas adossados a uma magnífica fachada em granito, a qual veio a confirmar-se ter sido feita com pedras retiradas das ruínas romanas.

Deste "edifício" irradiou, desde então, toda a estratégia técnica e científica para o sítio e nele se suportou o pensamento sobre a região.

No início da década de 90 surgiu o desafio do sítio arqueológico servir de oficina e base diária de formação certificada de técnicos de arqueologia, com vertentes de campo e laboratório. Era algo que nunca tinha acontecido em Portugal.

Prosseguindo a perspetiva de valorizar a aldeia, foi recuperada uma casa que estava parcialmente em ruína para aí instalar a sede da escola profissional de arqueologia. Foi também o arquiteto Fernando Maia Pinto quem assumiu a autoria do projeto de recuperação do edifício. Neste caso, o arqueólogo pediu ao arquiteto que fizesse o projeto de adaptação do edifício de forma a responder, em simultâneo, às exigências de uma escola com laboratórios para ensino e às condicionantes do edifício preexistente naquela aldeia.

Tal como acontecera com o projeto do laboratório de investigação, também este projeto contribuiu para qualificar a aldeia e respondeu em simultâneo às exigências duma escola deste tipo. Em ambos os caso as pessoas, os utentes, também tiveram que aprender a nova maneira de usar este "novo" tipo de edifícios em ambiente patrimonial classificado.

Entretanto, em 1994, foi sentida a necessidade de concretizar um plano global executado sobre um levantamento topográfico atualizado de todo o espaço classificado e da respetiva área envolvente de proteção. Este trabalho foi realizado pelos arquitetos António Portugal e Manuel Maria Reis, permitindo-nos dispor desde então de um bom documento de planeamento.

Depois, em 1995 e 1996, aos mesmos arquitetos foi pedido que fizessem o projeto de recuperação de dois pequenos edifícios situados no centro da aldeia para servir de apoio a visitantes.

Num desses edifícios o desafio foi a construção de sanitários públicos, coisa aparentemente simples mas tornada complexa, não só pela aldeia não ter saneamento básico e ser construída totalmente sobre ruína, mas também por ser um equipamento pouco valorizado nestes ambientes rurais. Pedimos, propositadamente, que fosse um projeto que marcasse a diferença pela qualidade da infraestrutura. Os resultados finais foram muito bem atingidos. 
Muito cedo foi sentida a necessidade de equipar a estação arqueológica com um pequeno auditório. Tal foi concretizado com um projeto da responsabilidade do arquiteto Miguel Tomé. Para tal o pedido suportou-se no uso de um espaço no centro da aldeia onde existira uma casa com pouca qualidade e que, por isso, tinha sido demolida pelo IPPAR. $O$ uso intenso do auditório foi prova do sucesso da ideia.

Entretanto, com o decorrer dos anos, as escavações arqueológicas exumaram muitos materiais cujo depósito já não era suportado pelo laboratório de investigação construído nos anos 80 . Mas, para além dos acervos, também os equipamentos que foram servindo a estação arqueológica exigiam novas condições de manutenção. A arquiteta Joana Borges foi incumbida de desenvolver um projeto que, de forma muito "adormecida" na paisagem, permitisse responder plenamente ao que tinha sido pedido: reserva para espólio e oficina para equipamentos.

Se até aqui as preocupações tinham privilegiado a melhoria das condições de investigação, manutenção e conservação do sítio arqueológico, o início do século XXI trouxe os desafios do turismo. Na ausência de um museu associado ao sítio, optou-se por confirmar a dispersão das estruturas "musealizadas" de apoio aos visitantes.

Ao arquiteto Miguel Tomé foi pedido do projeto do edifício para o núcleo da vida quotidiana. Foi pedida "uma vitrina" inserida nas ruínas mas onde o visitante pudesse entrar e, quando dentro dela, pudesse simultaneamente contemplar "muito" a paisagem construíd envolvente, próxima e longínqua.

Mas o fluxo turístico exigiu uma infraestrutura de cafetaria e de restauração. Foi pedido ao arquiteto que fizesse relação direta com as ruínas e com a paisagem envolvente, de onde certamente veio a população milenar indígena de Tongobriga. $\mathrm{O}$ arquiteto Jorge Romualdo fo responsável por um edifício enquadrado no espaço do forum e cuja transparência foi testada pelos inúmeros pássaros que morreram em choque contra as paredes em vidro.

Outros pedidos foram feitos pelos arqueólogos e outros projetos foram desenvolvidos por arquitetos. Alguns com muita qualidade não foram concretizados, mas os construídos servem de laboratório comportamental sobre um sítio classificado que deveria estar em permanente avaliação e isto porque deveria estar, também, em permanente crescimento por nele se acrescentar conhecimento. Foi isso que se pediu a todos ao longo de mais de trinta anos de trabalho.
Procuramos perceber como o território foi conformado ao longo de milénios e procuramos perceber como devemos continuar a construir património, o que é um enorme desafio contemporâneo.

Recordo o que Estrabão salientou quando escreveu que "os povos montanheses que habitavam o lado setentrional da lbéria, como os Calaicos, os Astures e os Cântabros, tinham rudeza e selvagismo, e tal resultava não só dos seus costumes guerreiros, mas também do seu afastamento.

Sendo longos os caminhos por terra e por mar para chegar até eles, não tendo relações com outros, não tinham sensibilidade e humanidade".

E acrescentou que na época de Estrabão já "sofriam menos deste mal, em virtude da paz e presença dos romanos".

Como salientou um estudioso da palavra, Álvaro Gomes, numa conferência intitulada "O nome da pedra", feita em 2010, em "Tongobriga, falamos de restos pré-romanos (sinto ou pressinto o caráter dolente e melancólico daquele prefixo pré-), porque, sendo romana a deusa subsistência, o resto é apenas o rasto de substratos. A cultura autóctone cede a uma outra, contaminante, dominante e, frequentemente e por definição, eliminante".

Esta era uma noção de periferia que era apontada ou interpretada a partir do centro de então, a partir de Roma.

Numa interpretação atual perante o que conhecemos do sítio, esta noção de periferia do século I depois de Cristo foi assumida como um desafio, entendida como resultado da geoestratégia política do século de Augusto para a bacia do rio Douro. Na periferia aparentemente tudo estava mais longe, tudo era mais difícil de atingir, o que valoriza o esforço aqui aplicado pelo homem, fosse romano ou romanizado.

Em síntese, assumindo-se as exigências duma gestão integrada que devia suportar-se em complementaridade de estratégias cientificas, pedagógicas e turísticas, rentabilizando a fruição dos resultados propiciados pela investigação, procurou-se compreender a modernidade contemporânea e as exigências de rigor e de ética nas relações com o passado, dando sentido ao pensamento que Marguerite Yourcenar, em Memórias de Adriano, atribuiu ao Imperador Adriano:

"Construir é colaborar com a terra; é pôr numa paisagem uma marca humana que a modificará para sempre...". 
Quando, em Outubro de 2010, lançámos a Charles Rocha, finalista de Arquitectura da Universidade do Porto, o desafio de realizar uma reconstituição desenhada do hipotético teatro romano de Tongobriga, a Estação Arqueológica do Freixo atravessava um período de algum impasse. Decorridos 30 anos desde a sua identificação e posteriores campanhas sistemáticas de escavação, sempre sob a direç̧ão de Lino Tavares Dias, estavam registados os vestígios arquitectónicos exumados, realizada a sua interpretação e publicados os seus resultados $^{1}$. Foi também durante este período que se criaram e construíram as estruturas necessárias ao funcionamento de uma unidade integrada de gestão patrimonial, ao nível da investigação, formação, exposição e apoio ao visitante, tal como tinha idealizado o seu descobridor ${ }^{2}$. Todos estes equipamentos se implementaram, sobretudo através de reconstruções, na própria aldeia do Freixo, que se viu assim reabilitada e receptora de uma dinâmica que talvez nunca tivesse vivido ${ }^{3}$.

Os frutos da colaboração entre arqueólogos e arquitectos, com vista à interpretação dos vestígios arqueológicos, matéria hoje aceite e suficientemente reconhecida nacional e internacionalmente, tinham igualmente já sido comprovados pelo autor deste texto e Lino Tavares Dias, noutras ocasiões ${ }^{4}$.

É sabida a importância e papel preponderante do arqueólogo na identificação e interpretação dos vestígios, mas também as suas limitações. Jorge Alarcão, embora com ressalvas, estabelece uma separação, com a qual não nos revemos, ao considerar que a reconstituição planimétrica é, geralmente, trabalho de arqueólogo, com a útil cola-

${ }^{1}$ Lino Tavares Dias, Tongobriga, Tese de Doutoramento apresentada à Faculdade de Latras da Universidade do Porto (policopiada), 1995; Lino Tavares Dias, Tongobriga. Lisboa: IPPAR, 1997. 2Lino Tavares Dias, "Gestão Integrada da Area Arqueologica do Freixo-Tongobriga: conII.. Série, n.o 16. Almada, 2008, pp. 82-91.

Esta dinâmica decorre do aumento significativo de fluxo de pessoas, entre alunos, professores, técnicos e visitantes, que utilizam os equipamentos instalados no Freixo. A população residente, cerca de 50 pessoas na area classificada, aumenta durante o dia para cerca de 200 pessoas, graças sobretudo à existencia da Escola Profissional de ${ }^{4}$ Ver Actas do Seminário Internacional de Arquitectura e vrqueo ogia:

Ruina Contribuicões entre campos disciplinares - FAUP 2008, Lino Tavares Dias Pedro Alarcão (org.), Porto, FAUP publicaç̃es, 2011. 
boração do arquitecto ${ }^{5}$, sendo esta mais necessária para imaginarem a elevação de um edifício e as suas coberturas, tarefa em que os arqueólogos estão geralmente mal habilitados ${ }^{6}$.

A arquitectura deve ser entendida como um processo único que tem como objectivo satisfazer simultaneamente a utilitas, a firmitas e a venustas. Um processo, tal como salienta Leon Battista Alberti, constituído pelo desenho e pela construção, em que desenho (delinea menta) ${ }^{7}$ é entendido como instrumento de trabalho ${ }^{8}$, com regras próprias e, por esse facto, constituído por matéria disciplinar específica ${ }^{9}$.

Se este princípio se aplica no acto do projecto, pode também ser analisado em sentido contrário, da ruína ao construído, tendo o autor da interpretação que deduzir a lógica compositiva do edifício (o seu traçado, distribuição entre as partes e proporção) em relação com a sua lógica de materialização (o seu sistema estrutural e técnica construtiva) E ninguém dispõe de melhores ferramentas e método para empreen-

5 “A reconstituição planimétrica é, geralmente, trabalho de arqueólogo, embora, nesta fase, a colaboraçâo de arquitecto (ou de desenhador com larga experiencia de dese nho arquiteconico) seja útil, ou mesmo necessáría". Jorge Alarcão, "A colaboraçãao de Arquitectos com Arqueoologos", in Actas do Seminário Internacional de Arquitectura e Arqueologia: Interpretar a Ruina. Contribuições entre campos disciplinares - FAU 6 "Ora os arqueólogos

cão de um edifício. Habituados a escate mal habilitados para imaginarem a elevade gatos, de olhos rentes ao chão. Mesmo quando treinados em axonometrias, têm dificuldade em imaginar coberturas. Nos telhados, porém, pode encontrar-se confirmação ou desmentido de uma determinada identificaçăão planimétrica". Idem, p. 12. 7 "A arte edificatória, no seu todo, compõe-se de delineamento e construção. Toda a função e razão de ser do delineamento resume-se em encontrar um processo, exacto e perfeito, de ajustar e unir entre sil linhas e angulos, afim de que, por meio daquelas e destes, se possa delimitar e definir a forma do edifício. Ora e função e objectivo do proporrã̃o exacta uma escal conveniente e uma distribuicão agradável ade ta ta da que a conformação de todo o edifício assente unicamente no próprio delineamento. delineamento não depende intrinsecamente da matéria: mas é de indole tal que nos damos conta que em vários edificicios existem as mesmas linhas, quando neles se verifica uma só e mesma forma, isto é, quando as suas partes, e a disposição e ordenamento de cada uma delas correspondem entre si em todos os seus ângulos e linhas. E será leg timo projectar mentalmente todas as formas, independentemente de qualquer maté ria: consegui-lo-emos desenhando e pré-definindo angulos e linhas com orientação e uma conexão exactas. Assim sendo, segue-se que o delineamento será um traçado exacto e uniforme, mentalmente concebido, constituído por linhas e ângulos, levado a
cabo por uma imaginação e intelecto cultos" Leon Battista Alberti, Da Arte Edificatóri [De Re Eddificatoria], traducão de Arnaldo Espírito Santo, introduc̃ão e notas de Mário Krüger, Lisboa, Fundação Calouste Gulbenkian, 2011 (1.. ed. 1485) Livro L, 1, pp. 18-21. ${ }_{8}^{8}$ Pierre Caye e Françoise Choay ou Arnaldo Espírito Santo e Mário Krüger utilizam nas traduções de Re Æđdificatoria, de Leon Battista Alberti, o termo delineamento, ao invés de Giovanni Orlandi, que opta pelo termo desenho. Segundo Mário Krüger, "o termo delineamento evoca, assim e apesar da polissemia que apresenta, a representação por meio de linhas ou traços do objecto que se constró bem como os mecanismos de concepção que the está associados" Mario Kruger," "As leturas e a recepp̧ão do De Re AEdificatoria de Leon Battista Alberti", consultado em: http://homelessmonalisa.dara. uc.pt/Mariokruger.

"A margem dos valores arqueológicos e das razões históricas, existe a disciplina da Metamorfosis de monumentos y teorias de la restauración, Madrid, Alianza Editorial 1992 (1.a ed. 1988), p. 53 der a tarefa da dedução da ausência do que o arquitecto, utilizando precisamente o desenho como instrumento de análise e concepção.

No caso particular da arquitectura romana, o trabalho de interpretação é de certa forma facilitado pelo facto de esta se fundamentar em cânones tipológicos e construtivos largamente difundidos, permitindo assim, mais facilmente, avaliar o modelo adoptado e a sua aplicação; embora também saibamos que, apesar das características referidas, esta mesma arquitectura demonstra igualmente uma enorme capacidade de adaptação ao lugar. Assim, o modelo elaborado resulta da análise dos vestígios, do conhecimento que se tem do sistema arquitectónico, tipológico e dos hábitos construtivos utilizados, bem como da especificidade desse mesmo lugar.

Por esta razão, salienta Jorge Alarcão, "se a colaboração do arquitecto é indispensável para reconstruir a elevação e volumetria de um edifício antigo de que só temos ruínas, o arquitecto, porém, deve ter uma modéstia: a de reconhecer que não Ihe basta dispor da planta do arqueólogo (sempre necessariamente cotada) e do manual de Vitrúvio. Vitrúvio escreveu o seu tratado no tempo de Augusto - e a arquitectura romana evoluiu muito ao longo da história romana subsequente. Vitrúvio é um manualista - e os arquitectos romanos não foram todos obedientes discípulos, sem imaginação própria, sem originalidade. Vitrúvio privilegiou um estilo helenístico - e a arquitectura romana manteve tradições históricas e especificidades regionais que aquele tratado não contemplou"10.

E termina, afirmando que "o arquitecto que assume o encargo de imaginar como seria um edifício romano hoje em ruínas [ou uma cidade] tem que saber muito de história da arquitectura antiga (e da tecnologia da construção daquele tempo $)^{111}$.

Foi este desafio que lançámos a Charles Rocha, conscientes de que nem nós próprios reuníamos todas as condições necessárias para empreender tal tarefa.

E a partir da proposta inicial, de realizar uma reconstituição desenhada do hipotético teatro romano de Tongobriga, acabou por se propor uma interpretação desenhada para a cidade e para o seu centro cívico: o fórum, o teatro e um hipotético anfiteatro.

As regras (cânones) seguidas por Charles Rocha apoiam-se no traçado regulador da cidade (já identificado por Lino Tavares Dias para a

${ }^{10}$ Jorge Alarcão, "A colaboração de Arquitectos com Arqueólogos", in Actas do Seminário Internacional de Arquitectura Arqueologia: Interpretar a Ruina. Contribuiç̃os entre campos disciplinares - FAUP 2008, op. cit., p. 12.

${ }^{1}$ Idem, ibidem. 
área habitaciona $\left.\right|^{12}$ ), concebido a partir do actus quadratus ${ }^{13}$. E é suportado na unidade de medida actus e nos seus submúltiplos, pe e passus ${ }^{14}$ que se procura encontrar a lógica da cidade e dos seus eixos estrutura dores, bem como da implantação dos seus edifícios e a sua organização

Assim se apontaram várias hipóteses para a reconstituição do fórum, nomeadamente para a dimensão da sua praça, para o desenvolvimento do seu enigmático sistema porticado envolvente e para a posição do templo.

Assim se apontou um traçado possível para o hipotético teatro, que, quando comparado com o seu congénere de Bracara Augusta permite imaginar o desenvolvimento da sua cávea e o limite do seu pórtico de postscaenae que, a Sudoeste, teria seguido o alinhamento do fórum.

E assim se apontou uma hipótese para a localização do hipotético anfiteatro, depois de identificada uma zona com uma depressão morfológica, replicada para o anfiteatro a distância de três actus entre o eixo do teatro e o eixo do fórum e implantada a elipse do seu traçado hipotético. As coincidências encontradas, um troço de muro ainda não identificado anteriormente e uma mudança de direcção no traçado de um pequeno caminho, são as suspeitas e a contribuição que se deixam à arqueologia.

Estas, como todas as outras, são hipóteses formuladas, entre a razão e a intuição, que precisam ser confirmadas, com trabalhos de limpeza, sondagens ou escavações pontuais, acompanhados da consequente interpretação dos vestígios encontrados, em necessária colaboração interdisciplinar ${ }^{15}$.

O nosso interesse em estudar a ruína, fragmento de arquitec tura do passado, prende-se com o facto de continuarmos a ver esta disciplina, tal como refere Giorgio Grassi, como a síntese de problemas

${ }^{12}$ Lino Tavares Dias, “A urbanização do Noroeste peninsular: O caso de Tongobriga”, Norte da Peninsula lbérica, Porto, 1999, $P$. 103

metros. O actus quadratusé um quadrado cujomana, que corresponde a cerca de 35 e corresponde à área de terreno lavrada por uma junta de bois, desde o nascer do so até ao meio-dia.

14 A unidade de medida romana pe, em Tongobriga, corresponde a $29,58 \mathrm{~cm}$. Por sua ${ }_{15}$,

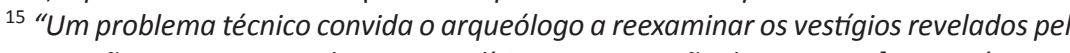
escavação e a procurar neles novos indicios. A construção da maqueta [a que nós acres-

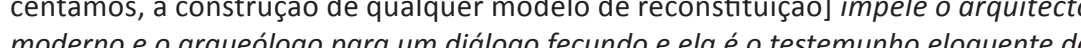
sua complementaridade e colaboraç̃ó". Jorge Alarcão, Robert Etienne e Jan-Claude Golvin A maqueta do centro monumental flaviano Conimbriga, Lisbo Instituto Português de Museus-Museu Monográfico de Conimbriga, 1994, p. 42. antigos e novos, entre a citação, imagem da tradição e de permanências, e a inovação. Para este autor, através das suas obras, os antigos mestres transmitem-nos "ideias e ensinamentos, assim como instruções, conselhos, respostas correctas, ou seja, experiência"116. Por isso repete constantemente nos seus escritos que a origem de uma obra de arquitectura está noutra obra de arquitectura, que os seus projectos são "projectos que repetem coisas já ditas"17.

"Como podem as ruínas ajudar a construir o presente? As ruínas devolvem-nos o que Ihes damos, o que Ihes perguntamos desde o presente, transformado, acrescentado com a sua proposta radical, isto é, a sua mensagem de essencialidade ${ }^{\prime \prime 18}$.

Foi esta, pensamos, a maior lição que Charles Rocha retirou das ruínas da cidade romana de Tongobriga.
${ }^{16}$ Giorgio Grassi, "Antiguos Maestros", in Arquitectura lengua muerta e otros escritos,

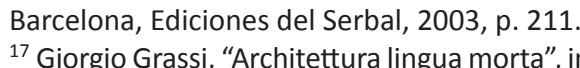

${ }^{17}$ Giorgio Grassi, "Architettura lingua morta", in Architettura lingua morta - Architecture

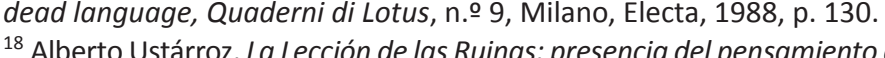

en la arquitectura, Barcelona, Fundación Caja de Arquitectos (Col. Arquíthesis, no o 1), 1997, p. 286. 
centro cívico da cidade romana de Tongobriga era constituído por equipamentos que correspondiam a diferentes funções do mundo romano, tais como: a religião, a política, o comércio e o lazer. Numa cidade de província, estes equipamentos faziam parte de uma política de romanização dos povos conquistados, onde auxiliavam na implementação: da cultura, da religião e do quotidiano da vida romana. Mas estes permitiam, acima de tudo, que a cidade funcionasse de forma organizada.

O que se pretendeu com este projecto de investigação foi o estudo do Centro Cívico Romano, da antiga cidade de Tongobriga. Este foi o resultado da expansão do espaço urbano (por volta do séc. II d.C.), e deu origem a um conjunto de equipamentos públicos que impuseram Tongobriga como centro de atracção e decisão (civitas).

Através deste estudo pretendeu-se compreender a vivência e a integração na paisagem do Centro Cívico, bem como chegar a uma reconstituição conjectural do mesmo.

Foi igualmente pretendido salientar a utilidade dos processos de desenho e da lógica de pensamento do arquitecto, neste campo de trabalho; demonstrando como a análise em desenho e o cruzamento de informação, bem como a limpeza de certos elementos estranhos, pode auxiliar na detecção de pistas fundamentais à investigação; e, desta forma, trazê-las à luz da análise e discussão.

A escolha desta antiga cidade de Tongobriga como caso de estudo advém de se tratar de uma ruína do período romano. Pois, por esta ser "(...) construída segundo cânones tipológicos e construtivos largamente difundidos, nos fornece muitas pistas para a interpretação de novos fragmentos - comparando os vestígios existentes com os exemplos conhecidos - chamando, de uma forma clara, os arquitectos à participação na sua interpretação"

Na primeira parte do trabalho procura-se dar a conhecer, ao leitor, a Cidade Romana de Tongobriga; uma etapa que, no contexto da

${ }_{1}^{1}$ Pedro Alarcão, Construir na ruína: a propósito da cidade romanizada de Conímbriga, 2009, pp. 21-22. 
investigação, equivaleu à fase de análise e familiarização com o enquadramento do objecto de estudo. A aproximação ao espaço do Centro Cívico foi feita assim do geral para o particular, e de forma gradual.

Começa-se por realizar uma breve exposição do recente histórico dos vestígios desta cidade: o início e progressão das escavações realizadas; o conjunto de medidas tomadas para a gestão e conservação dos vestígios, assim como as medidas para o apoio das escavações no parque arqueológico.

Seguidamente, é feita uma apresentação "geral" da cidade romana de Tongobriga; uma explicação da sua origem, localização e relação com o território, assim como da sua importância e evolução. É feita, também, uma explicação da organização da cidade, recorrendo à informação existente.

Depois, analisam-se individualmente cada uma das estruturas da cidade; fazendo-se, assim, uma distinção entre as estruturas pertencentes às áreas públicas e às áreas privadas (zonas habitacionais).

Nas áreas públicas expomos os equipamentos até hoje identificados, que são: as termas, o forum, o teatro, o circo, a igreja paleocristã. Nas áreas privadas fazemos uma clara distinção dentre as diferentes zonas escavadas, assim como uma distinção entre duas fases de construção na cidade; as denominadas arquitectura castreja e arquitectura romana.

Desta forma, a primeira aproximação à cidade de Tongobriga, e desenvolvimento da análise, vai de encontro com os factos e a informação existente sobre a área arqueológica e os vestígios arqueológicos ali exumados.

Esta parte do trabalho forneceu um conjunto de dados e ferramentas essenciais à investigação; pois auxiliaram no processo de análise e pesquisa, que, por sua vez, permitiu a especulação fundamentada na reconstituição do Centro Cívico de Tongobriga.

Essas ferramentas de pesquisa assentaram essencialmente no conhecimento e compreensão dos vestígios arqueológicos identificados na estação do Freixo; no entendimento do seu significado, assim como na análise às suposições levantadas até aos dias de hoje principalmente as relacionadas com a localização e formalização do Centro Cívico; e, por fim, na criação de uma cronologia com a origem e evolução da cidade de Tongobriga (quer documental, quer de vestígios arqueológicos), para se ter um enquadramento da sua posição no tempo e história.
Para acompanhar o discurso da primeira parte deste projecto de investigação, foi feito essencialmente o uso de documentação desenhada, e disponibilizada pela Estação Arqueológica do Freixo². Foram apenas usados, ocasionalmente, desenhos elaborados para o efeito de análise imediata (que não se encontravam realizados) e que assim facilitaram o entendimento e conhecimento do caso de estudo.

A propósito desta particularidade, deve-se referir que, após a análise dos dados existentes, foram realizados expressamente para esta investigação um conjunto de desenhos, cujo objectivo foi produzir um registo completo da cidade e, desta forma, ferramentas de análise.

Sobre a importância do registo completo, é de realçar que só assim se tornou possível criar uma planta em que constem todos os vestígios de que se tem conhecimento, e vê-los, assim, em conjunto ${ }^{3}$.

Sobre o mesmo registo, e para se poder compreender a evolução da cidade e das suas estruturas, realizaram-se três desenhos de fases distintas: fase de arquitectura castreja, século I a.C. (Des. 1.04); fase de arquitectura romana, século II d.C. (Des. 1.05); e estado actual (Des. 1.02).

Quanto à metodologia utilizada para a representação deste conjunto de desenhos, tiveram-se em linha de conta critérios de desenho que permitem distinguir os vestígios dos paramentos, dos paramentos reconstituídos, assim como distinguir os próprios paramentos das soleiras de porta ${ }^{4}$.

Estes elementos constituíram elementos de trabalho essenciais para a análise e o desenvolvimento deste trabalho.

Na segunda parte do trabalho apresentado, procura-se dar uma leitura continuada e sequencial da análise, até se chegar às propostas de reconstituição de cada equipamento (por forma a dar ao leitor uma noção dos vários recursos que foram usados para se atingir esse fim); o que se torna um desafio, pois nem sempre este tipo de investigação decorre de forma linear e continuada. Existem sempre avanços e

Exemplos: levantamentos dos vestígios, planta altimétrica, perfis, fotografias aéreas, ilustrações, entre outros.

Reuniram-se os desenhos existentes e, em conjunto com a Estação do Freixo, localizaram-se os vestigios da muralha para os situar no desenho.

OS desenhos existentes encontravam-se detalhados de forma a lerem-se pedra-a-pedra todos os vestigios a descoberto em Tongobriga; embora na perspectiva do do arquitecto a mesma não é adequada. Para o arquitecto, é mais importante ter-se uma leitura limpa dos espaços e distinguir-se os compartimentos de cada equipamento, assim como perceber-se a transição entre cada espaço e como tal se realiza. 
recuos, que resultam de argumentos mais ou menos fundamentados, e que só a determinado ponto se tornam evidentes e comprovados.

Assim, é feita uma breve análise da cidade de Tongobriga segundo elementos desvendados no decorrer da investigação. De seguida, são analisados os equipamentos do centro cívico: forum, teatro e hipotético anfiteatro.

No caso do forum, analisam-se os vestígios existentes, de forma a perceber como o seu espaço se encontrava ocupado, e como estariam os seus elementos de composição distribuídos.

No caso do teatro, procura-se propor um traçado a partir dos vestígios existentes e, desta forma, compará-lo com outros teatros conhecidos da mesma época, enquadrando-o, por fim, no centro cívico.

No caso do hipotético anfiteatro, analisa-se um conjunto de indícios, por nós identificados, que aparentam uma curvatura orientada na mesma direcção que o teatro, e que parecem sugerir a posição de uma cavea.

Para se atingir o objectivo lançado, recorremos a três ferramentas essenciais, que visaram desvendar novas pistas e obter nova informação para se avaliar e considerar na reconstituição do Centro Cívico. Foram elas: a comparação com outros modelos, os preceitos de Vitrúvio e, o mais importante, o desenho.

A comparação com outros equipamentos romanos da mesma tipologia, que se encontram ou se encontravam nas mesmas condicionantes, ajudou a obter paralelismos com a situação do Centro Cívico de Tongobriga.

O recurso a preceitos teóricos vitruvianos, definidos para a construção de cada um dos equipamentos estudados, assim como a localização e o traçado, permitiram rectificar vestígios e adquirir nova informação.

Por último, o recurso ao desenho de análise e métodos lógicos de pensamento em arquitectura permitiu a obtenção de pistas, como já referido, sendo este o recurso mais valioso e conciliador de toda a informação obtida, pois auxilia o cruzamento de dados, para se detectarem e comprovarem novas pistas acerca do Centro Cívico Romano de Tongobriga e a sua integração na cidade.

Além destes, mais recursos surgiram no decurso da análise, assim como novas evidências arqueológicas, que contribuíram para um melhor alcance do objectivo traçado.
No final, apresenta-se uma proposta de reconstituição desehhada para o centro cívico de Tongobriga, em que os elementos adoptados resultam de forma directa das experiências realizadas.

Deste modo, é realizada uma síntese, evocando as conclusões provisórias que se foram construindo ao longo da investigação, em cada um dos equipamentos, ao mesmo tempo que se confrontam essas considerações, quando se vêem os mesmos em conjunto, como Centro Cívico. 


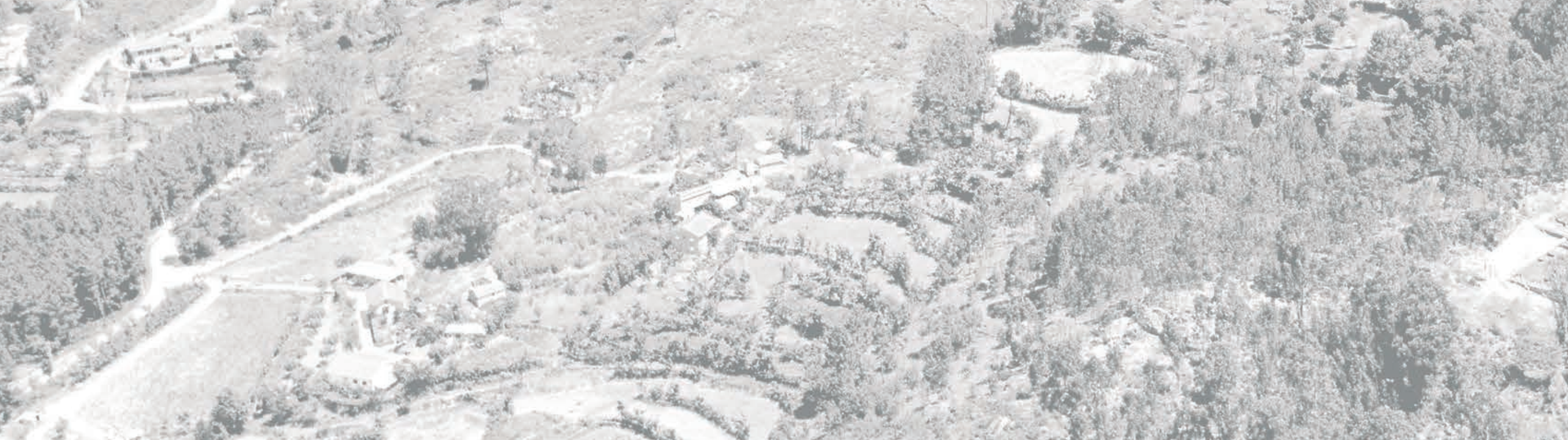
(1)

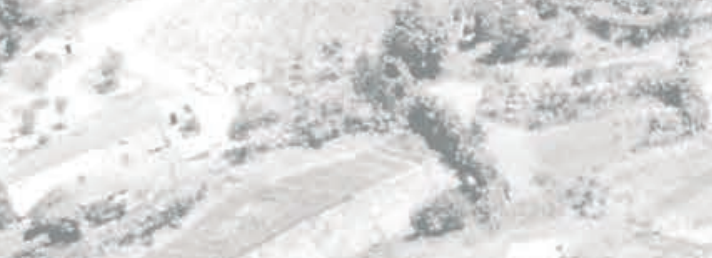

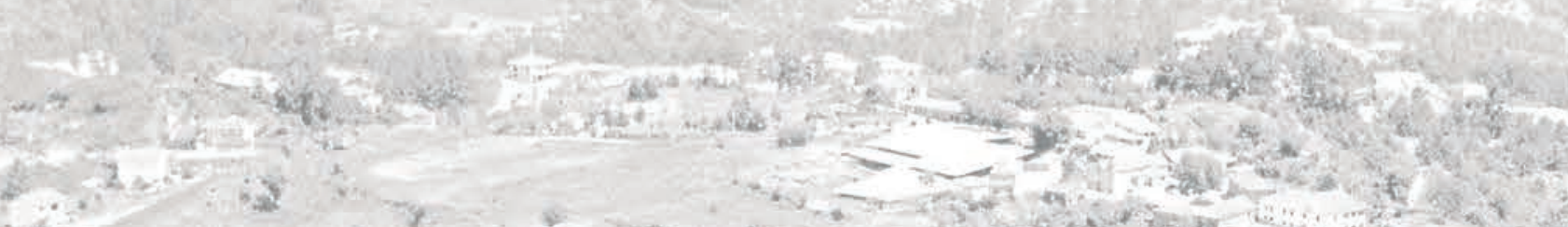

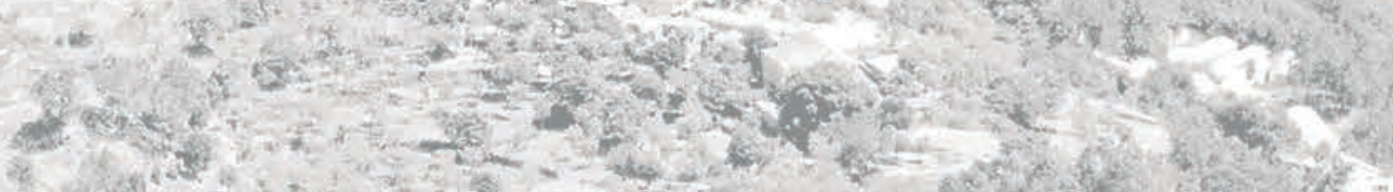

xit $x^{2}+x^{2}=$

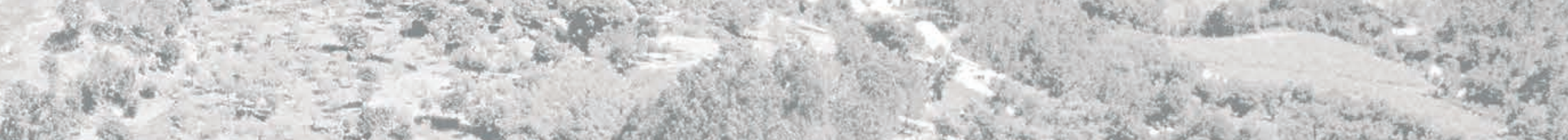

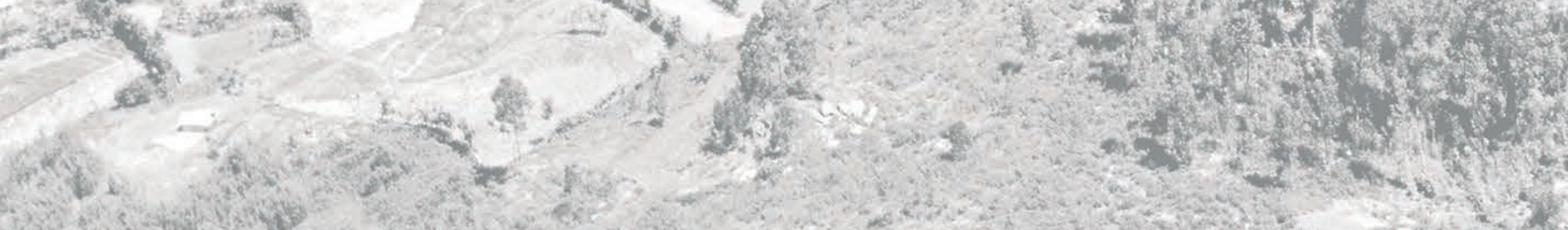

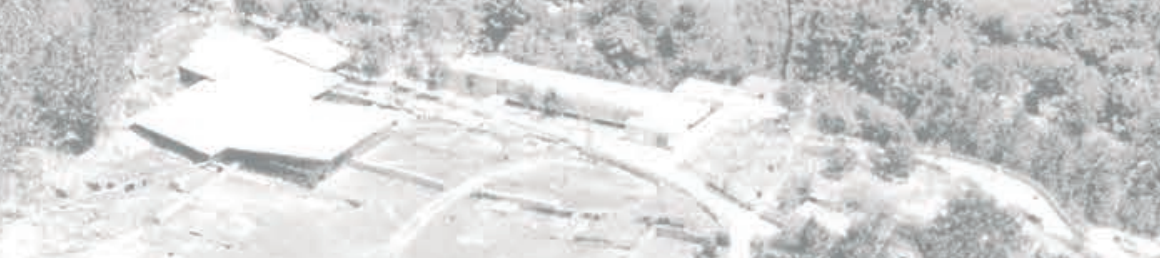

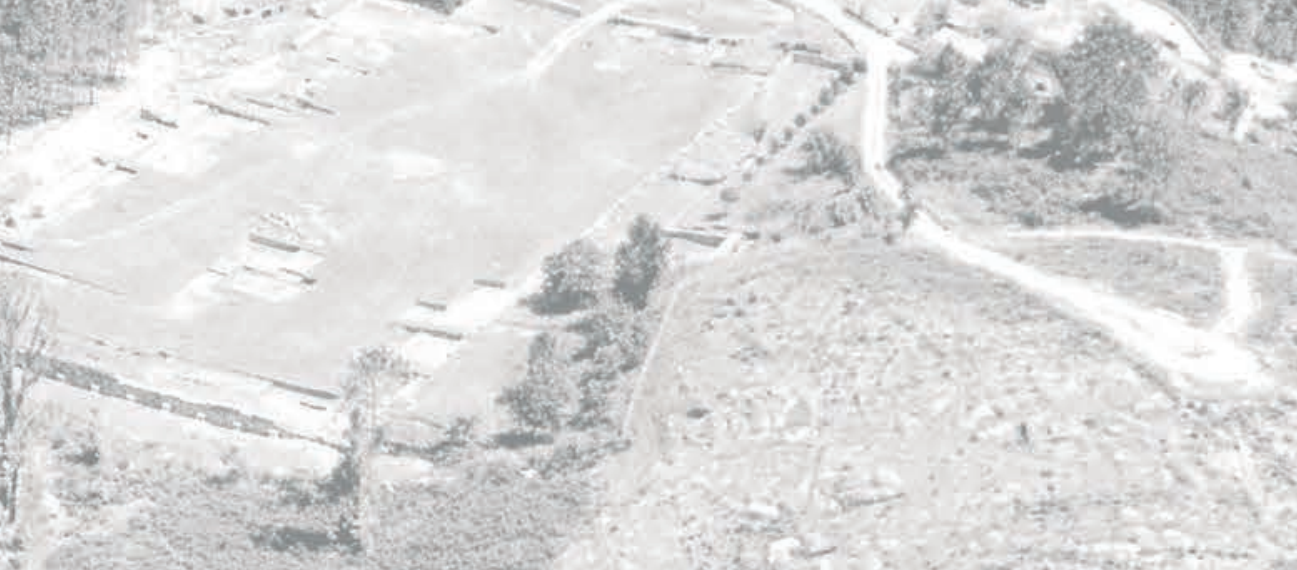

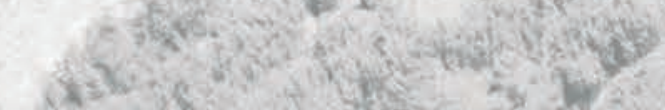

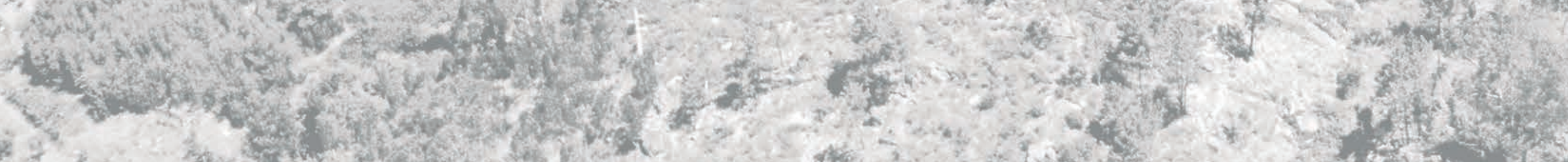

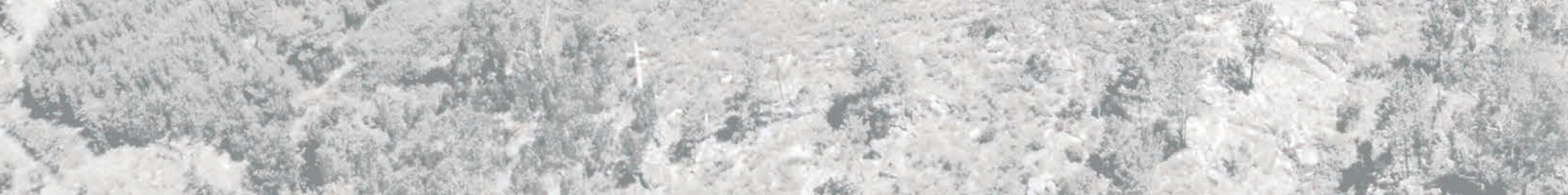
S.

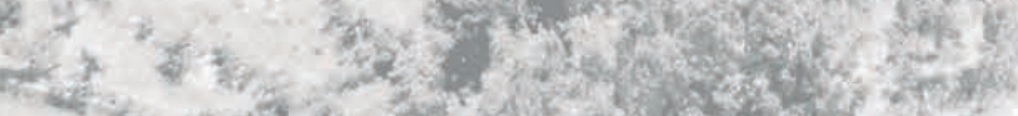



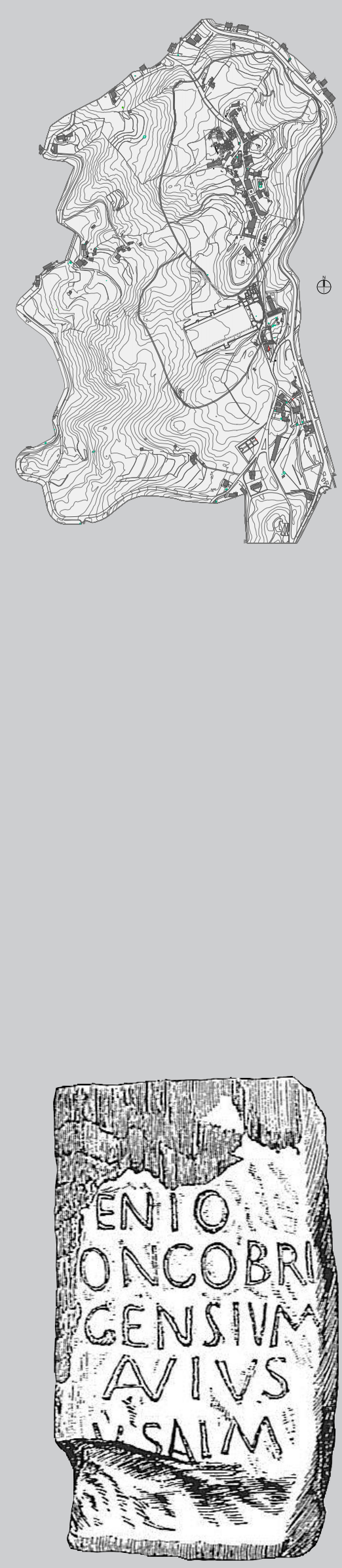

Fig. 1 - Ara consagrada Genius Tongobri-
cencius, onde se lê:

$\mathrm{V}($ otum).
S(olvit). $A($ nimo)

\section{1 - Área Arqueológica do Freixo ${ }^{1}$}

A cidade romana de Tongobriga localizava-se onde hoje se pode encontrar a pequena aldeia do Freixo (figs. 2 e 3), pertencente ao Concelho de Marco de Canaveses, no distrito do Porto. Foi identificada por um grupo de investigadores, coordenado pelo arqueólogo Lino Tavares Dias, que começou as escavações com método arqueológico ${ }^{2}$ no Verão de 1980, na então denominada "capela dos mouros" (fig. 4). Aquele conjunto de muros, identificados como romanos, veio a revelar um complexo termal romano e abriu espaço às posteriores descobertas (figs. 5,6 e 7).

Na sequência dos achados aqui identificados esta área foi classificada como Monumento Nacional, pela Lei n. 1/864, e compõe actualmente a denominada Área Arqueológica do Freixo, que se tem construído progressivamente desde então.

Aqui se instalou um Gabinete de Investigação ${ }^{5}$ permanente, na década de 80 do século $X X$, que ainda hoje continua a ser a estrutura fundamental para a gestão e investigação de todo o sítio arqueológico (fig. 9). Em 1990 foi inaugurada, no centro da aldeia, uma Escola Profissional de Arqueologia, o que veio a transformar este sítio arqueológico também num lugar de aprendizagem (fig. 10).

Recentemente, perante o lançamento do projecto "Reviver Tongobriga" ${ }^{\prime \prime}$, um conjunto de equipamentos foi projectado com o objectivo de complementar o parque arqueológico e as estruturas já existentes. Destes, estão construídos: um Auditório ${ }^{7}$ (fig. 11), um Núcleo Expositivo de Vida Quotidiana ${ }^{8}$ (fig. 12), um restaurante e cafetaria9 (fig. 13), e um Núcleo de Apoio para a arrumação de ferramentas e aparcamento de veículos usados nas escavações ${ }^{10}$ (fig. 14). Em projecto, encon-

${ }_{1}^{1}$ Para mais informação acerca da actualidade e futuro da Área Arqueológica do Freixo, consultar Lino Tavares Dias, “Área Arqueológica do Freixo. Futuro?”, in Tongo2 briga. Breves Reflexóes, 2003.

2. grada cenín tongobicensim,

textares; para mais informação, ver textos em Tongobriga. Contributo Documental, 1999

Diario da Republica, Decreto-Lei n.o 1/86.

6 "Projecto promovido pelo I IPPAR e aprovado no âmbito da Medida Desconcentrada da Cultura do Eixo 3 do Plano Operacional da Regiáa Norte. Este projecto, para o periodo 2000 a 2006, perspectiva a gradual concretização de aç̧ōes que permitirão responder aos desafios que apontamos para este sitio arqueologico com 50 hectares classificados

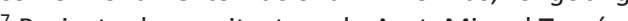
8 Projecto de arquitectura do Arqt. Miguel Tom

${ }^{9}$ Projecto de arquitectura do Arat Jorge Romualdo.

${ }^{10}$ Projecto de arquitectura da Arqt a Joana Borges.
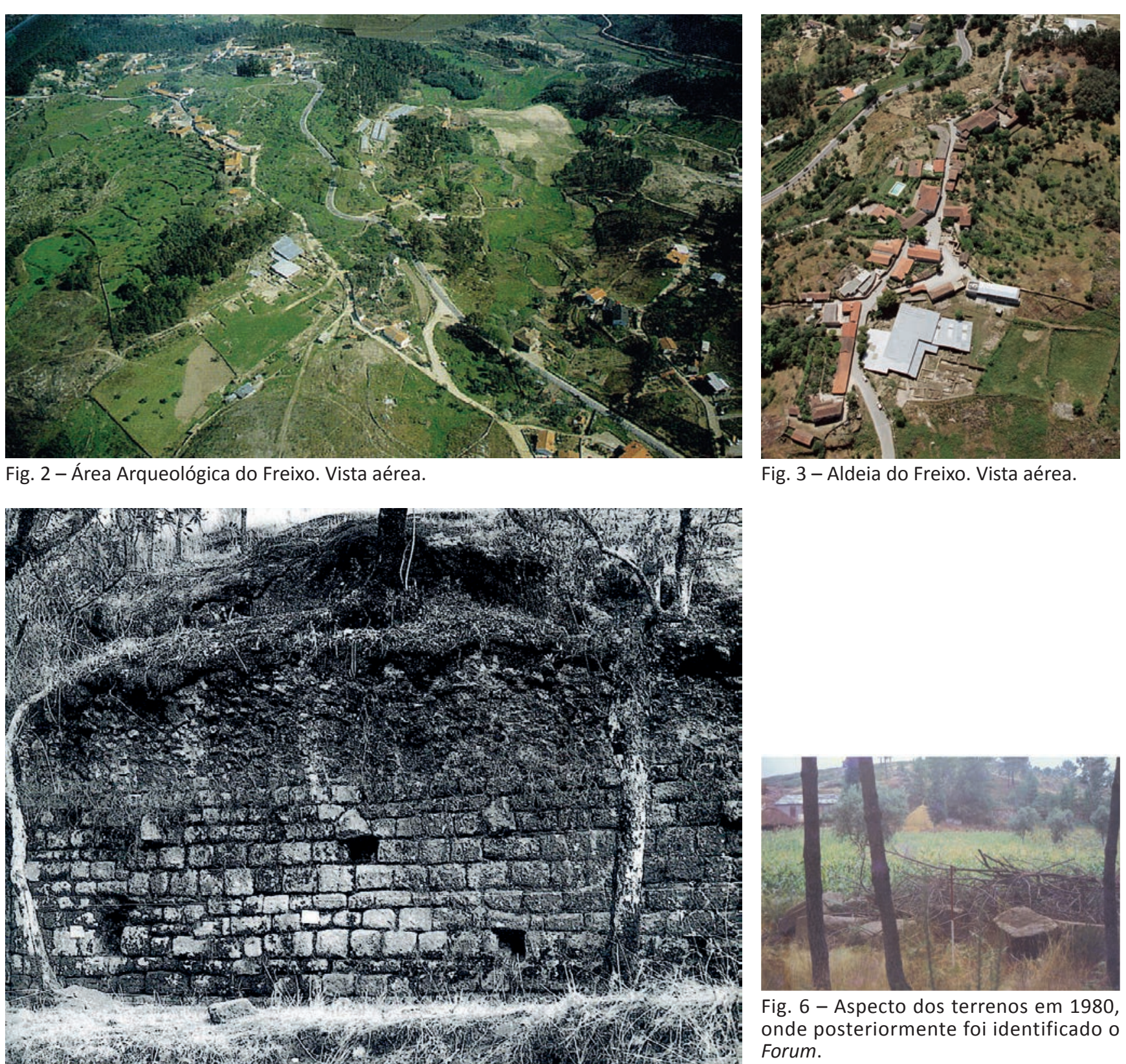

Fig. 6 - Aspecto dos terrenos em 1980,

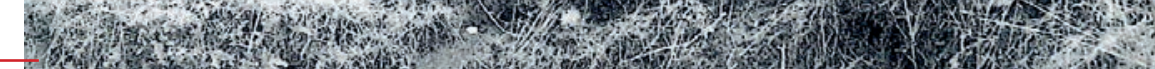
inde posteriormente foi identificado o Fig. 4 - "Capela dos Mouros". Fotografia de época.
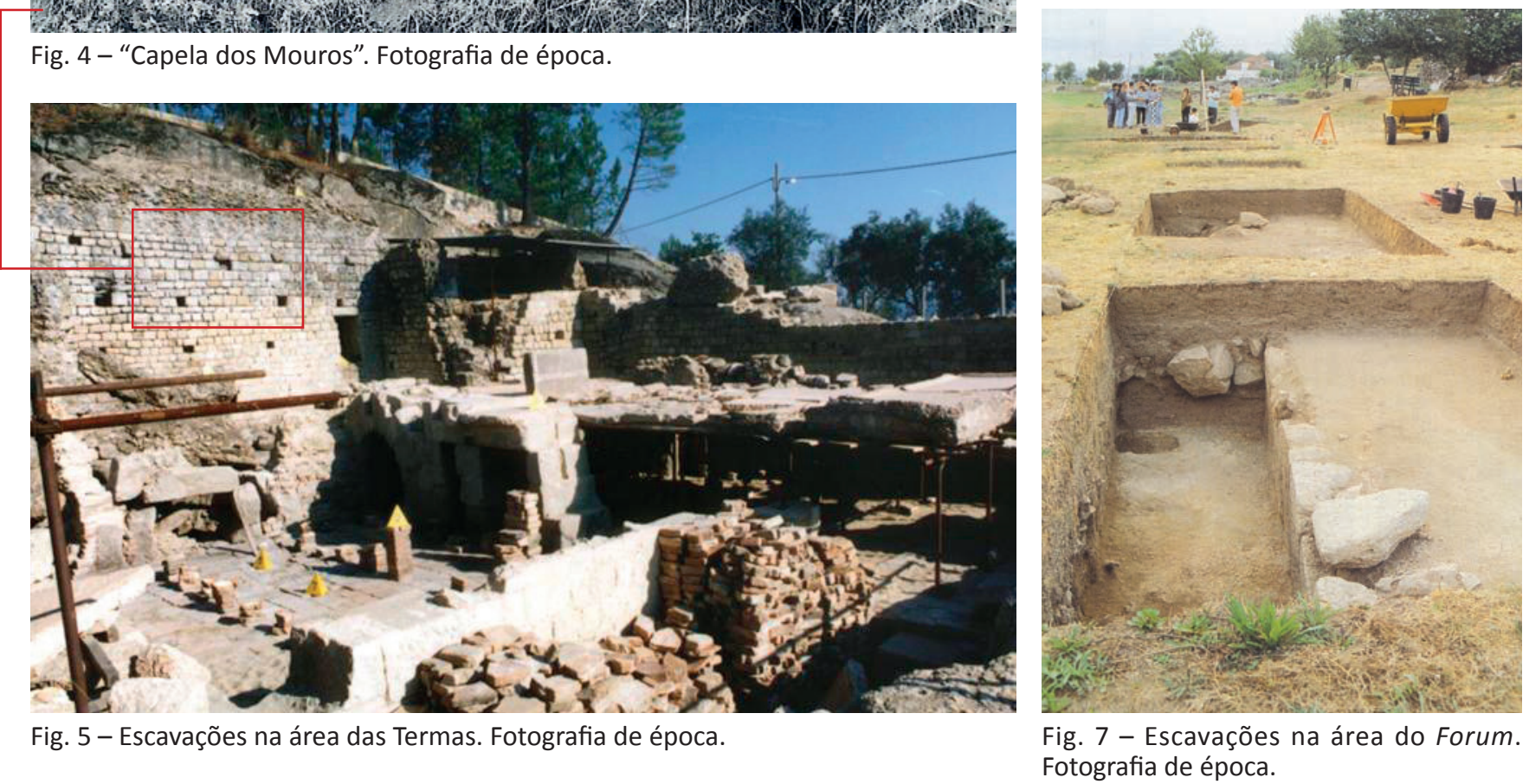

Fig. 7 - Escavaçōos
Fotografia de época. 
tra-se um Núcleo Expositivo de Ritualidade ${ }^{11}$ e umas novas instalações para a Escola Arqueológica do Freixo ${ }^{12}$.

Assim, a Área Arqueológica do Freixo tem-se desenvolvido gradualmente sobre os espaços ocupados pela ruína da cidade romana ${ }^{13}$ mantendo a harmonia com os espaços ainda habitados e usados quotidianamente pelos residentes locais (fig. 8).

O espaço arqueológico atraiu um movimento diurno de pessoas que atribui muita vida à aldeia do Freixo e aos seus espaços habitados. Tendo a Escola de Arqueologia e o Gabinete de Investigação/ Posto de turismo como dois pólos de atracção, a passagem de alunos, de professores, de investigadores e de turistas é bastante frequente. A carência desse movimento é notada essencialmente no fim-de-semana e nas férias do calendário lectivo.

Outras iniciativas têm sido tomadas para a valorização deste sítio arqueológico, nomeadamente: a criação da Associação de Amigos de Tongobriga, que procura promover e lançar discussões contemporâneas pertinentes; bem como a formalização de um protocolo com a Universidade de Brown nos EUA ${ }^{14}$. Recentemente, uma iniciativa da Câmara Municipal do Marco de Canaveses foi recebida pela Área Arqueológica do Freixo com muito agrado: essa iniciativa foi um Mercado Romano, que se realizou em Junho de 2011.

Todo este conjunto de medidas (projectos e iniciativas) vem auxiliar e complementar o que é um caso exemplar na gestão do património, em concordância com a vivência quotidiana do sítio arqueológico.

Por palavras de Lino Tavares Dias: "Na Área Arqueológica do Freixo, os objectivos têm sido prosseguidos com recurso a uma cadeia operativa que concilia a Investigação, a Conservação, a Restituição, a Divulgação, a Difusão e a Formação, assumindo esta uma dimensão crescente com a Escola Profissional de Arqueologia"15.

Este conjunto de premissas leva a uma correcta filosofia de intervenção e gestão patrimonial, entendendo o monumento na multiplicidade dos seus contextos históricos, territoriais e artísticos mas, sobretudo, dentro da paisagem que o conformou.

${ }_{11}^{11}$ Projecto de arquitectura da Arqt. J Joana Borges. ${ }_{12}^{12}$ Projecto de arquitectura da Arqt.. Cristina Guedes.

${ }^{13}$ Antes da implantaçăao de cada edificio são realizadas escavações, por forma a não

${ }^{14}$ Este protocolo permite uma colaboração entre as duas identidades, numa nova visão tena de indivíduos, provenientes da Universidade de Brown, participaram nas escava ç̃es em curso.

${ }^{15}$ Lino Dias, Tongobriga. Breves Reflexões, 2003, p. 83.

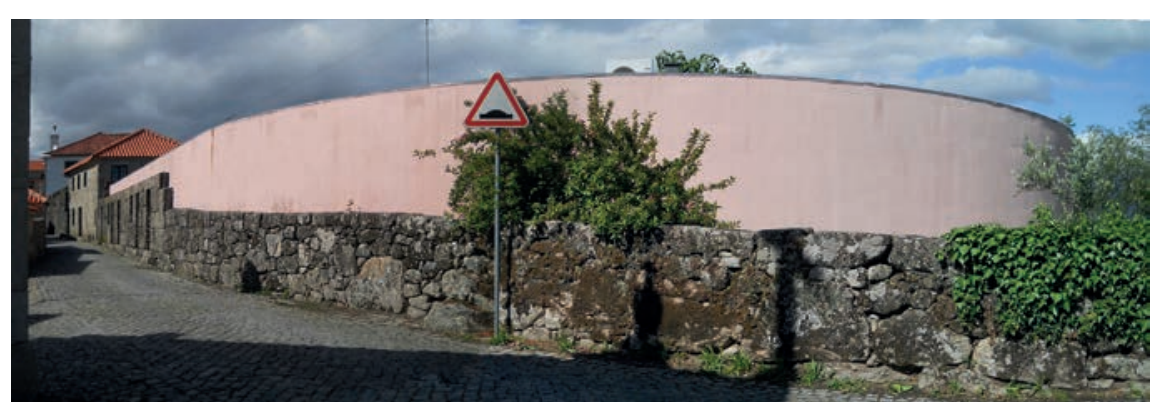

Fig. 9 - Gabinete de Investigação. Vista
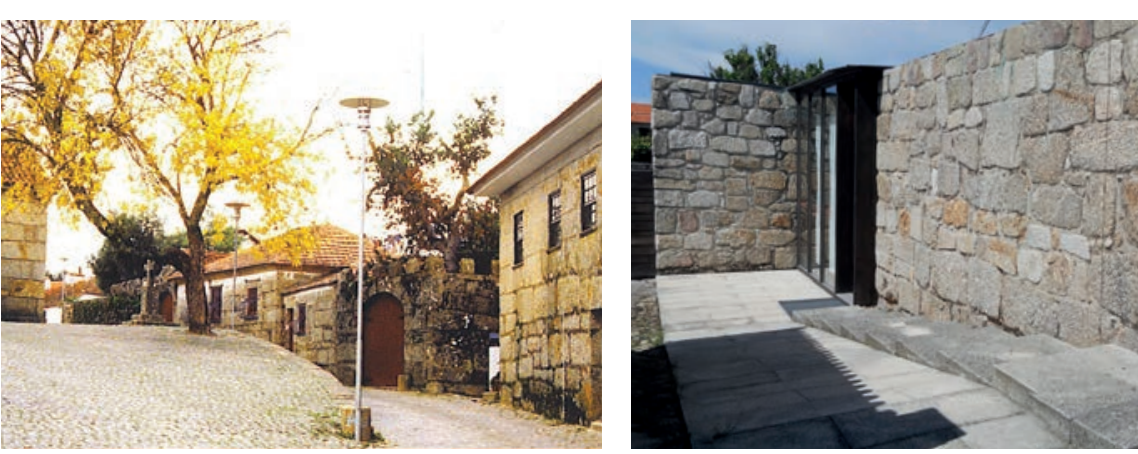

Fig. 10 - Escola Profissional de Arqueologia.

Fig. 11 - Auditório. Vista exterio

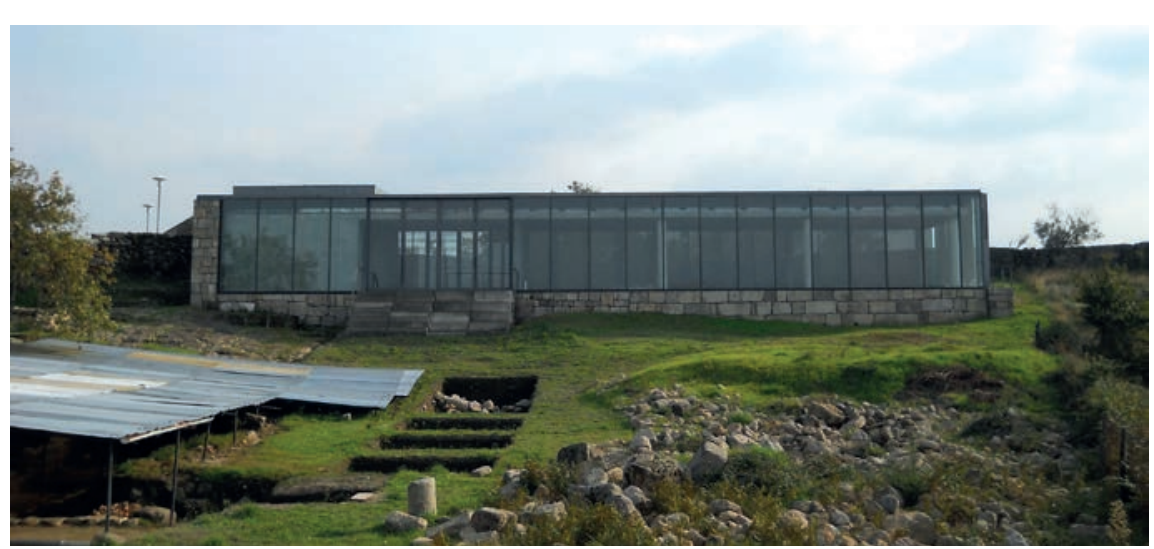

Fig. 12 - Núcleo de Vida Quotidiana. Vista

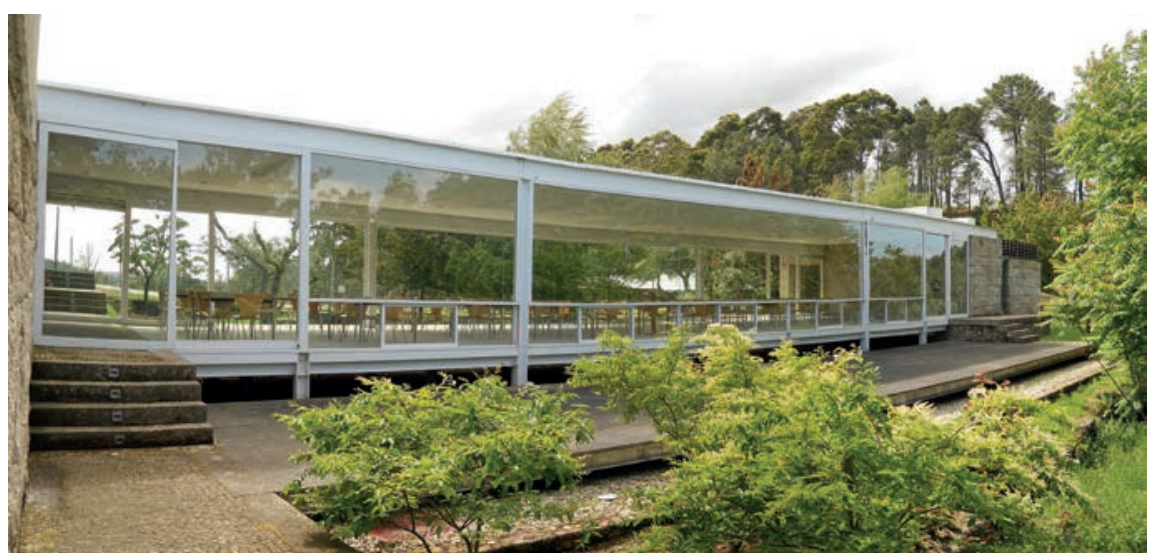

Fig. 13 - Restaurante e cafetaria. Vista

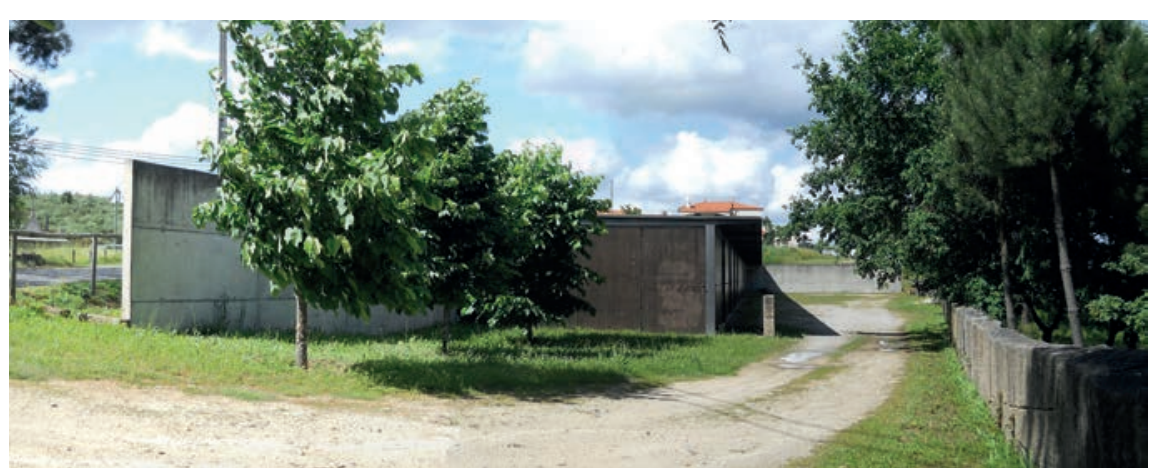
Fig. 14 - Núcleo de Apoio às escavações.
Vista exterior. 
Lino Tavares menciona também "(...) que os espaços patrimoniais devem ser, cada vez mais, espaços de consenso, cada vez mais espaços de bem-estar, que devem ser fruídos como locais de aprendizagem permanente ao longo da vida"16.

De maio de 1980 até aos dias de hoje decorreram 30 anos ao longo dos quais esta equipa se manteve trabalhando na exumação e compreensão do que era a cidade romana de Tongobriga. Desta cidade, apenas existem algumas referências documentais (destacam-se a referência de Plutomeu e a referência na "Divisão de Wamba" ${ }^{17}$ ), e, claro, a maior prova da sua existência, a própria ruína. Sendo que, aparentemente, não deixou outra "marca evidente"; só as escavações arqueológicas realizadas permitem aos investigadores reflectir sobre a reconstituição do traçado dos principais edifícios e perceber a estrutura geral da cidade (fig. 15).

Neste sentido, dispomos hoje de um conjunto de elementos desenhados e produzidos pelos investigadores, que catalogam, pedra a pedra, os vestígios das estruturas da cidade. E, desta forma, o que se conhece actualmente de Tongobriga, também um dos mais importantes povoados romanizados do Noroeste Peninsular ${ }^{18}$, é o fruto da investigação desta equipa, que aqui permaneceu na interpretação do vestígios resultantes de escavações sistemáticas, e que aqui, ainda hoje permanece ${ }^{19}$ (ver: Des. 1.01 e Des. 1.02).

${ }_{16}^{16}$ Lino Tavares Das, Tongobriga. Breves Reflexões, 2003, p. 82 . ${ }_{18}^{17}$ Idem, p. 14.

19 Lus Ferreira Caldo (texto introdutório), in Tongobriga, Lino Dias, 1997, p. 7.

pela Área Arqueológica do Freixo, e para alguns textos anteriores à investigaç̃ó e artín

gos de jornais que acompanharam as escavaç̃es, consultar em particular Tongobriga

Contributo Documental, onde estão textos referentes a Tongobriga até 1998.

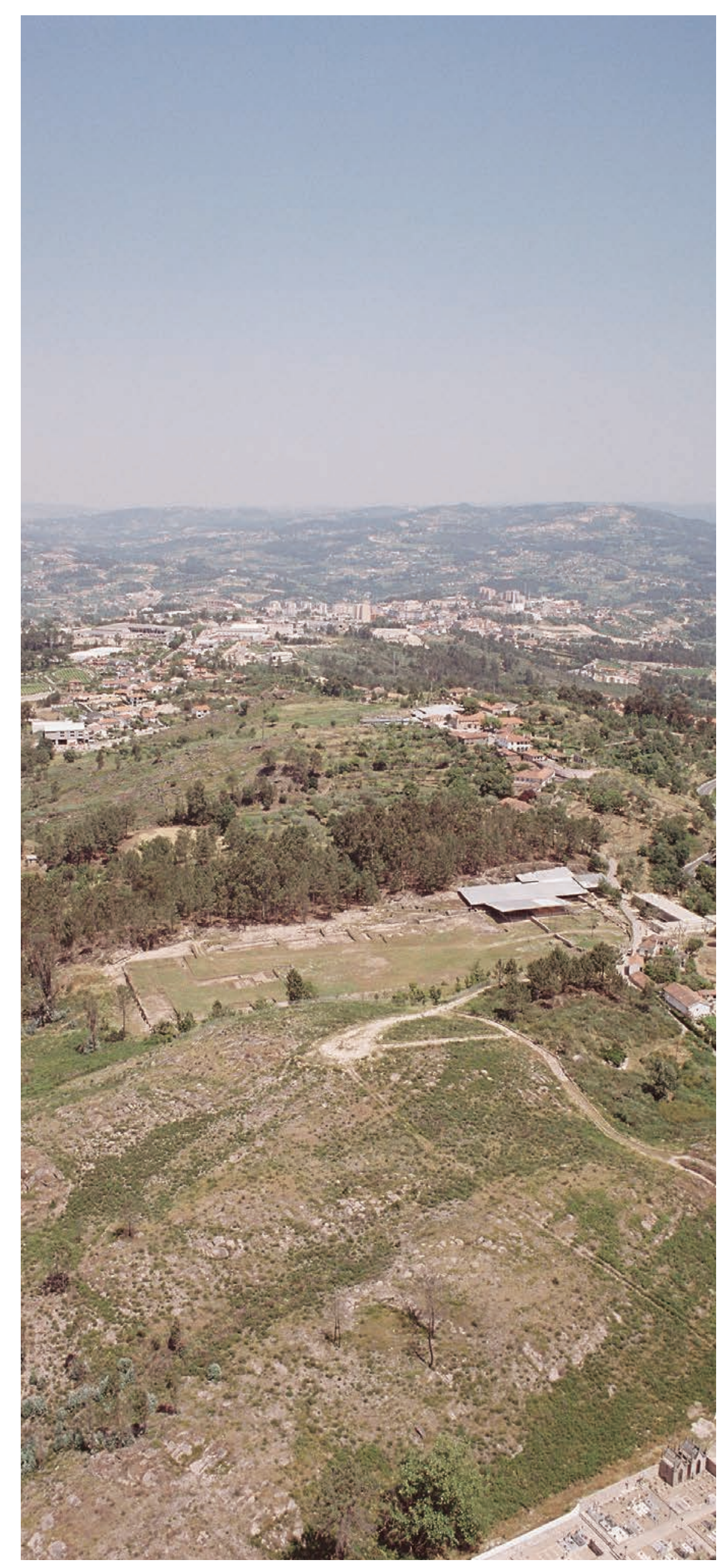

Fig. 15 - Área Arqueológica do Freixo e envolvente. Vista aérea. 


\section{2 - A Cidade}

1.2.1 - Origens, localização, território

Tongobriga, construída como cidade na periferia do Império Romano nos finais do século I d.C., é hoje interpretada como estrutura geoestratégica romana e também como centralidade e foco de cidadania ${ }^{1}$. Esta cidade, cujos vestígios confirmam uma ocupação romana até aos fins do século VII d.C., teve o seu auge na segunda metade do século II d.C., com a construção do Forum e os demais edifícios públicos, que a impuseram como centro de atracção e decisão. Após o seu posterior abandono e desintegração, esta área foi habitada na era medieval, e está hoje parcialmente ocupada pela pequena aldeia do Freixo.

Situada na zona norte do actual território português, e num território de conquista tardia para o Império Romano, Tongobriga pertencia à província Tarraconensis, cuja capital era Tarraco (Tarragona) (fig. 16). Na divisão em conventus, esta cidade integrava administrativamente aquele, que tinha sede na actual cidade Braga (Bracara Augusta), no conventus Bracara Augustanus (fig. 17).

O território tongobrigensium tinha fronteira com três elementos naturais de grande presença na paisagem, que conformavam entre si um triângulo territorial. A norte e nascente, o território confrontava com a Serra do Marão, cujo ponto mais elevado tem $1415 \mathrm{~m}$; a noroeste e sul, este propagava-se por uma região de colinas e serras, até encontrar os rios Tâmega e Douro, respectivamente. Estes dois rios teriam grande importância no transporte de produtos e no comércio para esta região, permitindo assim uma maior facilidade no transporte de cargas pesadas² (figs. 19 e 20).

A cidade de Tongobriga integrava uma estrutura viária de interesse interprovincial, designadamente uma estrada que ligava duas capitais, Braga (Bracara Augusta) e Mérida (Emerita Augusta), notoriamente uma via estratégica que circulava pelo interior do actual território português. Tongobriga estaria ligada à cidade de Braga por uma estrada que saía pela porta norte da cidade, em direcção a uma ponte ${ }^{3}$ que existia sobre o Rio Tâmega (a noroeste). A ligação a Mérida, através da travessia do Douro, seria feita no actual Porto Manso e em Aregos (fig. 18).

${ }^{1}$ Referência de Lino Dias, durante o Ciclo de Conferências - Leituras Contemporâneas que tongobriga propicia, 2010

33

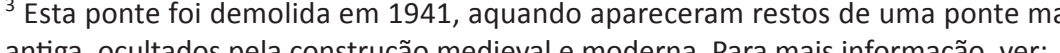
http://www.monumentos.pt/Site/APP_PagesUser/SIPA.aspx?id=4930.

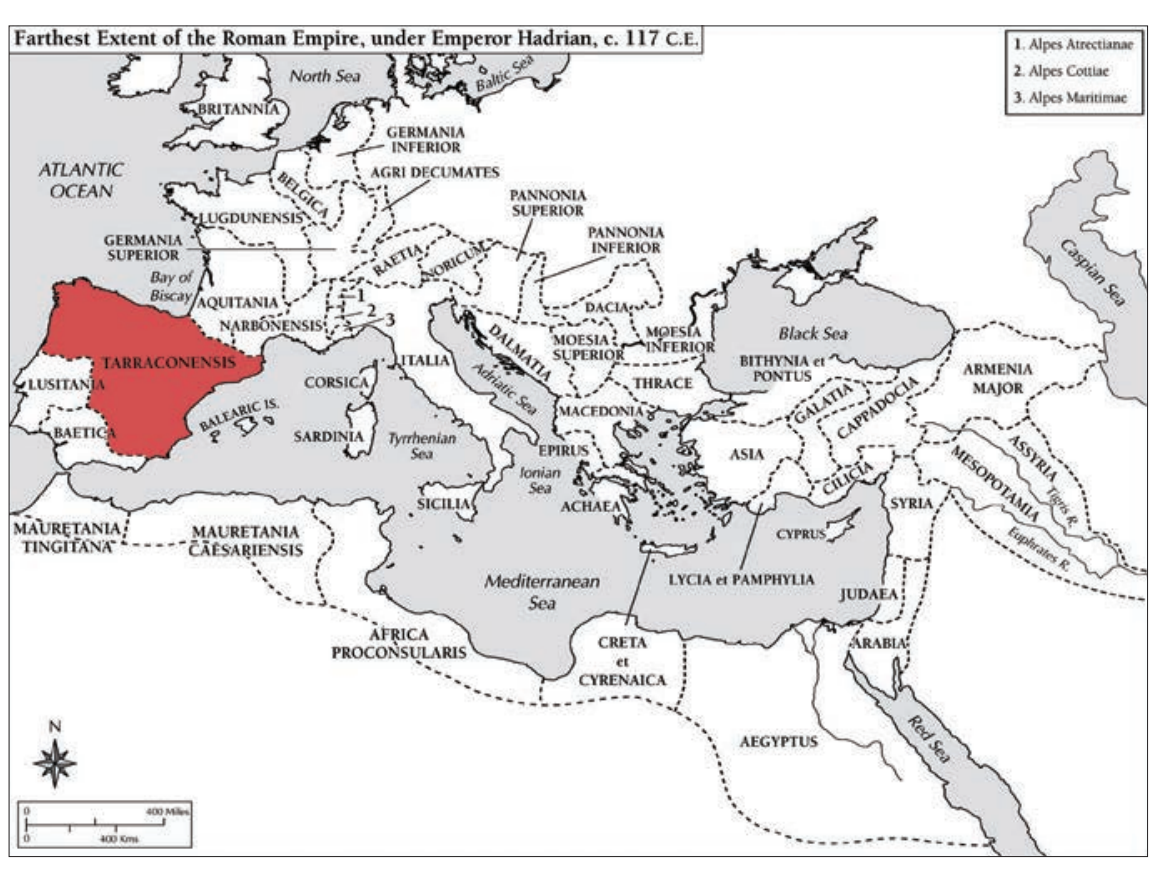

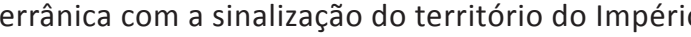
Romano. A vermelho destaca-se a província Tarraconensis.
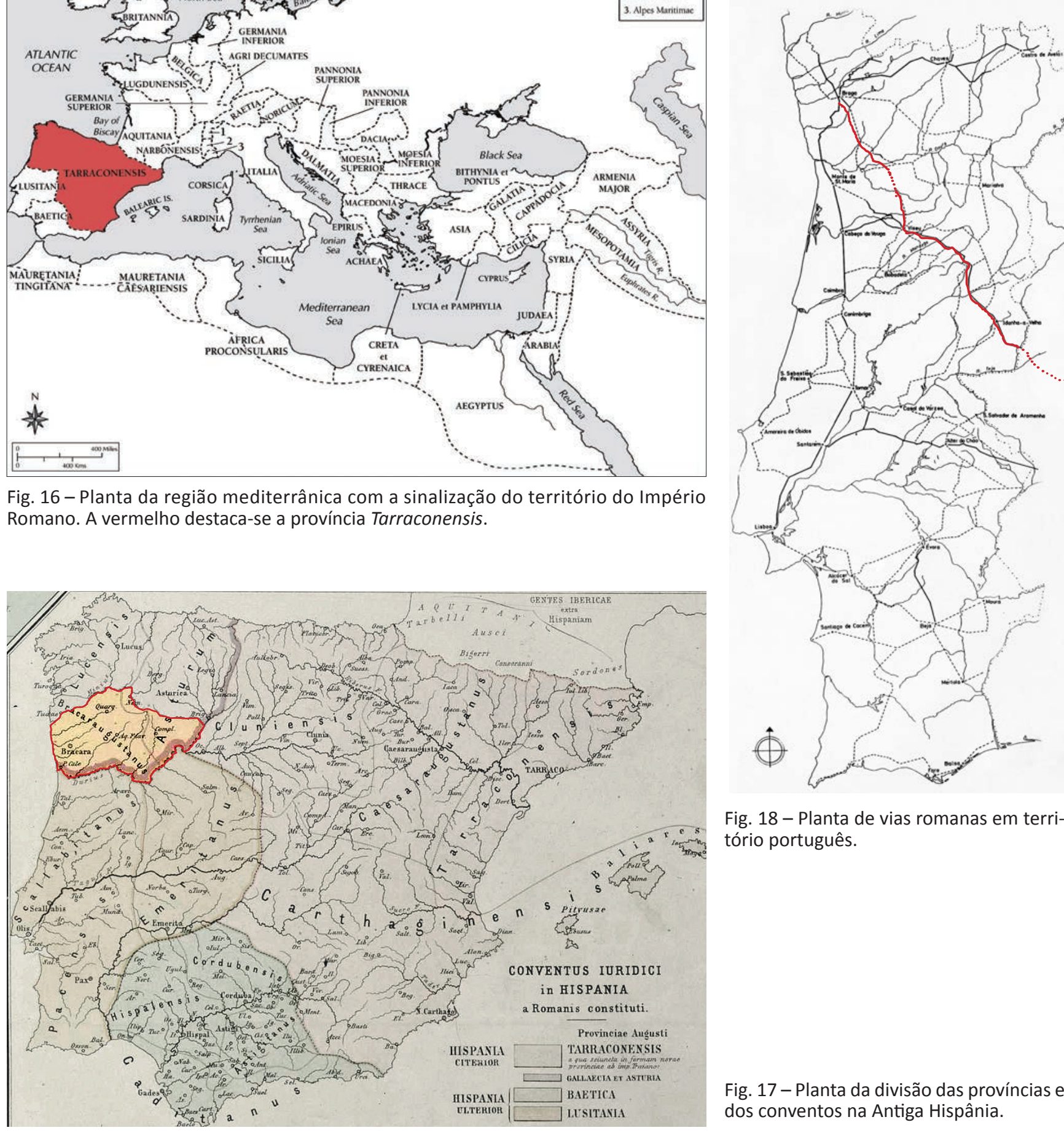

Fig. 18 - Planta
tório português.

Fig. 17- Planta da divisão das províncias e dos conventos na Antiga Hispânia.

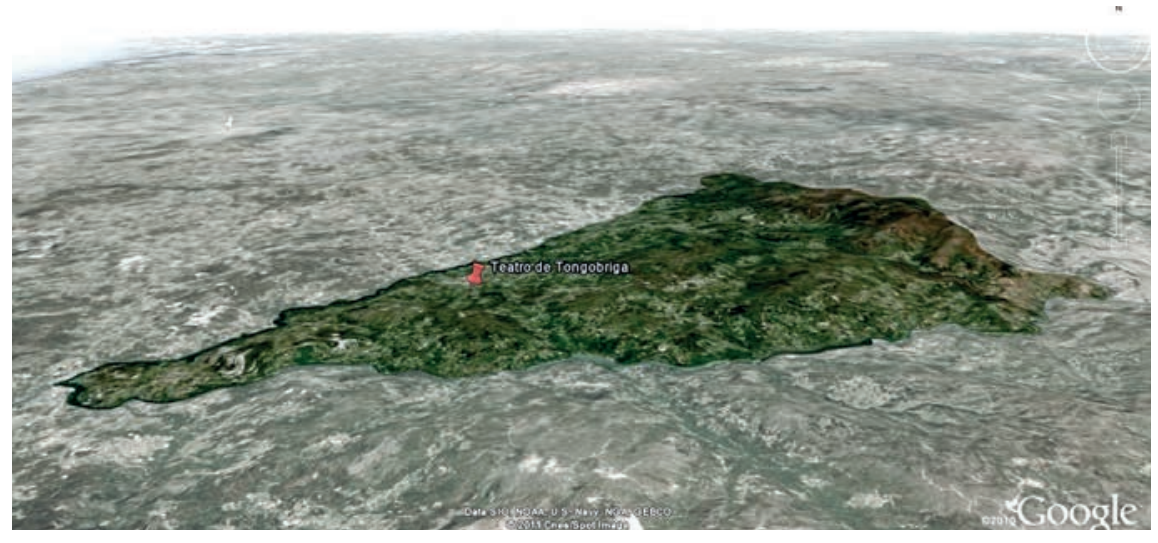

Fig. 19 - Espaço correspondente à cidade de Tongobriga. Vista aérea.

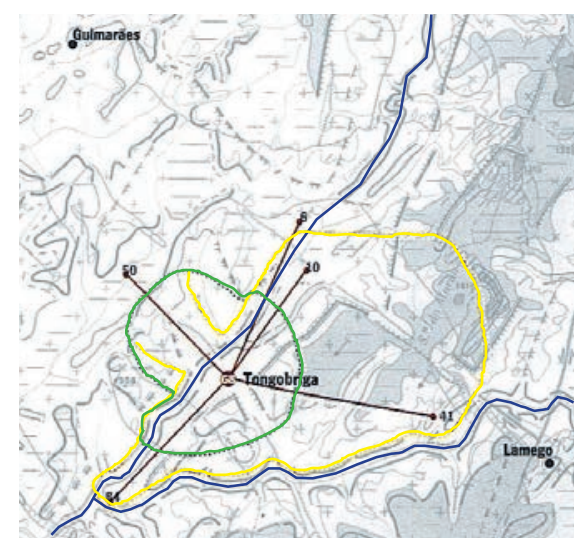

Fig. 20 - Planta do território de Tongobriga. 
O topónimo Tongobriga foi o adoptado entre diferentes formas de escrever a mesma palavra e o seu significado reparte-se no seu nome ${ }^{4}$. A definição do sufixo -briga aponta para a existência de um povoado assente num ponto saliente, uma terminação bastante vulgar no ocidente da antiga Hispânia. Quanto à raiz Tong-, de origem céltica, tinha o significado de "união" ou "juramento"

Estavam aqui reunidas as condições ideais para a fundação de uma cidade romana. Apesar do relevo acentuado dificultar a implantação da cidade (fig. 21), esta localização proporcionava diversas condições favoráveis. Devido à sua posição num alto, longe de qualquer pântano ou lagoa ${ }^{6}$, esta localização propiciava uma fácil defesa do povoado, facilitava o escoamento da rede de esgotos, e encontrava-se envolvida por terrenos férteis ${ }^{7}$ e boas pedreiras, que permitiram a extracção de matéria-prima para a construção dos edifícios, e que asseguravam as fundações das estruturas. A nível climático, esta localização proporcionava a protecção de neblinas ${ }^{8}$, a abundância de nascentes de água e a proximidade de rios, apesar de um pouco distantes, tal como o Rio Tâmega, que teria um porto que servia certamente a cidade ${ }^{9}$.

4 "Tongobria, Tuntobriga, Tontobriga, Tongobriga são, no nosso entender, versões differentes de escrever a mesma palaura e, neste caso, referem a cidade citada por Ptolomeu e que surge tambem no texto de Wamba. Optámos pelo Tongobriga, e identificamos esta cidade com o actual l ugar do Freixo, onde as evidencias arqueologicas confirmam a propriedade da inscrição encontrada em 1882". Lino Dias, Tongobriga. Breves Reflexões, 2003, p. 15.
5 M. Lapesa, La O O

Cesconal La Onomástica Personal Prina de la Antigua Lusitania, 1957, p. 104.

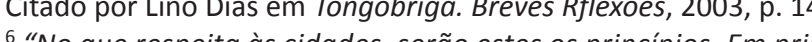

lugar, a eleição Vitrúvio, I, 4, 1. Tradução de Justino Maciel.

7 "Quando, pois, segundo estas regras, se verificar o requisito da salubridade dos recintos urbanos a levantar, forem escolhidas regiōes abundantes em frutos para alimentar a cidade (...)" Vitrúvio, I, 5, 1. Tradução de Justino Maciel.

"Quanto à qualidade dos solos, no Portugal Antigo e Moderno publicado em 1880, Pinho Leal dizia que no Freixo a terra era fértil. No entanto, em 1914 Manuel da Vasconcelos

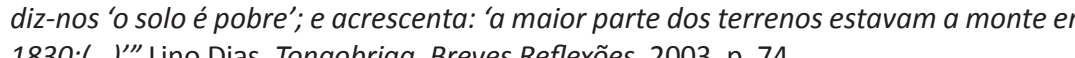

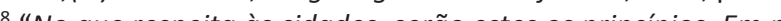

de um lugar o mais saudével possivel. Este será alto e ñ̃o nebulose voltado para o quadrante que nõo seja nem quente nem frio, mas temperado ( efeito, quando as brisas matutinas, ao nasce nascidas se juntarem a elas, tornarão o lugar pestilento, espargindo com o seu influxo, misturadas com a névoa, os miasmas envenenados dos animais palustres nos copos dos moradores. (...)" Vitruvivio, I, 4, 1. Tradução de Justino Maciel.

Há ainda as particularidades de (Tongobriga) quase não ter neblinas e nevoeiros, mesmo quando eles cobrem toda a região envolvente e, em relação a essa mesma

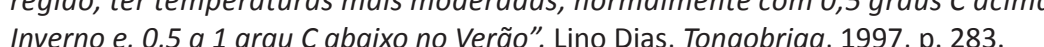
9 "Quando, pois, segundo estas rearas, se verificar (.), localizacôes favoráveis de rios of comunicacões marítimas através de um porto proporcionarem facilidades de transpor tes para as cidades, (...)" Vitrúvio, I, 5, 1. Tradução de Justino Maciel.
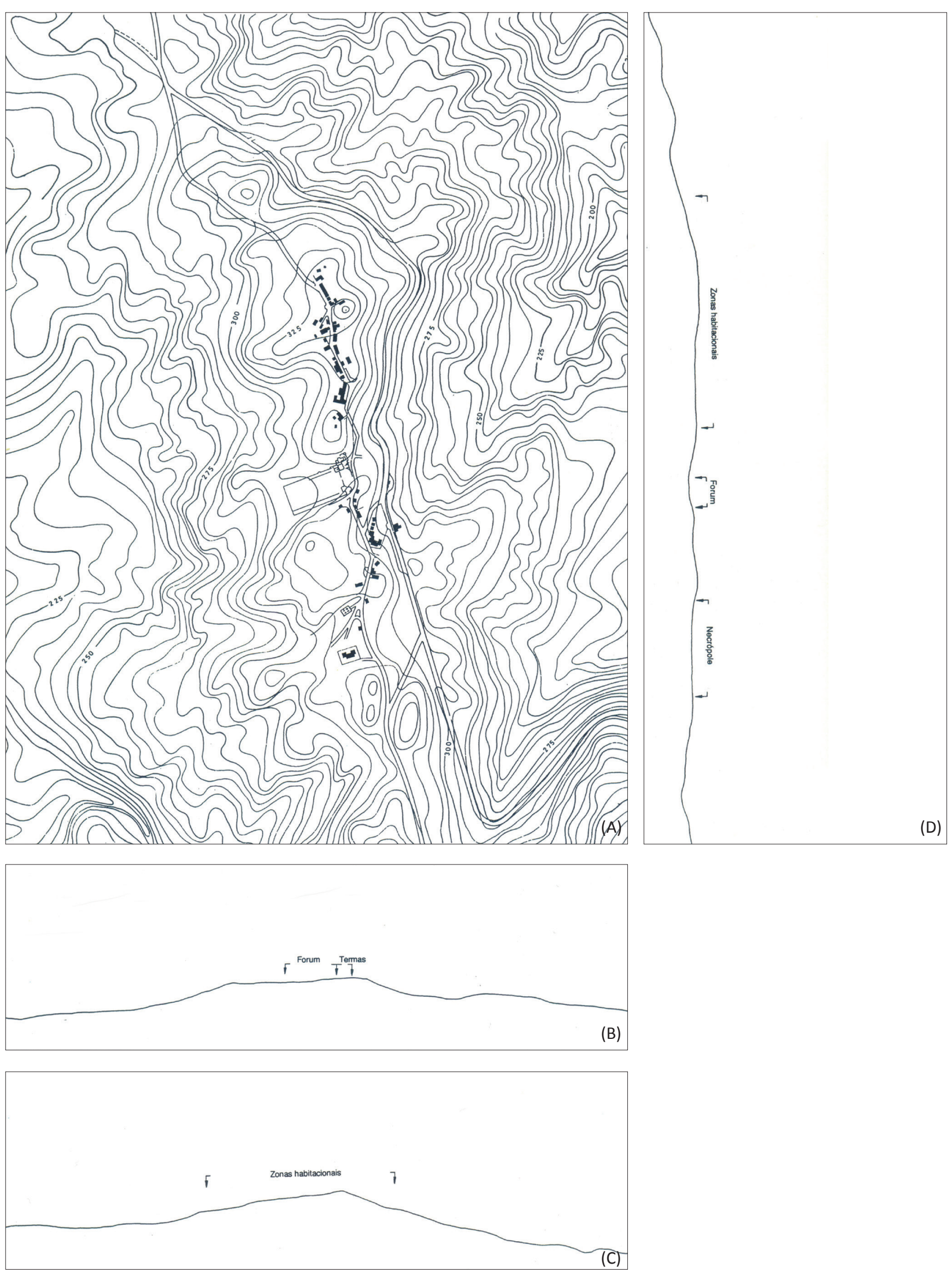

Fig. 21 - Representação da morfologia do terreno em Tongobriga.

(A) - Planta

A) - Perfil transversal, espaço das termas e forum

(D) - Perfil longitudinal, áreas habitacionais, forum e necrópole
(D) 


\subsection{2 - Urbanismo e organização}

A implantação de uma cidade romana provincial era uma arma de aculturação muito poderosa. A nova cidade seria uma forma de glorificar a "capital do império", imitando-a nos seus melhores aspectos ${ }^{10}$ A cidade vinha não só impor uma nova forma de habitat, como transformava radicalmente a organização política e social da região, assim como o modo de vida quotidiano.

No desenho da cidade, os romanos eram defensores de princípios de ortogonalidade. Defendiam que uma cidade bem planead estaria disposta segundo uma grelha, e organizada segundo uma disposição regular, de ruas e quarteirões, onde se integrariam as habitações e os edifícios públicos. Mas tal sistema só podia ser aplicado sobre terrenos totalmente livres e sem acidentes morfológicos.

Assim como em muitas outras cidades do império ${ }^{11}$, o relevo acidentado que se faz sentir em Tongobriga não terá facilitado a plena "regularidade" do traçado de arruamentos ortogonais. Os planeadores encarregues da implantação desta cidade teriam que fazer alguns ajustes no sistema hipodâmico tradicional, de modo a adaptá-lo ao terreno (fig. 22)

No traçar destes arruamentos, os romanos tinham em conta a direcção dos principais ventos. Segundo Vitrúvio, a orientação idea para a cidade seria numa orientação entre o eixo dos ventos Aquilo/ Africus e do eixo Solanus/Favonius ${ }^{12}$, o que correspondia a um ângulo de 22,5\% em relação aos principais pontos cardiais (fig. 25).

Ora, numa situação como em Tongobriga, em que a cidad era construída sobre relevo acentuado, de pouco valia a orientação de ruas para o desvio do vento nas fachadas ${ }^{13}$; pois, neste caso, os montes

${ }^{10}$ David Macaulay, no Documentário "Roman City", 1994.

${ }^{11}$ Exemplos de cidades cuja morfologia do terreno foi um obstáculo na sua implantação: Bilbilis (fig. 23), Tarraco (fig. 24).

12 "Tendo como referência estas duas marcas, descrever-se-á com o compasso uma interseçção de circulos secantes, traçando-se uma linha recta que passa por esse crue setentrional Depois disso, tomar-se-á a décima sexta parte da totalidade da linha do circulo e marcar-se-á o centro da rotacão no ponto em que a linha meridiana toca o círculo, fazendo também marcas à direita è esquerda sobre o mesmo círculo, seja da parte setentrional. Então, a partir destes quatro pontos, e de uma extremidade à outra do dito círculo, traçar-se-ão linhas que se intersectam no centro. Assim se encontrard a designação da oitava parte, uma do lado do austro; outra, do lado do setentriáa. As restantes partes deverão ser distribuidas de modo igual na totalidade do circulo, trés para a direita e trés para a esquerda, para que na descrição sejam designadas, en partes iguais, as divisoes dos oito ventos. Deste modo, nos parece que o ordenamento das praças e das vielas devera ser alinhado pelos angulos entre duas direcçōes de

cões e das ruas a forca nociva dos ventos. Se, efectivamente, tamente expostas a eles, o impeto vindo do espaco aberto do péu e a brica constante

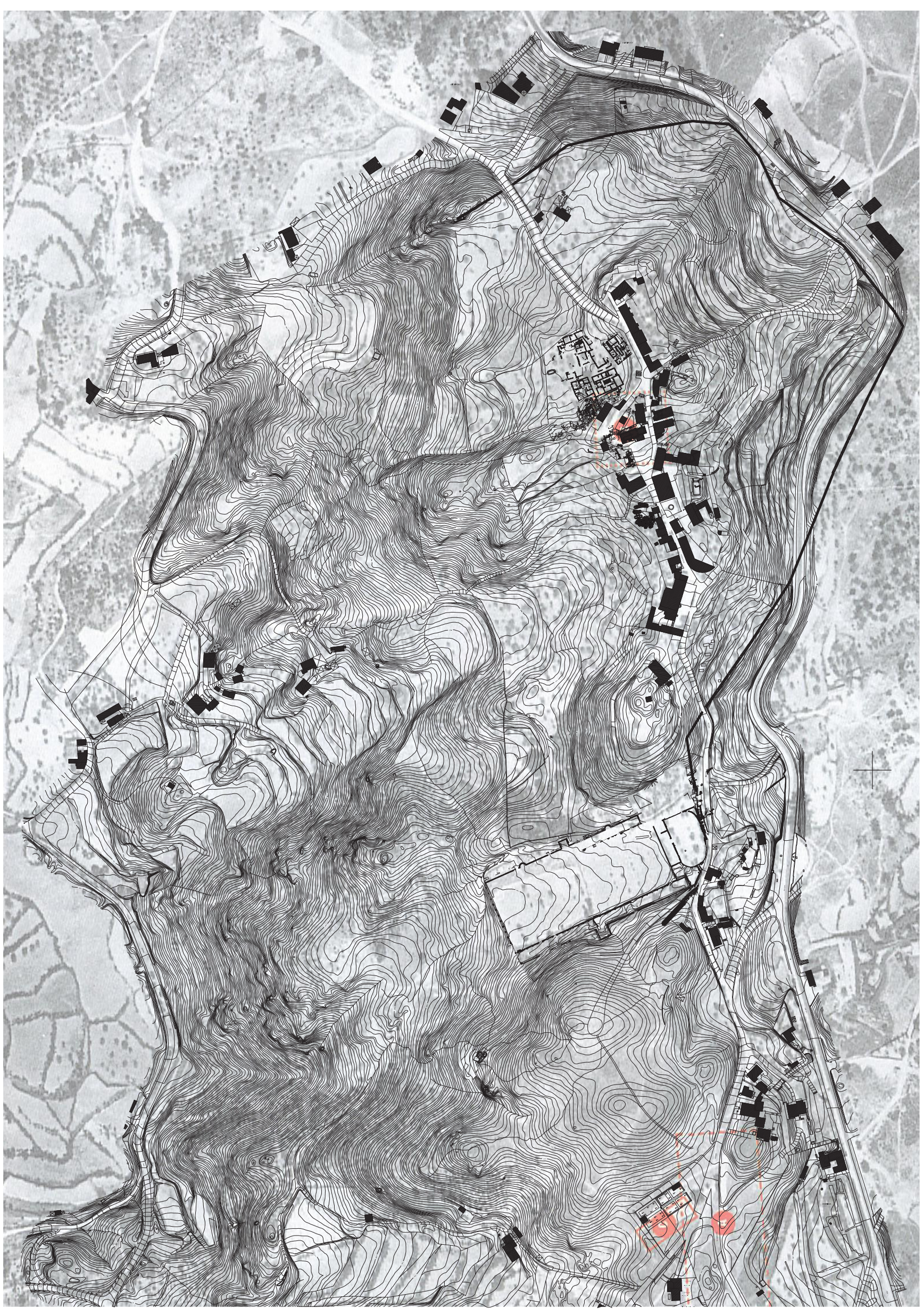

Fig. 22 - Sobreposição do Levantamento Aerofotogramétrico de 2009 sobre fotografia aérea, voo SPLAL 38. (Fiada b, fotografia 722, Secção da Fotografia Cartográfica do Instituto Geográfico do Exército). 
teriam um maior papel em amparar os ventos nocivos. Mesmo assim verificando em imagens aéreas e no levantamento aerofotogramétrico, todos os vestígios das estruturas romanas forum, termas, habitações, muros soltos, a própria topografia) têm a mesma orientação, uma tendência direccional que ronda os $24^{\circ}$ em relação ao eixo $\mathrm{E} / \mathrm{O}(\mathrm{N} / \mathrm{S})$, o que corresponde aos preceitos de Vitrúvio.

Para além da preocupação com os ventos, hábito dos romanos principalmente em cidades planas, em Tongobriga, a precipitação terá sido outro factor de preocupação, principalmente na protecção de entradas e escoamento das ruas, por forma a evitar enxurradas ${ }^{14}$.

Uma vez traçados os arruamentos, os romanos procuravam construir os seus edifícios públicos no centro da urbanização, junto a um forum ${ }^{15}$. Estes representariam a sua cultura, a sua religião, a sua forma de viver o dia a dia. A questão é que, no caso de Tongobriga, tal localização não foi possível, pois, dadas as dificuldades causadas, mais uma vez pela morfologia local, houve a necessidade de expandir o espaço urbano, e implementar o centro cívico (termas, forum, basílica templo e demais edifícios públicos), na extremidade sul do limite da cidade. Esta terá sido a melhor solução, por forma a seguir o "principio de oportunidade" defendido por Vitrúvio.

Completando estes elementos, a observação da fotografia aérea de Tongobriga permite aos investigadores supor um traçado do Cardo máximo como espinha dorsal da cidade ${ }^{16}$, que estruturaria toda a urbanização a partir dos decumani (apesar de ainda não ter sido possíve determinar uma decumanos maximo)

O percurso do cardo e a organização da cidade foi descrito em 1995, por Lino Dias, da seguinte forma (figs. 26, 27 e 28):

contida na entrada estreita das vielas andarão por aqui e por ali com uma veemência mais forte. Eis porque não se deverão voltar para as orientaç̃̃es dos ventos os direccionamentos das ruas, de modo que, ao chegarem, eles se enfraqueçam contra os ângu${ }_{14}$ "Circundado o recinto, sequir-se-ão as diviviões das áreas dentro da muralha eas orie taç̃es das praças e das ruas. Serão, de facto, traçados como deve ser se habilmente se afastarem das ruas os ventos que, se forem frios, prejudicam, se quentes, corrompem, $s$. húmidos, são nocivos. Por esta razão julga-se que se deverá evitar este condicionalismo e precaver para que não se verifique o que costuma acontecer em muitas cidades, como em Mitilen, opido na ilha de Lebos edificado de modo magnificente e elegante, mas estabelecido sem habilidade. Quando esta cidade sopra austro, os homens adoecem; soprando o coro, tossem; quando o setentrião, são restituidos a saude mas não poder permanecer nas ruas nem nas praças, devido à veemência do frio". Vitruvio I, 6, 1. Tra 15 "se o Jecinto fortificad

deverá ser escolhida pro se encontrar junto ao mar, a zona onde se implantará o foro devera ser escollda prón ${ }^{16}$ Ver Tongobriga, Lino Dias, 1997, p. 30.

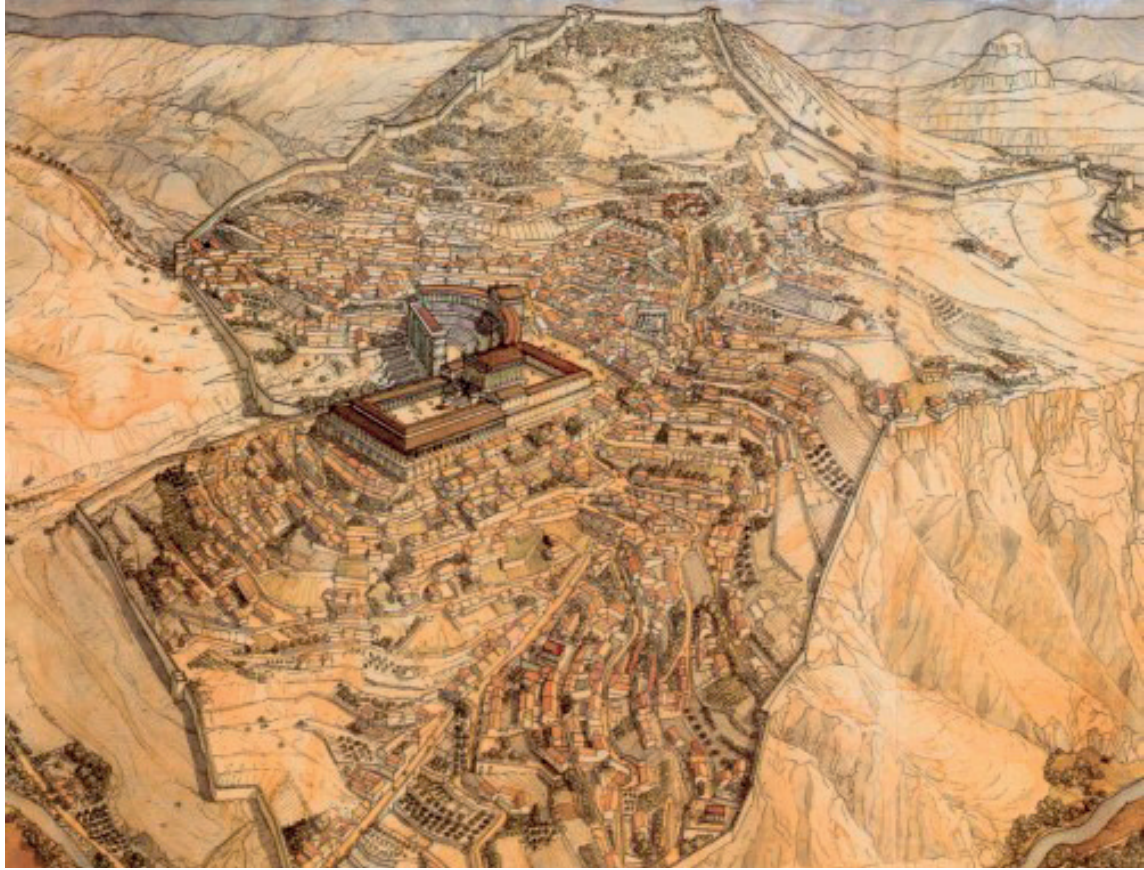

ig. 23 - Ilustração da cidade romana de Bibbilis, por Jean-Claude Gouvin. Nesta imagem relevante a atenção sobre a forma como o conjunto de equip topografia local.

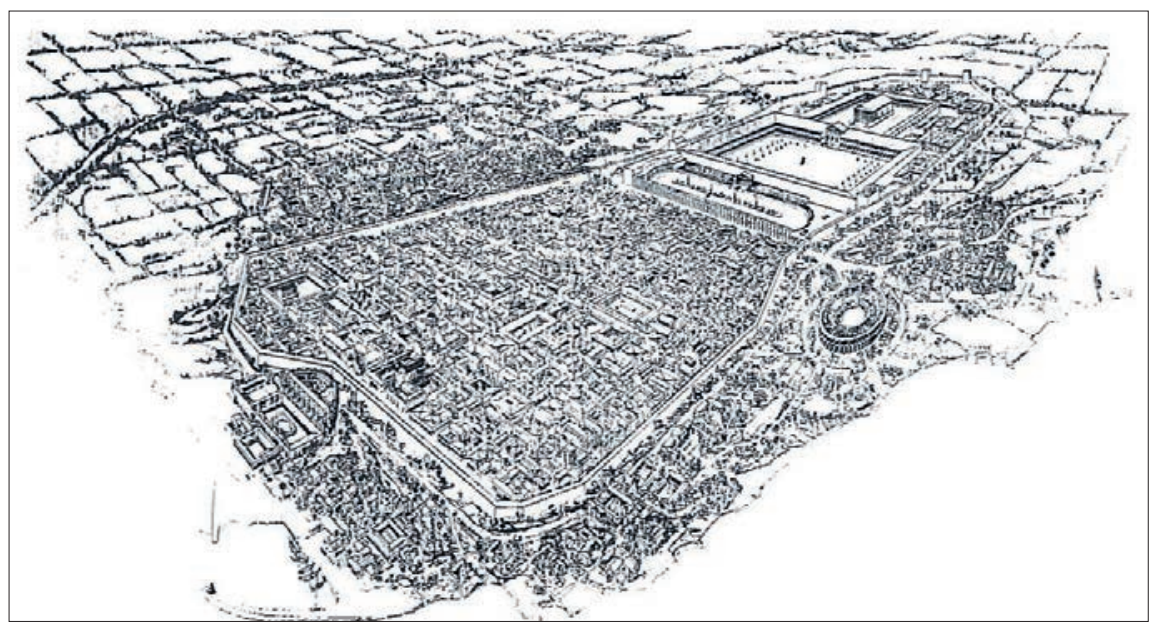

Fig. 24 - Ilustração da cidade de Tarraco, por F. Terrais.

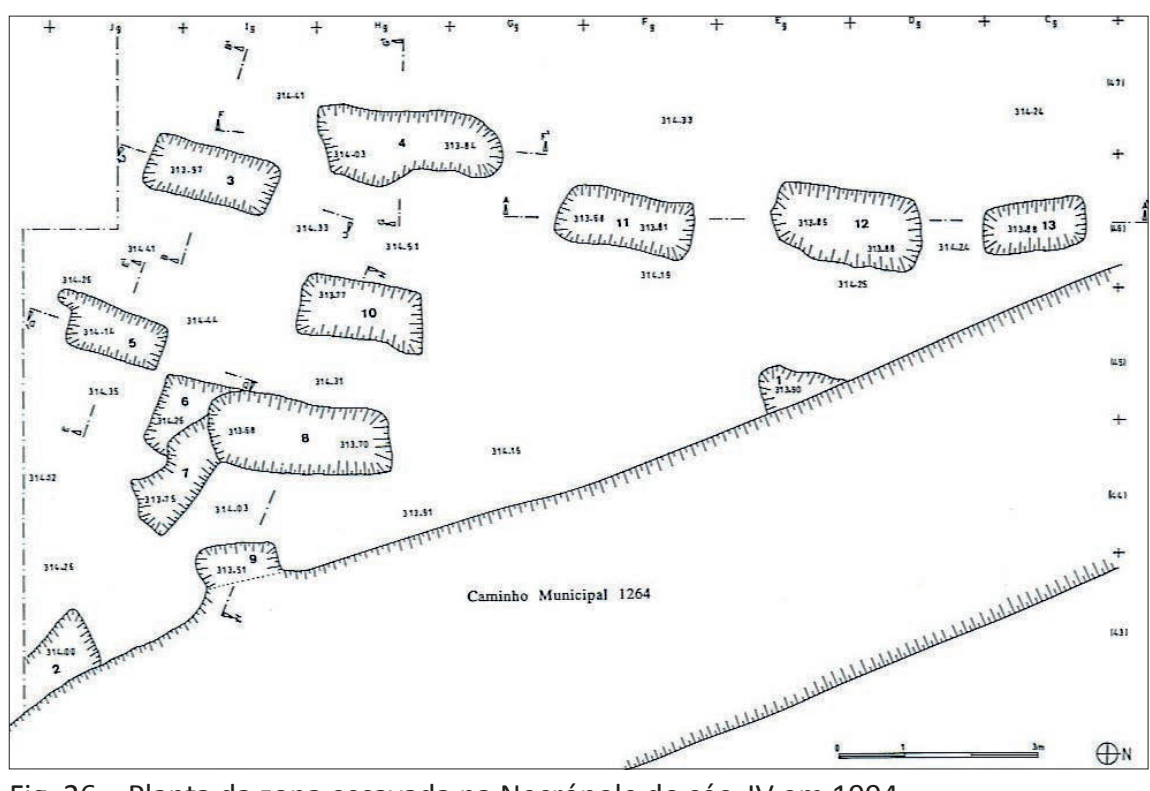

fig. 26 - Planta da zona escavada na Neciopole do séc. IV em 1994.

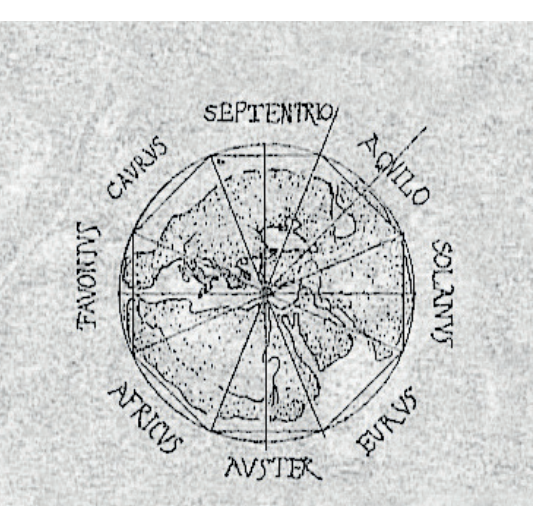

(A)

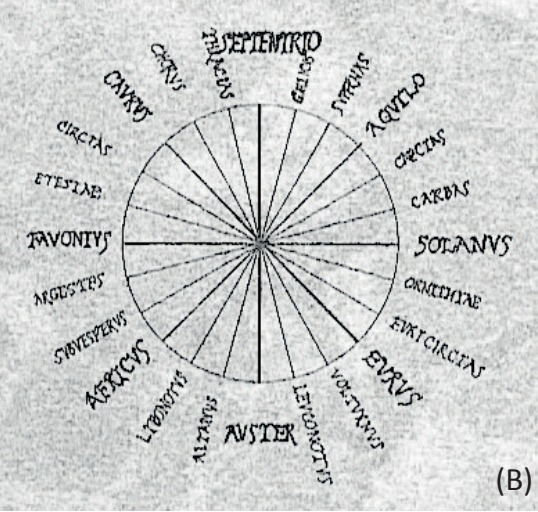

25 - Representação da rosa-dos-ventos segundo Vitrúvio

(A) - Vitrúvio I.6.7 e I.6.13, com oito ventos, ocupando cada 3937000 passos da "circunferência do globo terrestre" Eratóstenes). (B) - Vitrúvio 1.6 .10
nais intermédios.

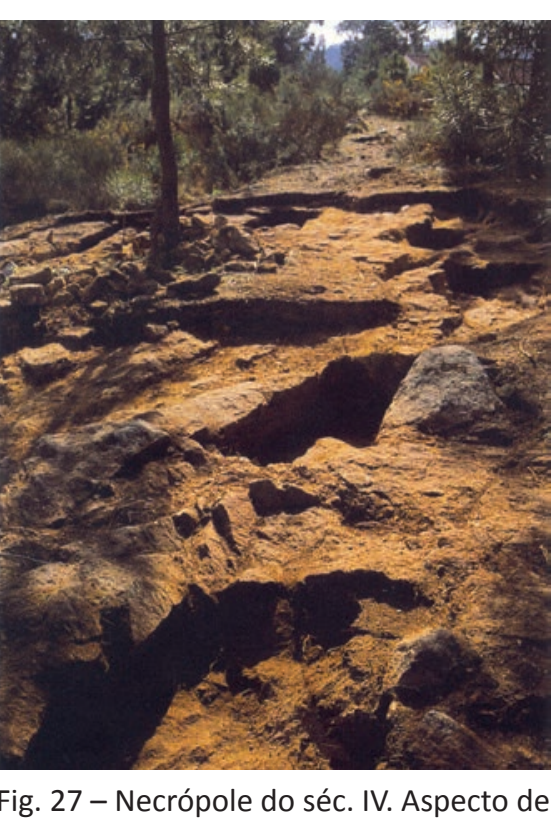

Fig. 27 - Necrópole do séc. IV. Aspecto de uma zona escavada. 
"O traçado do cardo, depois de atravessar a necrópole (1), era marcado pela entrada na cidade (2). Desta restam tão só marcas bem vincadas nos afloramentos graníticos, embora não permitam dizer que tipo de estrutura ali existia. Quem por aqui entrava, deparava com uma pequena elevação granítica, pelo que só depois de ultrapassada era possivel entrar no forum pelo lado sul. Via, então, um vasto e amplo espaço, a praça (3). À direita, situava-se a basílica (4) e, em segundo plano, as termas (5). À esquerda, a oeste, o espaço religioso (6).

Atravessado o forum segundo o seu eixo menor, caminhava-se sem esforço no cardo ao longo dos cerca de 1000 metros de comprimento, já que foi traçado sempre entre os $312 \mathrm{~m}$ e os $320 \mathrm{~m}$ de altitude, e a subida, apesar de ligeira, só se fazia a partir do espaço onde se situaria o teatro (7). (...)

O cardo atravessava as zonas habitacionais (8). A saída da cidade, para norte, far-se-ia depois de atravessar um fosso natural (9) que limitava o espaço urbano. A hipótese de existir outra necrópole nesta saída da cidade não se confirmou até ao momento.

A estrada seguia depois em direcção à ponte sobre o rio Tâmega Canaveses (foto aérea, esc. 1/15000 sob acetato n. o 3). Junto desta entrada, e a partir da observação de fotografia aérea (esc. 1/4000), podemos observar uma estrutura que identificamos como circo (10) (...). Situava-se já um pouco para nordeste e, como dissemos, era servido pela mesma estrada que ligava Tongobriga à ponte sobre o Tâmega, em Canaveses. (...) $)^{\prime 17}$.

Tendo estes princípios como base, e a organização citada entende-se que Tongobriga foi implantada por forma a adaptar-se ao terreno; constituída pelos edifícios públicos e privados, que privilegiaram, sobretudo, a encosta poente, face à nascente.

Esta cidade procurou seguir os modelos e noções romanas da melhor forma possível, apesar das dificuldades com que os romanos se depararam. Demonstra-se aqui uma capacidade técnica e cultural de adaptação, assim como uma grande sabedoria e determinação pela escolha do lugar para se instalar esta urb, a cidade romana de Tongobriga.

${ }^{7}$ Lino Dias, Tongobriga, 1997, pp. 30-31.

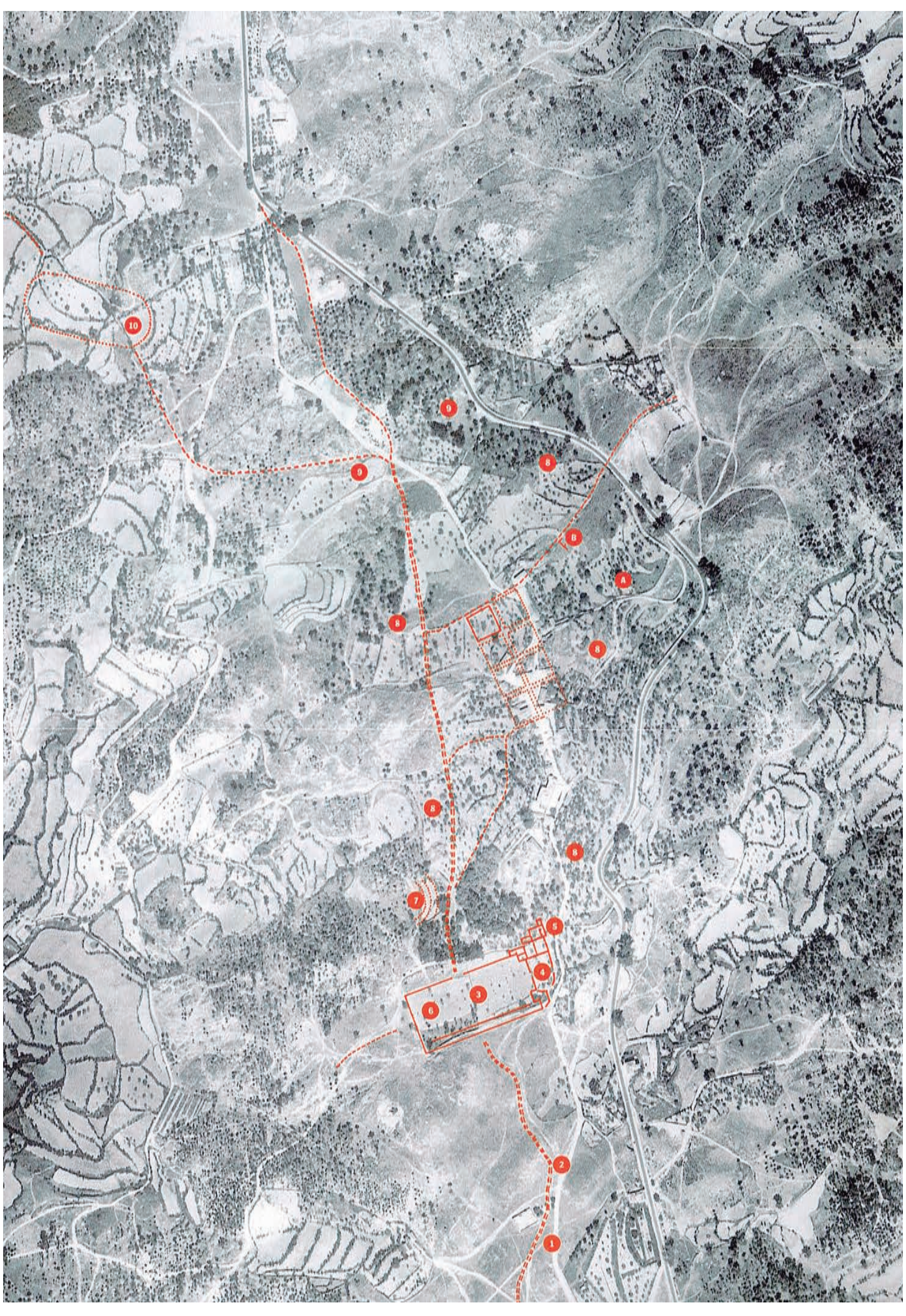

Fig. 28 - Urbanismo, a organização e percurso da cidade sobre fotografia aérea. 


\subsection{3- Muralha}

Pela sua presença física ou significado espiritual, a muralha romana era, em alguns casos, apenas uma linha de defesa, e noutros casos uma linha de separação simbólica, "entre ordem e desordem, entre cultura e caos"118. Tal diferença depende muito de cada cidade e do ano da sua construção, pois cidades do alto império não teriam a defesa da cidade como principal critério.

A cidade de Tongobriga foi certamente delimitada. A existência da muralha é cada vez mais comprovada pelo traçado de muros articulados com afloramentos graníticos e escarpas naturais, que criavam o "limite honorífico" da cidade ${ }^{19}$. Segundo os vestígios existentes, é possível determinar que este espaço urbano teve duas fases amuraIhadas (fig. 29) ${ }^{20}$

Numa primeira fase $\mathrm{e}^{21}$, contemporânea às habitações de planta circular e ao balneário castrejo, o espaço urbano era delimitado por uma muralha com cerca de 1400 metros de extensão, protegendo uma área habitacional de 13,5 hectares. A muralha circunscreveria uma área acima dos 300 metros de altitude, o que permitia ter um amplo horizonte visual sobre a envolvência ${ }^{22}$. Em todo o seu redor, a muraIha estaria construída sobre taludes, maciços rochosos e declives de terreno, por forma a garantir as suas fundaçõe ${ }^{23} \mathrm{e}$ a protecção do oppidum (fig. 30, 31 e 32).

Um eixo viário principal atravessaria a urbanização, marcando assim duas portas. Na intersecção a norte com a muralha estaria localizada uma porta principal de entrada na cidade, que aproveitou uma depressão no terreno (fig. 33). Com a ajuda de um fosso natural que ali existia, a muralha delimitaria a cidade. A sul, entre um alto, a
${ }^{18}$ David Macaulay, no documentário "Roman City", 1994.

${ }_{20}^{19}$ Lino Dias, Tongobriga. Breves Reflexões, 2003, p. 18.

${ }^{20} \mathrm{~A}$ reconstituição do perímetro amuralhado baseia-se em dados proporcionados po escavaçōes (direç̧ão científica do Doutor Lino Tavares Dias e do Prof. Rudolf Winkes) Ihos arqueológicos de 2004 e 2005. ${ }^{21}$ Consultar Des. 104 .

${ }_{22}$ "Sem ser dos sitios mais altos na região, Tongobriga tem uma localização que facilita um amplo horizonte visual sobre a envolvência e é, simultaneamente, ponto de referência visual". Lino Dias, Tongobriga, 1997, p. 283.

${ }_{23}$ "Quando, pois, segundo estas regras, se verificar o requisito da salubridade dos recintos urbanos a levantar, forem escolhidas regiôes abundantes em frutos para alimentar a cidade, quando construções de vias, localizaçôes favoráveis de rios ou comunicações maritimas atraves de um porto proporcionarem facilidades de transporte para as cidades, do seguinte modo deveráo ser construidos, então, os fundamentos das torres chão firme, até onde pareça ser necessário segundo a amplitude da obra, com uma espessura mais larga do que a das paredes que ficarão acima da terra, enchendo-se de concreto o mais consistente possivel". Vitrúvio, I, 5, 1. Tradução de Justino Maciel.

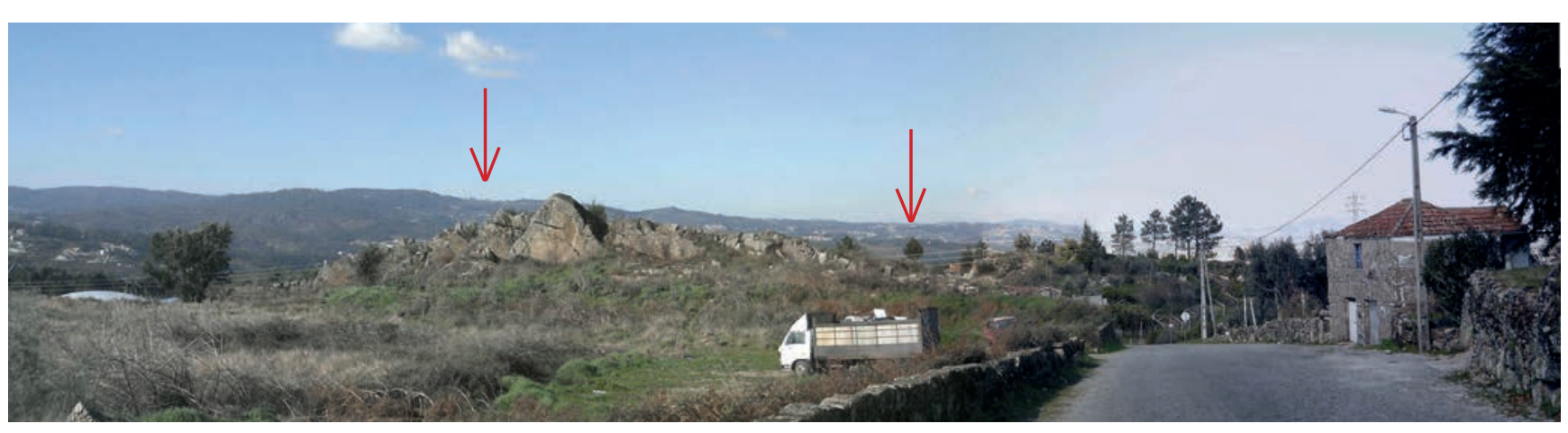

Fig. 30 - Afloramento granítico que terá servido de suporte a um troço de muralha. Limite norte, junto ao ponto de entrada na

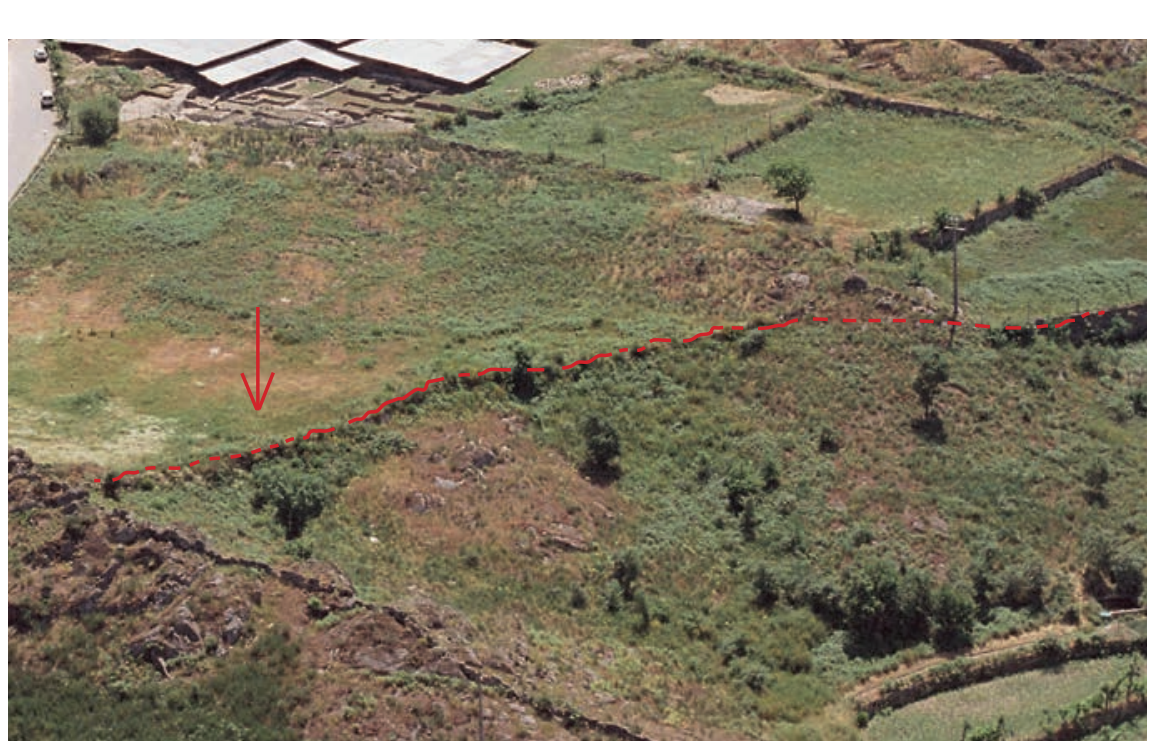

Fig. 31 - Troço de muralha poente. Junto ao conjunto habitacional.
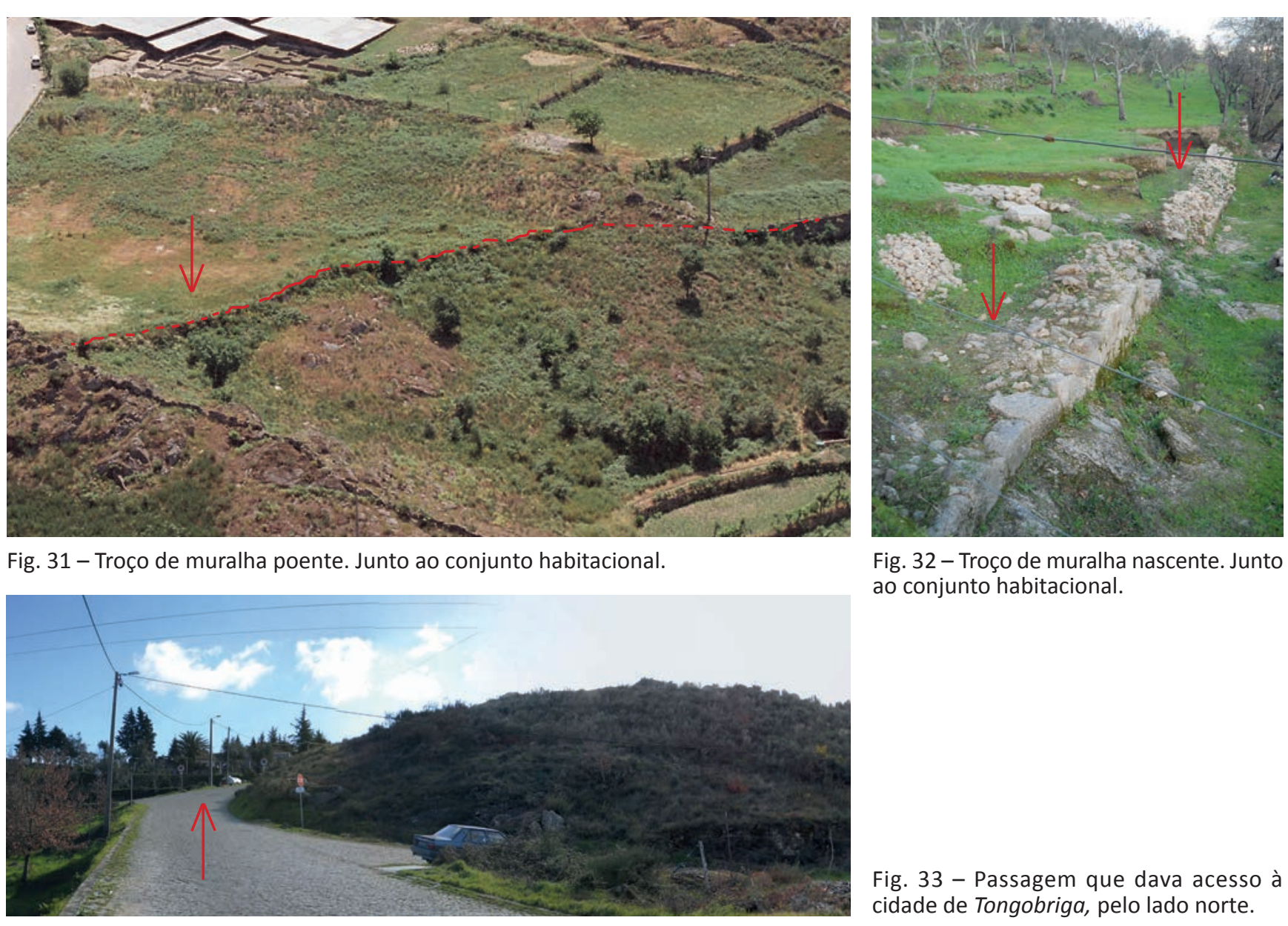

ig. 32 - Troço de muralha nascente. Junto ao conjunto habitacional.

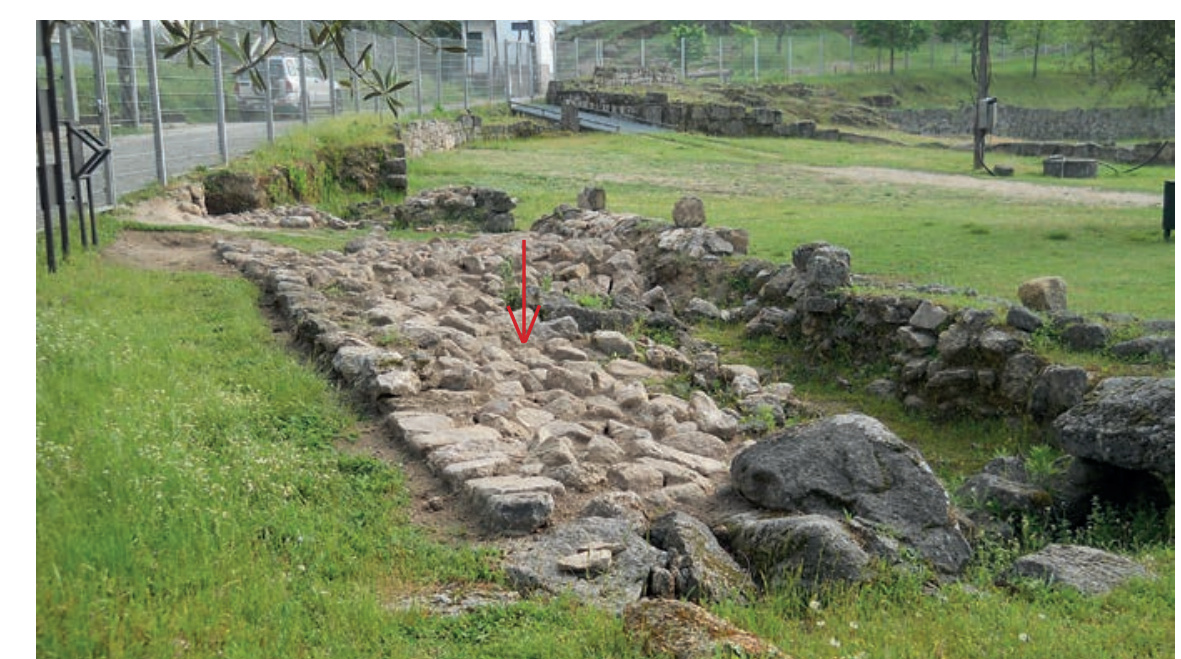

Fig. 34 - Troço de muralha. Junto ao edifício oval, lado nascente.
Fig. 33 - Passagem que dava acesso à
cidade de Tongobriga, pelo lado norte.

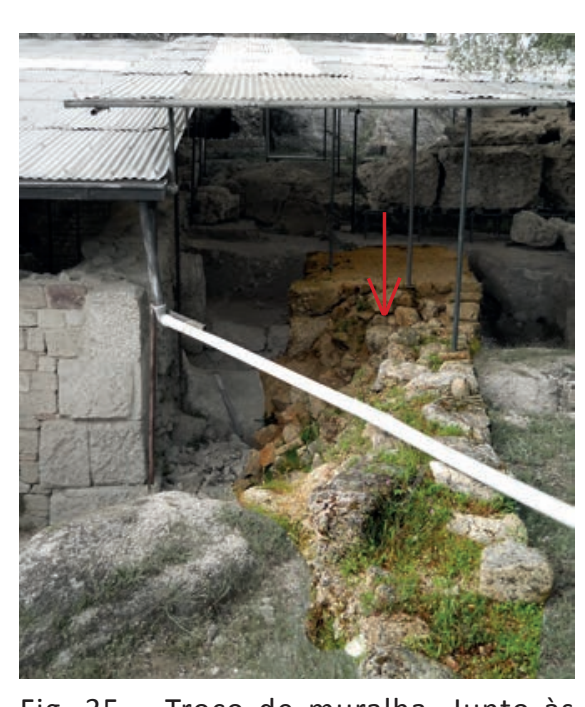

Fig. 35 - Troço de muralha. Junto às 
poente, e um declive, a nascente, a rua passava ao lado de uma necrópole do século I d.C., antes de chegar à muralha. A nascente e a poente seria possível a existência de portas, mas as mesmas ainda não foram identificadas.

Numa segunda fase ${ }^{24}$, nos finais do século I d.C., houve a intenção de criar uma "bolsa" amuralhada para permitir a expansão da área urbana e aí acolher um conjunto de edifícios públicos, que constituí ram o novo centro cívico da cidade. Tal "bolsa" permitiria a construção do forum e os demais edifícios públicos. Com esta ampliação, a cidade abarcava, no total, uma área de cerca de 20 hectares, circundada por uma muralha com cerca de 2 km de extensão (figs. 34, 35, 36 e 37). Nesta nova área de expansão, terá havido uma porta, a sul, que daria acesso ao forum ${ }^{25}$ (figs. 38 e 39 ).

Segundo Lino Tavares, em alternativa à hipótese da ampliação em "bolsa" existe também a possibilidade de esta ampliação ter abrangido uma área mais alargada da encosta poente, correspondendo ao que Vitrúvio explica como exposição solar ideal para a implantação da cidade romana ${ }^{26}$. Mas poucos indícios existem para apoiar esta hipótese, que só futuras sondagens poderão confirmar. Caso existisse esta muralha, contemplaria uma extensão que rondaria $2.15 \mathrm{~km}$, protegendo uma área urbana com cerca 30 hectares (fig. 40).

${ }^{24}$ Consultar Des. 1.05

$25 . .$. o traçado do cardo, depois de atravessar a necropole, era marcado pela entrada na cidade. Desta restam tão só marcas bem vincadas nos afloramentos graníticos, embora nao permitam dizer que ilo de estrulura que all existia. Quem por aqu passada era possivel entrar no forum, pelo lado sul". Lino Dias, Tongobriga, 1997, 30 26 "No que respeita às cidades, serão estes os princípios. (.) Este será alto e não nebuIoso, sem geadas e voltado para o quadrante que não seja nem quente nem frio, mas temperado". Vitrúvio, 1, 4, 1. Tradução de Justino Maciel.

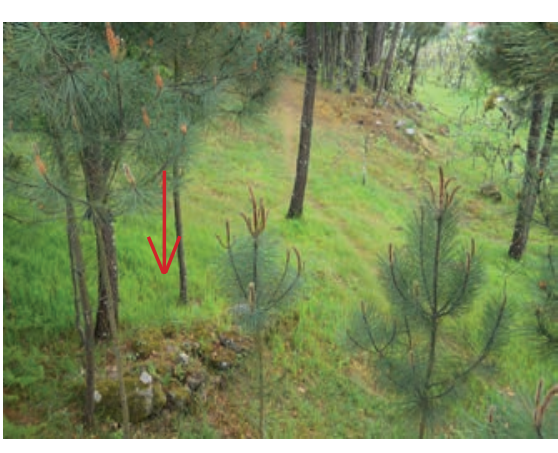

Fig. 36 - Muro que se julga ter pretencido
à muralha da 2.. fase. Norte do Teatro.

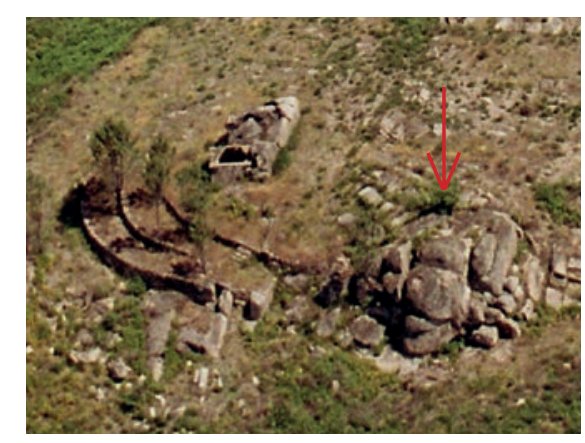
Fig. 37 - Escarpa e muro onde terá pas-
sado a muralha da 2.. fase. Oeste doforum.

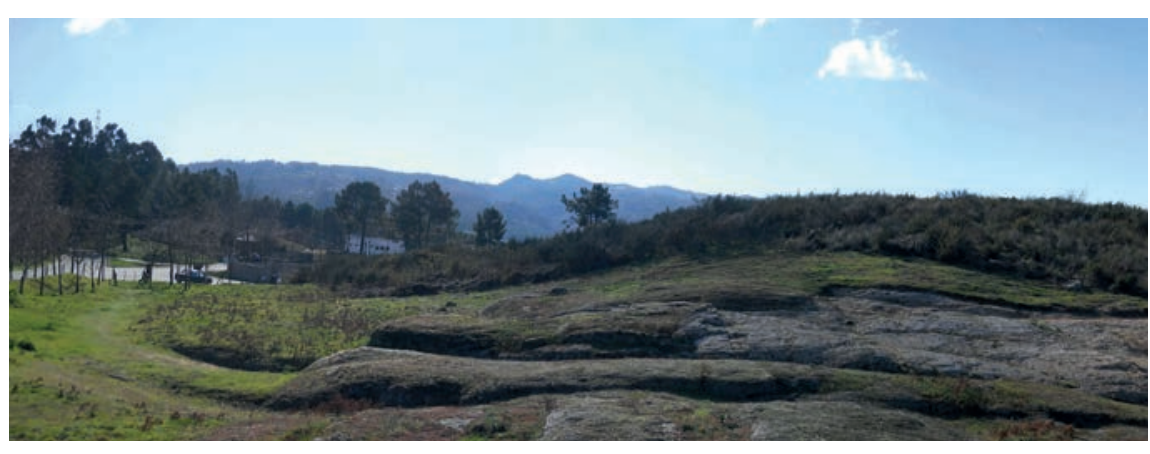
Fig. 38 - Passagem que dava acesso
à porta sul da muralha, na 2.a fase da

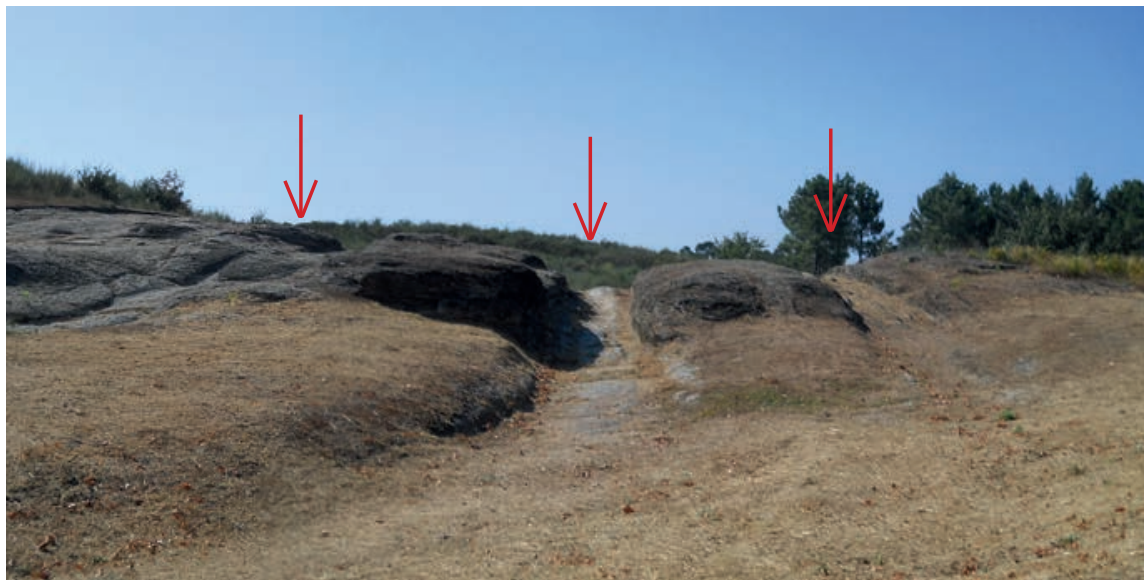

Fig. 39 - Passagem que dava acesso a porta sul da muralh
cidade. Vista de frente.

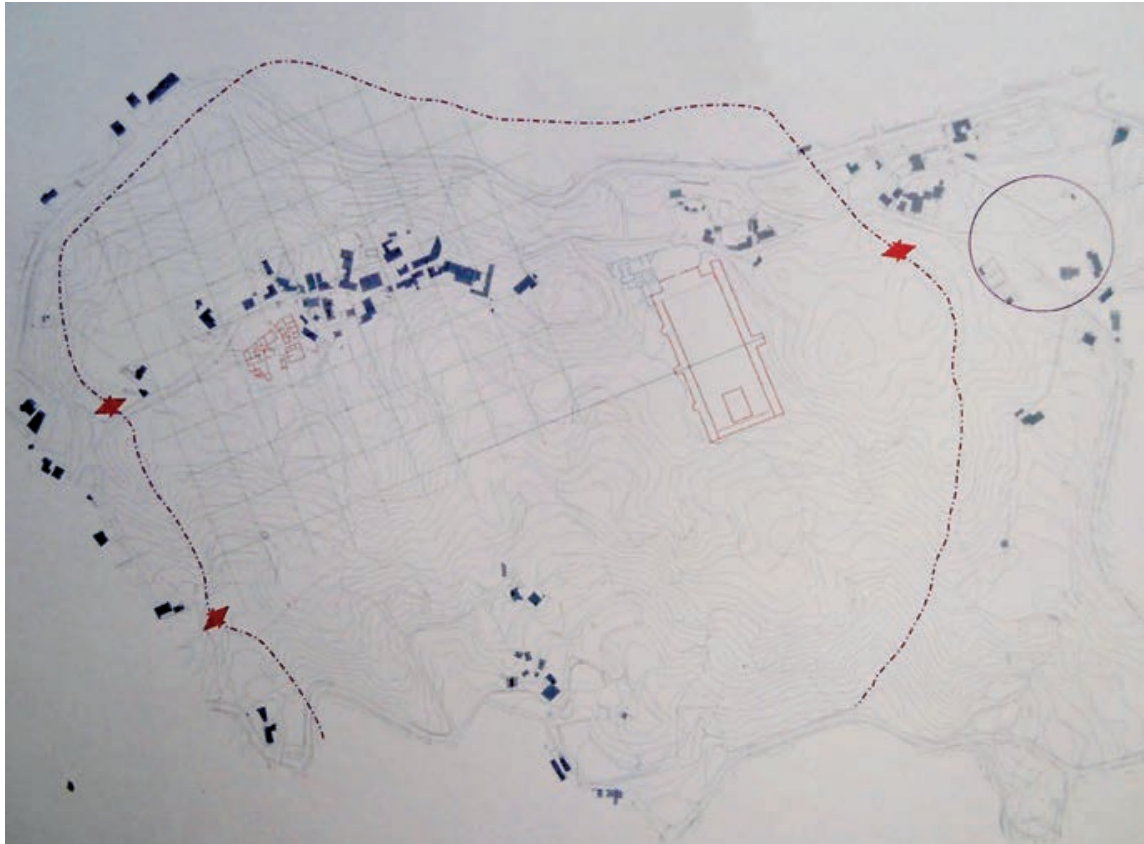

Fig. 40 - Painel expositivo na recepção da Área Arqueologica do Freixo, em que se da cidade (esta abarcaria uma maior área da encosta poente). 
1.3 - Áreas Públicas. Equipamentos Identificados 1.3.1 - Termas

As termas (thermae) faziam parte da vida quotidiana dos romanos, não só por questões de higiene pessoal, mas também como espaço de reflexão, de convívio, de exercício, e até como espaço para reuniões de negócios. Assim, não é de surpreender que esta fosse uma das tipologias usadas na aculturação das províncias (fig. 41).

Termas - "Pedra Formosa"

Ainda antes da construção das termas romanas, existia ali um Balneário Castrejo, do tipo "pedra formosa”, que poderá ter sido um factor relevante na escolha deste lugar para a implantação do balneário romano.

Este equipamento foi todo esculpido no afloramento granítico e estava organizado em quatro espaços. Um amplo pátio lajeado que dava entrada ao conjunto, e os restantes três cobertos: a sala dos bancos; de seguida um espaço rectangular amplo; e, por fim, a fornalha com uma configuração circular, também esta esculpida directamente no afloramento. A água que abastecia este balneário vinha de uma nascente al perto. $O$ balneário esteve em pleno uso até meados da segunda metade do século I d.C. (governo de Vespasiano). Quanto à data da sua construção, não é possível apontar com grande certeza; mas julga-se que terá sido nos finais do século I a.C., ou nos inícios do I d.C. ${ }^{1}$.

Este balneário acabaria por ser desactivado, com a construção das termas romanas (fig. 42)

Termas I

Em Tongobriga, as primeiras termas romanas foram construídas no final do século I d.C., em época flaviana (fig. 43).

A sua localização foi escolhida tendo em conta as características geológicas dos terrenos, as exigências técnicas de adução e evacuação de água, e a sua proximidade a uma nascente (abundante neste lugar). O sítio escolhido, na crista da cadeia montanhosa, facilitava a drenagem dos esgotos para a encosta nascente, onde se encontrava a muralha.

A sua implantação exigiu que os afloramentos graníticos fossem trabalhados, por forma a assentar o edifício no terreno, garantindo assim a solidez dos alicerces e também a contrafortagem dos muros, a norte e oeste.

Ver Tongobriga, Lino Dias, 1997, p. 34

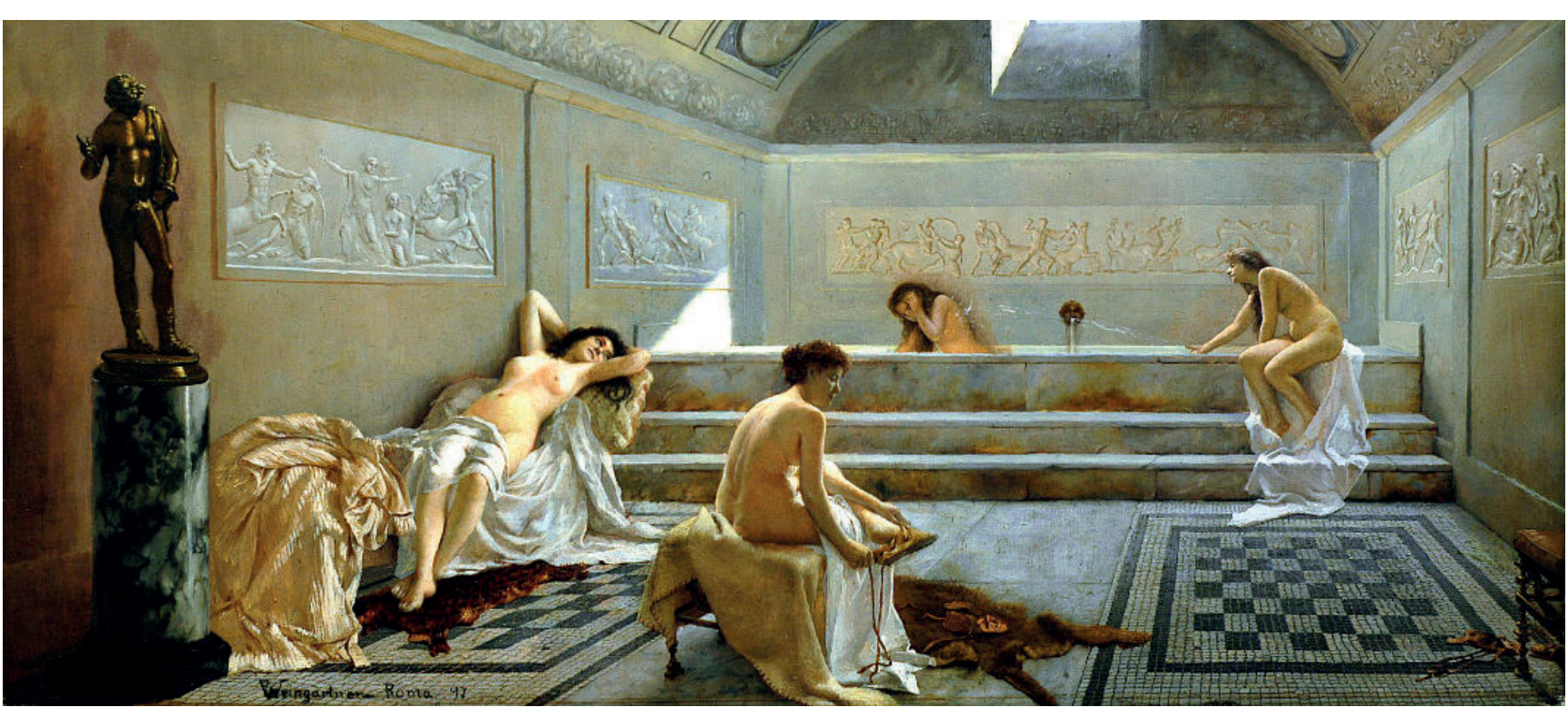

Fig. 41 - Ilustração de um espaço termal romano. Pompeianas no Frigidarium, pintado por Pedro Weingartner (1897).
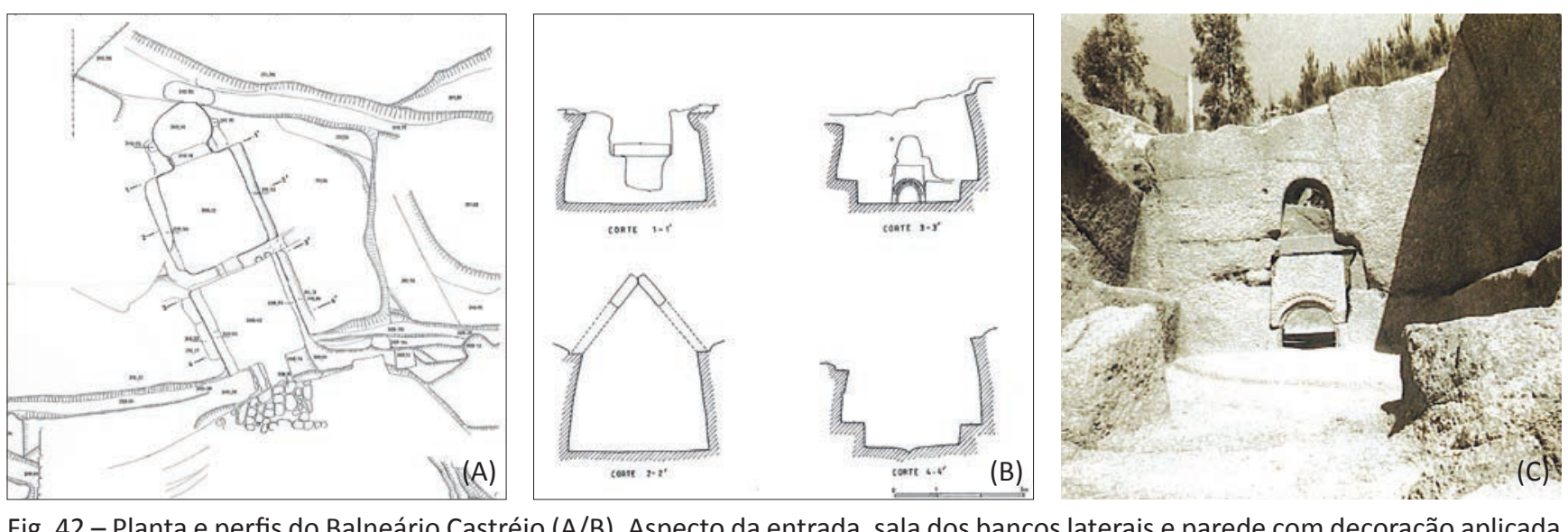

列 (pedra formosa) (C).

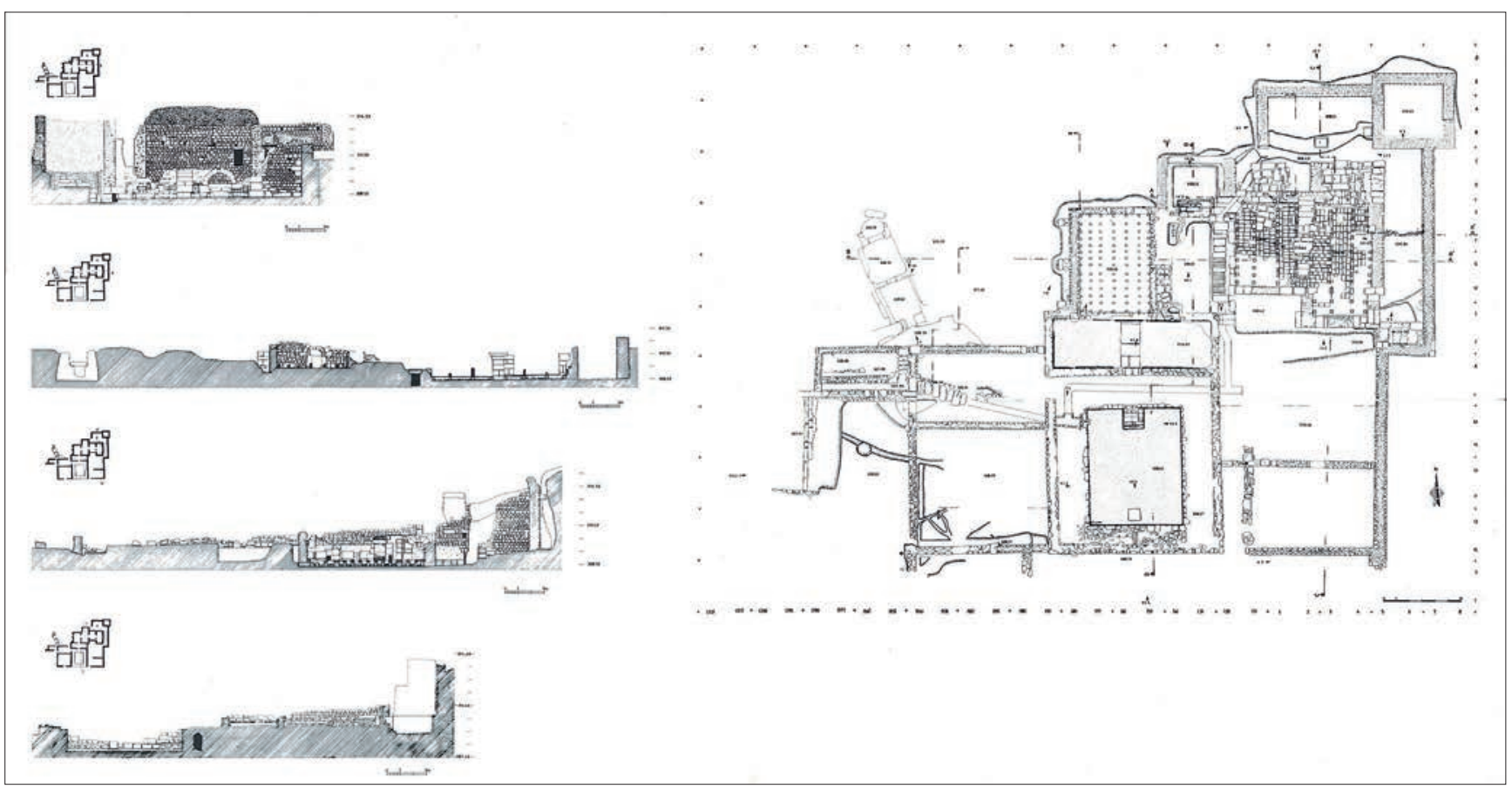

Fig. 43 - Planta e perfis dos vestígios das Termas. 
As termas inseriam-se no terreno, segundo as direcções dominantes da cidade, no eixo poente/nascente, permitindo que a fachada principal tivesse uma boa exposição solar, essencialmente no final da tarde ${ }^{2}$.

De acordo com os vestígios observados em escavação, pode-se concluir que estas termas foram construídas de acordo com um projecto clássico (uma tipologia de planta a que se pode apelidar de "pompeiana"3 ou como "pré-augustana"4), muito semelhante ao que se pode encontrar em Pompeia, ou mesmo em Conimbriga.

Em termos de organização, a entrada principal fazia-se por uma porta, a poente, pois embora a fachada sul fosse a maior, a entrada a poente vinha respeitar os preceitos de orientação vitruviana ${ }^{5}$. Depois de passar a porta, tinha uma palestra (palaestra), murada, provavelmente ensaibrada, onde os utentes poderia realizar exercício físico, antes de entrar no complexo termal (fig. 44). No lado norte da palestra processava-se a entrada no edifício, para o espaço do vestiário (apodyterium).

A partir do vestiário, tinha-se acesso a uma sucessão de salas com ligação axial e organizadas de forma convencional. Estes seriam os banhos frios (frigidarium), os banhos tépidos (tepidarium) (fig. 45) e os banhos quentes (caldarium) (fig. 47), com a sala mais aquecida, a este tendo sido esta a melhor adaptação possível ao local, respeitando os preceitos vitruvianos ${ }^{6}$. No exterior a sucessão destes quatro espaços estava bem identificada no conjunto, pois eram os únicos cobertos com telhado?.

2 "Em primeiro lugar deve escolher-se o lugar mais quente possivel, ou seja, protegido do setentrião (norte) e do aquilão (n) Também se deve ter em conta que os caldário femininos e masculinos sejam colocados juntos e com as mesmas disposições. Assim se procederá, a fim de que, nos equipamentos dos banhos, um hipocausto comum sirva a uns e a outros. Sobre o hipocausto deverão ser colocadas três banheiras de bronze, uma como caldario, outra como tepidario e uma terceira como frigidário, de tal maneira dispostas que, à medida que a água quente vá saindo do tepidário para o caldário, do mesmo modo vá fluindo do frigidario para o tepidario. As abóbadas dos alvéolos serão aquecidas pelo hipocausto comum (fig. 46)". Vitrúvio, 5, 10, 1-5. Tradu-

Romaine, 1984, 286. Citado por Lino Dias em Tongobriga,

政 Atribucion, 1982, p. 126. Citado por Lino Dias em Tongobriga, 1997, p. 35.

am primero har deve escolher-se olugar mais quente possivel, ou seja, protegido do setentria o do aquilão. Vitrúvio, 5, 10, 1. Tradução de Justino Macie.

- "Os próprios caldarios e tepidarios deveráo ter de Inverno luz do poente e se por acaso a natureza do lugar tal impedir deverão então, de toda a maneira, ser virados a su porque o tempo dos banhos e sobretudo desde o meio-dia até à tarde". Vitrúvio, 5, 10 7 "O arquitecto, ao projectar as te

tras termas de entãojectar as termas de Tongobriga, seguiu um esquema vulgar noucentral, o caldarium a nascente e o frigidarium a poente". Lino Dias, Tongobriga, 1997, p. 36.

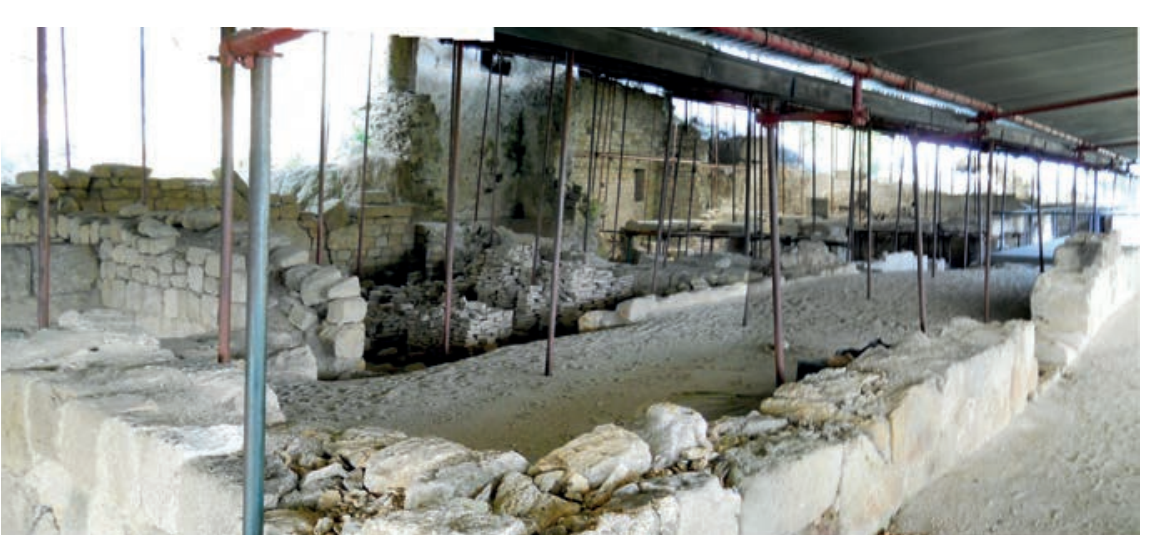

Fig. 44 - Termas, vista panorâmica do conjunto do complexo termal.

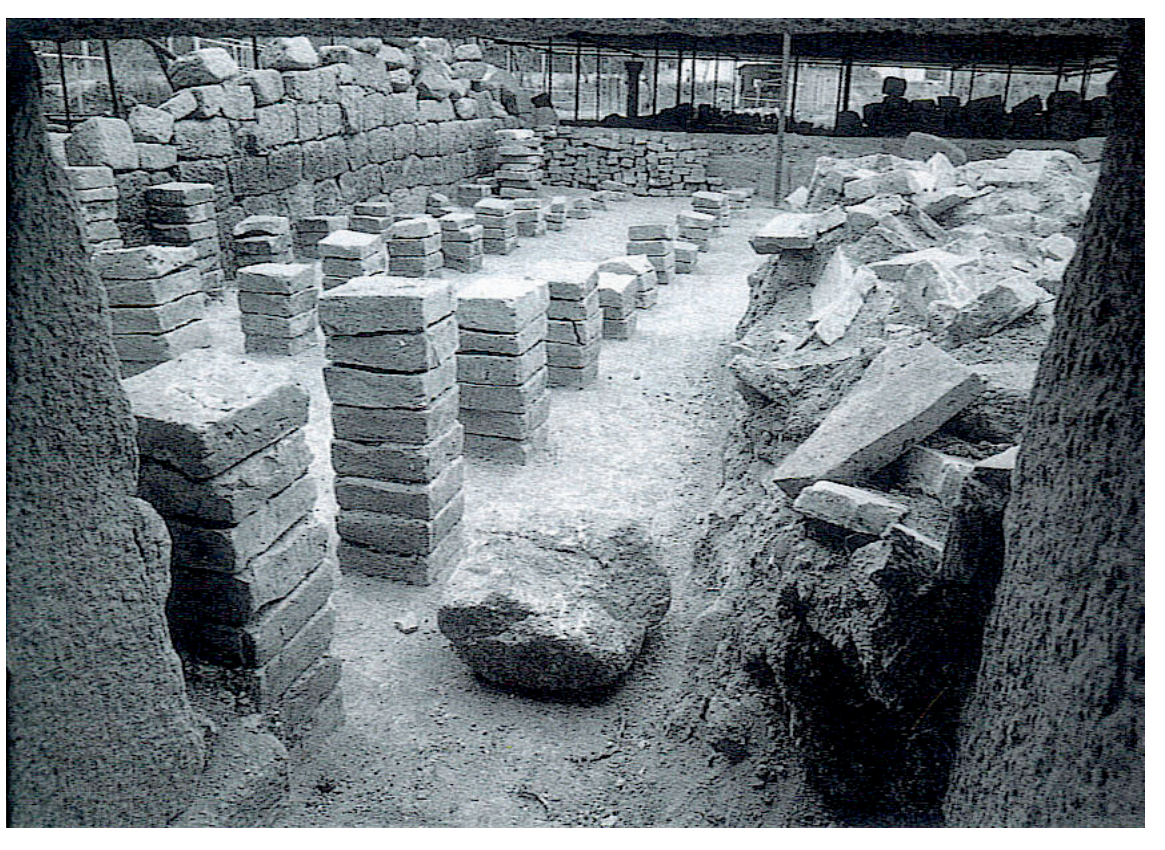

Fig. 46 - Termas, espaço do hipocausto, onde é possivel ver os colunelos construí-

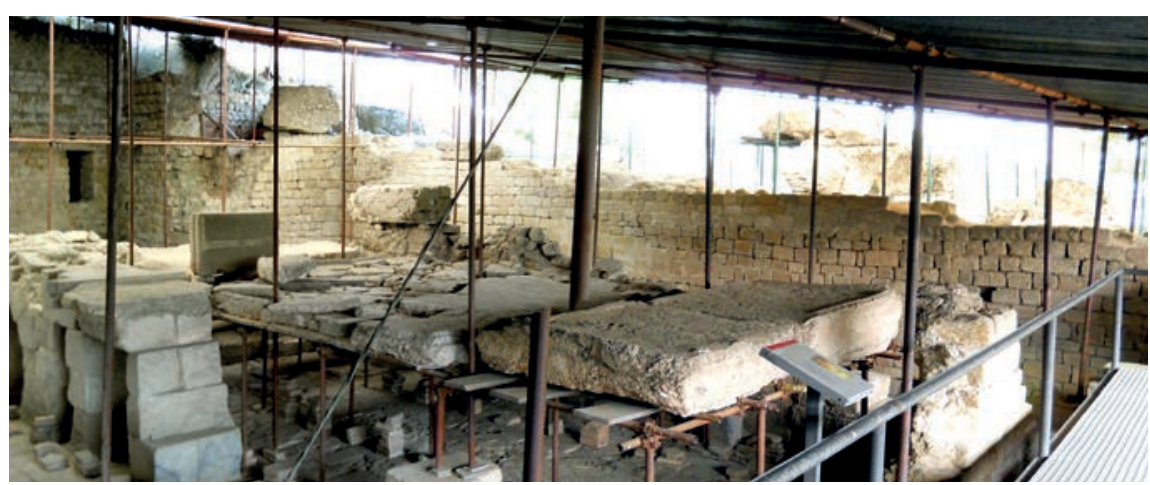

Fig. 47 - Termas, espaço dos banhos quen-

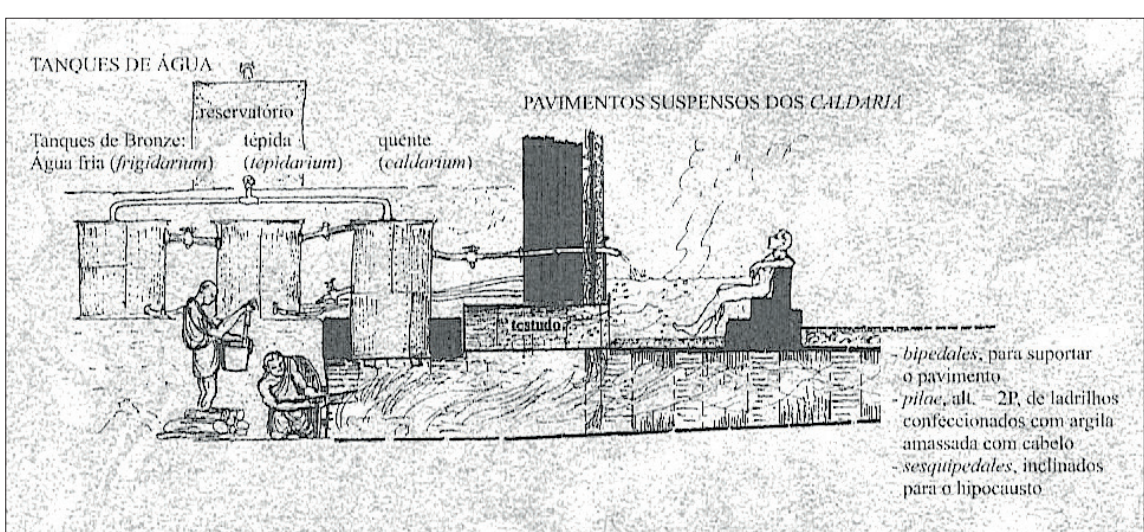

Fig. 48 - Termas. Ilustração de Thomas Noble Howe, que demonstra como a
criadagem alimentava a fogueira, para o aquecimento das águas. 
A norte do conjunto de espaços de banho, junto à muralha, encontram-se as áreas de serviço, essenciais ao funcionamento das termas; onde a criadagem mantinha a fornalha acesa, para o aquecimento da água (fig. 48). $\mathrm{O}$ acesso a este espaço fazia-se ao fundo da palestra (nascente), por um corredor, até chegar a um espaço onde se encontravam as fornalhas (praefurnium) dos banhos quentes e tépidos. Este espaço era coberto por duas abóbadas. Também ai se encontrava a cisterna para o armazenamento de água, à qual o corredor dava igual acesso (figs. 49 e 53).

\section{Termas II}

Contemporaneamente à inauguração do forum, nos finais do século II d.C., algumas reparações foram realizadas aos telhados do edifício. É realizada igualmente uma grande alteração no projecto quando a sul do edifício é construída a zona da piscina (natatio) (figs. 50 e 54).

Esta nova zona era constituída por uma piscina ao ar livre, envolvida por um pórtico de doze colunas, em granito, onde se apoiava uma cobertura. Com estas transformações, as termas de Tongobriga passaram a ter um uso mais apropriado, nas épocas mais quentes do ano; e não apenas nos Invernos rigorosos que se fazem sentir neste lugar ${ }^{8}$.

Com a construção da piscina, na palestra primitiva, efectua-se uma adição de novos espaços, novas entradas, e uma ligeira mudança na circulação do complexo termal. O novo espaço obriga à mudança da entrada, que passa a fazer-se pela zona da natatio. No lado poente instalou-se um vestiário, junto à entrada anterior. Agora, o utente, ao sair do vestiário, passava obrigatoriamente pela zona da natatio, e entrava numa sala rectangular coberta, que terá servido de espaço de massagens (unctorium). Depois dava entrada no espaço que funcionara como vestiário das Termas I, e de que, nesta fase, não se conhece função. Os restantes espaços mantêm as suas funções e lógica de percurso. Quanto à palestra, fica reduzida a um terço, situando-se do lado nascente da piscina.

Com estas remodelações, que acrescentam volumetria na zona sul do complexo, fica alterado aquilo a que podemos chamar de "centro de gravidade funcional"9. Na primeira fase das termas (Termas I), esse centro seria o percurso axial das salas de banho, e agora

${ }^{8}$ J. Delaine, The Design of Public Baths, 1992, 264-5. Citado por Lino Dias em Tongobriga, 1997, p. 40

${ }^{9}$ Ver Tongobriga, Lino Dias, 1997, p. 41

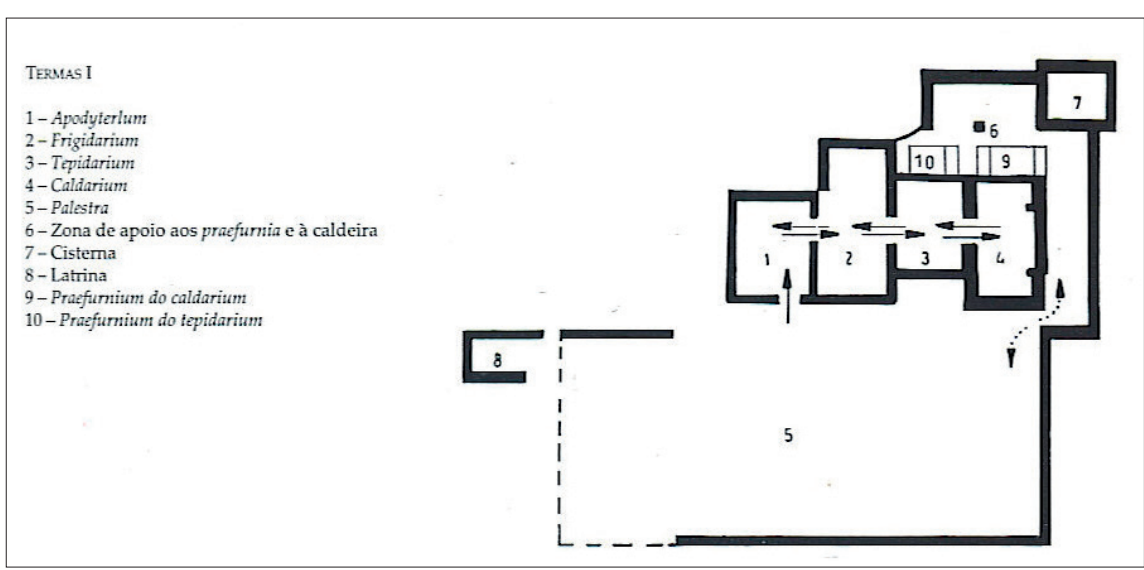

Fig. 49 - Esquema das Termas I.

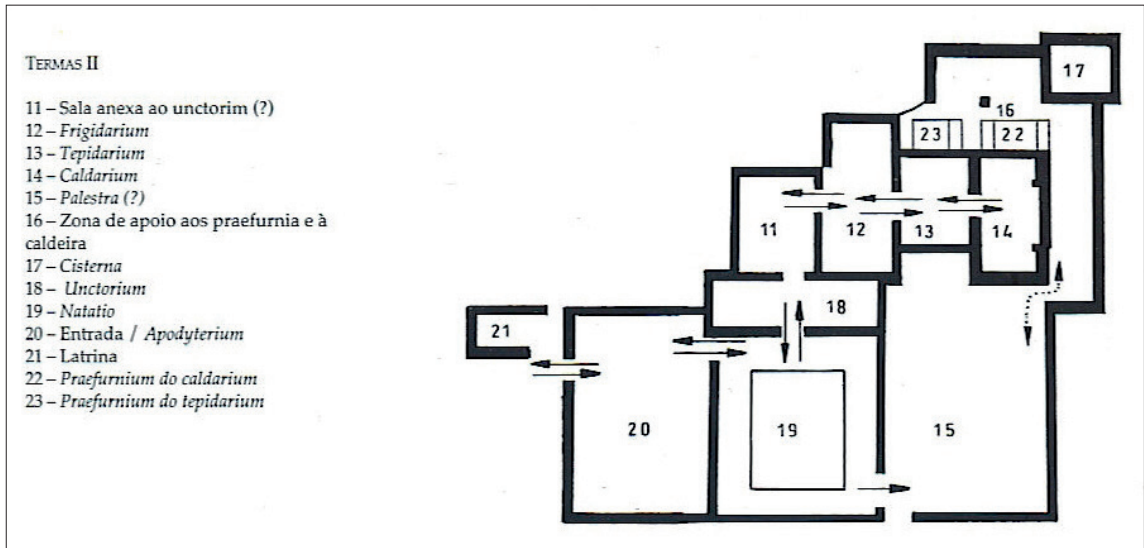

Fig. 50 - Esquema das Termas II.

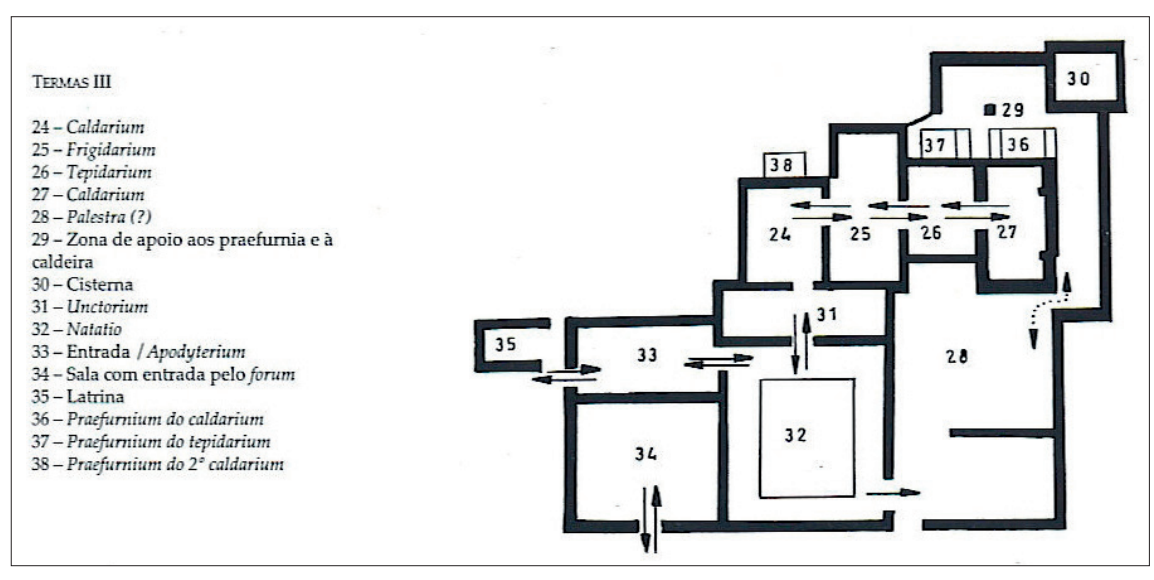

Fig. 51 - Esquema das Termas III.

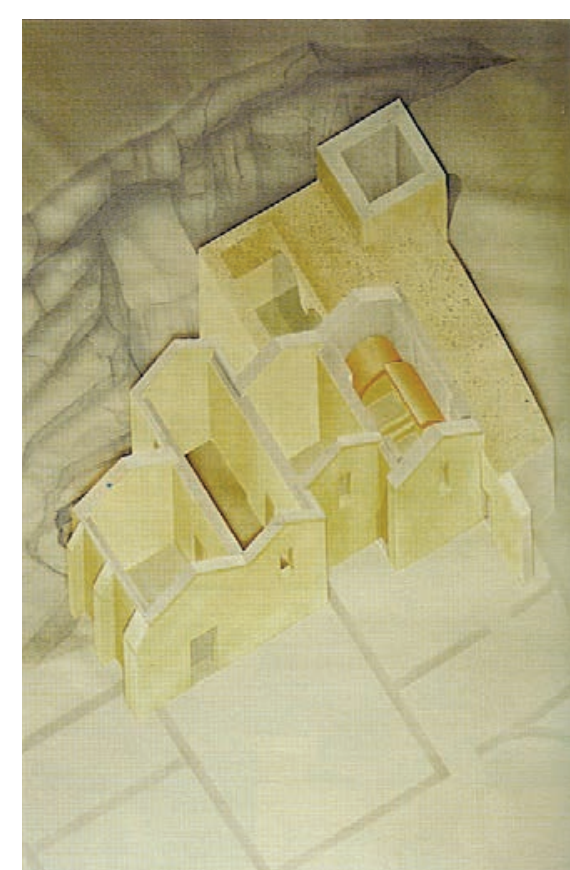

Fig. 53 - Esquema tridimensional das

Termas I, complexo termal:

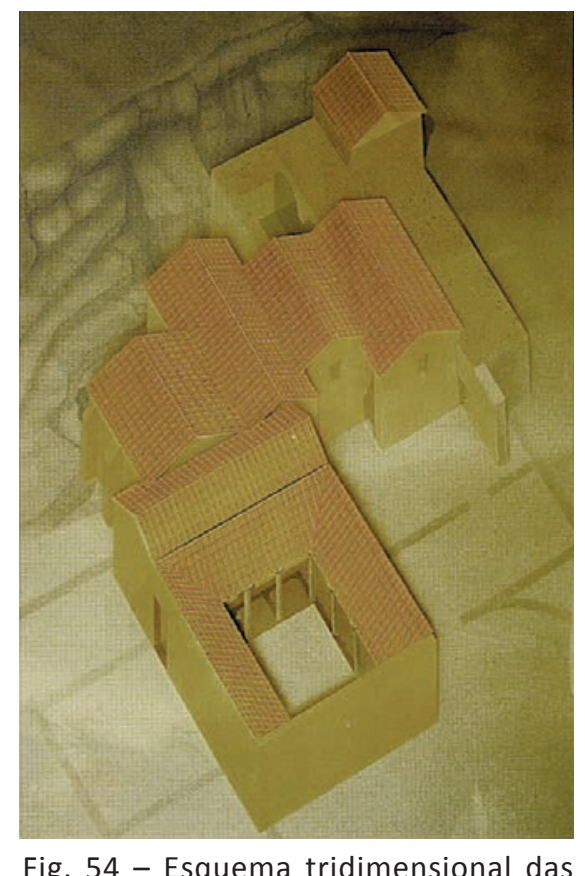

Fig. 54 - Esquema tridimensional das

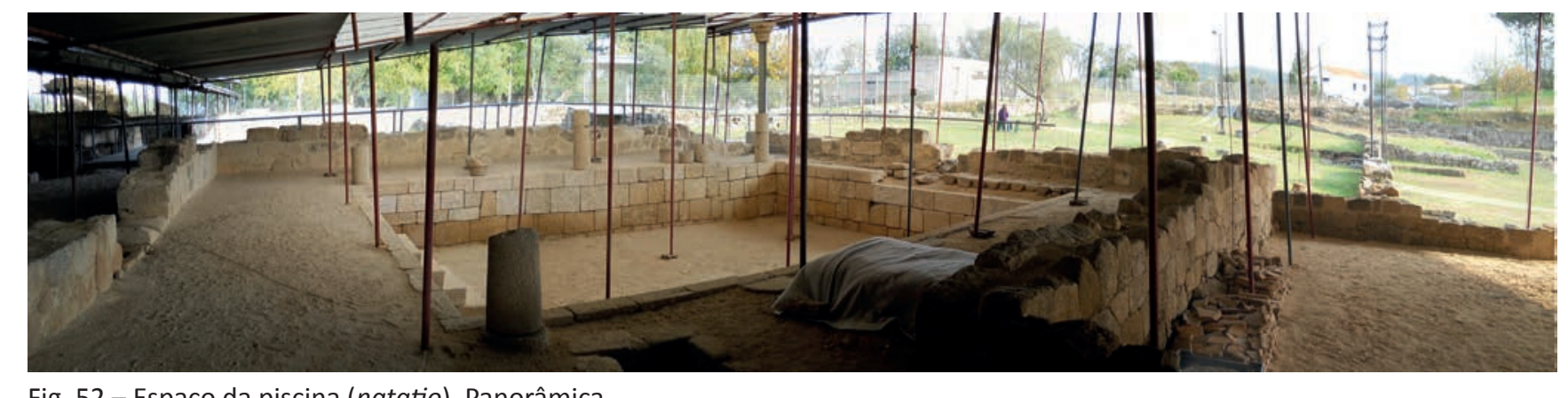

Fig. 52 - Espaço da piscina (natatio). Panorâmica. 
(Termas II) passa para a natatio, que se torna num espaço de passagem inevitável (fig. 52).

No século IV, após 357 , são feitas novas remodelações no complexo termal (fase denominada de Termas III por Lino Tavares). Nesta fase, as termas não sofrem grandes alterações no que diz respeito à arquitectura do edifício. As alterações realizadas correspondem essencialmente a uma troca de usos de alguns compartimentos (fig. 51).

\subsection{2- Forum}

O forum era o ponto fulcral da cidade romana; este espaço correspondia a funções religiosas, políticas e comerciais; sendo que em torno da praça central se reuniam usualmente: as lojas, os templos e outros edifícios de carácter religioso ou político. O forum era, assim, o espaço mais frequentado da urbanização, onde os habitantes podiam reunir e "acompanhar o pulsar da cidade"10.

De entre os vestígios que se exumaram na Área Arqueológica do Freixo, a ruína deste equipamento é a que se apresenta com maio expressão, dada a sua dimensão e estado de conservação. A data da sua construção é apontada para a primeira metade do século II d.C., contemporânea do governo dos Imperadores Trajano e Adriano ${ }^{11}$ (fig. 55).

O forum localiza-se a sul da zona habitacional, junto à muralha, e não no centro da cidade como seria a prática romana ${ }^{12}$. A dificuldade dado o relevo do terreno e a falta de espaço, levou os planeadores romanos a implantá-lo no limite sul da cidade.

O forum implanta-se assim num espaço construído com $149 \mathrm{~m}$ de comprimento e $68,5 \mathrm{~m}$ de largura, o que aparentemente seria muito grande para a dimensão da cidade ${ }^{13}$ (figs. 56 e 57).

De encontro com esse facto, é possível ver o forum não só como o centro cívico da cidade mas também como o centro de um

${ }^{10}$ Lino Dias, "Novos contributos para o Forum de Tongobriga", in Memoriam, 1999, p. 279.

${ }^{11}$ Ver Tongobriga. Breves Reflexões, Lino Dias, 2003, p. 17

12 "Distribuidas as vielas e dispostas as praças, há que proceder, de acordo com a utilldade publica e o interesse comum, a escolha da area para os templos sagrados, para o foro e restantes espaços comuns. Se o recinto fortificado se encontrar junto ao mar, a zona onde se implantara oforo deverá ser escolhida proximo do porto; mas, se estiver no meio das terras, deverá ser implantado no meio do ópido". Vitrúvio I, 7, 1. Tradução 13 "Há toda a convent.

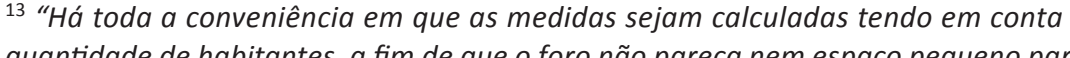
as necessidades, nem largo em demasia pela falta de povo" Vitrúvio, V, 1,2. Traduc ão de Justino Maciel.
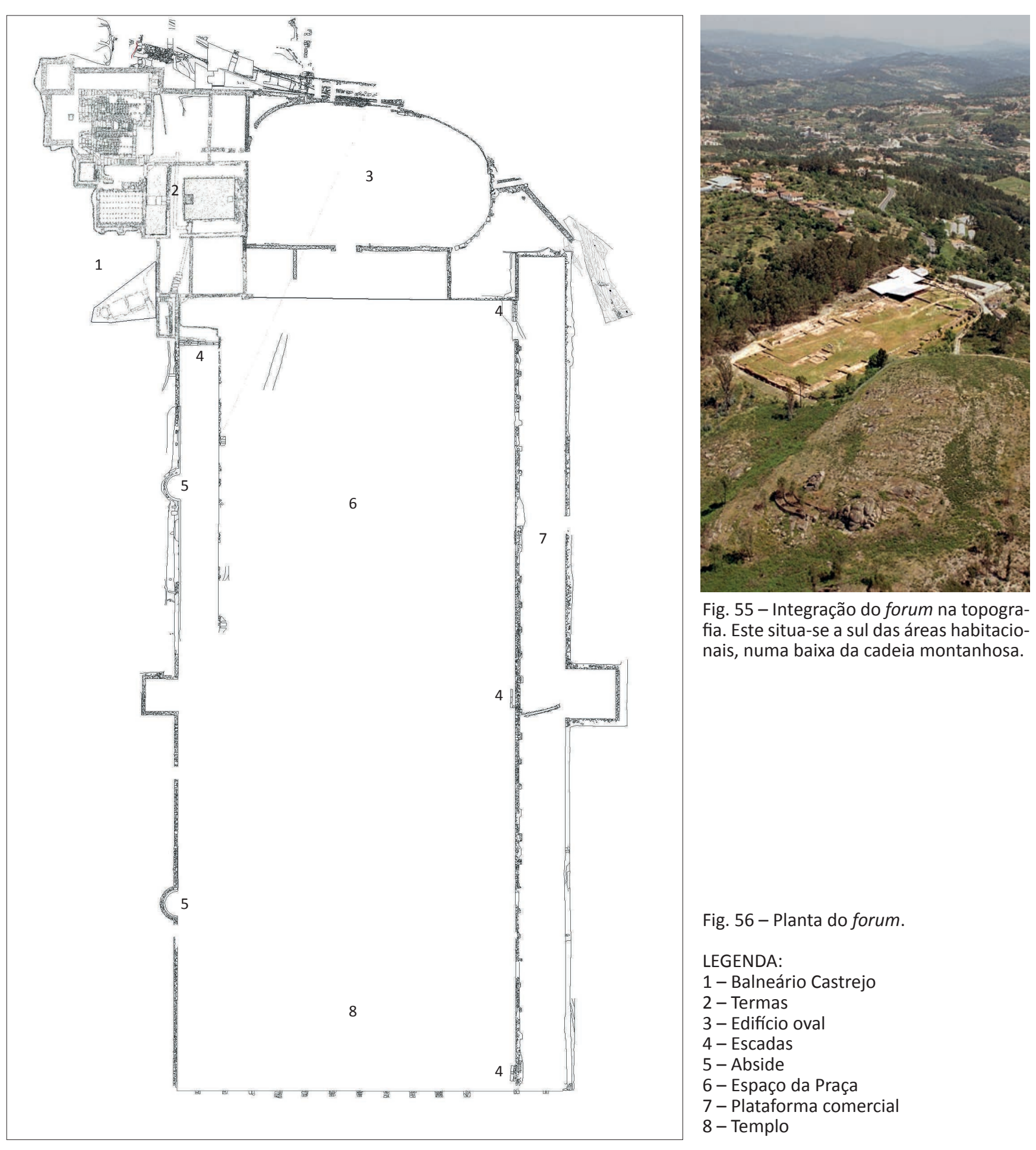

Fig. 55 - Integração do forum na topografia. Este situa-se a sul das àreas habitacionais, numa baixa da cadeia montanhosa.

Fig. 56 - Planta do forum

LEGENDA:

1 - Balneário Castrejo

2-Termas

3 - Edificio ova
4 - Escadas

$4-$ Escadas
$5-$ Abside

6 - Espaço da Praça

7 - Plataforma comercial 8-Templo

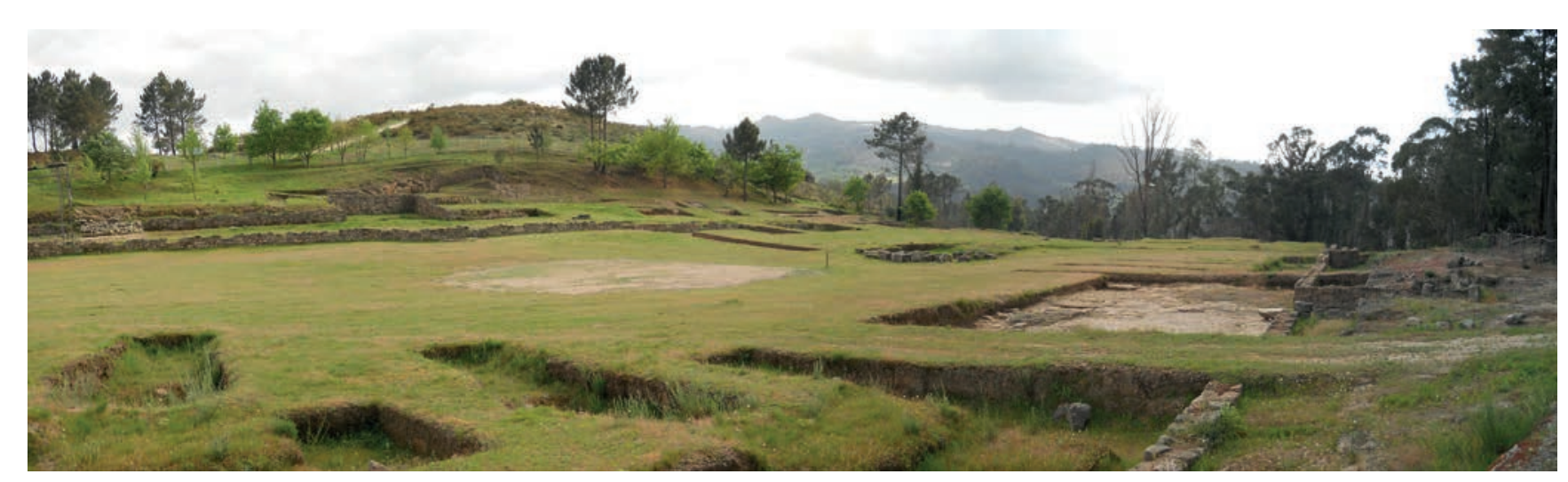

Fig. 57 - Forum. Vista panorâmica no sentido sudoeste. 
território, dado que uma cidade com o estatuto de civitas, como Tongobriga, influenciava uma grande área. Desta forma poder-se-iam justificar as suas dimensões, serviriam um maior número de habitantes.

Um recente texto de Lino Tavares Dias descreve a organização do forum, da seguinte forma:

"Para quem se deslocava na cidade entrava no forum pelo lado norte, perpendicularmente ao seu eixo maior. Estava então perante um espaço de cerca de $10.000 \mathrm{~m}^{2}$ (fig. 58). Em frente, uma plataforma com muros em aparelho poligonal, com 94 passus de comprimento e seis passus de largura, porticada com colunas espaçadas três passus, apoiadas em alicerces de opus quadratum, com excepção do espaço de quatro passus entre a 8..$\underline{a}$ e 9..$\underline{a}$ coluna, desenhado como ponto central e de simetria do porticado, cuja colunata com altura de quatro módulos suportava a cobertura de duas águas em telha. O acesso ao espaço comercial porticado fazia-se por três escadarias com altura de meio modulo (gradus) situadas no centro e nos topos este e oeste (fig. 59).

Para além deste longo espaço porticado, quem entrava no forum encontrava à sua direita (oeste) um podium e o templo. Ao centro a praça. À esquerda (leste) a eventual basílica estava ligada por uma passagem de 15 passus de largura marcada por colunas e que servia também de eixo de simetria do forum, evidenciando-se como elemento importante na definição visual da praça. Nas paredes que limitavam o lado norte do forum foram construídas duas absides onde foi recolhida uma ara invocadora de deus protector da cidade ${ }^{\prime 14}$

Ainda sobre o limite norte do forum, paralelamente ao muro que limitava o espaço da praça, existia uma rua ${ }^{15} \mathrm{com} 7,05 \mathrm{~m}$, que terminava no topo nascente, com três degraus em pedra, com a mesma largura da rua, e que dava acesso às termas (figs. 60 e 61).

Junto à rua, do lado norte do forum, foi detectada a existência de algumas valas cortadas regularmente no afloramento rochoso. Estas são paralelas entre si e perpendiculares ao traçado da rua. Sobre estas não se conhece uma função particular, embora algumas hipóteses sejam levantadas ${ }^{16}$

${ }^{14}$ Lino Tavares Dias, Sintese Tongobriga (texto em edição), 2011.

Durante a escavação chegámos a por a hpoblese de estarmos perante um espaço

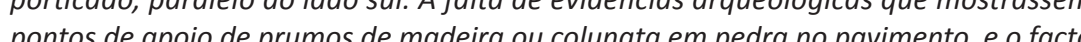
de só termos recolhido telha na zona da abside, levou-nos a apresentar a interpre facto daquele espaso como rua" lino Dias, "Novos Contributos Sobre o Forum de Tongobriga", op. cit., 1999, p. 284.

${ }^{16}$ Ver "Novos Contributos Sobre o Forum de Tongobriga”, op. cit., Lino Dias, 1999, p. 282.

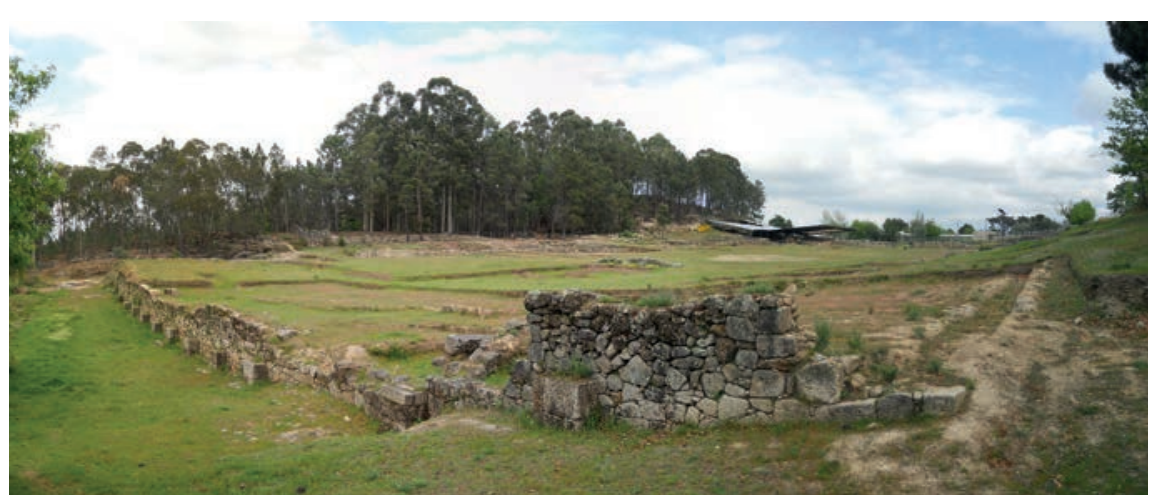

Fig. 58 - Forum. Vista panorâmica no sentido nordeste.

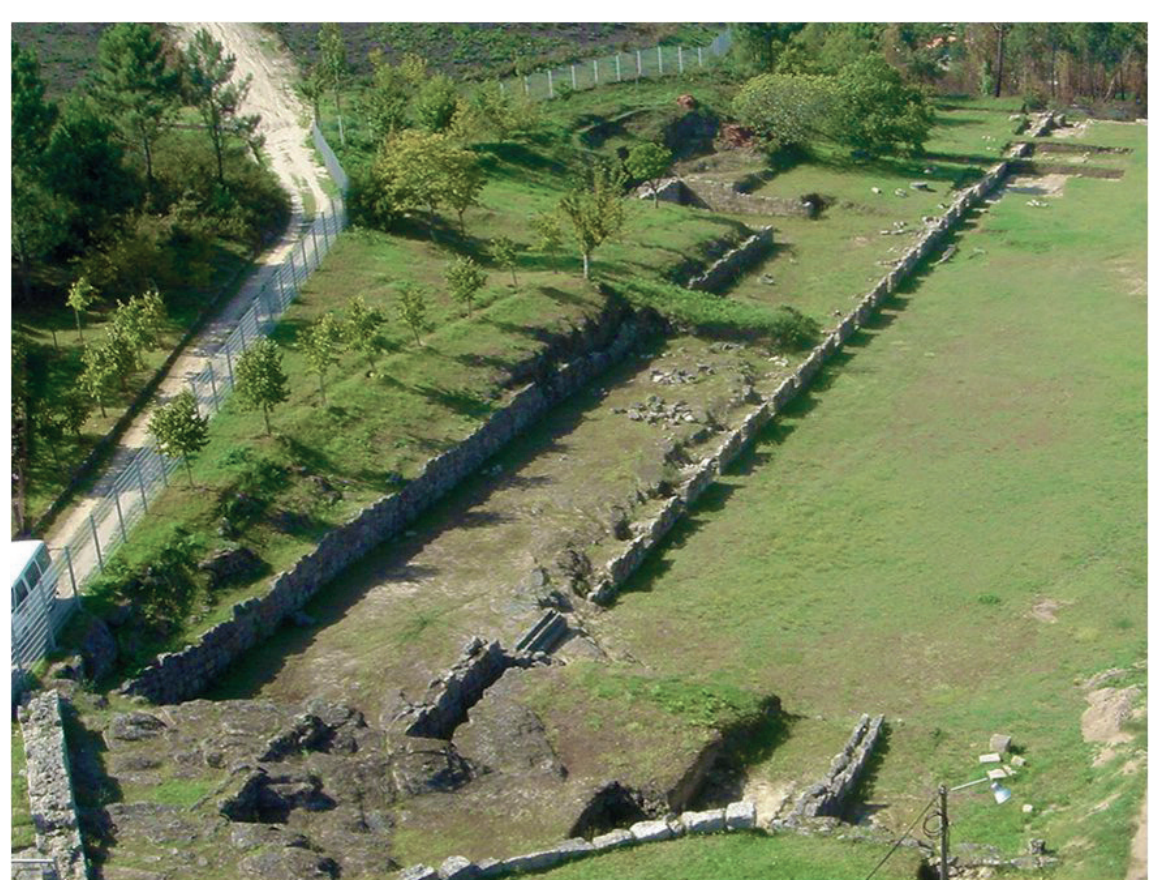

Fig. 59 - Plataforma comercial. Vista no sentido nascente-poente.
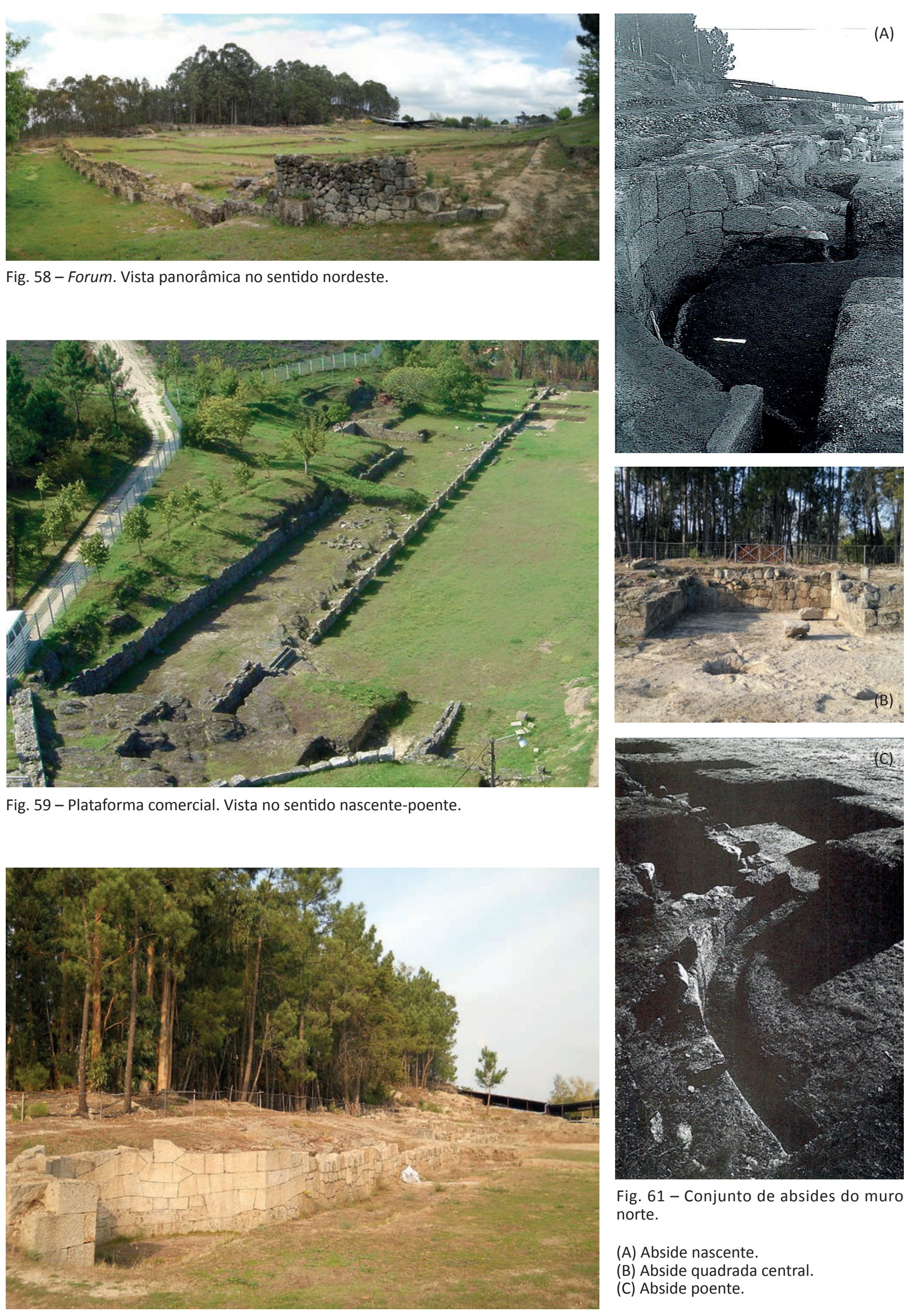

ig. 61 - Conjunto de absides do muro

(A) Abside nascente A quadrada central.

Fig. 60 - Limite norte do forum. 


\subsection{3 - Teatro}

O teatro foi um equipamento cultural generalizado por todas as cidades romanas, incluindo as províncias do império, e cuja finalidade era a criação de um espaço apto para a interpretação de peças teatrais do período clássico. Esta foi, também, umas das construções que fez parte da política de romanização dos povos conquistados.

Em Tongobriga a sua localização foi identificada por Lino Tavares através da análise da morfologia do terreno e de observações em fotografia aérea. Este situar-se-ia na encosta poente, seguindo os preceitos vitruvianos ${ }^{17}$, junto ao cardo que saía a norte do forum ${ }^{18}$. A sua cávea estaria bem adaptada ao terreno, construída de modo a tirar proveito da morfologia dos afloramentos graníticos ${ }^{19}$, e permitindo assim o acesso pela cota superior da cávea, característica patente entre outros teatros romanos ${ }^{20}$ (figs. 63, 64, 65 e 66).

\subsection{4- Circo}

O circo romano era uma das instalações lúdicas mais importantes das cidades romanas. Juntamente com o teatro e o anfiteatro, forma a trilogia de instalações de cultura e divertimentos da época. Era destinado a corridas, espectáculos e representações que comemoravam os acontecimentos do império.

Segundo Lino Tavares, Tongobriga teve um circo, do qua restam poucos vestígios, principalmente devido aos trabalhos agrícolas ali realizados nas décadas de 60 e 70 do século $X X^{21}$.

A sua localização foi identificada por fotografia aérea, a noroeste da urbanização, já numa zona extramuros, como ditavam as normas da época ${ }^{22}$. Este era servido pela mesma estrada que ligava Tongobriga à ponte sobre o Rio Tâmega (fig. 62). Com uma dimensão de cerca de

17 "Providenciar-se-á também que (o teatro) não receba o ímpeto do sul. Com efeito, inflama-se, movendo-se sobre si próprio, cresta e queima, ardente, esvaindo a humidade dos corpos. Por essa razão devem ser evitadas ao máximo, face a estas coisas, as exposições doentias, e se escolherão as salubres". Vitrúvio, V, 3, 2. Tradução de Justino Maciel. ${ }^{18}$ Localização apontada por Lino Dias.

"Mais fácil será a preparação dos fundamentos se se construir nos montes; mas se necessidade obrigar a que a largura plane ou palustre, deverão ser lançados alicerces e muros semelhantes às fundaçoes dos templos sagrados, como for escrito no Livro III" Vitrúvio, V, 3, 3. Tradução de Justino Maciel.

ler El Trazado Vitruwano Jomo mecanismo abierto de implantación y ampliación de 152, p. 153. Referido por Lino Dias em Tongo${ }^{21}$ Ver Tongobriga,

${ }^{22}$ Ver "Circo Romano nas Ruínas do Freixo?", in Tongobriga. Contributo Documental 1999, pp. 192-93.
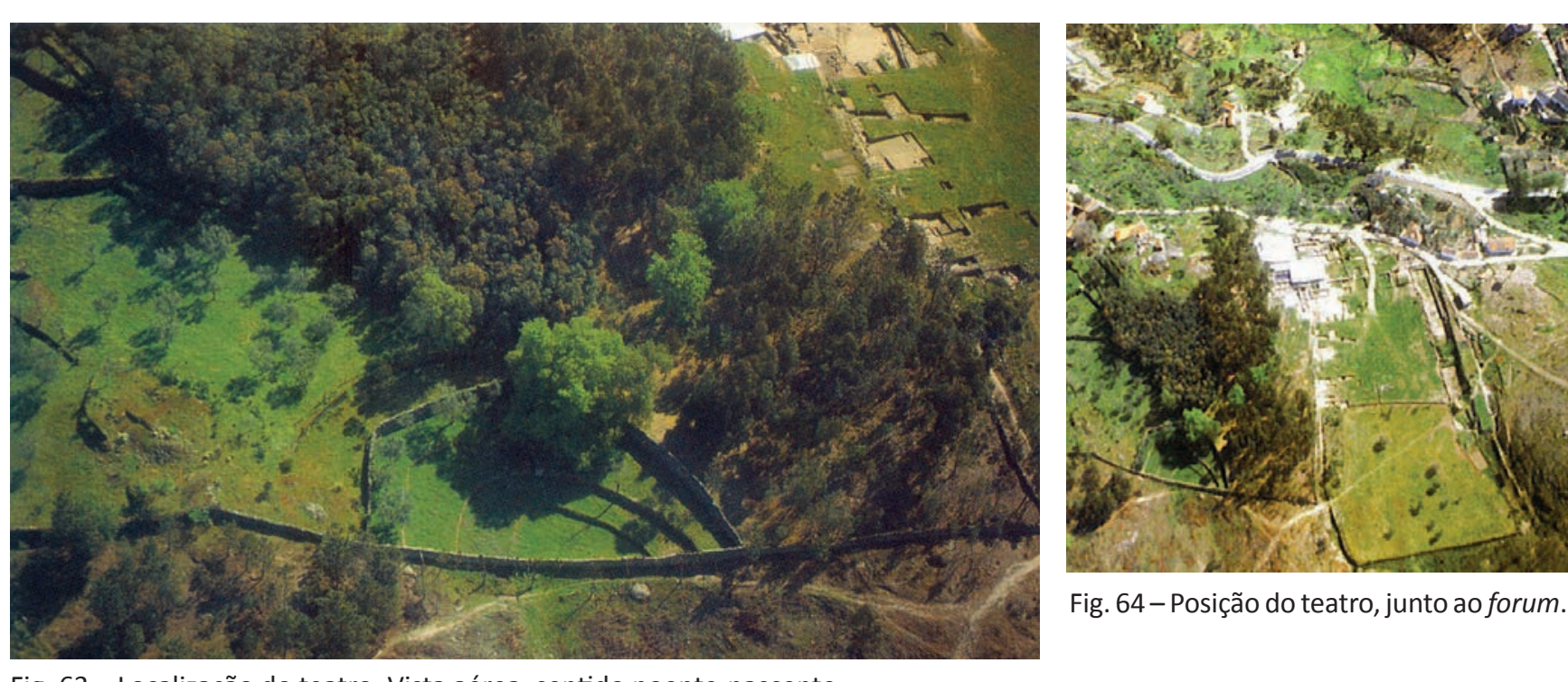

Fig. 64-Posição do teatro, junto ao forum

Fig. 63 - Localização do teatro. Vista aérea, sentido poente-nascente.

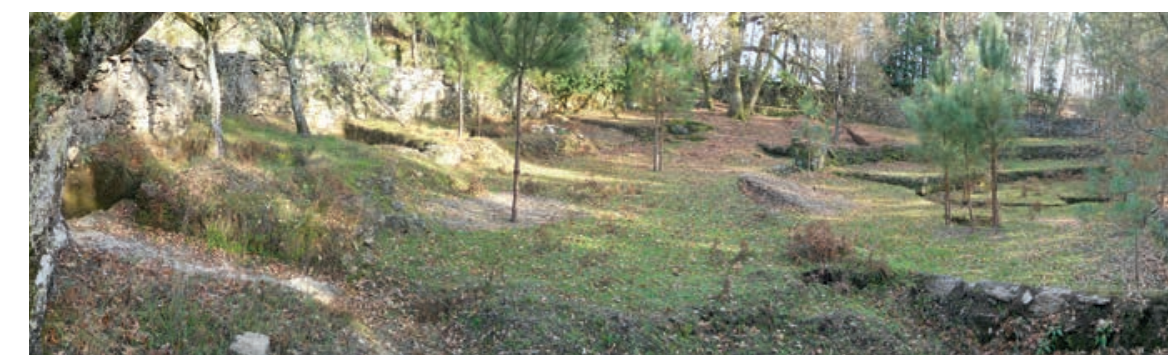

Fig. 65 - Teatro. Vista panorâmica no sentido sul.

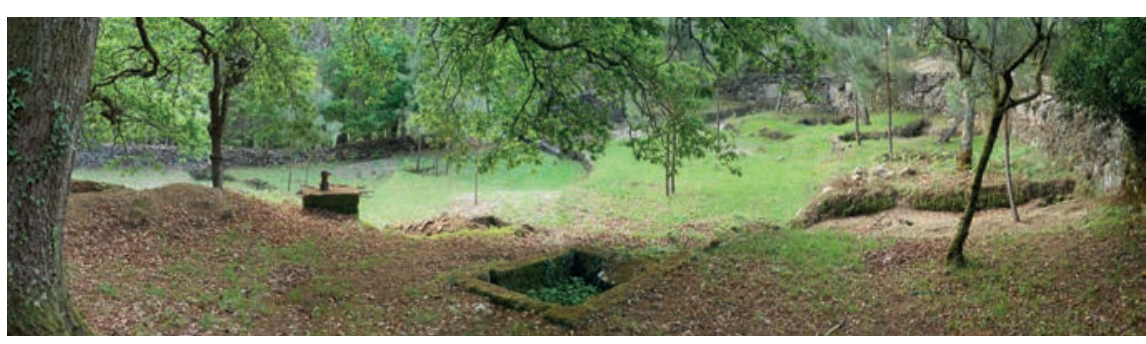

Fig. 66 - Teatro. Vista panorâmica no sentido norte.

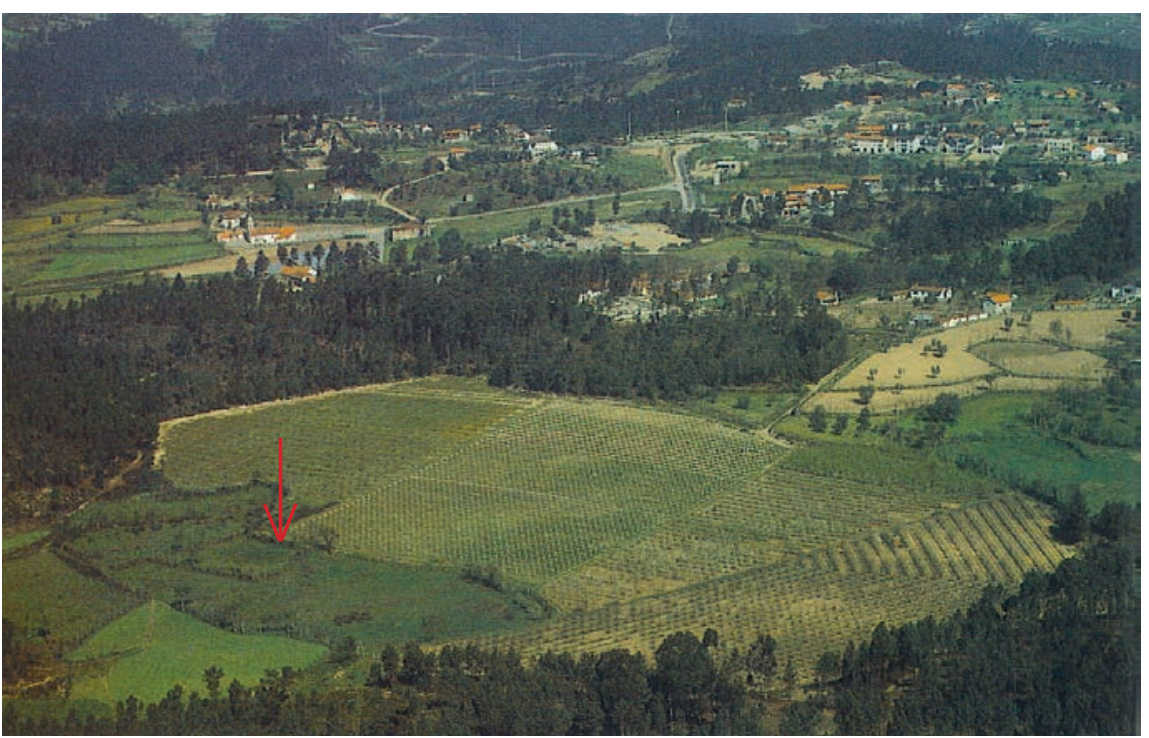

Fig. 67 - Aspecto do espaço onde se identificou as estruturas do eventual circo.
Vista aerea no sentido norte.

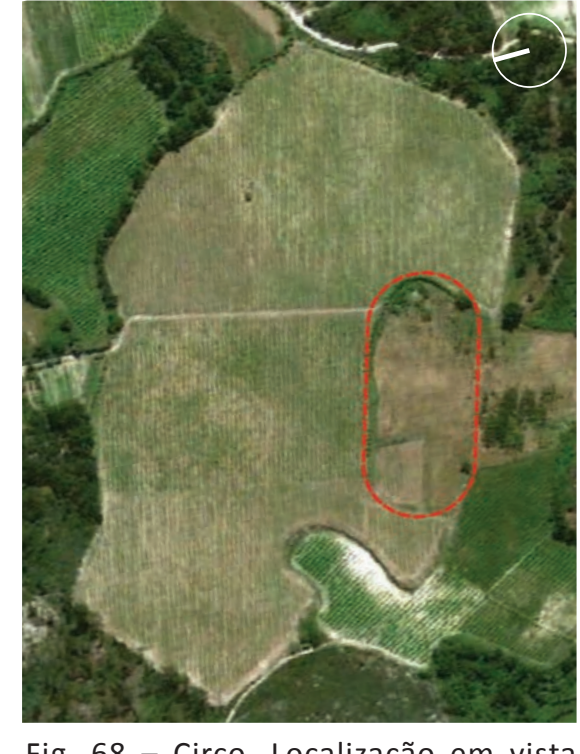

Fig. 68 
$148 \mathrm{~m}$ de comprimento e $64 \mathrm{~m}$ de largura, veio encontrar ali um espaço amplo, que, aproveitando uma depressão no terreno, se implantou a uma cota constante de $240 \mathrm{~m}$. Essa depressão criava um talude que foi, em tempos, adaptado a bancada, e hoje parte desse talude constitui um dos raros vestígios ainda visíveis ${ }^{23}$ (figs. 67 e 68).

\subsection{5 - Igreja Paleocristã}

Os romanos tinham uma religião que se caracterizava pelo politeísmo, resultado de uma combinação de influências, de diversos cultos ao longo da sua história. Mas, posteriormente, a partir de inícios do século IV, o imperador Constantino converte-se ao cristianismo, e pouco depois, já em finais do século, o cristianismo foi adoptado como a religião oficial do império. É interessante perceber como acontecimentos deste género na capital do império têm influência na alteração dos costumes de uma cidade de província, periférica, como Tongobriga.

Em recentes sondagens realizadas no actual adro e Igreja de Santa Maria do Freixo ${ }^{24}$, foi possível confirmar a existência de uma Basílica Paleocristã, datada dos séculos V e VI. As dimensões desta excediam, tanto em comprimento como em largura, a planta da actual igreja, contendo assim uma área de $210 \mathrm{~m}^{2}$. Para esta Basílica Paleocristã aqui ser implantada o afloramento granítico foi nivelado e regularizado, por forma a receber o edifício (figs. 70 e 72). No seu interior, o pavimento era revestido por um mosaico policromo, composto por seis cores (fig. 71). Relativamente às suas proporções, estas aparentam corresponder ao preceito de Vitrúvio (fig. 69) ${ }^{25}$.

A riqueza deste pavimento e as dimensões atribuídas à basílica levam a crer que a centralidade de que a cidade de Tongobrig desfrutava não se esvaeceu completamente com a queda do império romano, no século $\mathrm{V}^{26}$.

Fig. 69 - Basílica Paleocristã. Esquema da proporcional, de um dos precertos vitruvianos.

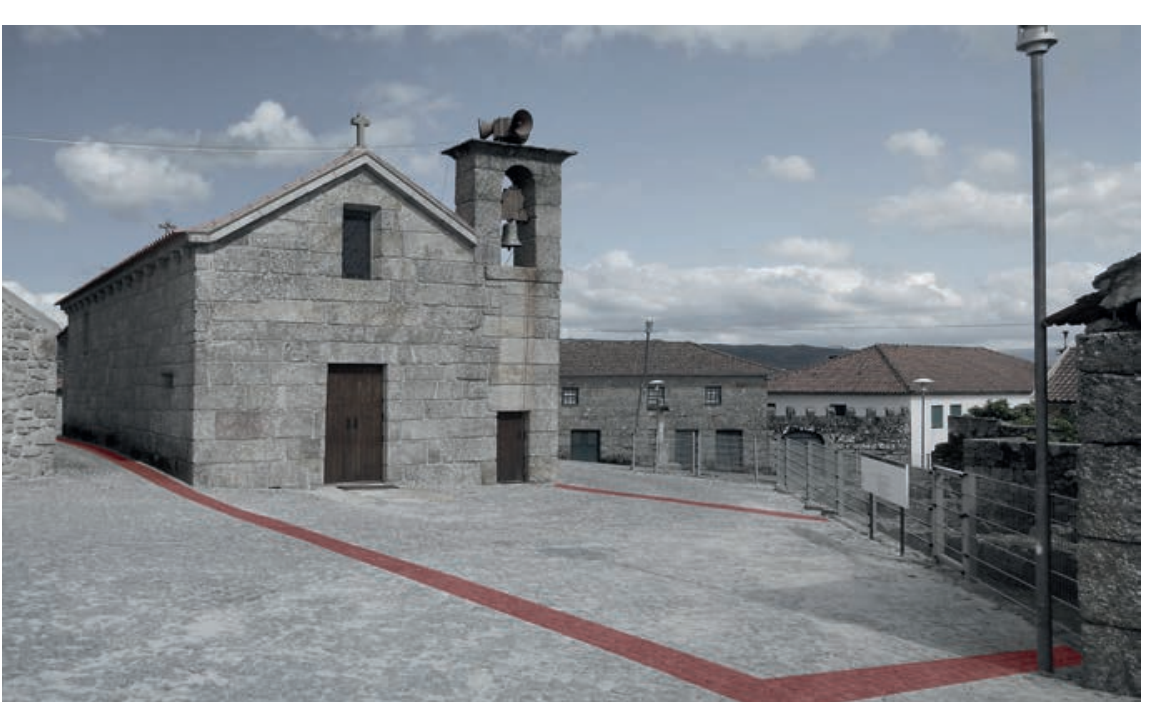

Fig. 70 - Igreja de Santa Maria do Freixo, onde foram descobertos os vestígios da Basílica Paleocristã. Vista exterior no sentido nascente, e a sombreado vermelho, o delineamento das fundações da baślica.

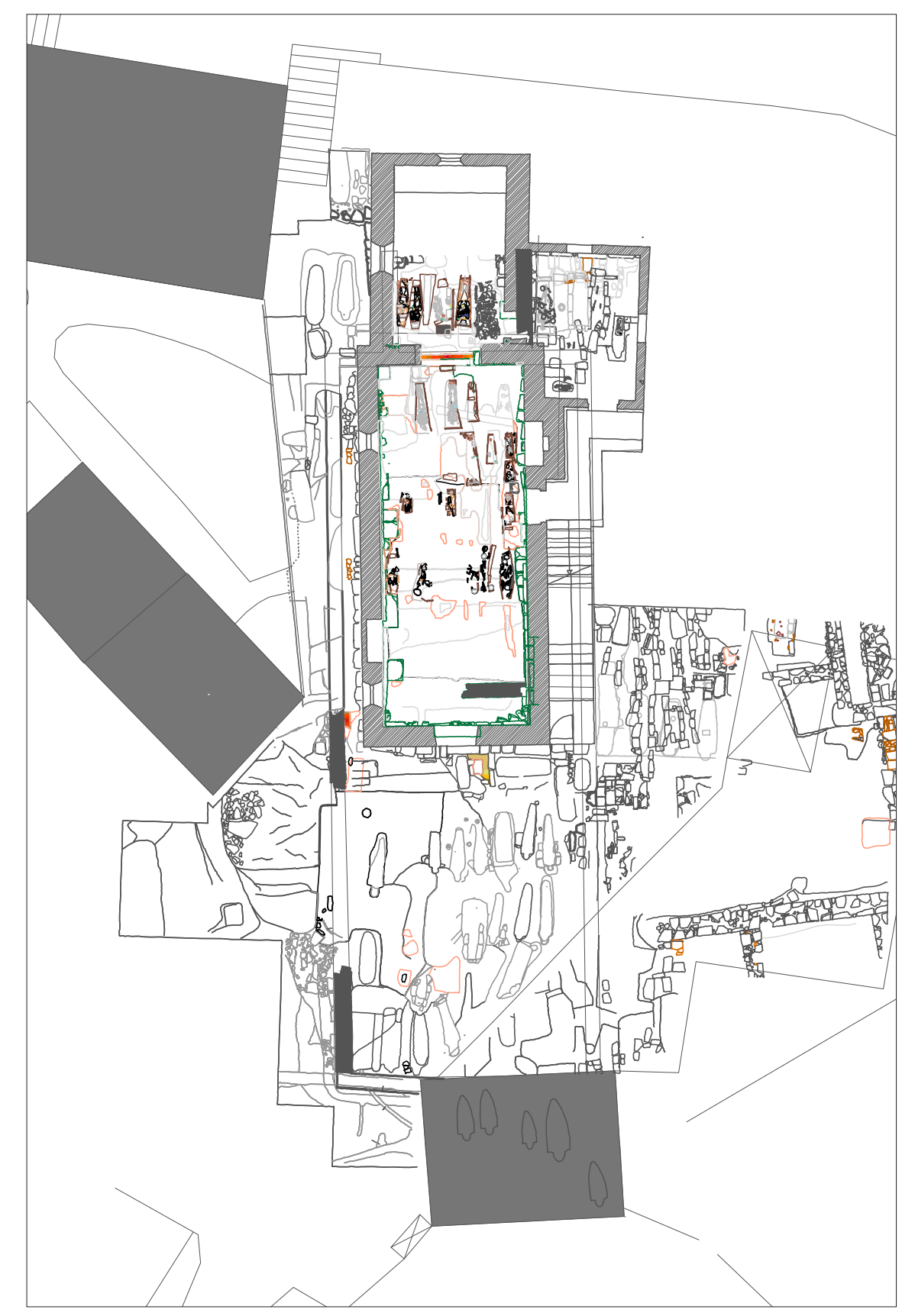

Fig. 72 - Planta do registo das sondagens
na área da lgreja de Santa Maria do Freixo.
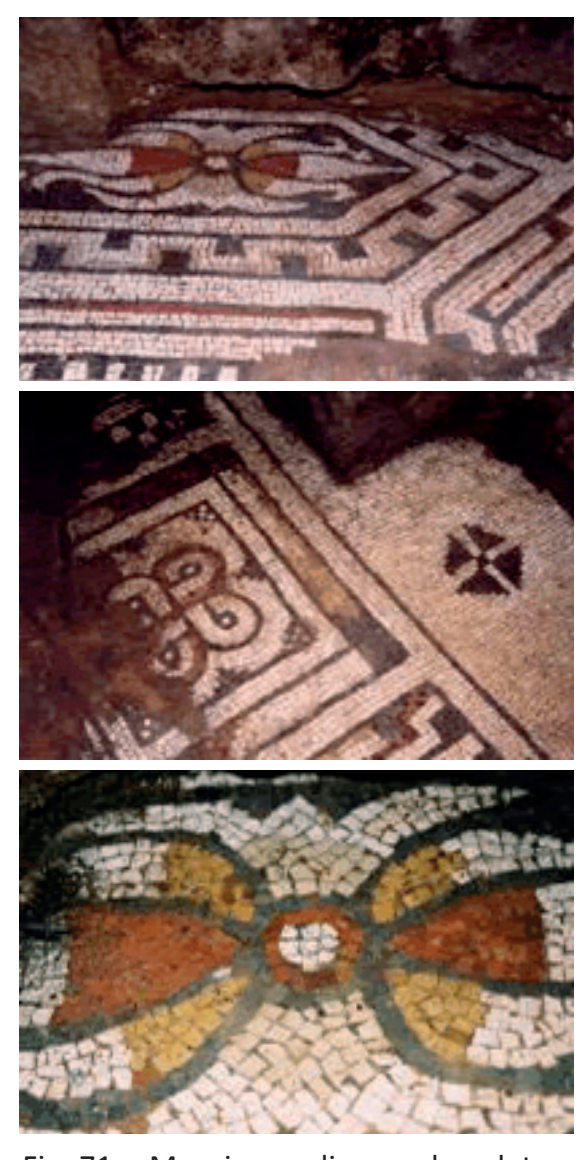

$71-$ Mosicos policromados, detecFig. 71 - Mosaicos policromados, detecde Santa Maria do Freixo.
Ver Tongobriga, Lino Dias, 1997, p. 32.

- Ver Os mosalcos da igreja de Sa,

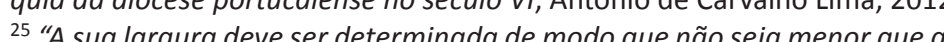

A A sua largura deve ser de respectivo comprimento, salvo se a no que a terça parte impedir o obrigar a fazer a proporção de outra maneira", Vitrúvio, V, 1, 4. Tradução de Justino Maciel.

${ }^{26}$ Ver: www.tongobriga.com.sapo.pt/basilica.html. 


\section{4 - Áreas Privadas. Zonas Habitacionais}

As habitações, mercados e lojas organizavam a maior parte do que era a cidade romana. Ao fundar uma cidade, era dada grande prioridade à sua construção, e feito previamente um plano de distribuição dos lotes.

Tongobriga, em comparação com outras cidades, seria uma urbe de médias dimensões, em que as áreas habitacionais ocupariam cerca de 10 hectares, indicando assim uma população de cerca de 2500 pessoas $^{1}$. Os vestígios de habitações obtidos, embora reduzidos, são bastante dispersos, o que permite afirmar que as zonas habitacionais eram vastas.

Os investigadores identificaram duas fases relevantes na arquitectura desta cidade. Identificaram uma primeira de um povoado de arquitectura castreja, com casas de planta circular e cobertura a colmo, construídas ainda em tempo de Augusto, no início I d.C.; e uma segunda, em época posterior à governação de Vespasiano, em que as casas castrejas foram desmontadas e sobre os espaços livres se construíram casas de arquitectura romana, incluindo domus com implúvio (impluvium) do tipo itálico ${ }^{2}$. Tanto numa fase como na outra, atribui-se a construção destas casas ao domínio romano (fig. 73).

Estes vestígios repartem-se essencialmente por duas zonas: um bairro na encosta poente, junto à actual igreja (fig. 74); e um conjunto na encosta nascente, junto aos vestígios da muralha (fig. 75). Para além destes dois focos das escavações, foram encontradas algumas secções de muros dispersos, um pouco por toda a aldeia (fig. 76).

Da fase correspondente à arquitectura de tipo castrejo os vestigios são escassos, resumindo-se aos talhes circulares e a uma cavidade central que serviria para um suporte à cobertura de colmo. Embora estes sejam atribuídos a um período de domínio romano nesta região, é-nos mais interessante explorar a fase de arquitectura romana.

Nas casas da encosta poente, encosta em que são dominantes as construções flavianas e do século II, denota-se a preocupação de respeitar uma ortogonalidade, tendencialmente norte/sul e este/oest (ângulo $2^{\circ}$ ). Essa preocupação é sentida especificamente no traçado das ruas que envolviam as domus de planta tradicional; algumas delas servidas de implúvio central, abastecimento de água e esgotos.

$\mathrm{Na}$ encosta nascente, as áreas escavadas situam-se junto muralha, e os poucos muros existentes apresentam alguma ortogo-

Ver Tongobriga. Breves Reflexões, Lino Dias, 2003, p. 19

Ver Sintese Tongobriga (texto em edição), Lin。
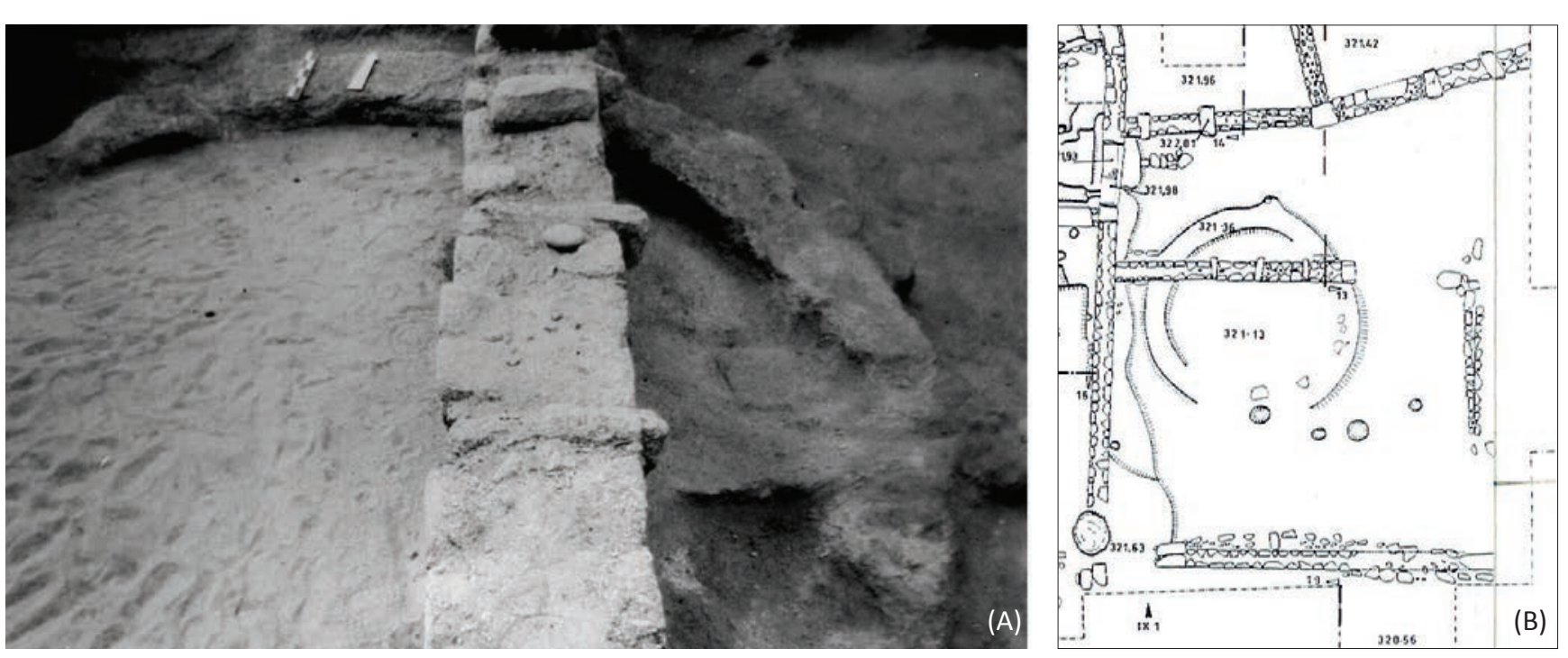

Fig. $73-$ Uma
(A). Planta (B)
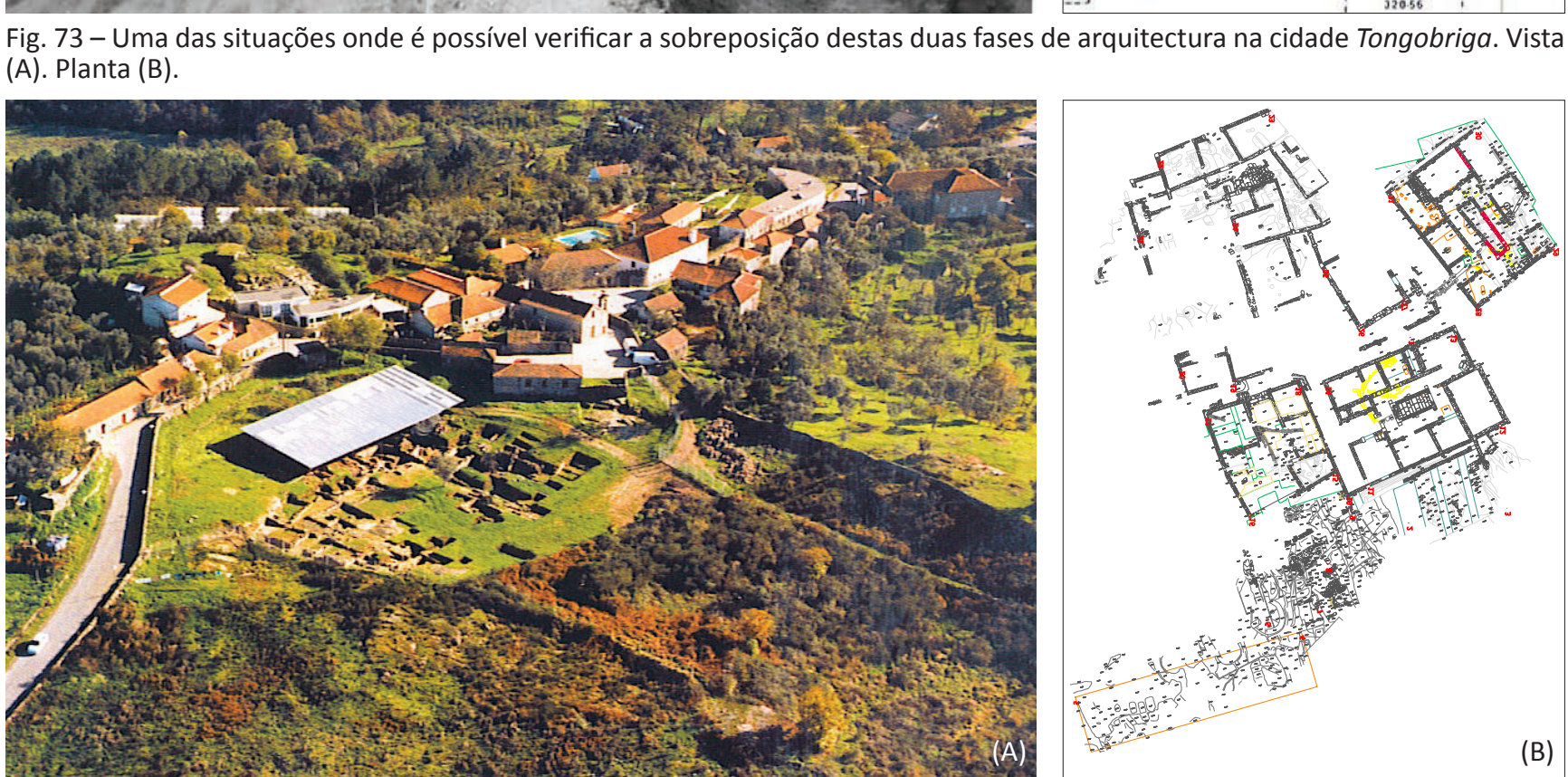

Fig. 74 - Conjunto habitacional poente. Vista aérea (A). Planta (B).
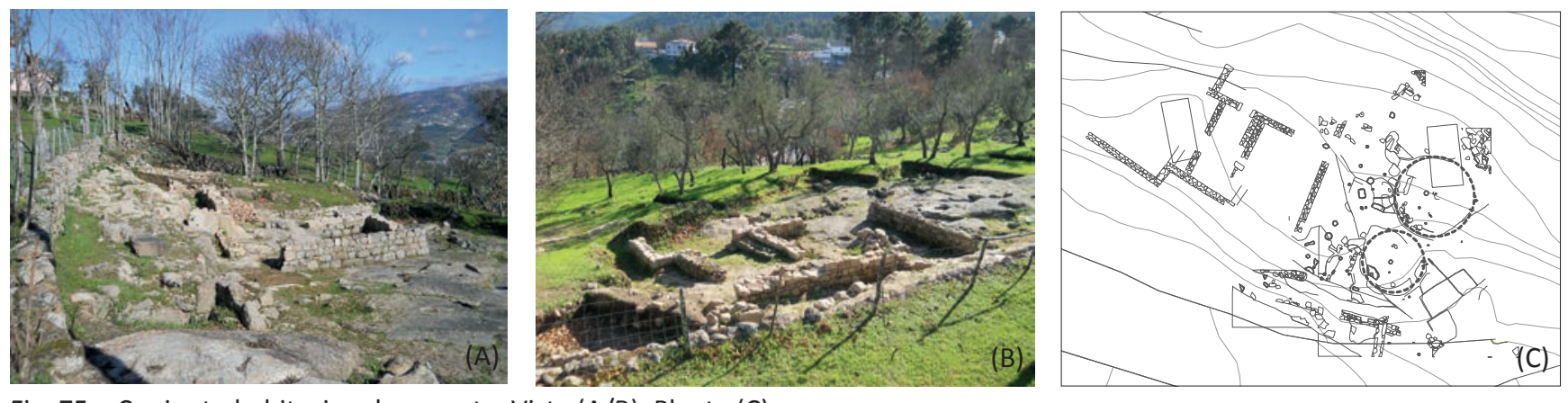

Fig. 75 - Conjunto habitacional nascente. Vista (A/B). Planta (C).
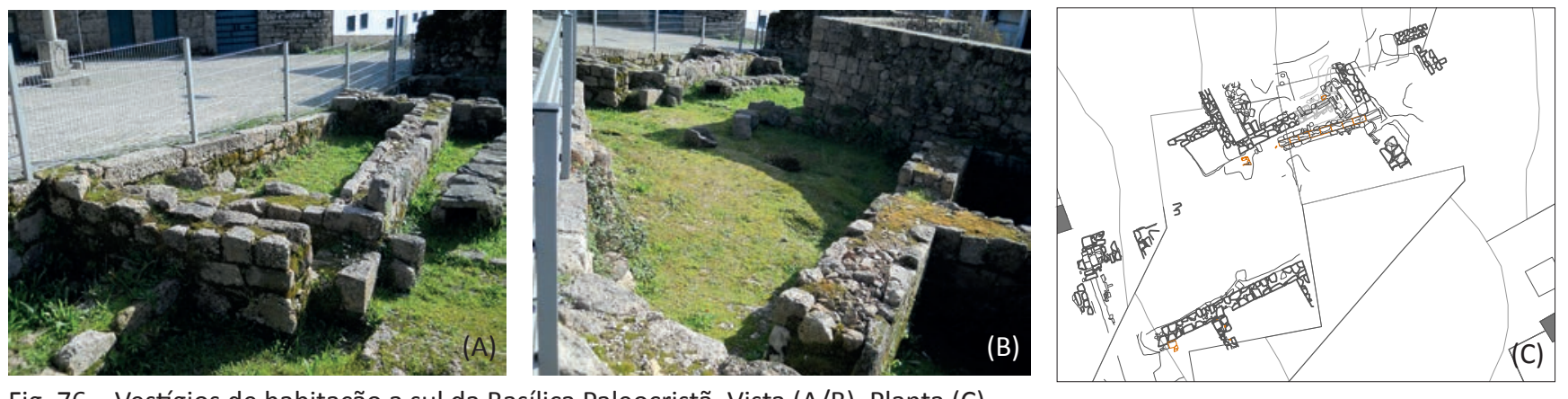
nalidade entre si. Mas, uma vez vistas em conjunto com as restantes ruínas, estas dispõem-se numa outra direç̧ão que não a do resto da cidade, rondando numa diferença de cerca de $45^{\circ}$.

Relativamente aos restantes vestígios habitacionais, exumados em diversos sítios da aldeia, reconhecem-se alguns alinhamentos de possíveis eixos, que mostram a manifesta ortogonalidade do urbanismo de Tongobriga ${ }^{3}$

No núcleo da encosta poente, que tem maior área de vestígios, é possível identificar o traçado de algumas ruas, e reconhecer alguma individualidade nas habitações. Assim, foi possível denominá-las da seguinte forma: Casa do Poço, Casa do Impluvium, Casa das Escadas e uma zona de domus (fig. 77$)^{4}$.

Por se tratar de um caso relevante, descreve-se aqui a Casa do Impluvium, tendo em conta a sua construção de tipo itálico (fig. 81) fortemente guiada pelos preceitos vitruvianos.

\section{Casa do Impluvium}

O seu nome, Casa do Impluvium, advém precisamente de esta ser, até ao momento, a única casa em Tongobriga cujos vestígios comprovam a existência de um implúvio e dos preceitos descritos por Vitrúvio para a casa romana. Esta implanta-se segundo as orientações dominantes na cidade $\left(24^{\circ}\right)$ e tem uma área bruta de cerca de $330 \mathrm{~m}^{2}$ (figs. 78, 79, 80 e 82).

Esta casa não chega a respeitar na sua totalidade os preceitos vitruvianos, pois não chega a ter alas (alae) ou tablino (tablinium); mas no que diz respeito ao átrio (atrium) e à forma de se entrar na casa, adopta todas a indicações.

O átrio ${ }^{5}$ era ponto fulcral da casa, pois tratava-se da maior fonte de luz para todos os compartimentos 6 . Este conforma-se num espaço de 33 pés de comprimento por 22 de largura, correspondendo assim

${ }^{3}$ Ver Tongobriga. Breves Reflexões, Lino Dias, 2003, p. 19

${ }^{4}$ Nomes atribuídos pelo Lino Dias em Tongobriga. Breves Reflexões, 2003, p. 85. 5 "Os átrios das casas distinguem-se em cinco tipologias: toscano, corintio, tetrastito, displuviado e testudinado. Os toscanos são aqueles nos quais as traves dispostas no sentido da largura do átrio têm pranchas e telhas que correm das esquinas das paredes ate aos ângulos dos vigamentos, sendo assim lançadas as águas das chuvas sobre o ripado na direç̧ão central do compluvio. Nos corintios, colocam-se da mesma feiçẫo as traves e os compluvios, mas as vigas que saem das paredes apoiam-se sobre colunas dispostas em volta. Os tetrastilos saio os que possuem colunas angulares sob as submetidas a uma grande carga nem são oneradas pelas pranchas". Vitrúvio, Ví, sä Tradução de Justino Maciel. ${ }^{6}$ As domus romanas tinha rua e da sua confusão. Sendo o pátio a sua maior fonte de iluminação.

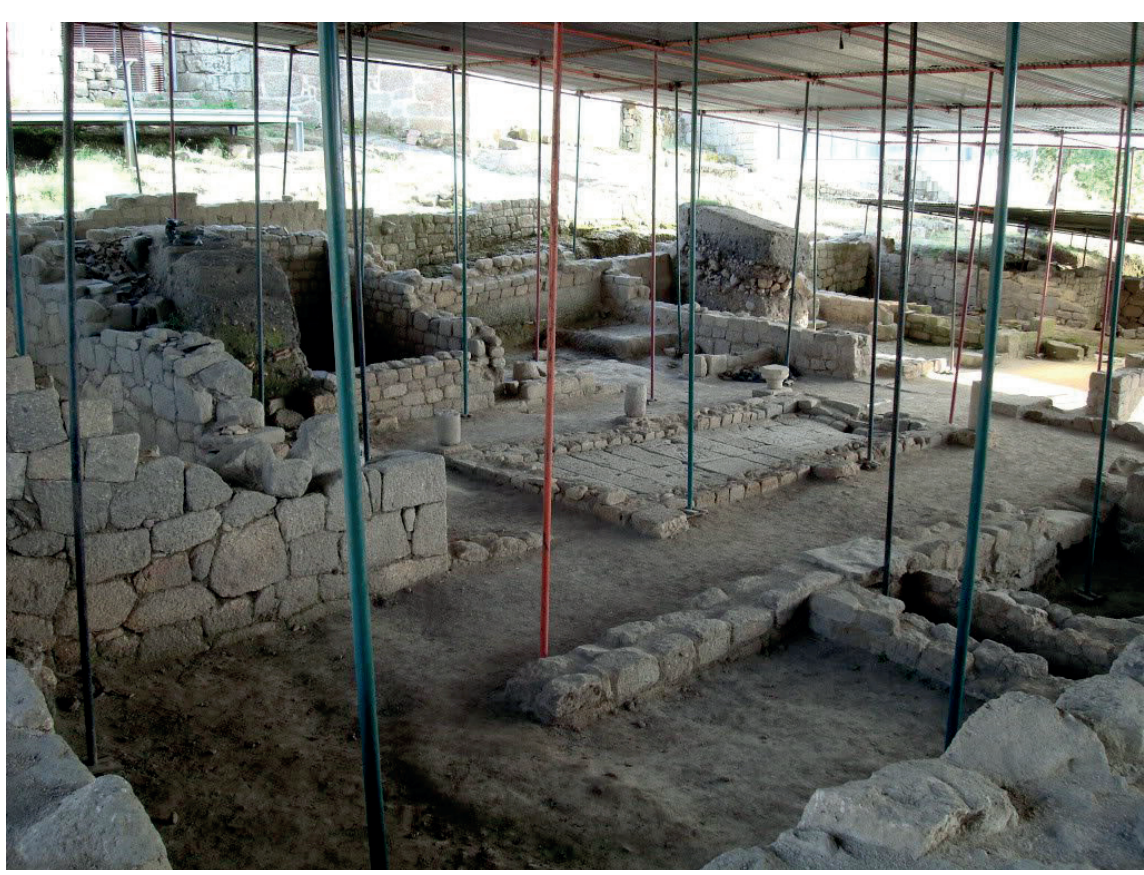

Fig. 78 - Casa do Impluvium.

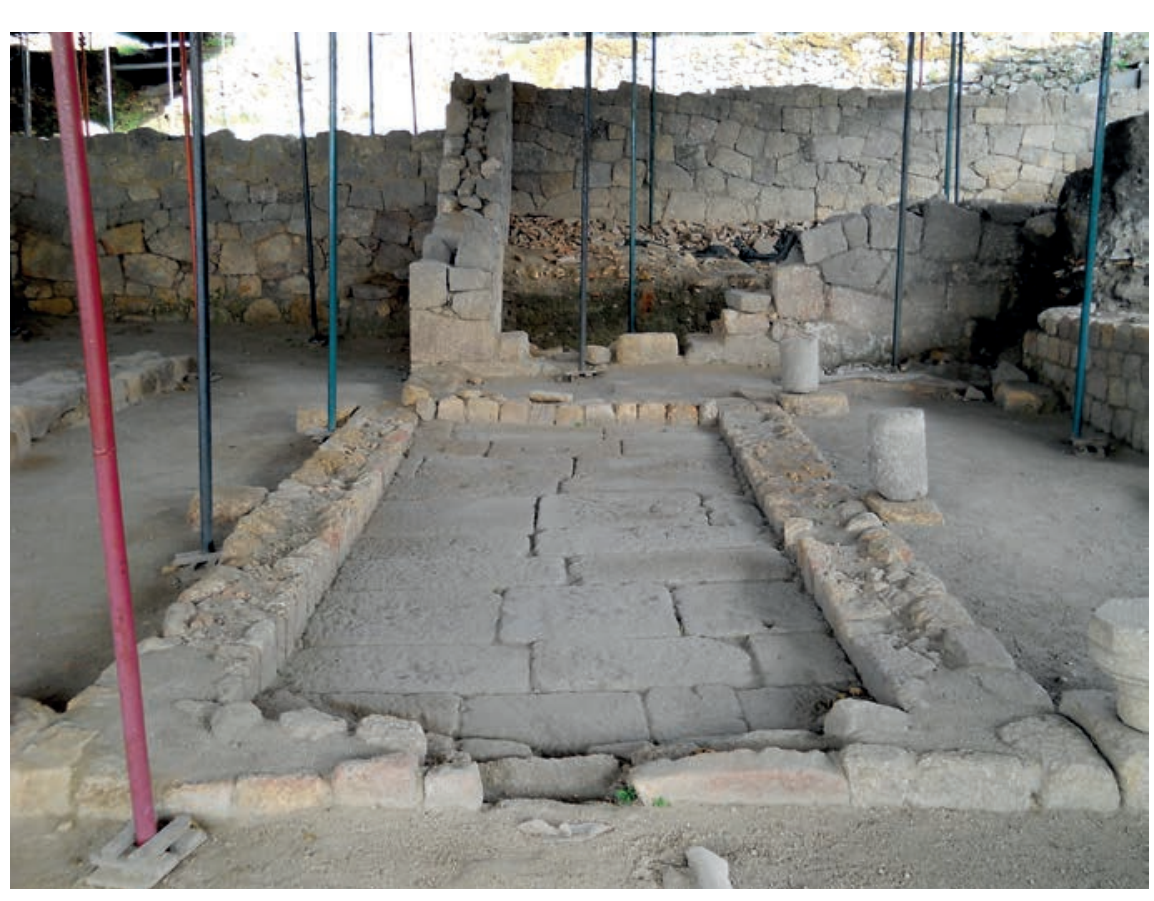

ig. 79 - Casa do Impluvium. Implúvio com pavimento granítico.

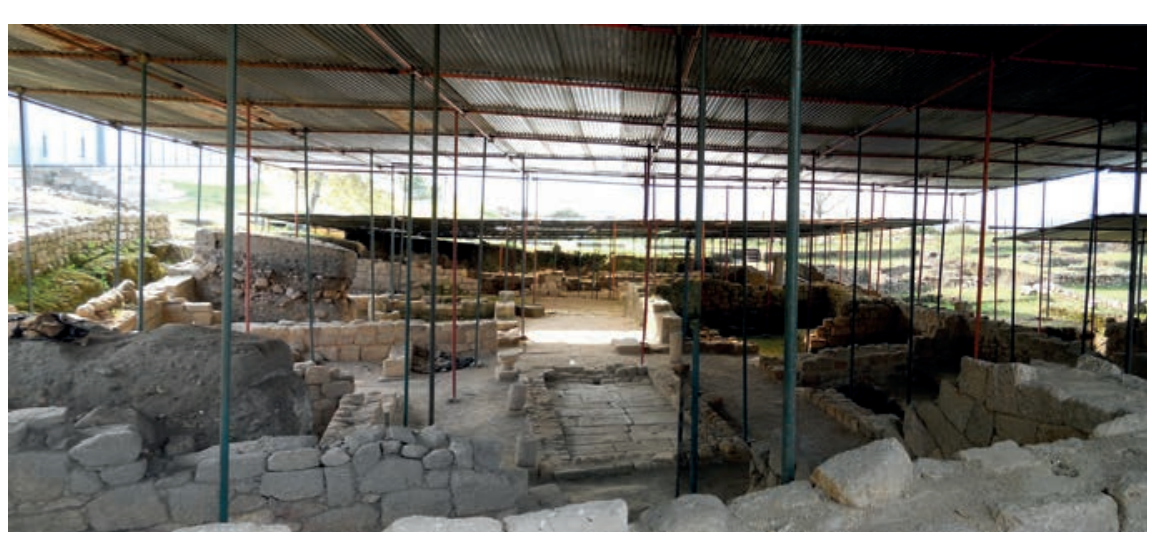

Fig. 80 - Casa do Impluvium. Vista no sentido poente.
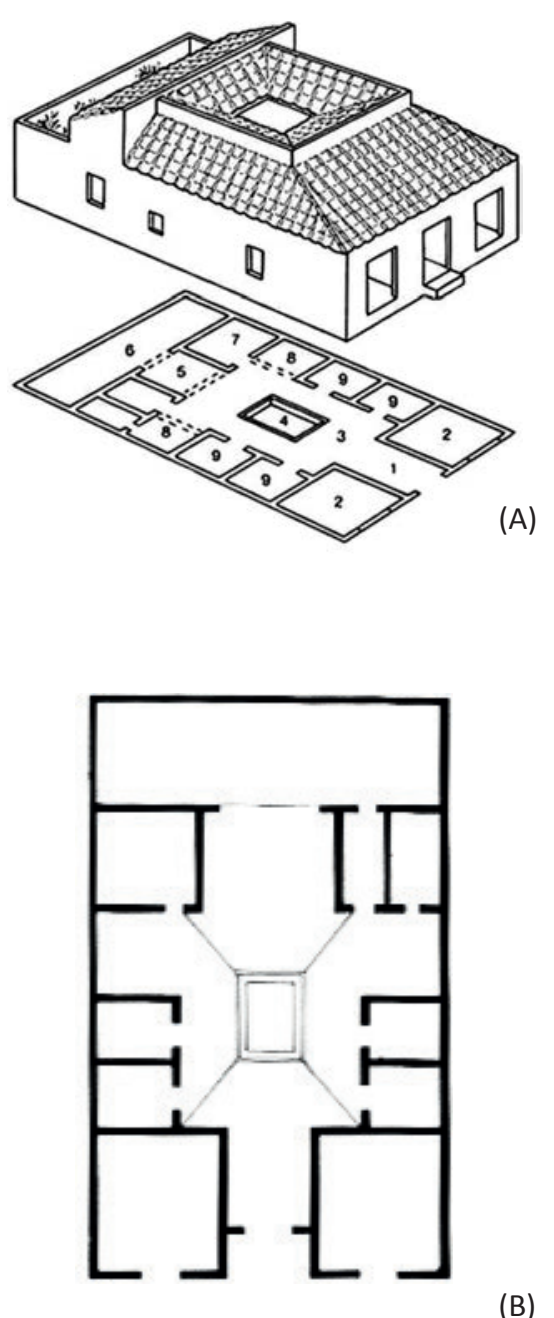

(B)

Fig. 81 - Domus itálica.

(A) - representação axnométrica. (B) - planta.

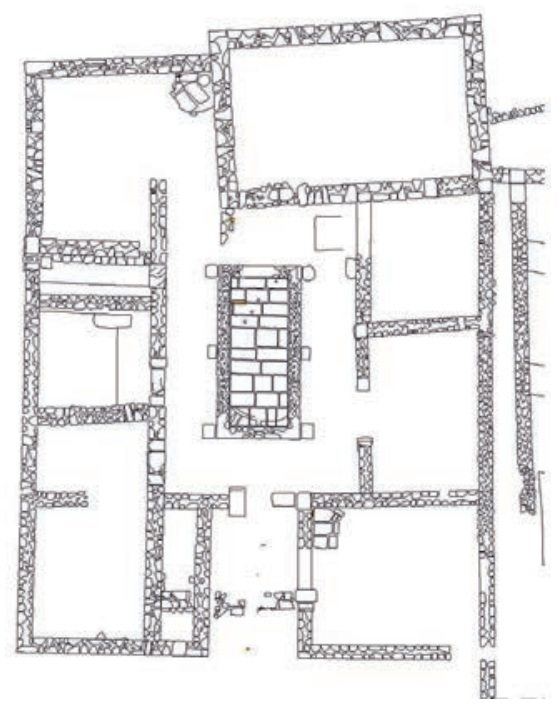

Fig 82 - Casa do Impluvium Plant 
à descrição proporcional de dois terços ${ }^{7}$. No centro do átrio estava o implúvio, um espaço aberto ao ar livre, que recolhia as águas pluviais para abastecer um tanque subterrâneo. Na cobertura corresponderia a um complúvio (compluvium) ${ }^{8}$, que deixaria passar a luz e as águas das chuvas (fig. 83). A suportar as vigas que configuravam o complúvio estavam seis colunas, de ordem dórica.

Na Casa do Impluvium, em Tongobriga, não se verifica a existência de alas. Apenas se verifica a presença dos cubículos (cubicula), pequenos quartos de repouso que ladeavam o átrio. Do lado esquerdo do átrio, encontram-se três compartimentos que têm sensivelmente um terço do comprimento do átrio, correspondendo aos preceitos de Vitrúvio. Mas o mesmo não acontece do lado direito, pois só se encontram dois compartimentos, de larguras distintas (fig. 84).

A largura e o comprimento dos atrios regulam-se de três maneiras. A primeira con siste em dividir o comprimento em cinco partes e dar trés á largura; a segunda, em dividi-lo em tres par tes earnbuir duas a esta, a tercelia, em descrever um quadrado com os o comprimento dessa linha ao do átrio". Vitrúvio, VI, 3, 3. Traducão de Justino Maciel. 8 "A abertura do complúvio não ficará com menos do que um quarto da largura do átrio nem mais do que um terco: o compartimento será proporcional ao átrio". Vitrúvio, $V$ 3, 6. Tradução de Justino Maciel.

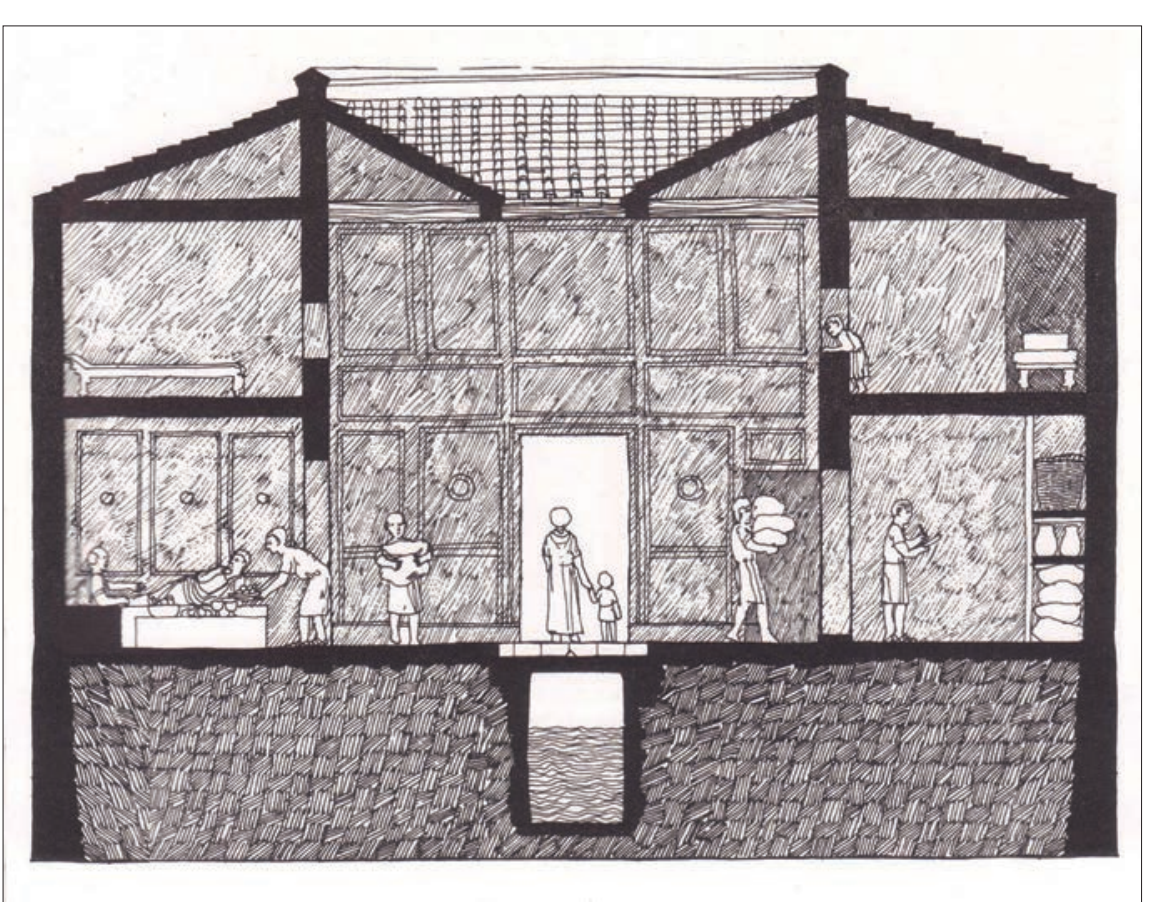

Fig. 83 - Desenho de um corte tipo de uma casa romana itálica. Desenho de

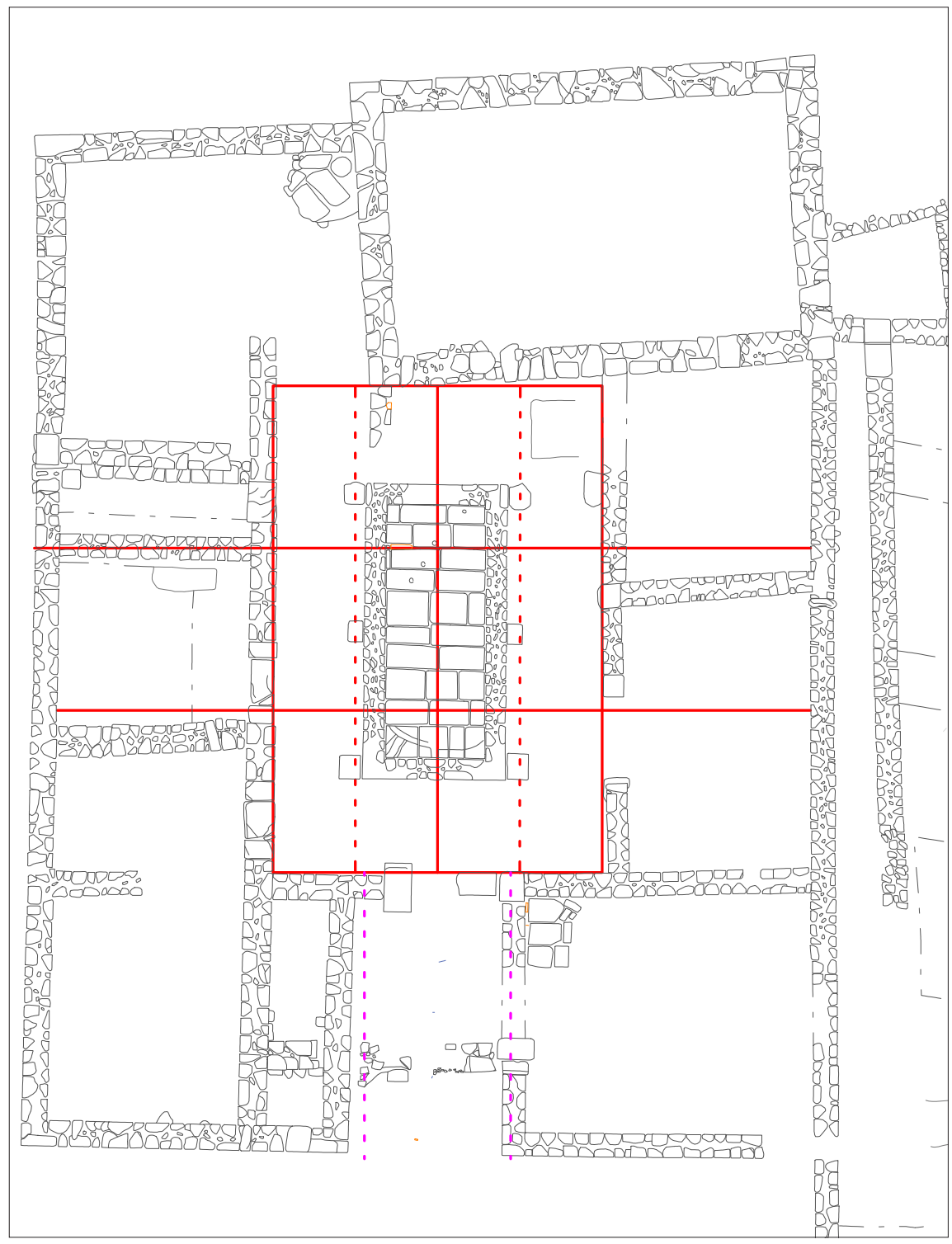
com a aplicação das dimensões propor-
cionais indicadas por Vitrúvio.
Fig. 84 - Planta da Casa do Impluvium, 


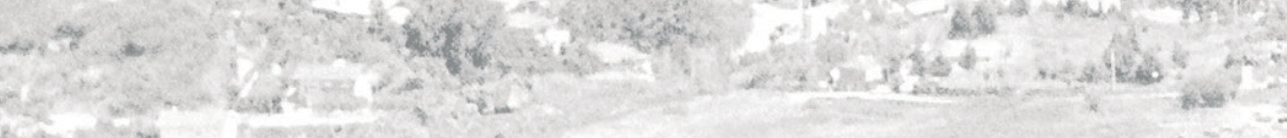

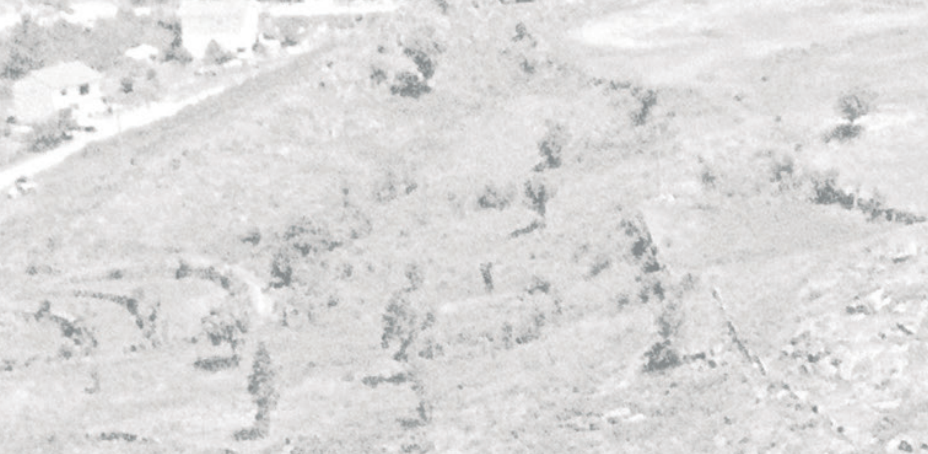

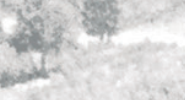

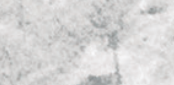

$+4$

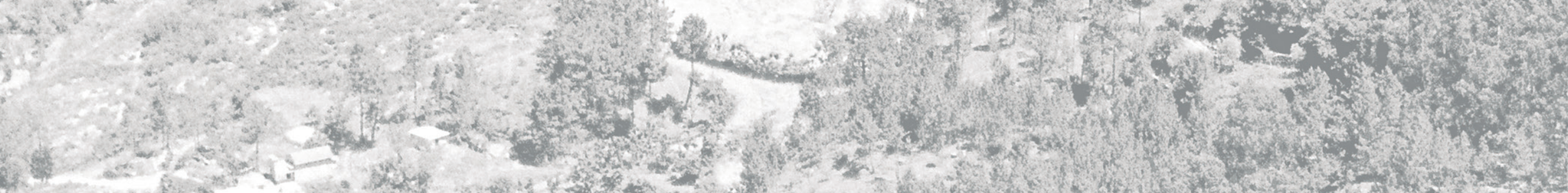

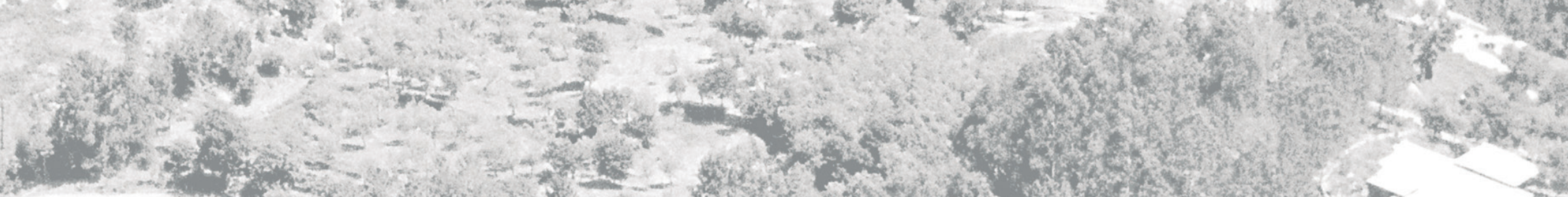

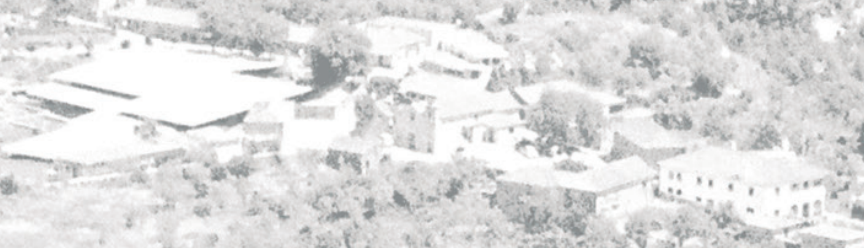

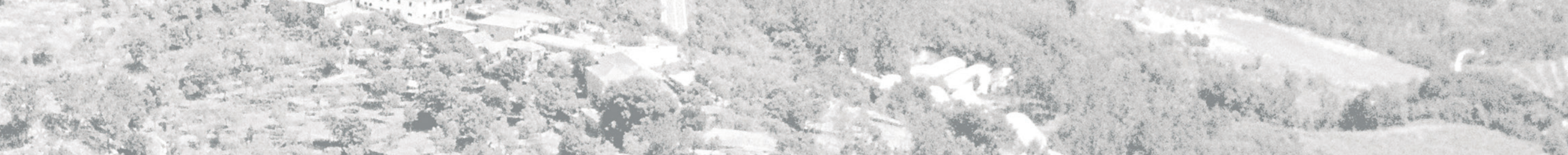

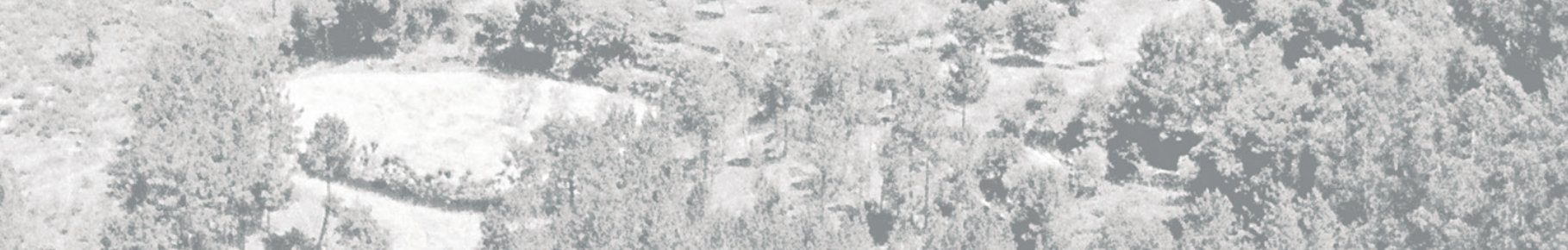

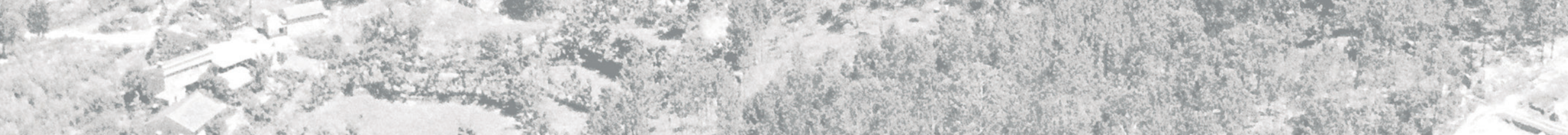

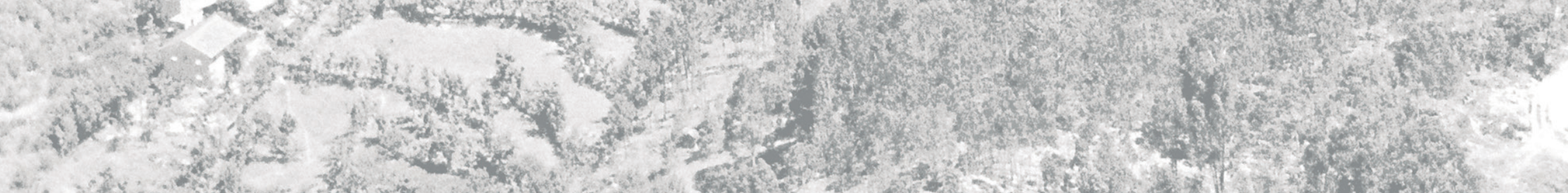

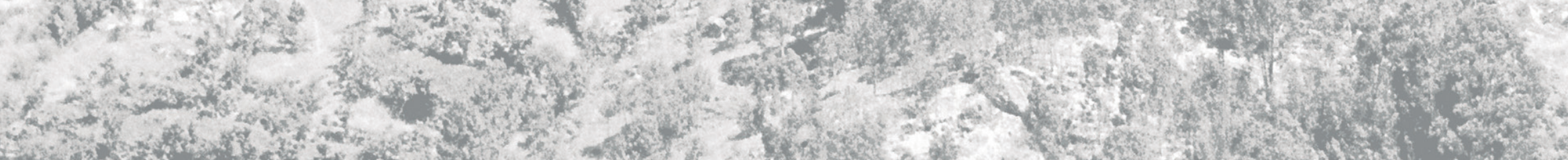

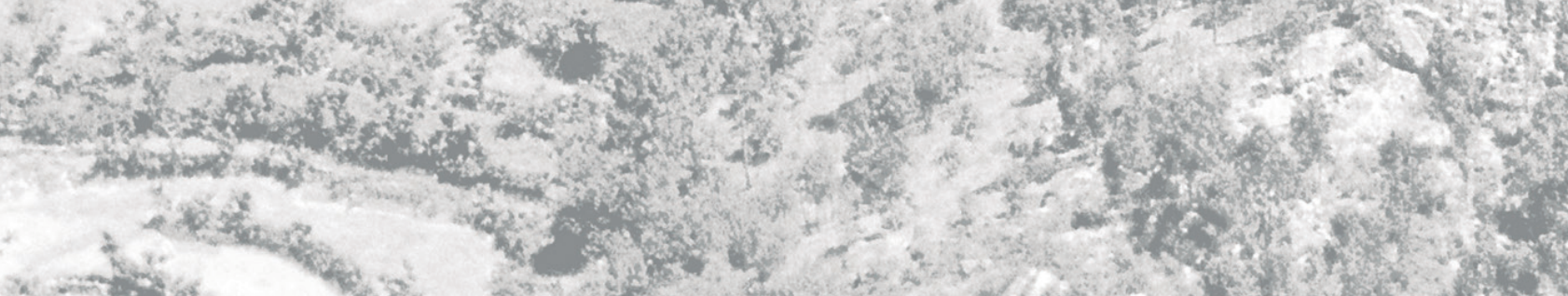




\section{1 - A Cidade Romana}

\subsection{1 - Compreensão da estrutura}

Numa investigação cujo objectivo foi a reconstituição desenhada do centro cívico de Tongobriga, achou-se pertinente uma primeira análise da estrutura desta antiga cidade romana.

Devido a equipamentos, como é o caso do teatro, em que a falta de elementos dificulta o seu redesenho bem fundamentado sentiu-se a necessidade de procurar pistas na envolvência. Elementos que ajudassem a fundamentar o seu desenho; uma regra, um cânone algo que pudesse ajudar à compreensão do seu enquadramento na cidade.

Esta forma de pensar vai muito ao encontro da forma como os romanos planearam a sua cidade. Como referido ${ }^{1}$, estes eram defensores de uma cidade bem planeada, que estaria disposta segundo uma grelha, e organizada segundo uma disposição regular de ruas e quarteirões. Ao observarmos a planta de Tongobriga, a tendência ortogonal é bastante patente nos seus vestígios, especialmente no espaço do centro cívico².

Assim, entendeu-se pertinente explorar esta vertente da investigação. Este estudo das ruínas existentes, a uma escala de cidade, de urbanização, permitiu chegar ao que aparentemente é o quadriculado que estruturou toda a cidade de Tongobriga.

Para se chegar a este dado de extrema importância na análise da cidade muitos foram os factores que auxiliaram a esse raciocínio.

Nesta perspectiva urbana, Lino Tavares Dias apontou uma hipótese de estrutura, no âmbito de um encontro, Actas de Mesa Redonda. Emergência e Desenvolvimento das Cidades Romanas no Norte da Península Ibérica, em 1999. Aí foi demonstrada (e é possíve ver na publicação ${ }^{3}$ ) uma figura onde é testada a sobreposição de uma grelha, na zona habitacional. Esta grelha tomava por base a orientação e dimensão da zona de domus ou potenciais insulae no núcleo habitacional poente, e alastrar-se-ia de forma geral pelas zonas habitacionais (fig. 85).

${ }^{1}$ Ver Urbanismo e Organização, p. 48

2 "A partir de algumas ruínas exumadas em diversos sitios da aldeia, reconhecemos alguns allinamentos de possiveis eixos que mostram manifesta ortogonalidade ${ }^{3}$ Ver "A urbanizaç̃o do noroeste peninsular: O caso de Tongobrisa", in Actas da Mes Redonda. Emergência e Desenvolvimento das Cidades Romanas no Norte da Peninsula Ibérica, Lino Tavares Dias, 1999, p. 103.

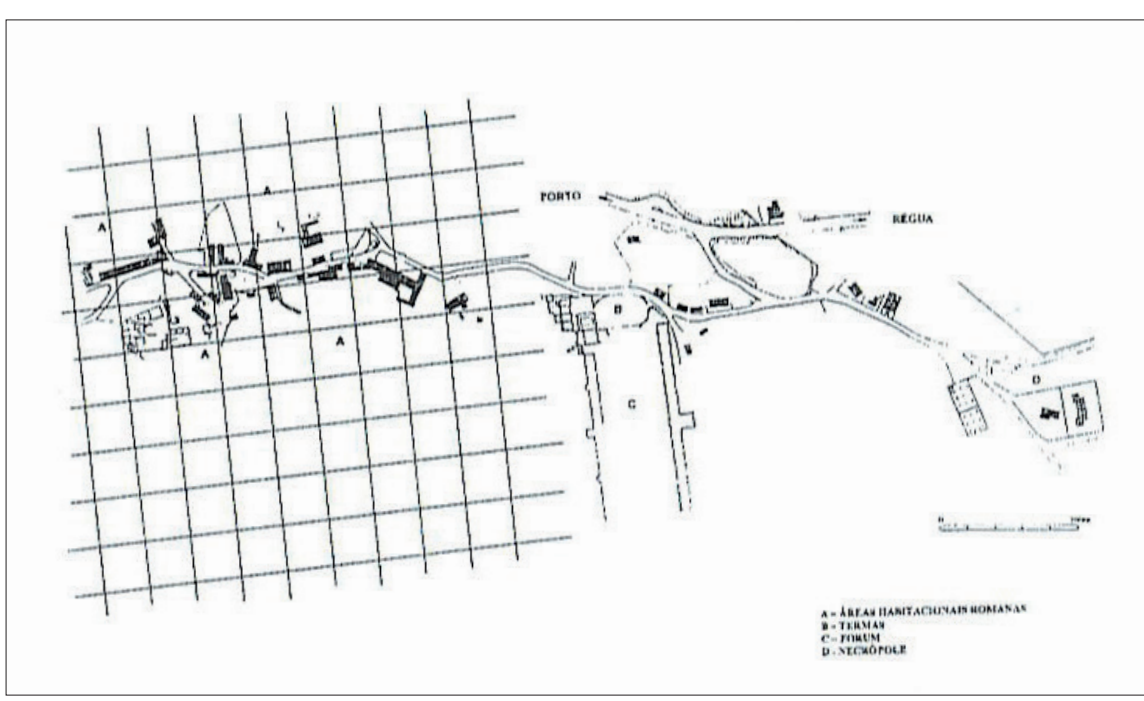

ig. 85 - Figura onde se demonstra uma hipótese de estrutura da zona habita-

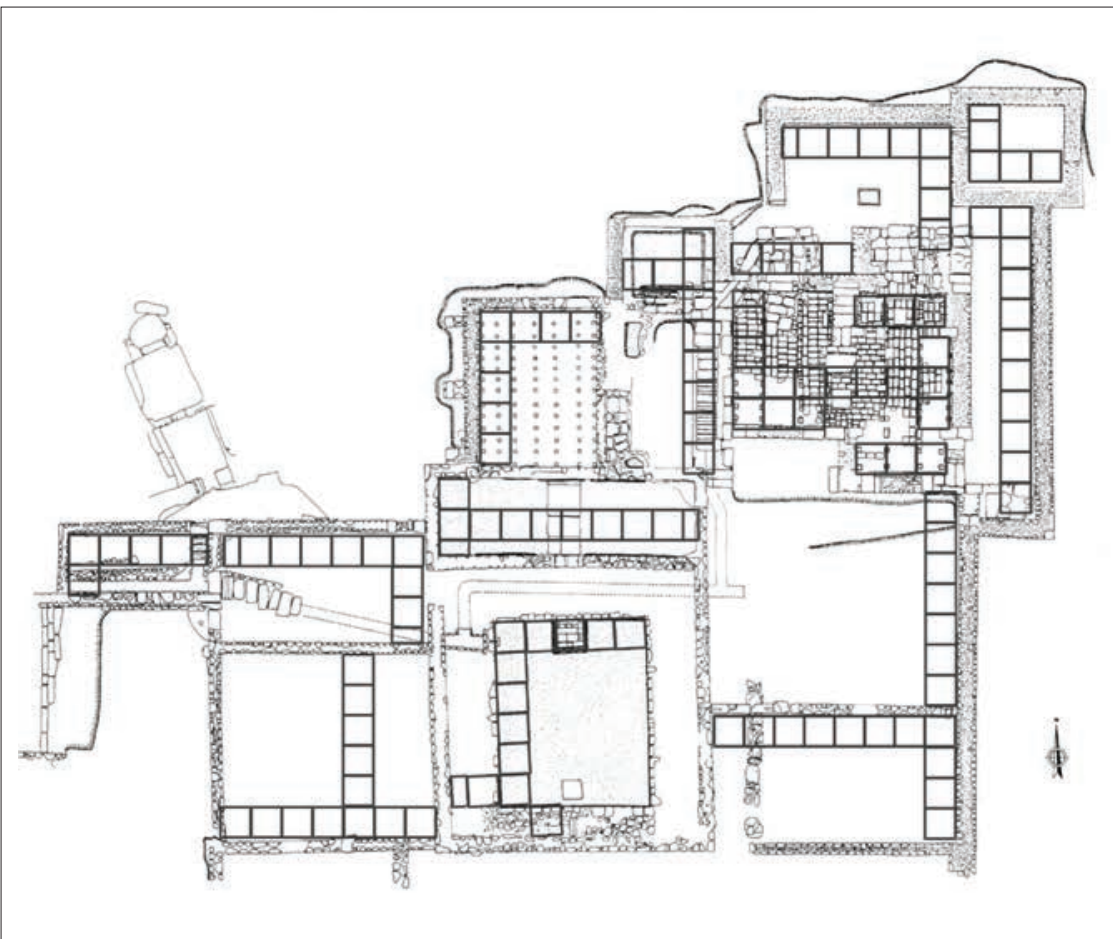

Fig. $86-A$
termas.

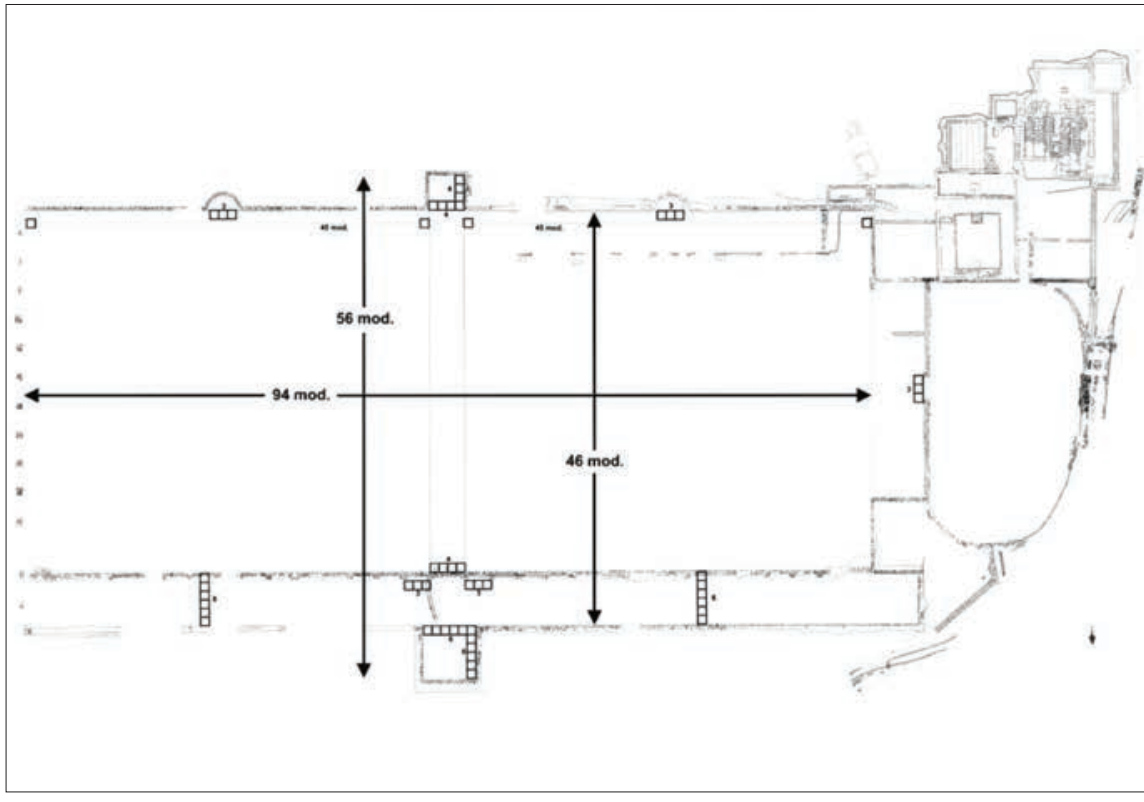

fo. 87 - Aplicação do módulo passus no forum 
Também por Lino Dias foi apontado o uso da unidade de medida passus, cuja aplicação se demonstra relevante no desenho dos edifícios públicos do centro cívico, nomeadamente nas termas (fig. 86) e no forum (fig. 87). Esta unidade corresponde a dimensões de $147,9 \times 147,9 \mathrm{~cm}$ Um passus romano corresponde a cinco pés (pes) , $^{4}$ sendo, portanto este módulo de cinco por cinco pés romanos (fig. 88).

Quando comparada com outras cidades, Tongobriga demonstra maior afinidade com Bracara Augusta; cidade que se salienta pela sua proximidade com Tongobriga. Ao interpretar Bracara, cruzou-se com uma referência sobre a sua organização urbana.

Manuela Martins explica que:

"A modelação identificada nos inícios dos anos 90 (Martins Delgado 1989/90), possui eixos orientados NO/SE, estruturando quarteirões de forma quadrada, com aproximadamente 150 pés de lado, entre o eixo das ruas e áreas construídas de 1 actus (120 pés). Evidente na área arqueológica das Carvalheiras, onde se situa o exemplar melhor conservado da habitação urbana de Bracara Augusta, esta modelação tem vindo a ser verificada noutros sectores escavados, designadament no terreno onde se situa o antigo Albergue Distrital e na Colina do Alto da Cavidade"s (fig. 89).

O conhecimento das dimensões da insula tipo em Bracara Augusta, em conjunto com a modelação passus, permitiu chegar a um quadriculado que se ajusta à cidade de Tongobriga.

Neste sentido realizaram-se ensaios, usando como base os equipamentos públicos situados no centro cívico; pois, dada a sua maior dimensão e regularidade ortogonal face aos restantes vestígios, permitiam um maior rigor na implementação de um quadriculado.

Assim, entendeu-se que Tongobriga teria uma modelação base de 120 por 120 pés romanos (fig. 90)

Fig. 88 - Esquema de passus.
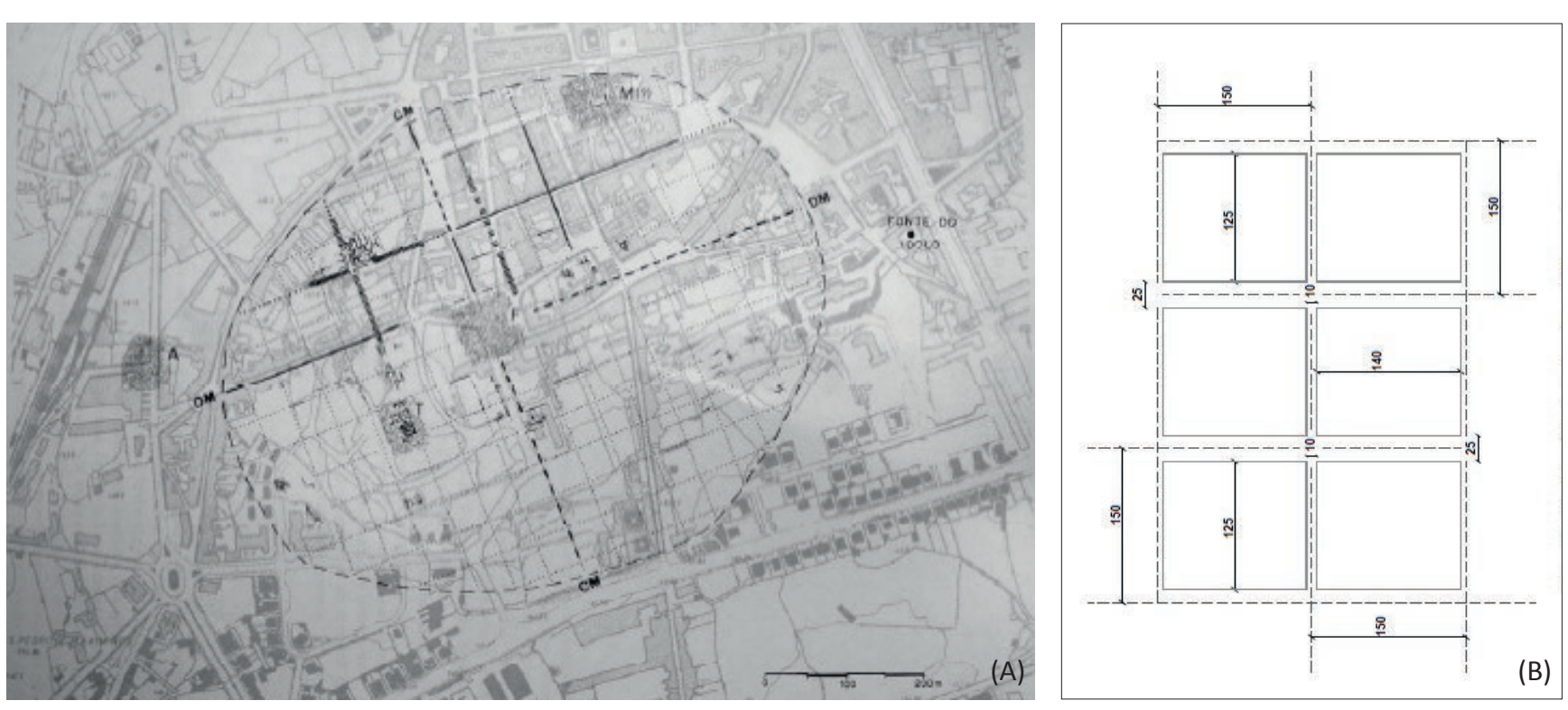

fig. 89 - (A) Bracara Augusta. Planta da estruturação pela grelha $150 \times 150$ pés. (B) Modelo teórico da malha de Bracara Augusta.
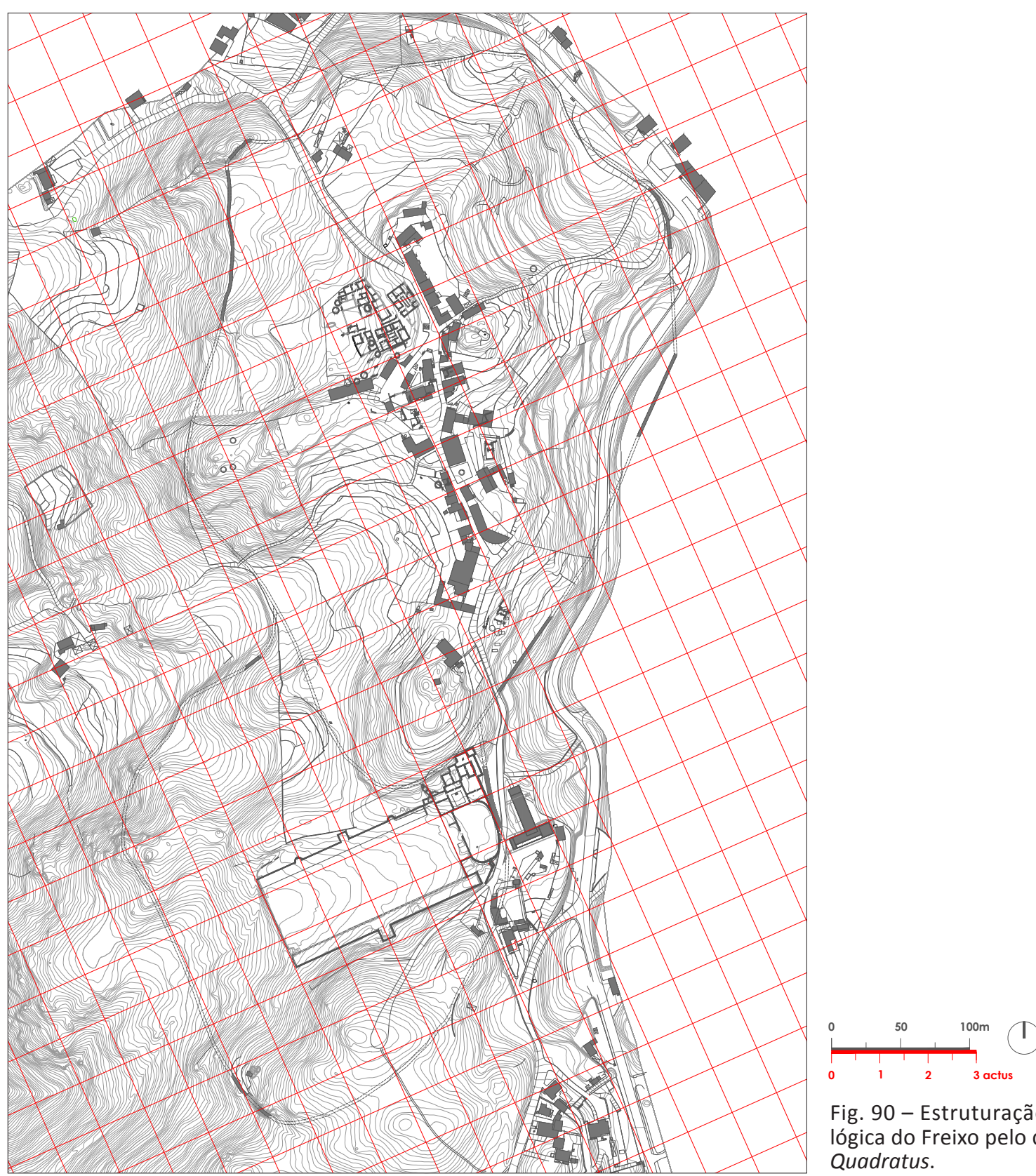

Assim, toma-se conhecimento da unidade de pé na cidade de Tongobriga, sendo un pé equivalente a $29,58 \mathrm{~cm}$.

in Actas da Mesa "A donda Eşara do noroeste peninsular. O caso de Bracara Augusta" Norte da Peninsula lbérica, 1999, p. 59 .

(Dendo Bracara Augusta capital do conventus segundo uma grelha de dimensões e orientação similares. ig. 90 - Estruturação da Área Arqueologica do Freixo pelo quadriculado Actus 


\subsection{2 - Actus Quadratus}

A medida de 120 pés a que se chegou corresponde à unidade do actus do sistema métrico romano. Trata-se de uma medida que era muito usada pelos agrimensores romanos na divisão agrária, e que formava a base de toda a medição territorial. 0 actus quadratus corresponde à unidade quadrada do actus; e esta unidade, por sua vez, servia de base para a definição de uma centúria (20 por 20 actus -400 actus quadratus) (fig. 91).

Era hábito, com o auxílio de uma groma, os agrimensores romanos efectuarem a divisão de terras ao longo de dezenas e dezenas de kilómetros, através do processo de centuriação (fig. 92 e 93$)^{7}$.

$\mathrm{O}$ actus e o actus quadractus foi descrito por William Smith da seguinte forma:

"ACTUS, uma medida romana de terras, que formou a base de todo o sistema de medição territorial. Nesse sistema o nome, actu (de outrora), que originalmente significava um caminho entre dois campos para o carro de boi passar (ou, como alguns dizem, o com primento de um sulco), era dado para tal caminho aquando de uma largura e comprimento definitivos, e também a um pedaço quadrado de terra do mesmo comprimento. O primeiro foi chamado de actus minimus ou simplex, e tinha 120 pés (romanos) de comprimento por quatro pés de largura (...) $\mathrm{O}$ actus quadratus, que era a unidade quadrada no sistema de medição territorial romano, era do mesmo com primento que $o$ actus minimus, e de uma largura igual ao seu comprimento: era assim um quadrado de 120 pés (de lado), e continha 14.400 pés quadrados. Este era a metade de uma jugerum (...) $O$ actus fornece um exemplo do uso do número doze entre os romanos, sendo o seu comprimento doze vezes o decempeda padrão. Columella (...) diz que os gauleses chamavam o actus quadratus, aripennis; mas isso só poderia ser uma identificação aproximada, pois o actus quadratus é um pouco menor do que o grande arpent francês e muito maior do que $o$ arpent pequeno. (...)"

Para mais informação sobre o uso da groma, assim como sobre o modo como se rea lizava o processo de centuriação, ver: La Construcción Romana. Materiales y Técnicas, Jean Pierre Adam, 2002, pp. 9-13.

m Smith A Dictionary of Greek and Roman Antiquities, 1870, p. 13. Disponive para consulta em: http://www.ancientlibrary.com/smith-dgra/0020.htm

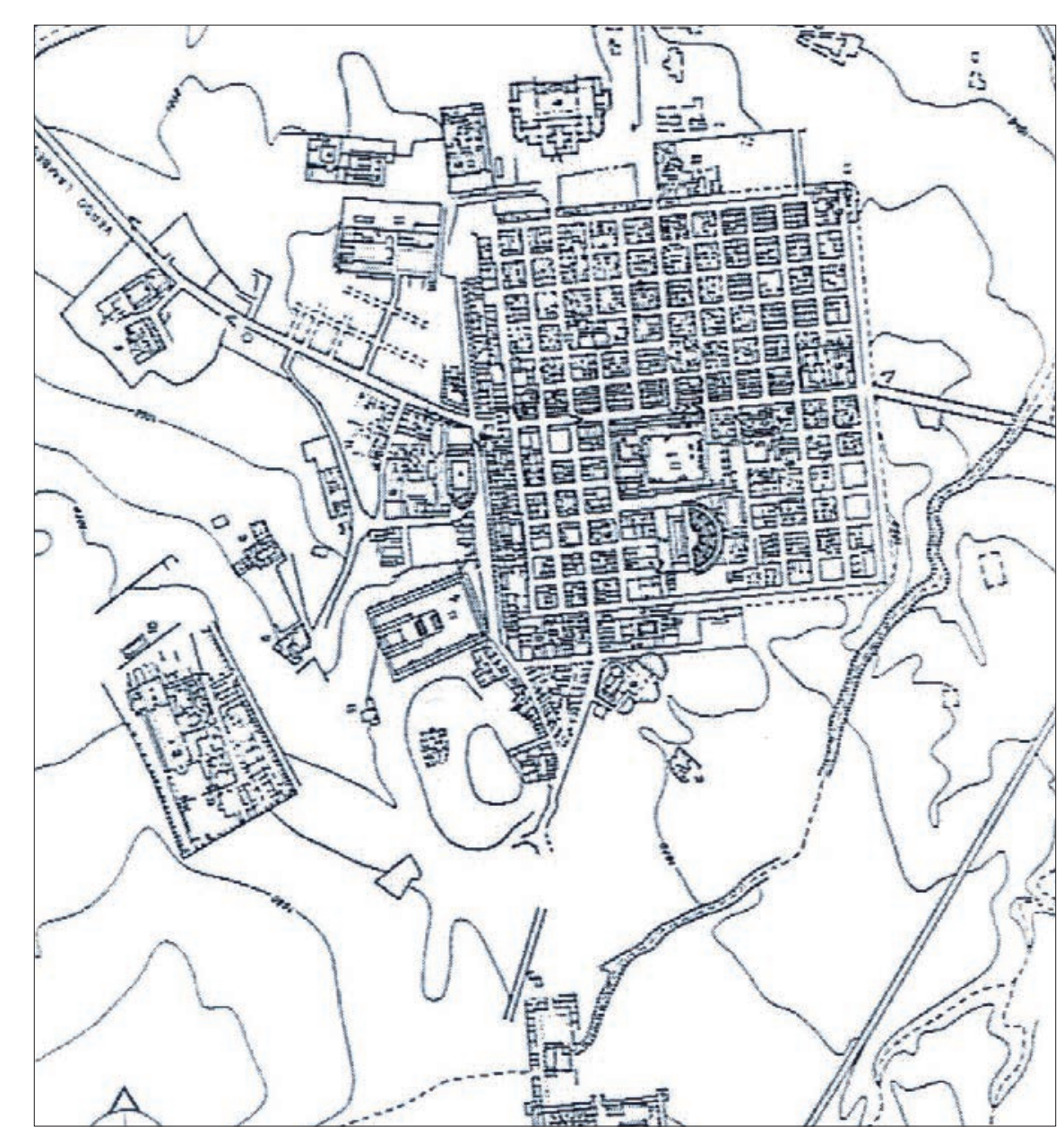

Fig. 92 - Timgad (Argélia), exemplo de divi-

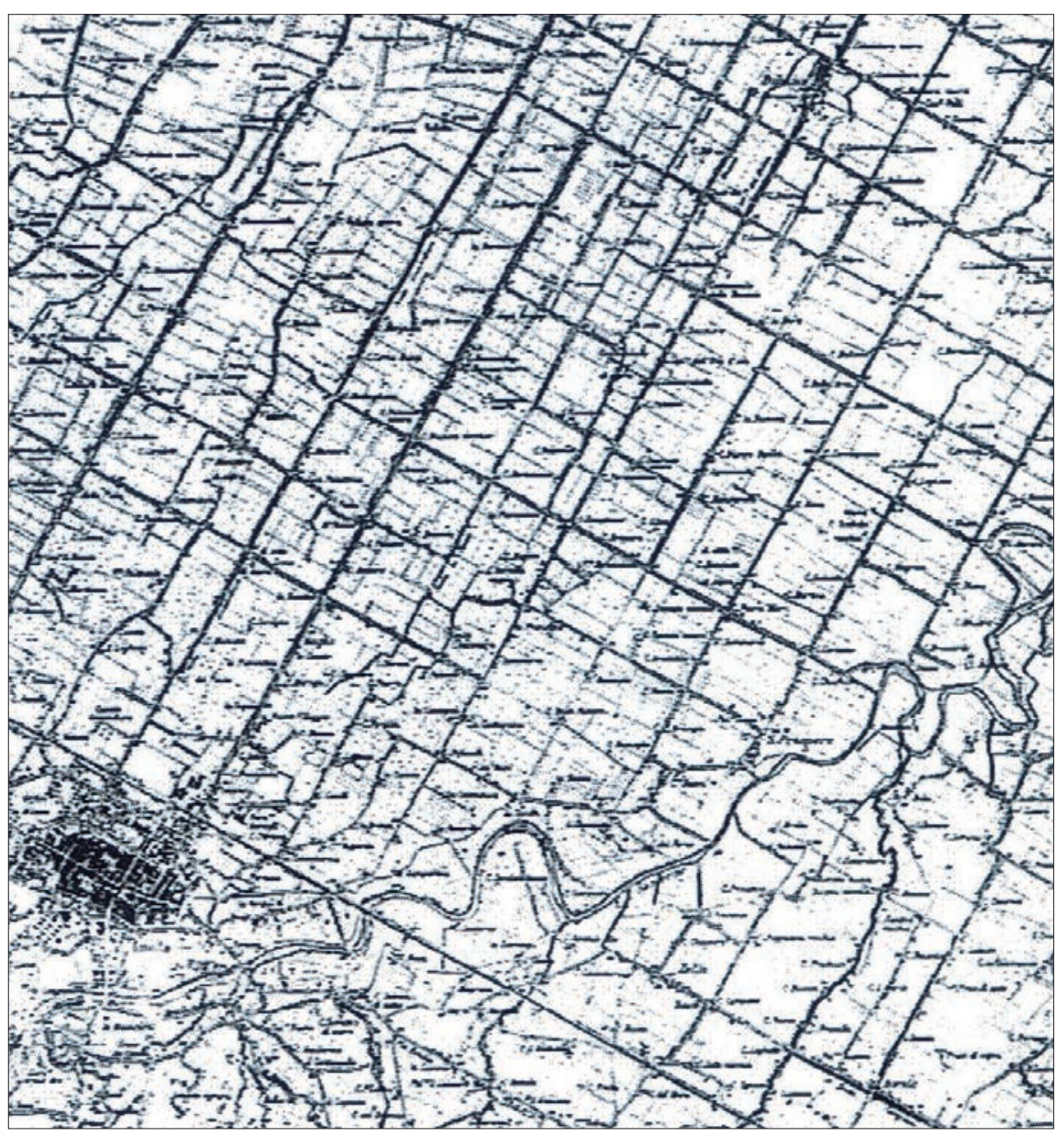

Fig. 93 - Mapa da região de Imola (Forum Cornelli), atravessada pela Via Emilia, sobre săo da antiga centuriação. 


\subsection{3 - Elementos coincidentes}

Neste ponto da investigação pretendeu-se demonstrar as potencialidades que este quadriculado apresenta, quer na compreensão das ruínas romanas quer na descodificação de elementos contemporâneos que de alguma forma terão preservado elementos da antiga cidade.

\section{Elementos romanos}

Ao sobrepor a grelha proposta sobre os vestígios romanos, manifestam-se as primeiras coincidências (fig. 94). Em primeiro lugar, torna-se mais evidente o paralelismo e a igualdade de orientação da maioria dos vestígios a descoberto, revelando-se desta forma possíve uma leitura global da cidade. Mas onde a sua aplicabilidade é especialmente relevante é na forma como o conjunto das termas e forum se insere neste quadriculado.

Este conjunto é a peça que melhor fundamenta o uso do actus em Tongobriga, pois permite a percepção da proporção, orientação e enquadramento das estruturas, sendo por essa razão considerada (numa primeira fase para efeitos desta investigação) o ponto de origem para a fixação e alastramento da quadrícula sobre a res tante cidade.

A grelha enquadra-se na cidade da seguinte forma:

O bloco das termas ocupa uma unidade de actus quadratus do quadriculado. Os seus eixos e compartimentos compõem-se a partir deste. Curiosamente, os únicos compartimentos que não se integram na quadricula actus são a cisterna e o corredor de serviços, que permitiam o acesso ao espaço das fornalhas; mas que, por sua vez, se acomodam e acompanham a direcção da muralha (fig. 95).

A oeste das termas, o forum implanta-se de forma a que o seu espaço central ocupe quatro unidades de actus quadratus, que se organizam de forma linear (fig. 96). Assim, o comprimento total do forum corresponde a 480 pés $(4 \times 120)$ e a largura desse espaço a 120 pés, que é determinada por dois parâmentos simétricos à entrada (cabeceira do forum) (fig. 97). Estando esta área livre', o eixo longitudinal deste "corpo central" seria o eixo do forum, e assim as restantes estruturas que compõe este equipamento situar-se-iam nas unidades de actus

${ }_{9}^{9}$ Com excepção do possivel templo no espaço religioso.
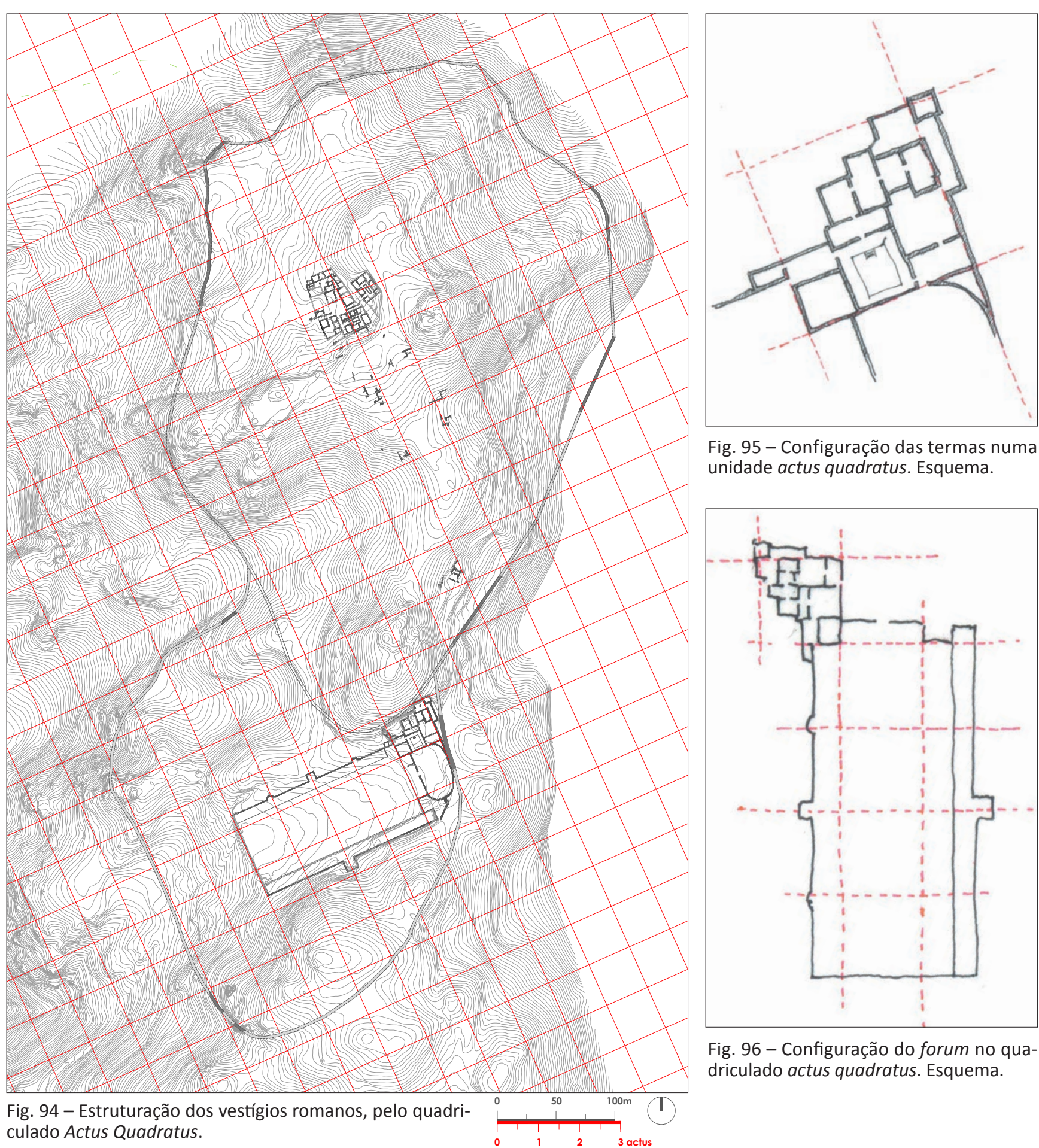

Fig. 95 - Configuração das termas numa unidade actus quadratus. Esquema.

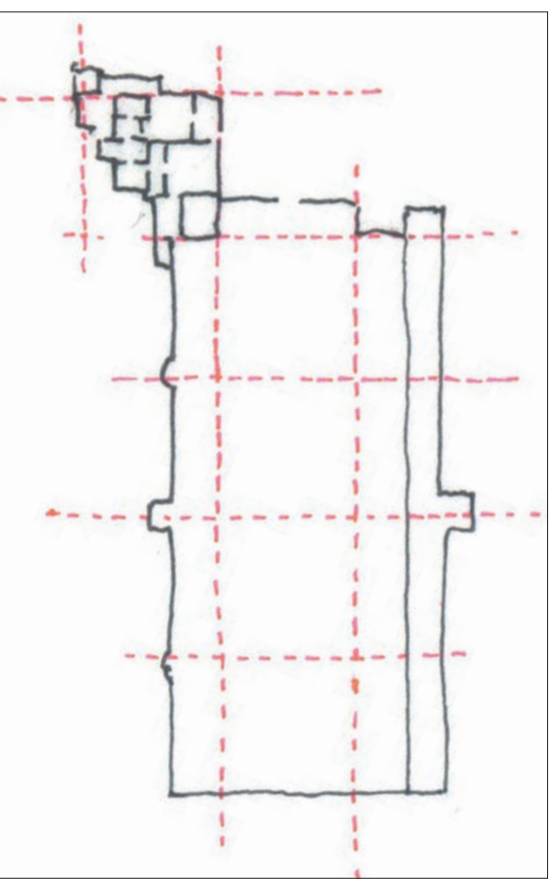

Fig. 96 - Configuração do forum no quadriculado actus quadratus. Esquema.

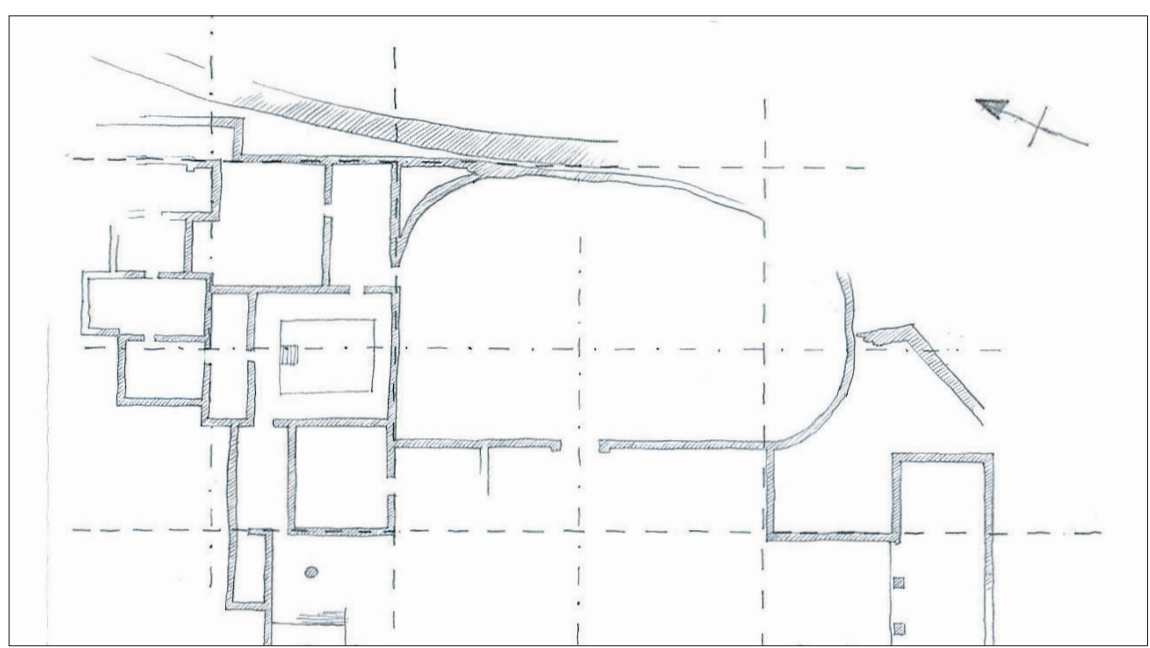

Fig. 97 - Enquadramento das termas e da cabeceira do forum, com respectivos eixos. 
laterais, a norte e sul deste espaço central. Quanto ao eixo transversa do forum, encontrava-se alinhado ao centro das duas absides quadradas e divide o espaço central com duas unidades actus para cada lado ${ }^{10}$ (figs. $98 \mathrm{~A}, 98 \mathrm{~B} \mathrm{e} 98 \mathrm{C}$ ).

Estes dois equipamentos encontravam-se articulados por uma unidade actus onde se posiciona o "espaço oval". Neste espaço cruzam-se os eixos tanto do bloco das termas como do espaço central do forum (figs. 98 D, 98 E e 98 F).

Todo este conjunto de equipamentos (forum, termas, espaço oval) ocupa uma área correspondente a cinco por três actus, um tota de quinze unidades de actus, que tem como eixo de simetria o eixo longitudinal do forum.

Na situação dos vestígios no núcleo habitacional poente, onde se considera a zona de domus como uma potencial insula, verificamos que esta se compõe segundo uma unidade de actus quadractus (fig. 99 A). Mas quando é vista sob a mesma grelha, que se expande a partir do centro cívico, a zona de domus não se enquadra na sua unidade correspondente. Em vez disso, esta aparenta posicionar-se com um desvio de um quarto de actus (seis módulos passus) tanto para sul como para nascente (fig. 99 B).

Uma possivel explicação relaciona-se com a problemática do relevo acentuado em Tongobriga, que terá dificultado uma correct implantação do quadriculado. Como o centro cívico e a zona habitacional se situam em dois pontos distintos, em consequência do relevo, não era possível ter uma relação visual entre um e outro. É possíve que tenha sido implementado um segundo ponto de origem para o alastramento do quadriculado. Desta forma, com dois pontos de origem terá ocorrido um lapso em relacionar uma com a outra, e assim provocado um desvio entre os dois quadriculados ${ }^{1}$

${ }^{10}$ Eixo este que poderá corresponder, segundo Lino Tavares, à passagem do cardo max mos entre o espaço da praça e o espaço do religioso.

Para se obter mais dados acerca deste asssnto te realizar diversos est dos experiências, a partir dos novos dados, em conjunto com os vestígios do núcleo facto se trata de uma os mos dispersos pela alde, de fro sim a perceber-se se quadrículas se teriam encontrado. Perceber se se trataria de uma quadrícula para área habitacional e outra para o centro cívico (sendo estas de fases distintas), ou se se
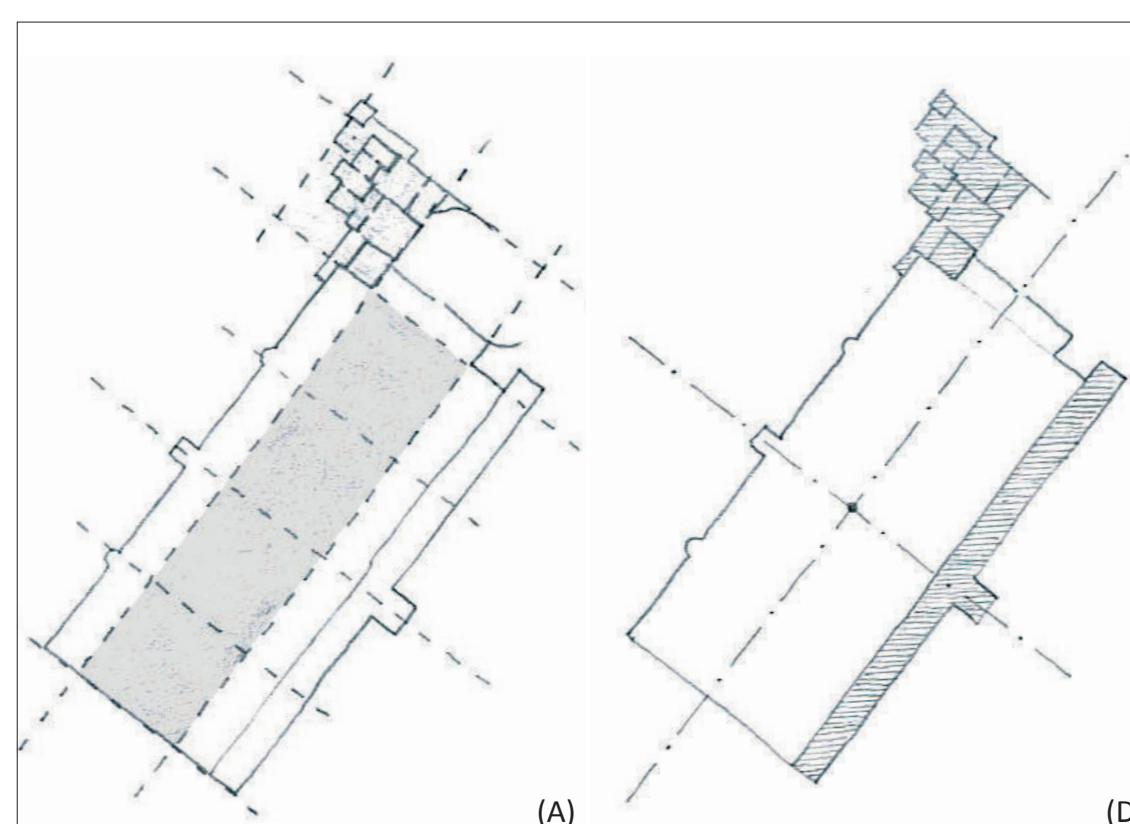

(D)
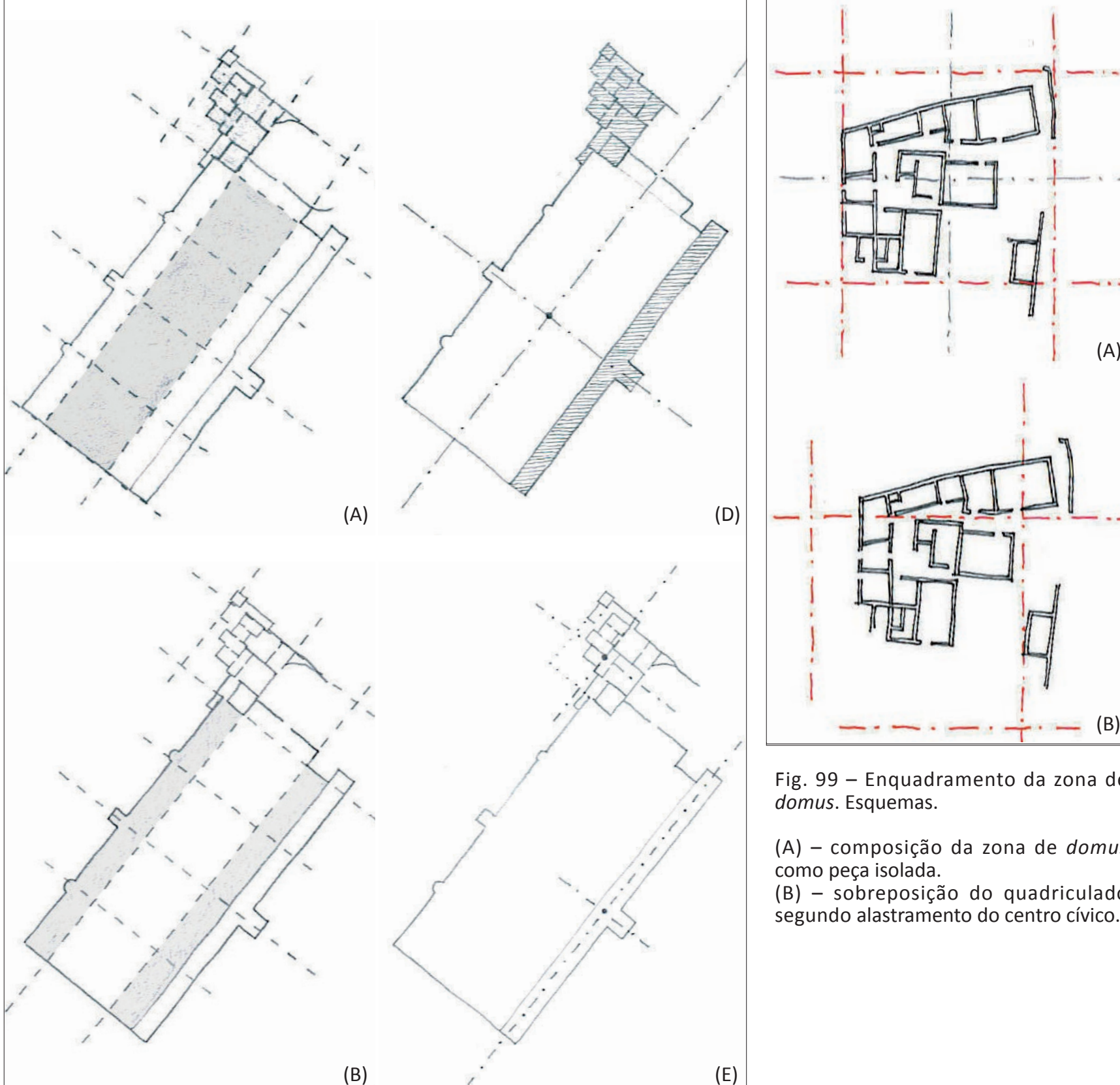

I (A)

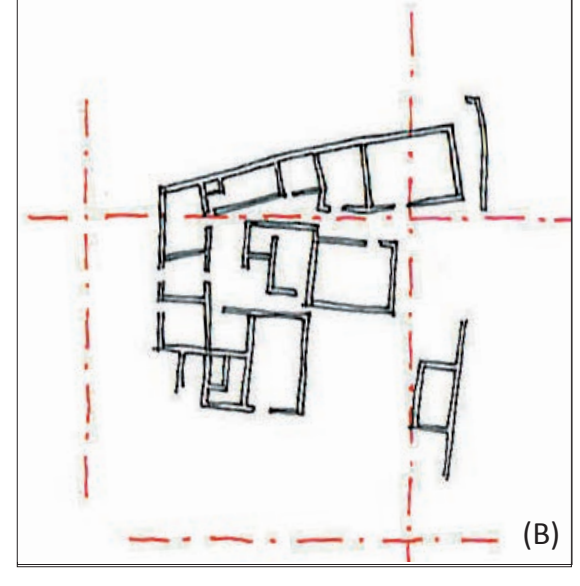

ig. 99 - Enquadramento da zona de domus. Esquemas.

(A) - composição da zona de domus (B) - sobreposiçãão do quadriculado segundo alastramento do centro cívico.

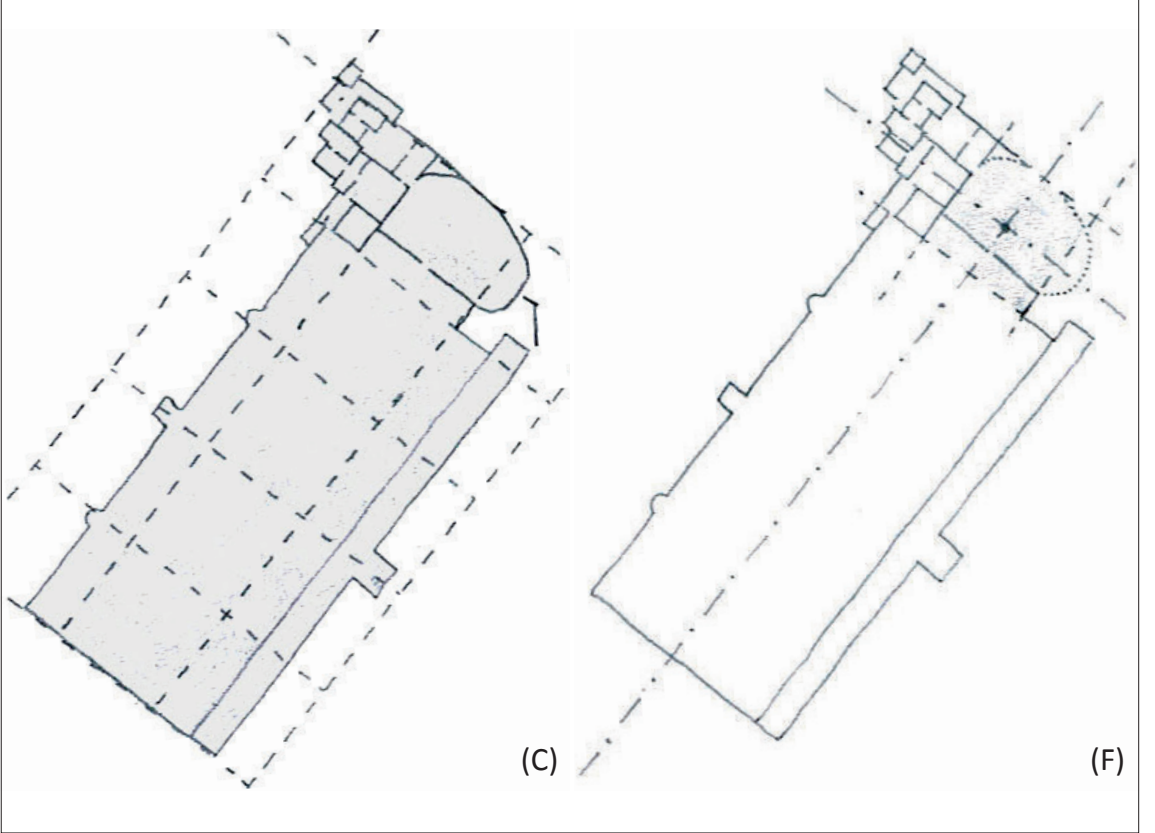

fig. 98 - Organização das estruturas do forum se gundo o quadriculado actus.

(A) - espaço central.
B) - faixas laterais.

(C) - enquadramento do conjunto.

(D) - eixos do forum.

(E) - eixos das termas e plataforma sul.
(F) - articulação de eixos entre termas forum. 
Elementos da situação actual

Quando sobreposto sobre a planta actual da aldeia do Freixo, o quadriculado permite realçar certos elementos. Um deles é uma série de segmentos de rua na aldeia, que se orientam numa direcção norte-sul, e que correspondem aos eixos da grelha proposta. Estes segmentos (cuja a extensão ronda os 240 pés) ligam-se entre si, em ângulos de $40^{\circ}$ ou $45^{\circ}$, estando quase sempre posicionados no próximo eixo, a 120 pés de distância. Estes segmentos podem corresponder, certamente, a primitivos arruamentos (cardos) do tempo romano, que estariam paralelos a um cardo maximos da cidade (figs. 100 e 101).

Numa orientação nascente-poente, manifestam-se dois inícios de rua, coincidentes a eixos da quadrícula. O primeiro é uma estrutura já assinalada como decumanos por sinalização turística, e faz um ângulo de $90^{\circ}$ com um dos cardo (fig. 100 A). O segundo consiste numa passagem livre entre a edificação contemporânea da aldeia, mas que poderá estar relacionada com o alinhamento da rua a norte da zona de domus no núcleo de habitação poente (fig. 100 B)

Outros caminhos, não alinhados pelos eixos da quadrícula podem corresponder a caminhos romanos. Estes "caminhos" configuram-se em forma de ziguezague pela encosta, por forma a se adaptar ao terreno. Apesar de não corresponder a um eixo preciso, a sua orientação é claramente nascente-poente (figs. 102 A, 102 B e 102 C).

No caso da habitação, é também possível que as casas que ladeiam estes segmentos de rua e que correspondem à mesma orientação desta, e por sua vez à da grelha, correspondam a antigas estruturas de habitação romana, que foram reutilizadas como alicerce das casas actuais (figs. $103 \mathrm{e}$ 104).

O mesmo acontece com outros anexos, muros e equipamentos. Exemplo disso é o caso da Igreja de Santa Maria do Freixo, em que as suas fundações foram identificadas como a antiga Basílica Paleocristã da cidade.

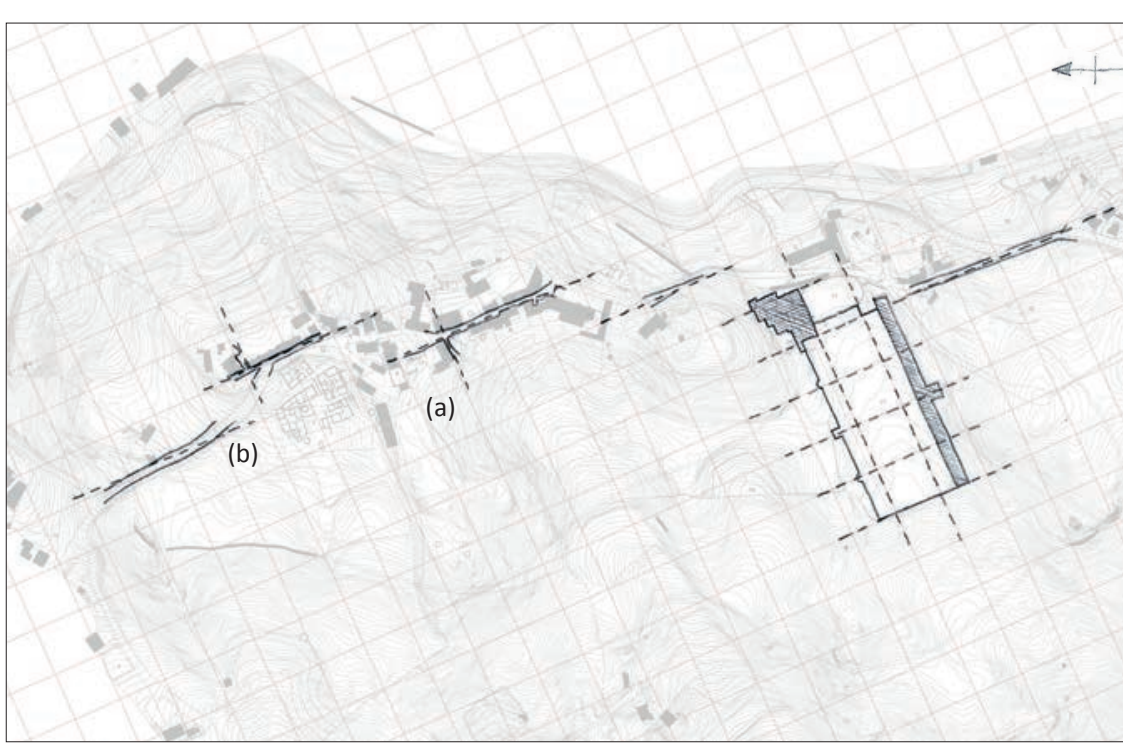

Fig. 100 - Segmentos de ruas correspondentes aos eixos do quadriculado actus.

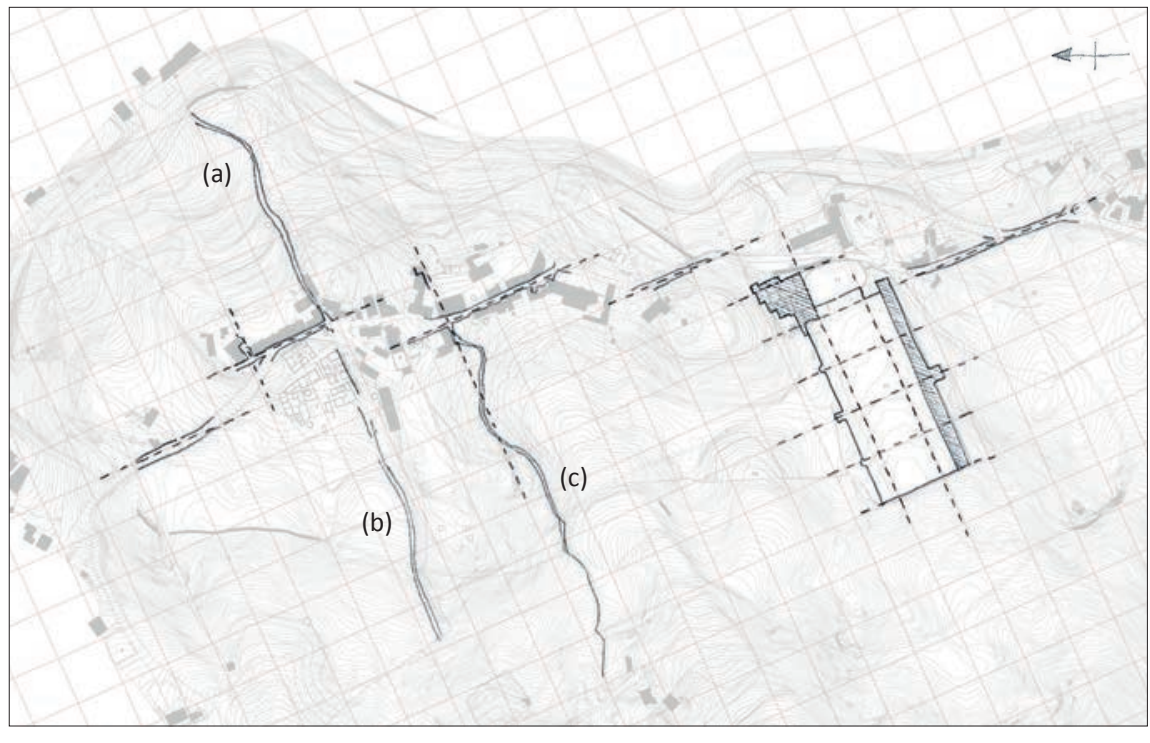

ig. 102 - Segmentos de ruas correspondentes a uma orientação nascente-poente.

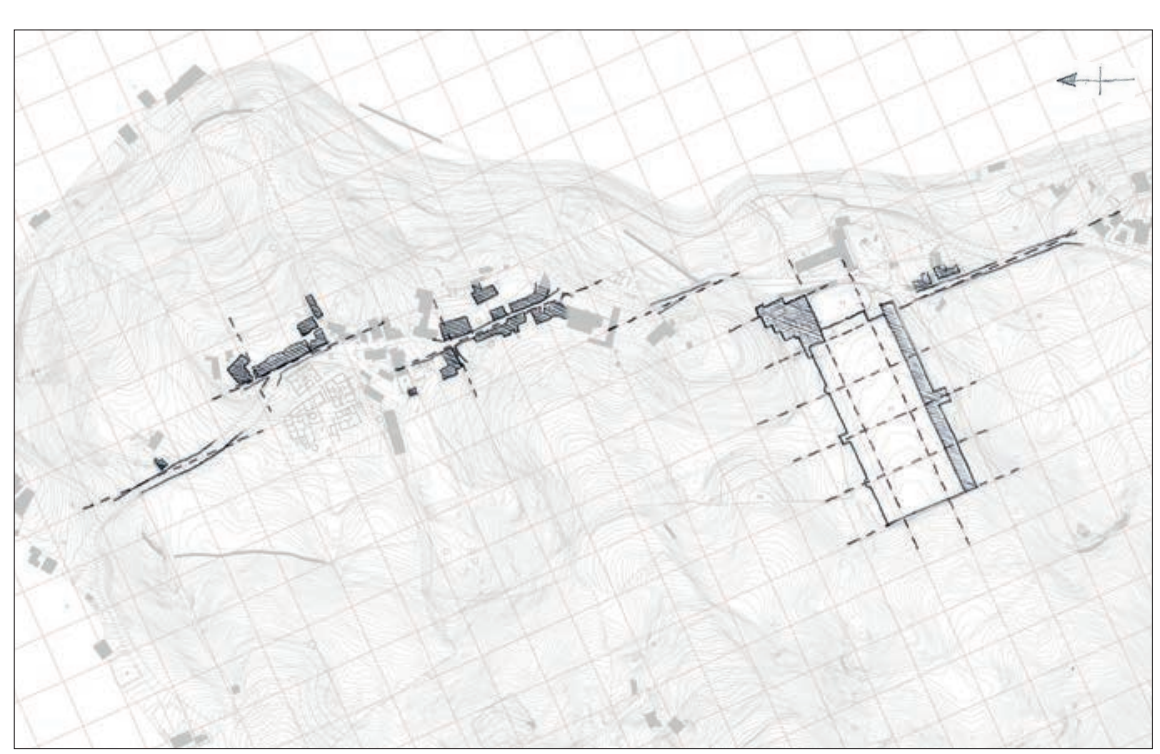

Fig. 103 - Casas que ladeiam as ruas correspondentes aos eixos do quadriculado.

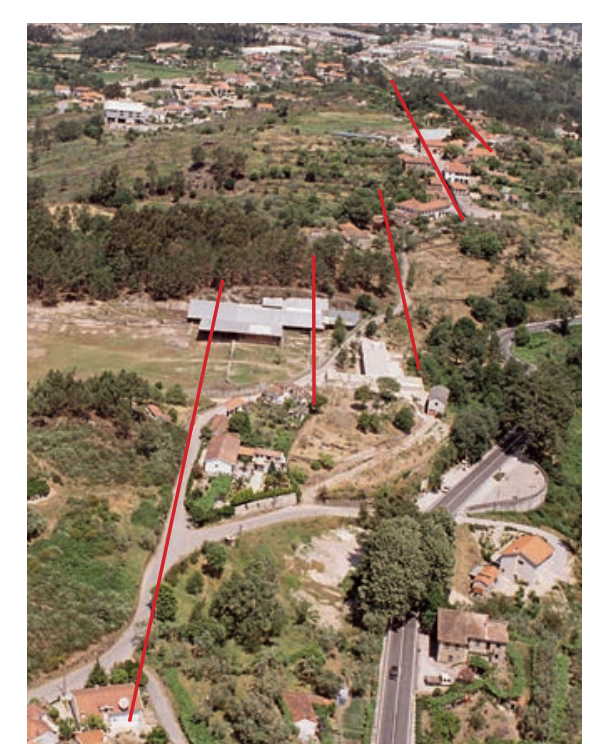

Fig. 101-Realcedas russ na aldeia do Freixo.

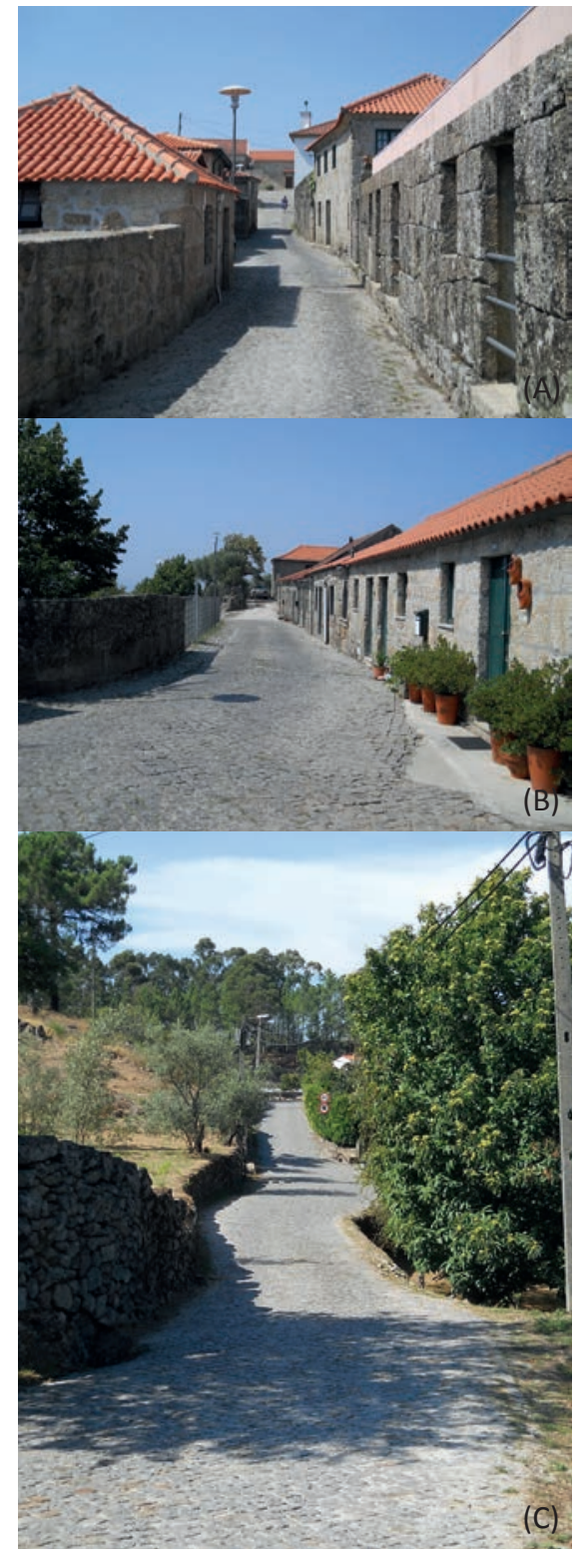

Fig. 104 - Ruas e habitação. Fotografias. 


\subsection{4 - Elementos adaptados}

Quarenta cinco graus

Devido às dificuldades causadas pelo relevo acentuado que se faz sentir em Tongobriga, terá havido certamente ajustes/adaptações do quadriculado à topografia. Tendo em conta os dois casos específicos que se seguem, pensamos que um desses ajustes esteja relacionado com a diagonal do Actus Quadractus.

Na quadrícula do canto nascente do forum (ícone X), é possíve observar a chegada do aqueduto ao espaço oval. Este, embora a sua chegada seja feita de forma ortogonal, um pouco antes, faz uma inflexão que alinha com a diagonal da unidade actus, sendo essa inflexão um desvio de $45^{\circ}$ relativamente à orientação principal. Paralela a este, está a rua actual que dá acesso à aldeia, e que, desta forma, se poderá dizer ter sido uma rua romana (fig. 105).

$\mathrm{Na}$ unidade actus onde se encontram os vestígios do núcleo habitacional nascente (ícone $\mathrm{Y}$ ), verifica-se o mesmo que no exemplo anterior. Para além das ruínas dos paramentos se encontrarem a $45^{\circ}$ relativamente à direcção principal da cidade, também a rua segue a mesma orientação que a diagonal do actus (fig. 106).

A observação destes dois casos permite constatar que o mesmo fenómeno ocorre em diversas situações, um pouco por toda a aldeia. possível reparar que, para além dos segmentos cardo, existe uma série de arruamentos $\mathrm{a} 45^{\circ}$, que correspondem a diagonais de unidades de actus quadratus $^{12}$ (fig. 107)

Segundo este raciocínio, pensamos possível que a posição de ruas nas diagonais dos actus esteja relacionada com a técnica que os agrimensores romanos usavam para a aferição da regularidade da quadrícula.

Sobre esta questão Jean Pierre Adam explica:

"Pode-se pensar que os agrimensores, conhecedores do teorema de Pitágoras, efectuavam periodicamente verificações baseando-se na diagonal, devendo ter esta sempre, para um actus quadratus de 120 pés de lado, um valor muito aproximado aos 170 pés $(169,7)$.

A mesma verificação, aplicada à diagonal de uma centúria devia dar uns 3.400 pés. Garantia-se a estabilidade do sistema (hoje se diria da rede), mediante a medida das diagonais cuja equivalência garantia o quadrado (no caso de uma diferença de valor, o actus qua-

${ }^{12}$ Entre estes, a antiga Rua dos Judeus, da era medieval.

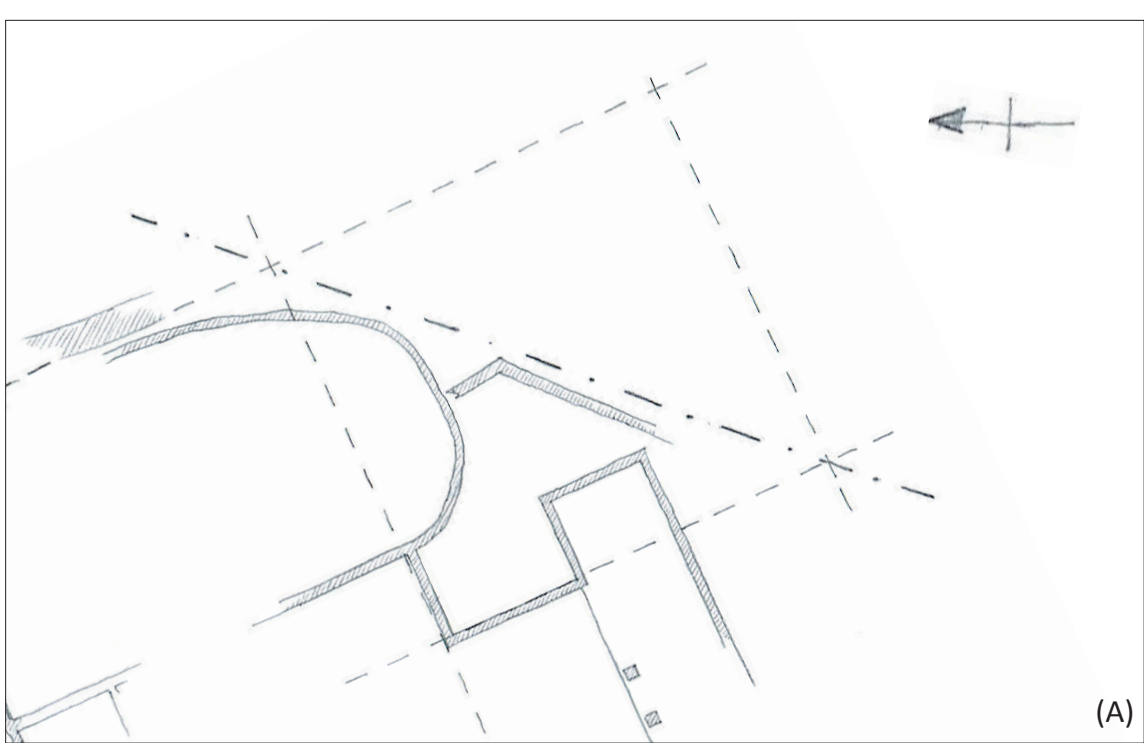

Fig. 105 - Exemplo 1. Quadrícula correspondente ao aqueduto. Planta (A). Vista (B).
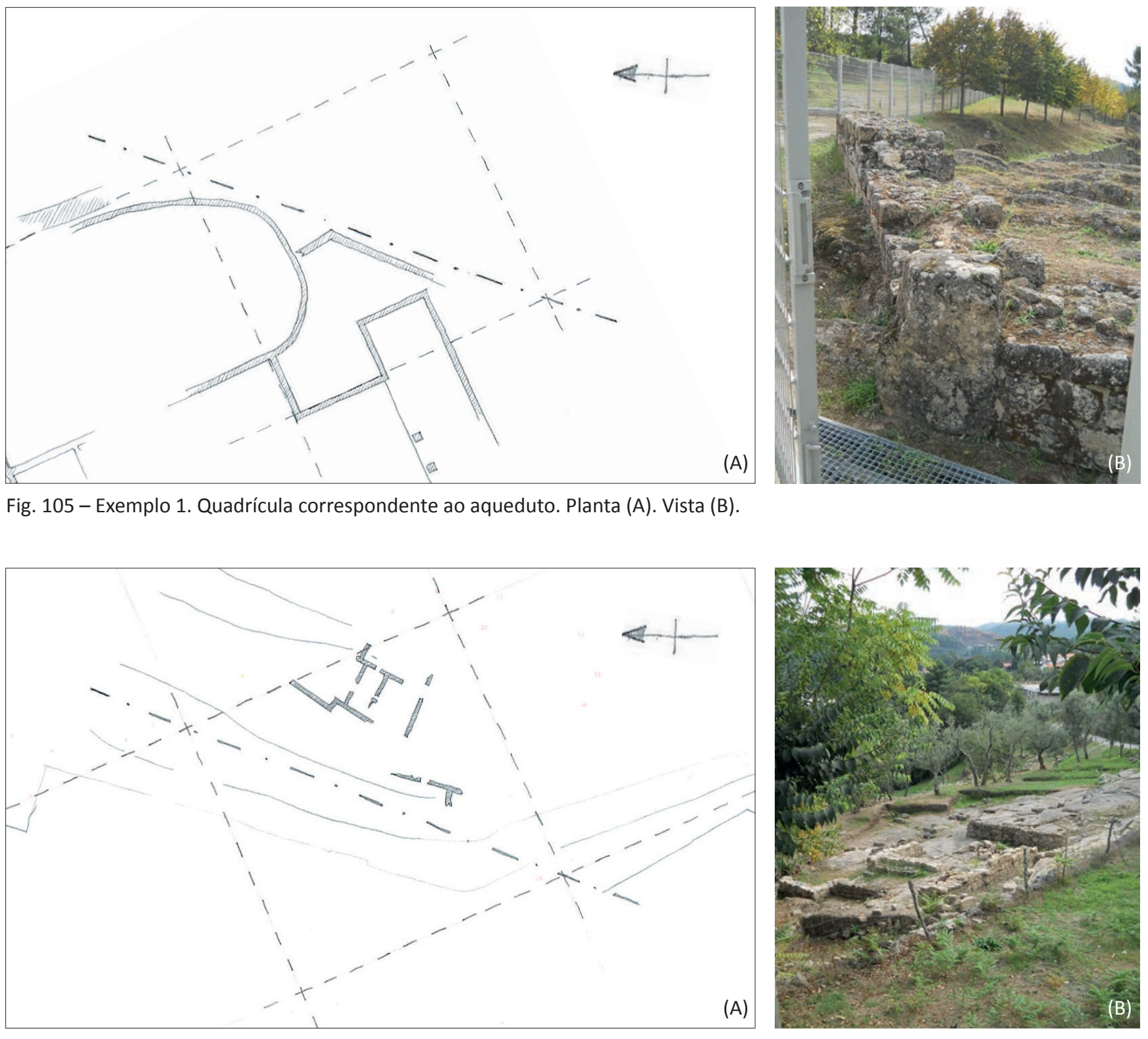

Fig. 106 - Exemplo 2. Quadrícula correspondente aos vestígios da zona habitacional nascente. Planta (A). Vista (B).

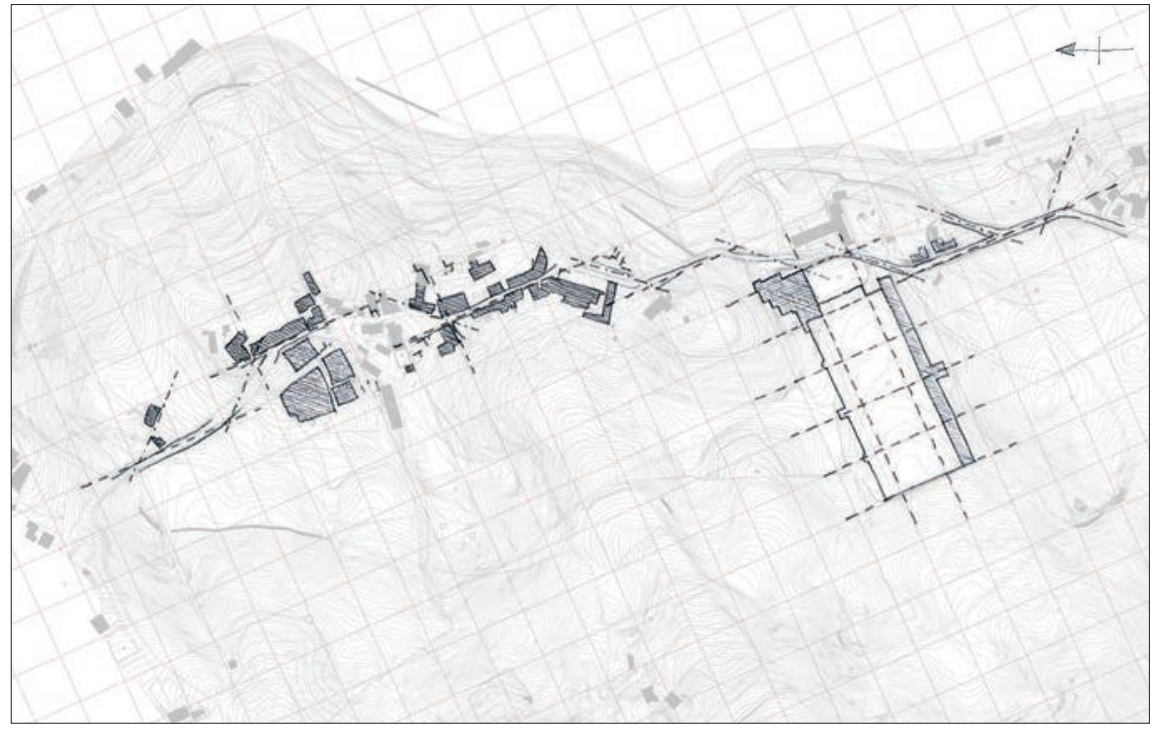

Fig. $107-$ con 10.

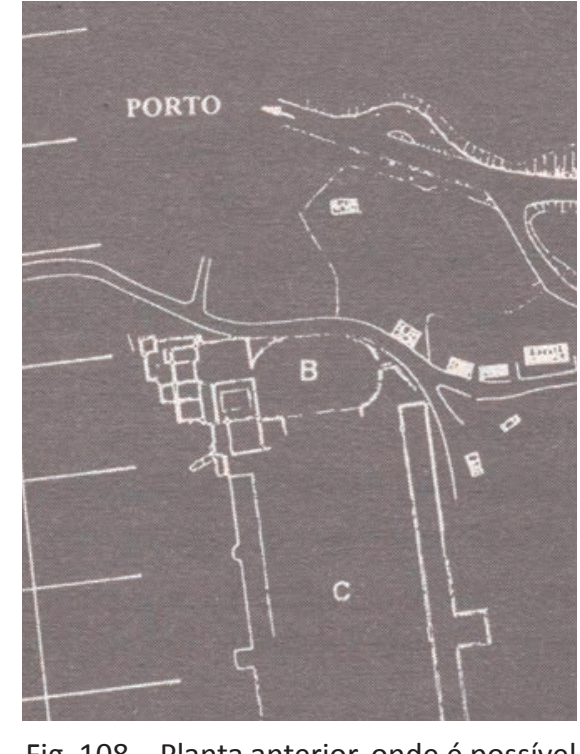

Fig. 108 - Planta anterior, onde é possível ver a posição original da rua antes de ter sido desviada. 
drado ou a centúria pode ser um rombo). É claro que se podia aplicar a mesma operação às superficies rectangulares"13 (fig. 109).

É desta forma que pensamos que, dado o relevo acentuado da cidade de Tongobriga, os romanos, aquando da centuriação destas terras, se tenham apercebido, em alguma situações, que se a rua se situasse na diagonal da unidade actus, esta teria menor pendente, 0 que permitia uma melhor circulação. Daí que as diagonais de aferição tenham servido de orientação a algumas ruas (fig. 110).

Este dado é bastante interessante, pois também se pode associar esse raciocínio a uma rua que, segundo Lino Tavares, faria ligação entre a zona habitacional e o centro cívico. Se considerarmos o ponto de início no decumanos, identificado com uma inflexão de $45^{\circ}$, é possível traçar a hipotética rua até ao espaço do centro cívico, embora não seja possivel perceber a sua chegada a este espaço, nem a sua ligação ao forum, sem uma análise aprofundada ao espaço do teatro ${ }^{14}$ (fig. 110).

Perante a suspeita de um desfasamento entre quadriculados, realizou-se um ensaio, para se perceber como tal situação se teria adaptado ao terreno.

Como as ruínas já exumadas se separam em dois pólos distintos (centro cívico e área habitacional), manteve-se a implantação da primeira quadrícula, com origem no centro cívico, a partir da qual se expande, no sentido das habitações; e implantou-se uma segunda, a partir da zona habitacional poente, que se expande no sentido do centro cívico. Assim, procuram-se correspondências para cada um do quadriculados, por forma a descobrir onde é que se dá o desfasamento, ou então uma zona nebulosa, em que a articulação entre ambas não se torna possível determinar (fig. 111).

O quadriculado que se propaga a partir do centro cívico encontra elementos "sólidos" até ao decumanos assinalado (fig. 111 B). A distância entre este e os vestígios da basílica paleocristã corresponde a um actus. E quando visto o enquadramento das ruínas nesse actus é possível verificar que os vestígios da rua se encontram na metade do actus; daí a posição da quadrícula se confirmar.

${ }^{13}$ Jean Pierre Adam, La Constrution Romaine, 1989, p. 13

${ }^{14}$ Dado o relevo acentuado desta cidade, esta rua principal seria extremamente importante na ligaçao da populaçáo ao forum (praça da cidade). Esta rua, em tempos ou às diagonais na cidade de Barcelona. Arruamentos em que o objectivo é reduzir distância entre dois pontos importantes, evitando-se assim uma circulação em ziguezague ao longo de um quadriculado.

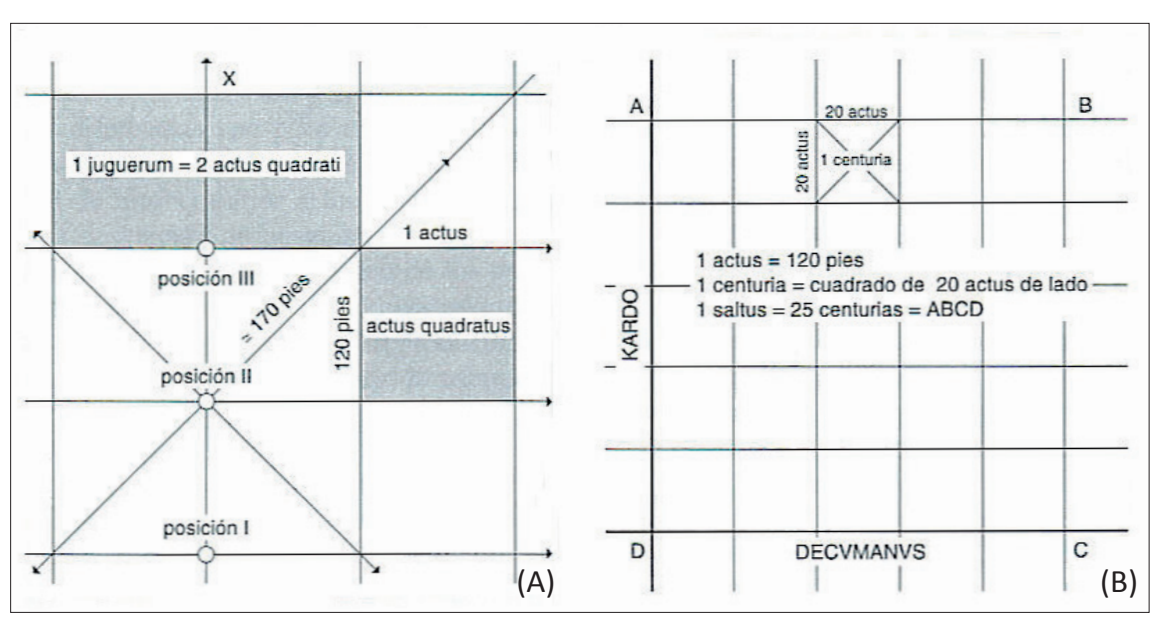

Fig. 109 - Progressão de uma implantação cadastral com o uso do actus e da jugeurum como unidade de longitude e
superfíice (A). Esquema de centuriação
quadrado (B).

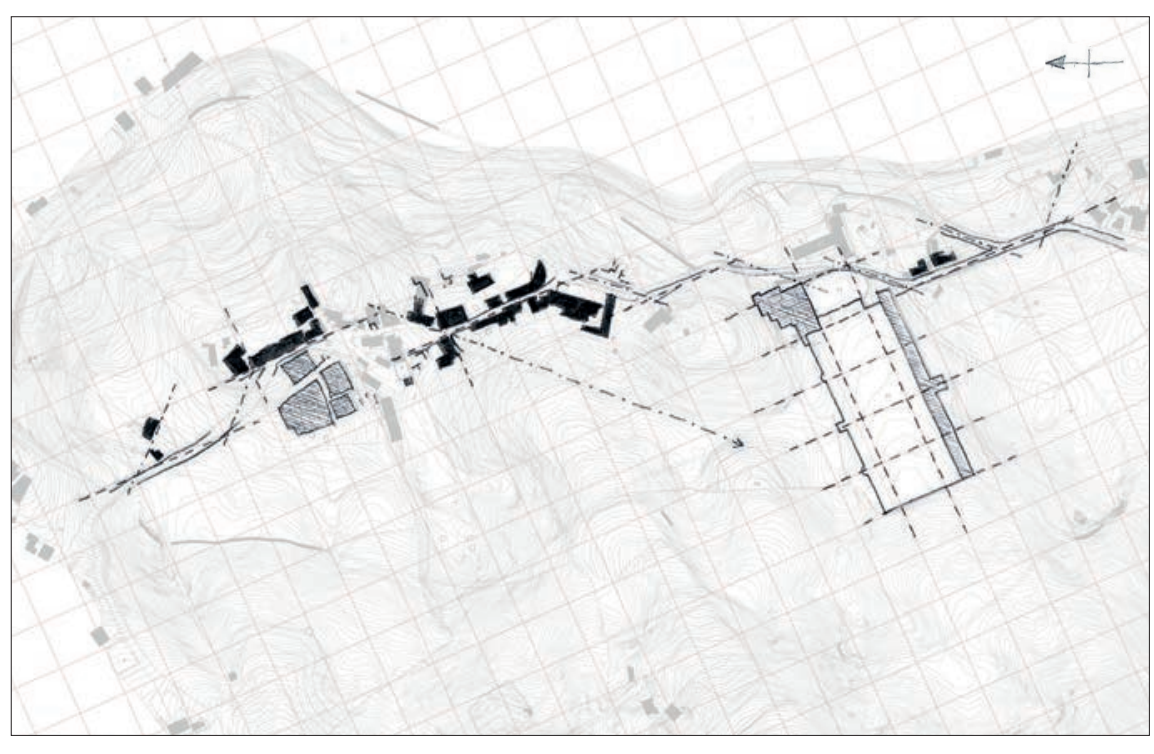

Fig. 110 - Indicação da rua diagonal que
ligaria o centro civico à zona habitacional.

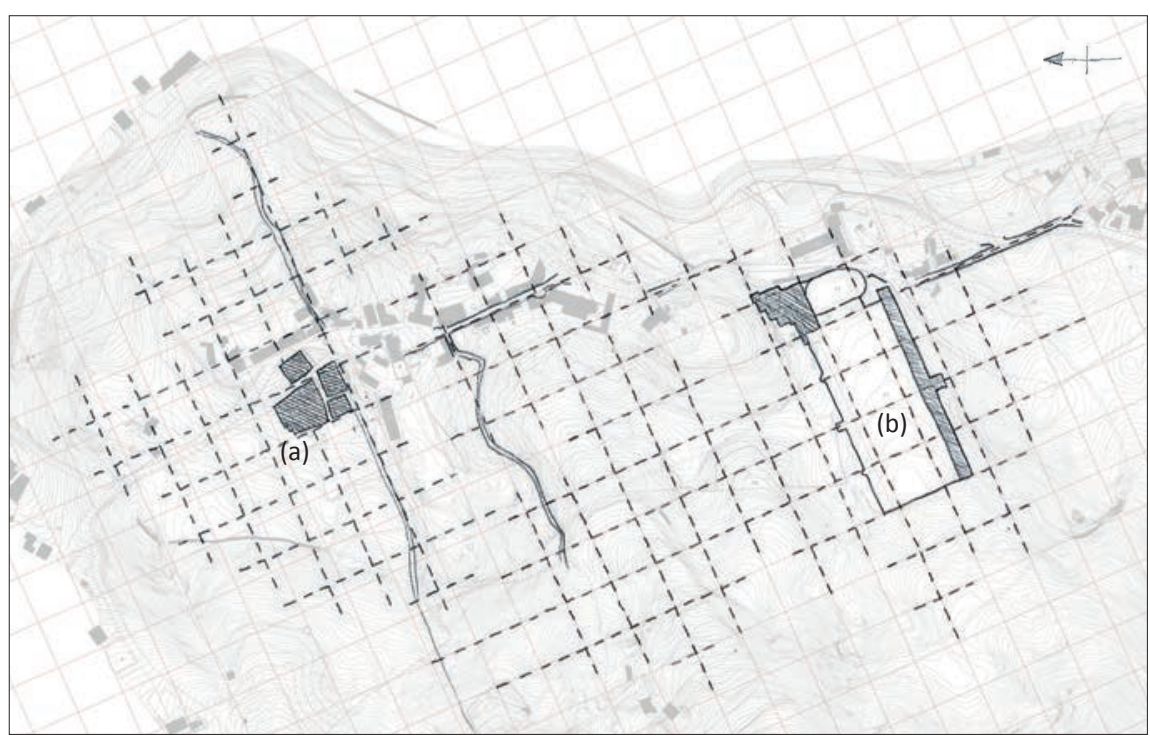
Fig. 111 - Alastramento do quadriculado
actus, com dois pontos de origem. Zona habitacional (a), centro cívico (b)

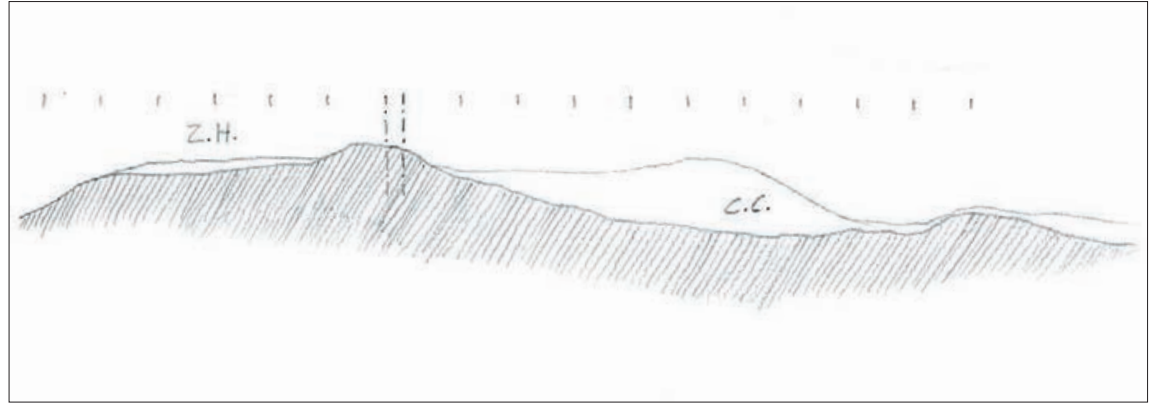

Fig. 112 - Perfil do terreno. llustração da quebra visual entre o centro cívico e a 
Já o quadriculado que se fixa na zona habitacional poente implanta-se de forma a obter correspondências nos vestígios das habitações (fig. 111 A). Com esta implantação, verifica-se também que dois dos caminhos, mencionados atrás, agora correspondem aos eixos do quadriculado (rever fig. 102). O que se torna curioso é que a distância entre a Casa do Impluvium e os vestígios da basílica paleocristã correspondem à largura de um actus (tal como acontece do outro lado).

Este ensaio permite dizer que a cidade de Tongobriga era organizada por duas grelhas desfasadas; o que, por coincidência ou não, provoca uma zona nebulosa, com um quarto de actus (seis passus) no espaço onde se encontram os vestígios da basílica paleocristã (figs. 112, 113 e 114).

Caso este desfasamento tenha sido intencional, não se poderá associá-lo à implantação da basílica, pois tal só ocorre na segund metade do século IV ${ }^{15}$, muito depois da implementação deste quadriculado. Poderá, no entanto, ser credível, se pensarmos que a basílica foi construída sobre uma outra estrutura romana.

Tal situação não é muito difícil de imaginar, pois esta banda nebulosa, como lhe chamamos, corresponde à única zona no espaço da cidade onde é possível relacionar, visualmente, ambas as áreas.

Desta forma, com um reacerto dos elementos detectados até este ponto, é possível ter uma visão organizada da cidade de Tongobriga

Através da sobreposição do quadriculado, podem realçar-se outros elementos como muros de suporte, anexos ou mesmo taludes, que poderão corresponder a vestígios ainda não identificados ${ }^{16}$.

Neste sentido, identificámos uma parcela de terreno cujas dimensões correspondem a um actus; mas a sua posição, embora alinhada por elementos de um e outro sector, não se encontra perfeitamente enquadrada na grelha ${ }^{17}$. Este elemento poderia justificar a posição de um terceiro quadriculado, que articularia as restantes duas; mas para se verificar tal situação, só com futuras sondagens se poderá confirmar se de facto se trata de uma insula romana (figs. 115 e 116).

${ }^{15}$ Ver Tongobriga. Breves Reflexões, Lino Dias, 2003, p. 17.

Năo e de surpreender que estes elementos não sejam exactamente coincidentes com o traçado dos eixos da quadricula, pois como noutras sondagens realizadas, os vestigios de paramentos romanos encontram-se desviados um a dois metros dos elementos actuais. Tal situaç̧ão é bem visivel nos vestigios da muralha, junto ao núcleo comum no reaproveitamento de pedra de estruturas romanas para a construção dos socalcos actuais. Um simples gesto de pegar e amontoar a lado da ruína. ${ }^{17}$ O limite nascente deste encontra-se alinhado com o lado poente do forum, norte da parcela alinha com o limite sul da zona de domus.
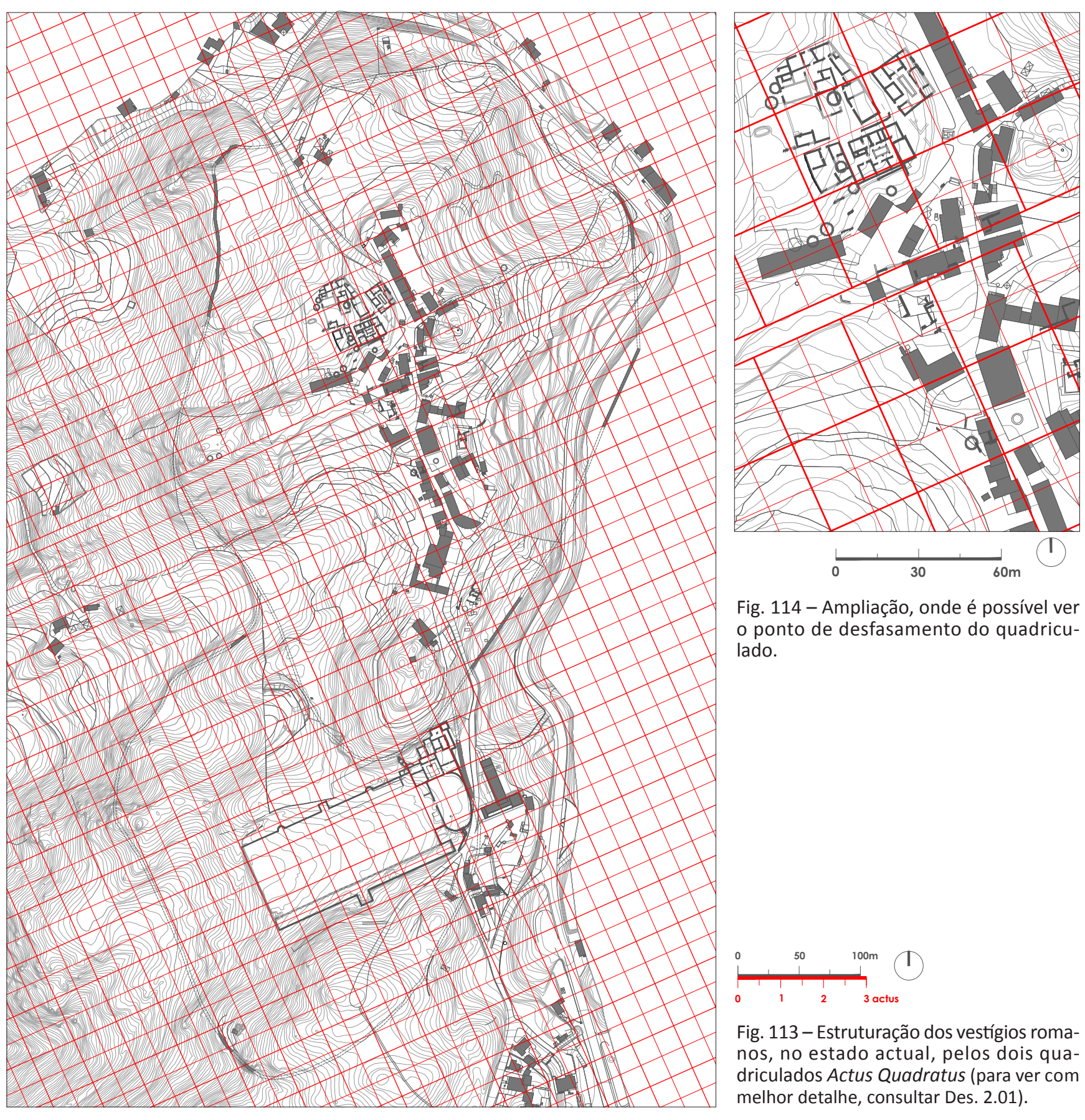

Fig. 114 - Ampliação, onde é possivel ver lado.

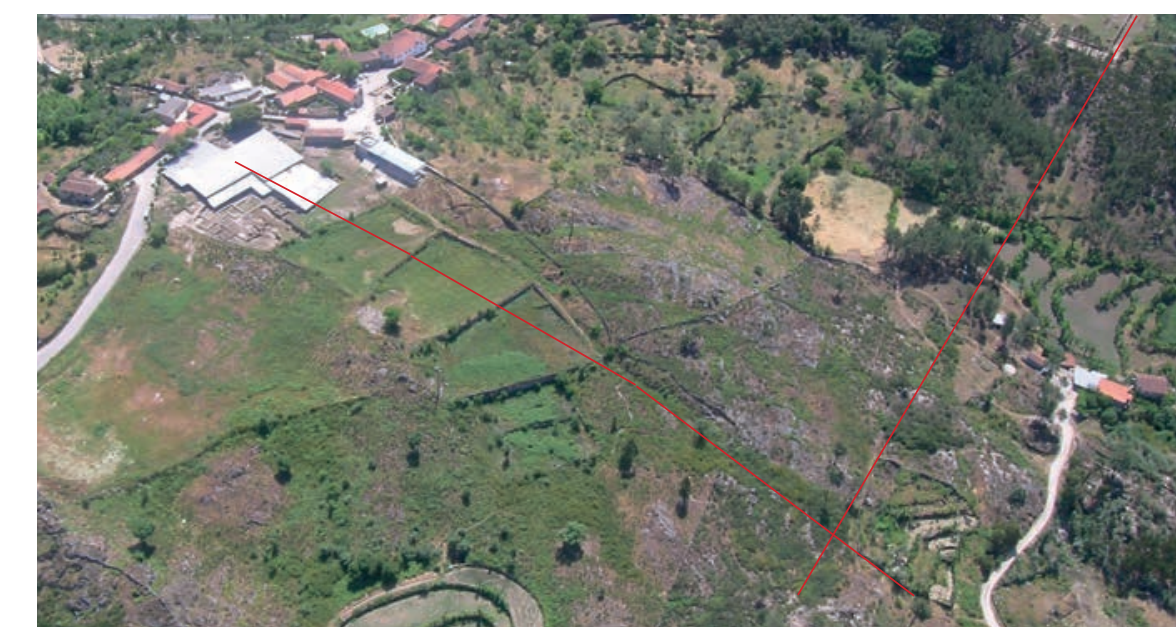

Fig. 115 - Localização da parcela de terreno correspondente a um actus.
Fig. 113 - Estruturação dos vestíigios roma-
nos, no estado actual, pelos dois quadriculados Actus Quadratus (para ver com melhor detalhe, consultar Des. 2.01).

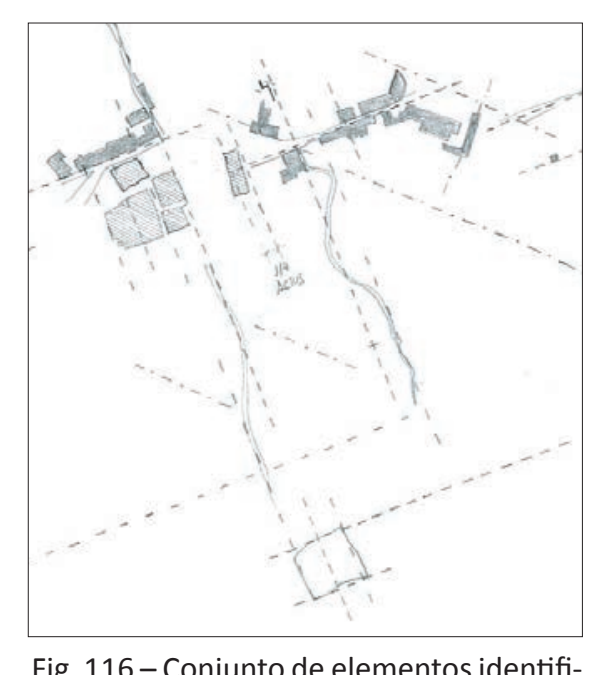
Fig. 116 - Conjunto de elementos identifi-
cados, com a localização da parcela. 


\subsection{5 - Contributo}

Em suma, o conhecimento da aplicação desta métrica vem contribuir para a compreensão global da cidade de Tongobriga. A parti deste dado, é possível imaginar que esta cidade foi construída segundo um projecto preconcebido, onde se procurou respeitar uma grelha de arruamentos de tipo hipodâmico; uma tarefa que demonstra grande determinação pela escolha do lugar, pois o relevo desta área não terá facilitado um traçado ortogonal. Demonstra também que, apesar da cidade se localizar na periferia do império, procurava respeitar da mesma forma os preceitos romanos (regras, unidades de medida, entre outros).

Assim, o conhecimento deste quadriculado ajuda-nos hoje compreender a disposição das estruturas romanas na Área arqueológica do Freixo, ao mesmo tempo que permite estabelecer relações entre as estruturas. Este conhecimento permite o estudo individual de cada equipamento, assim como o estudo da sua posição na cidade (fig. 117).

Este contributo auxilia também na procura de novos vestígios, em que o quadriculado serve de guia (matriz, descodificador, decifrador), o que transmite maior certeza à procura. Permite estabelecer prioridade a hipóteses e a zonas de maior interesse de exploração.

Neste sentido, este dado permitiu a análise que se segue das estruturas do centro cívico, assim como o apoio à sua reconstituição.

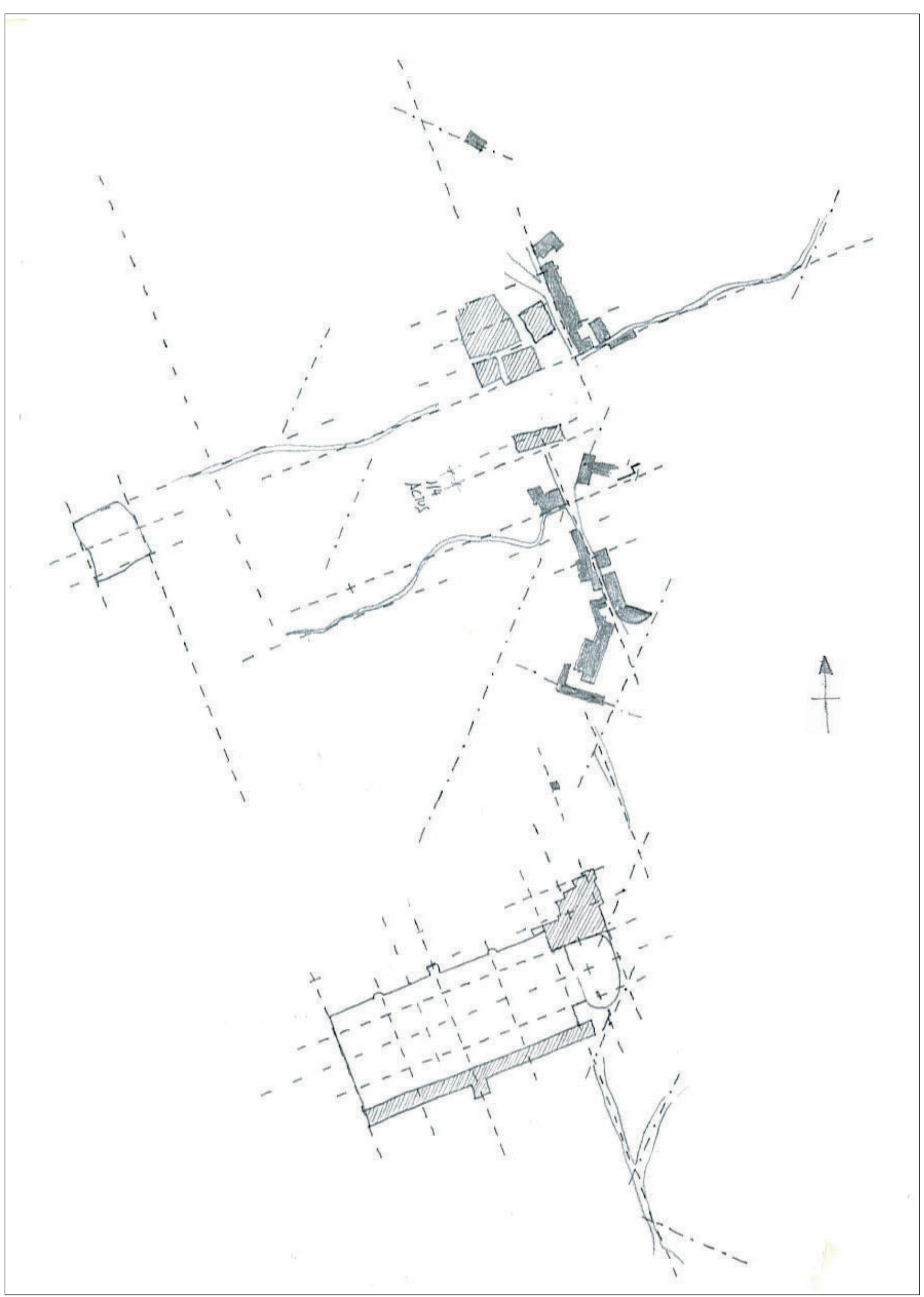

Fig. 117 - Resumo dos elementos identificados através do uso do quadriculado Actus Quadractus, após descoberta do desfasamento. 


\section{0 \\ 2.2 - Forum romano}

Inicialmente, o estudo do forum tinha como objectivo a procura de pistas para ajudar a chegar a um traçado do teatro de Tongobriga. $\mathrm{O}$ estudo do forum e a interpretação dos novos dados poderiam ajudar a entender a posição e o desenho do teatro, tanto no enquadramento urbano como no enquadramento do próprio centro cívico. No entanto, o seu estudo começou a revelar dados interessantes para se explorar no seu próprio desenho.

Dada por conhecida a composição do forum, expressa anteriormente ${ }^{1}$, procurou-se entendê-lo neste momento em conjunto com os novos indícios que têm surgido em recentes sondagens; e tendo estes vestígios visto a luz do dia em diferentes ocasiões, agora aqui reunidos torna-se possível lançar novas hipóteses em torno de como terá sido o desenho deste grande espaço público.

\subsection{1 - Vestígios}

Até ao início desta investigação, algumas sondagens encontraram dois grupos de cavidades no afloramento granítico, a que se atribuiu a função de sapata de colunas. Um primeiro grupo, composto por cinco na área norte do forum (fig. $118 \mathrm{~A}$ ), e um segundo, composto por três, junto à plataforma sul2 (fig. 118 B).

Do primeiro grupo, três das cavidades foram encontradas sensivelmente a meio do espaço, anteriormente conhecido como rua. $O$ eixo é composto pelas cavidades e é paralelo ao muro norte, distanciando-se deste $3.5 \mathrm{~m}$. As cavidades distanciam-se entre si cerca de $7,35 \mathrm{~m}$. O eixo composto pelas outras duas encontra-se a $4.90 \mathrm{~m}$ deste e situa-se por cima de uma sucessão de valas no afloramento (valas semelhantes às referidas anteriormente ${ }^{3}$ no canto nordeste do forum . Este segundo eixo alinha na longitudinal com as valas identificadas no topo nascente do forum, e alinha na transversal com o primeiro conjunto de três sapatas (fig. 119).

Existe tambem, ao fundo da "rua", junto à entrada para as termas, uma cavidade escavada no afloramento que se assemelha em dimensão e alinhamento com as sapatas encontradas (figs. $118 \mathrm{C}$ e 121).

O segundo grupo de cavidades é composto por três sapatas similares às encontradas do lado norte (fig. 120). Estas sapatas possuem

Ver capítulo Áreas Públicas. Forum, pp. 64-67.

metro de varia entre $1 \mathrm{~m}$ e $1.1 \mathrm{~m}$ Ver capítulo Áreas Públicas. Forum, pp. 64-67.

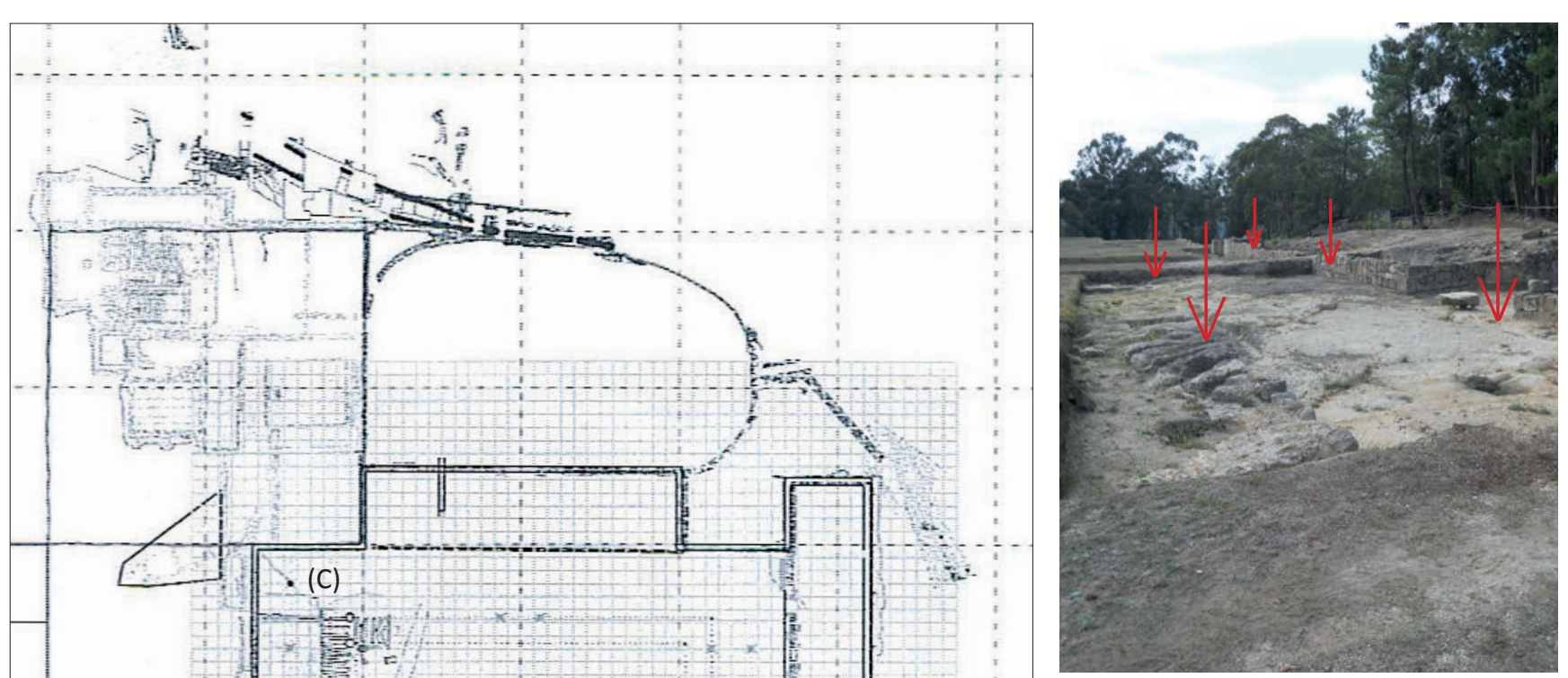

Fig. 119 - Grupo de sapatas junto ao muro Fig. 119-Grupo de
norte (fig. 118 A)

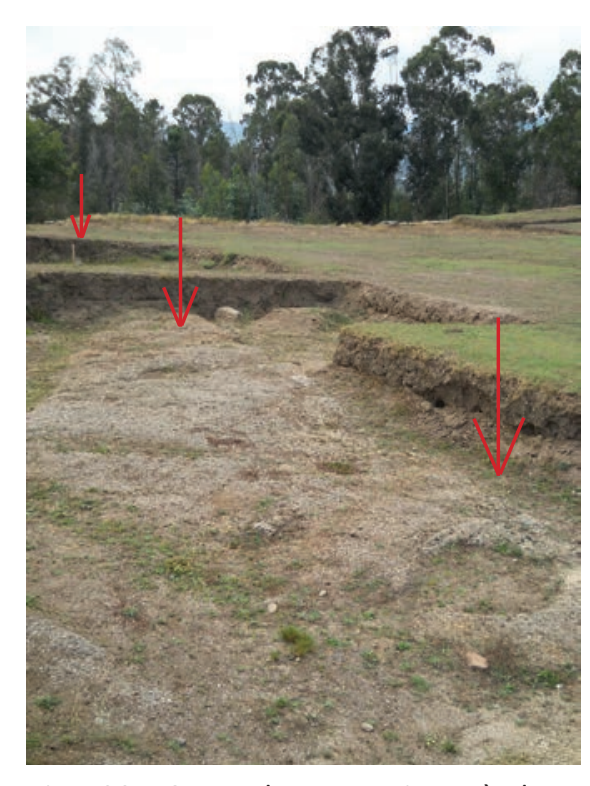

Fig. 120 - Grupo de sapatas junto à plataforma comercial sul (fig. 118 B).

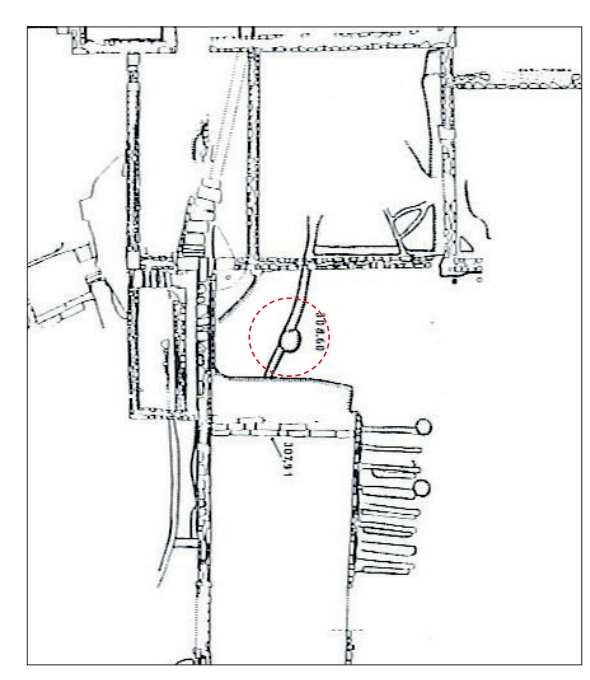

Fig. 121 - Sapata junto à entrada das

ig. 118 - Esboço realizado em visitas ao forum com

ESC. $1 / 1000$

dentificaç 
o mesmo diâmetro e o mesmo distanciamento, quer em relação à plataforma quer entre elas; e alinham na transversal com as encontradas no grupo norte.

\subsection{2 - Pórticos norte / sul}

A primeira interpretação que se faz a partir destes vestígios está relacionada com a disposição dos pórticos no forum. Se pegarmos no conjunto das cinco sapatas no lado norte do forum e no conjunto de três junto ao edifício comercial, a sul, e estendermos estes alinhamentos longitudinalmente, com a mesma métrica de distanciamento existente entre eles, obtemos três linhas de colunas. Por uma questão de composição simétrica, como a colunata da plataforma regista um intercolúnio distinto dos restantes três, podemos assumir que se deve pôr de parte a ideia da plataforma sul como pórtico integrante no forum; e considerarmos este como um edifício adjacente. Desta forma aparentemente, se pode afirmar que está em falta uma segunda colunata do lado sul do forum (fig. 122).

Em favor desta interpretação temos, de origem arqueológica, os vestígios dos talhes paralelos no afloramento granítico, e que aparecem pontualmente em alguns pontos do forum ${ }^{4}$ (figs. 124, 125 e 126). Ao verificar a implantação deste sistema, denota-se que os seus limites deixam livres duas faixas laterais, onde se julga ter existido um duplo porticado de cada lado.

Outro dado a favor desta teoria é a própria grelha actus quadractus. Quando esta se vê sobreposta ao forum, existe uma área central que é delimitada com 120 pés de largura por 480 pés de comprimento (4x120); área esta que corresponderá ao espaço drenado, e que contempla o espaço da praça e o espaço religioso. Deixa assim de cada lado um corredor com oito passus de largura (um terço de actus). Isto

${ }^{4}$ Em Março de 2011 foram realizadas sondagens que colocaram a descoberto mais áreas com talhes paralelos. A diferença em relacão às sondans anteriores foi que foram descobertas não só na envolvente do espaço do forum, como também numa área mais central (fig. 123).
Em função dessas recentes sondagens, é possivel dizer que estes talhes fazem parte de um sistema de escoamento de águas que abrange toda a plataforma do forum. Aqui foram encontrados, em certas zonas, para alem dos talhes no granito, a recriação dos mesmos em saibro. Portanto, em teoria, toda a plataforma tem um sistema de talhes recortados sempre que possivel no afloramento, e, quando não possível tal e, sobre estes, o pavimento. Este sistema permitiu criar um nivel freático em a a diferença de material permite o fácil escoamento das águas na direcção dos tal hes (muito semelhante ao sistema actual de gravilha e tubo drenante). Ainda hoje este sistema mantém a plataforma livre de águas.
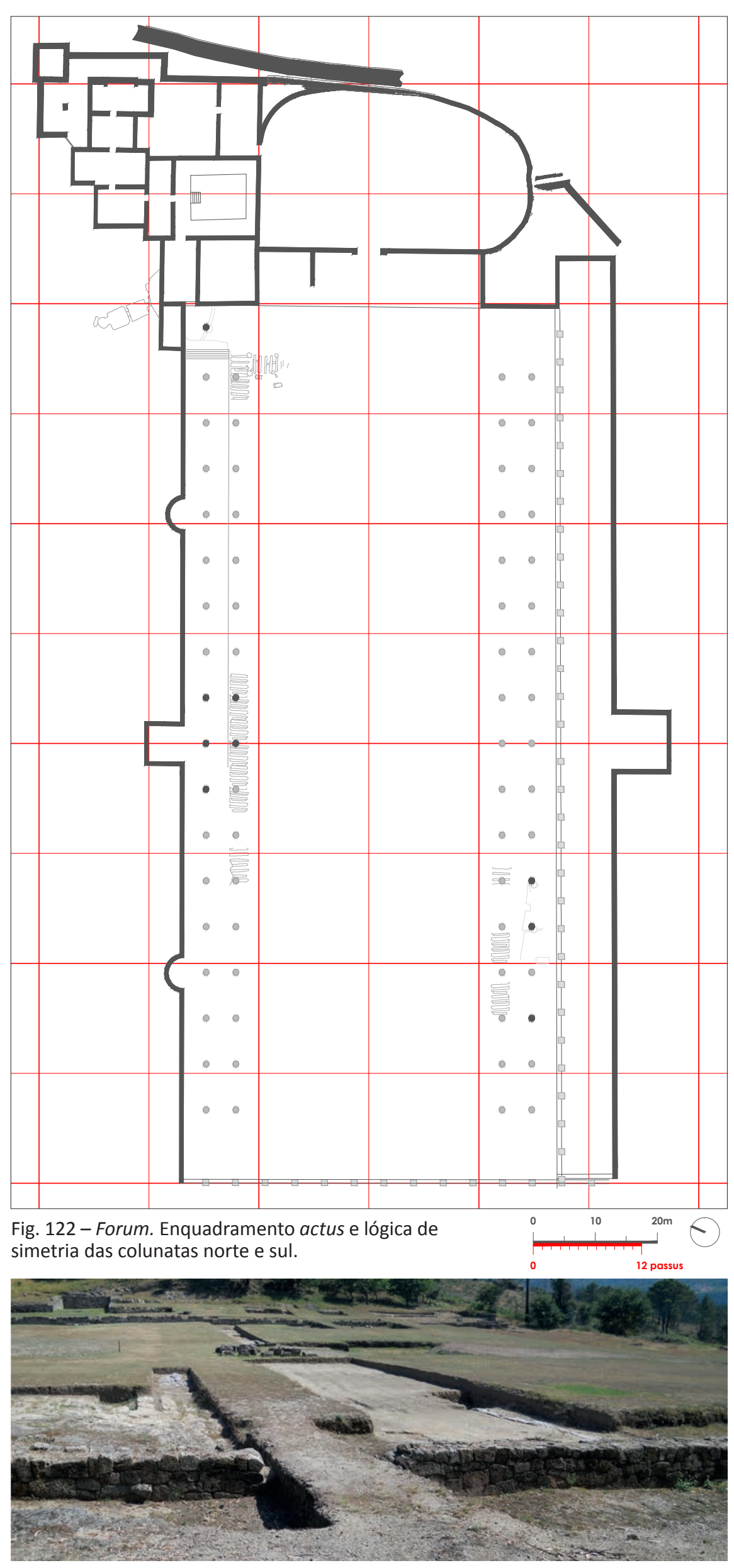

Fig. 123 - Área escavada onde é possivel ver a função dos talhes.

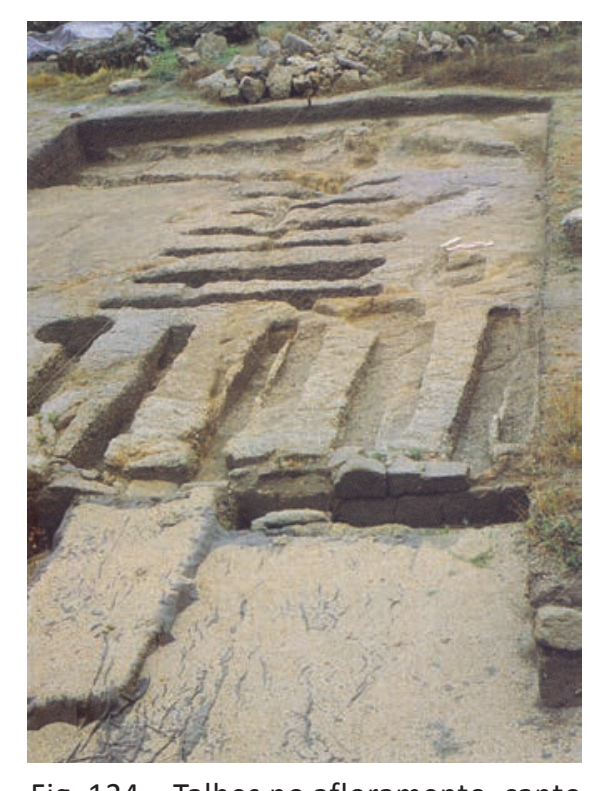

Fig. 124 - Talhes no afloramento, canto ordeste do forum

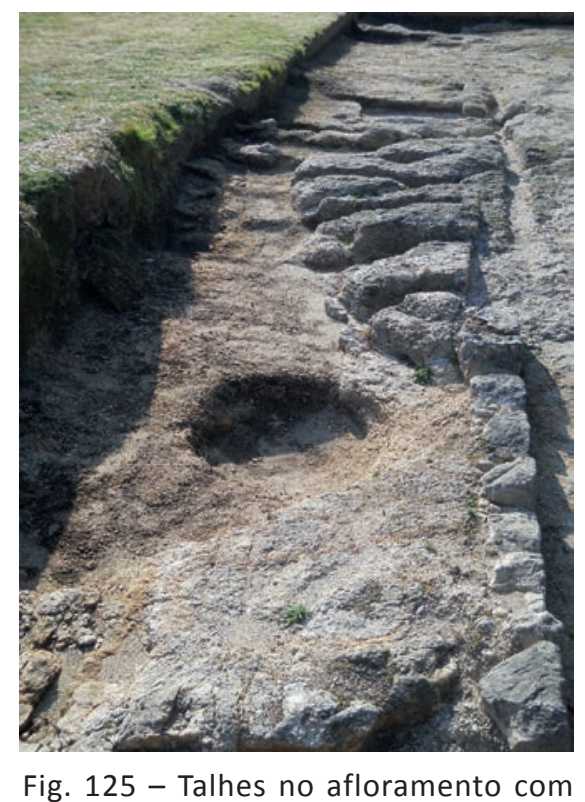

Fig. 125 - Talhes no afloramento com
sapata, junto ao muro norte do forum.

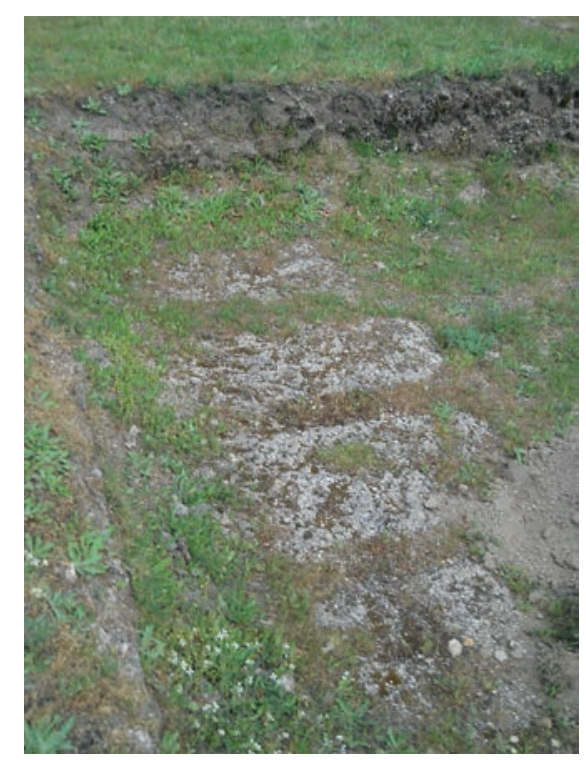

Fig. 126 - Talhes no afloramento, pertencente ao grupo de sapatas sul. 
parece demonstrar, numa lógica de projecto e de desenho, que este forum estaria ladeado pelos pórticos referidos.

No decorrer do ano 2011 foram realizadas sondagens pela equipa da Estação Arqueológica do Freixo, nas quais se confirmaram sapatas do primeiro alinhamento de colunas, tanto a norte como a sul do forum (figs. 127 e 128). De igual modo se confirmaram a presença dos talhes no afloramento, que validam o enquadramento proposto (fig. 129). Mas do segundo alinhamento no porticado sul apenas a nuance de uma sapata foi encontrada até agora.

A diferença, no espaçamento, registada entre o intercolúnio dos pórticos do forum e o intercolúnio do pórtico da plataforma comercial torna pouco credível que estas estruturas tenham coexistido; levantando uma questão: terá o forum de Tongobriga assistido a diferentes fases de construção?

Do ponto de vista do arquitecto, a composição simultânea destes intercolúnios no forum seria compreensível, se a plataforma comercial tivesse pertencido a uma fase distinta, talvez anterior, em que o espaço do forum teria servido apenas como espaço aberto destinado a trocas comerciais. Desta forma, o planeador encarregue do desenho do forum teria optado por um intercolúnio diferente aquando da sua reformulação.

Mas, segundo referência de Lino Dias, percebe-se que estes dois intercolúnios não teriam coexistido; pois a nível estratigráfico verificou-se que as sapatas estavam cobertas por um pavimento de saibro endurecido, o que inverte o raciocínio anterior. Tal leva a crer que, numa primeira fase, tínhamos o forum com os seus pórticos corres pondentes, e só depois, numa fase posterior, se terá construído a plataforma comercial; ao mesmo tempo que se terão feito remodelações no forum (retirada de pórticos e nova pavimentação)

Segundo dados arqueológicos, referidos por Lino Dias, a primeira fase do forum terá correspondido a um período posterior, a "Claudio-Nero", e a segunda fase ao período "Trajano-Adriano".

De acordo com estes novos dados, decidimos prosseguir com a investigação, centrando-nos na reconstituição da primeira fase do forum, ainda antes da referida construção da plataforma. Neste sentido, pretendíamos considerar que o muro sul do forum teria uma composição simétrica de absides, no muro norte; mas, segundo referência de Lino Dias, não existem evidências de estas alguma vez terem existido. Assim, consideramos este muro com um limite recto.

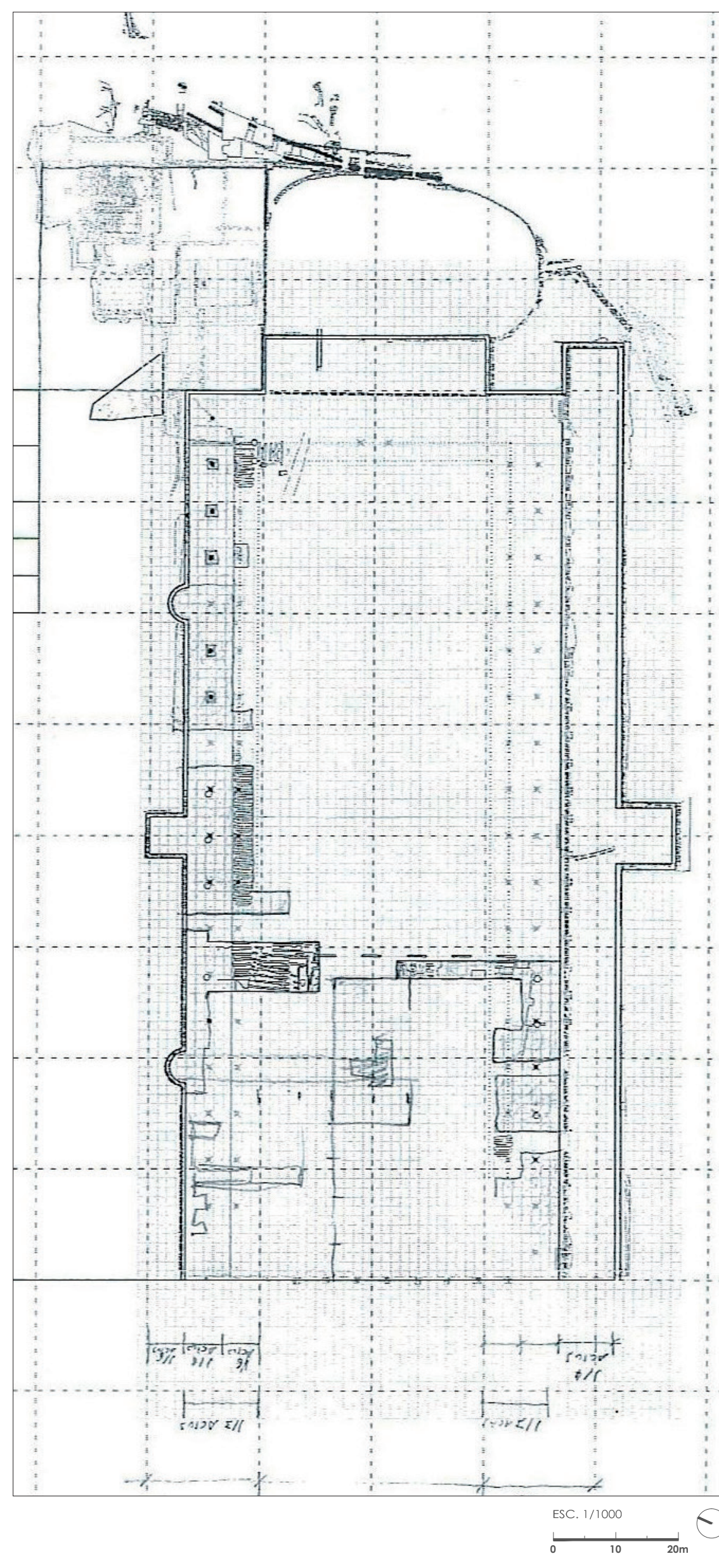

Fig. 127 - Esboço realizad
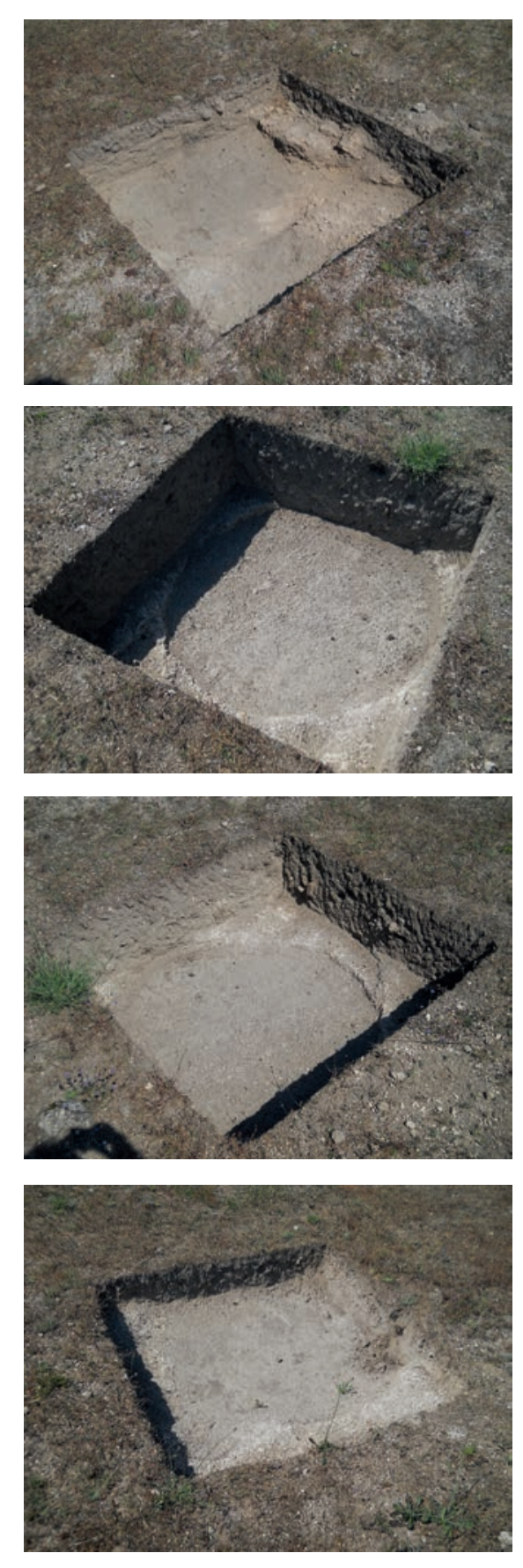

Fig. 128 - Sapatas de colunas. Recente sondagem.

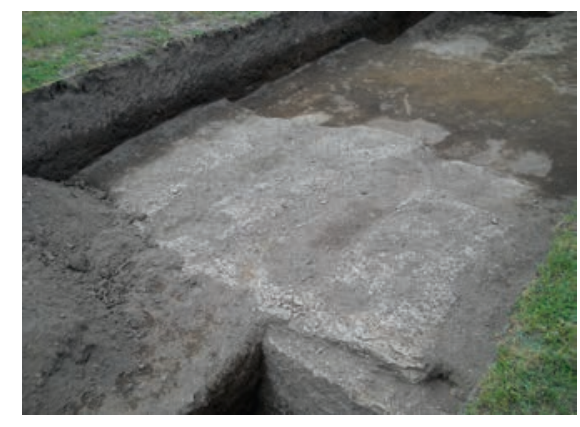

Fig. 129 - Talhes no afloramento. Recente sondagem. 

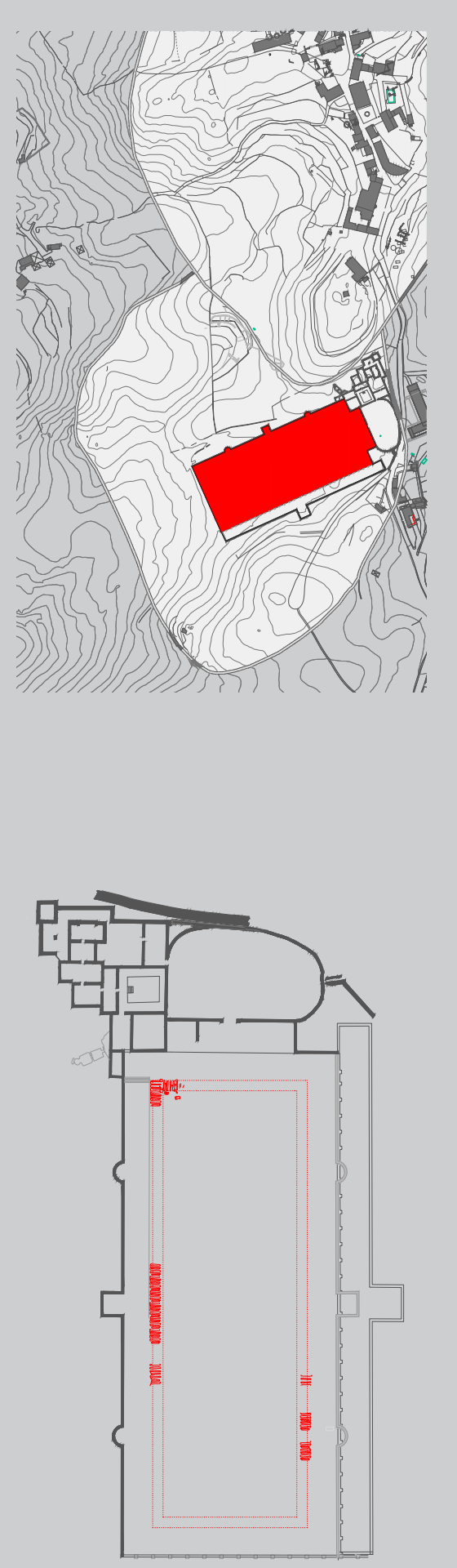

Fig. 130 - Esquema de delineamento dos talhes no espaço do forum.
A sua inexistência poderá estar relacionada com o afloramento rochoso que ali existe; afloramento esse que levou também à construção da plataforma numa cota mais elevada.

\subsection{3 - Pórticos nascente / poente}

Prosseguindo com a investigação, ao observar a posição do talhes ${ }^{5}$ no forum, é possível imaginar o seu delineamento neste espaço (fig. 130). Repara-se no canto nordeste, onde os talhes efectuam uma viragem alinhada pelos degraus junto às termas (figs. 132 e 133). Aí, se imaginarmos uma linha de $45^{\circ}$, obtemos um alinhamento que corresponde com uma cavidade no afloramento e o canto do forum. Assim, obtemos um eixo que simetriza a viragem das colunas. Se imaginarmos a extensão deste talhe em todo o forum, obtemos um espaço de $7 \mathrm{~m}$ de largura, tanto a nascente como a poente.

Dada esta reflexão, retoma-se a possibilidade de terem existido porticados nestes dois espaços ${ }^{6}$. Estes ajudariam certamente no controlo e enclausuramento do espaço do forum.

Desta forma propõem-se os pórticos neste espaço, em que se mantêm as métricas e as distâncias usadas nos pórticos laterais (fig. 131).

Ss talhes que se têm mencionado até aqui são cravados no afloramento granítico por forma a criar um padrão em que a parte escavada tem um pé de largura e o espaço 6 " (. I a possibilidade det

riam o forum dos lados terem existido porticados com 7 metros de largura que fechasuficiente evidência arqueológica", Lino Dias, "A Urbanizaç̃o do Nordeste peninsular: O Caso de Tongobriga", op cit, 1999, p. 88.
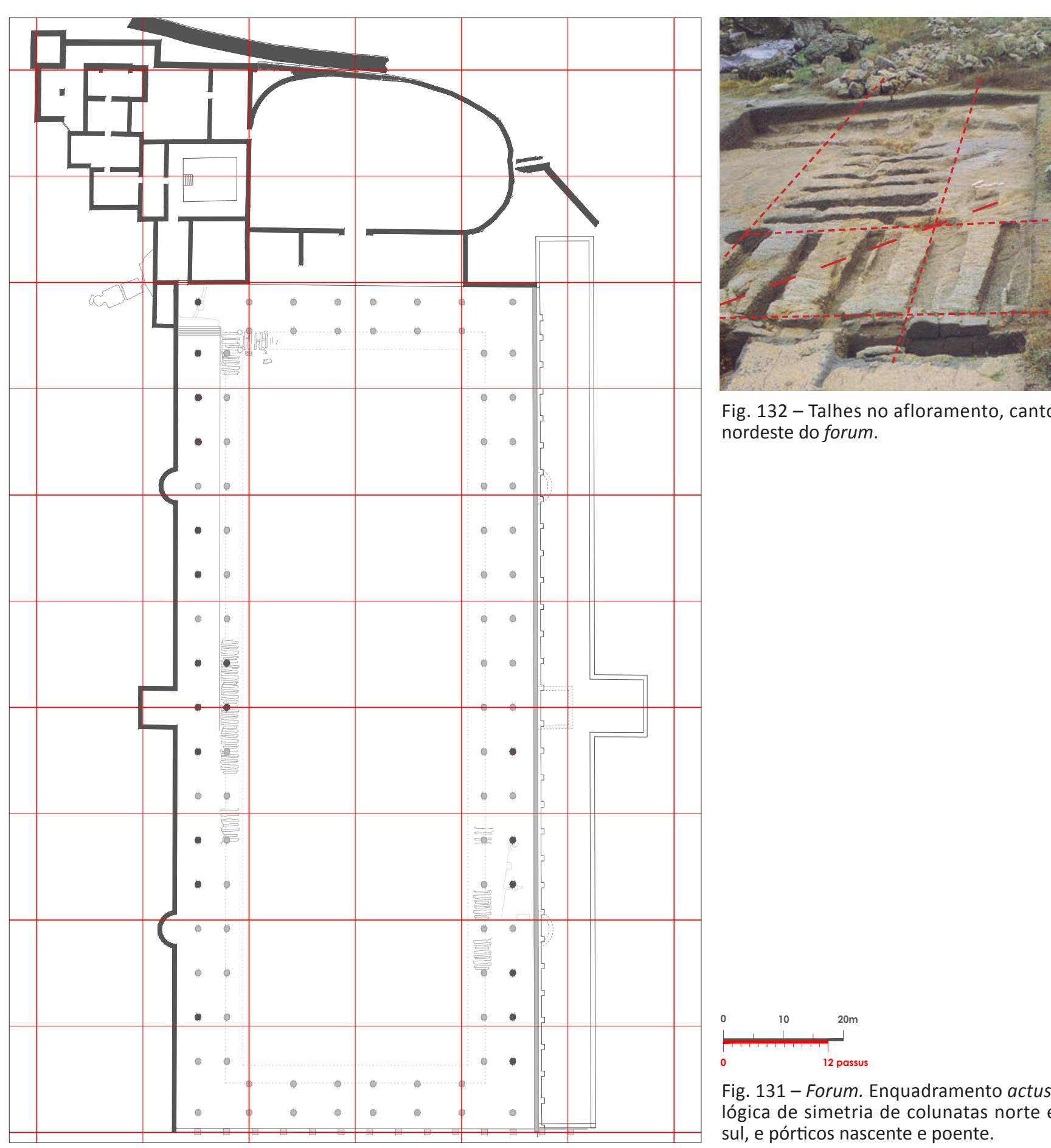

Fis 132 - Talhes no afloramento, canto nordeste do forum.

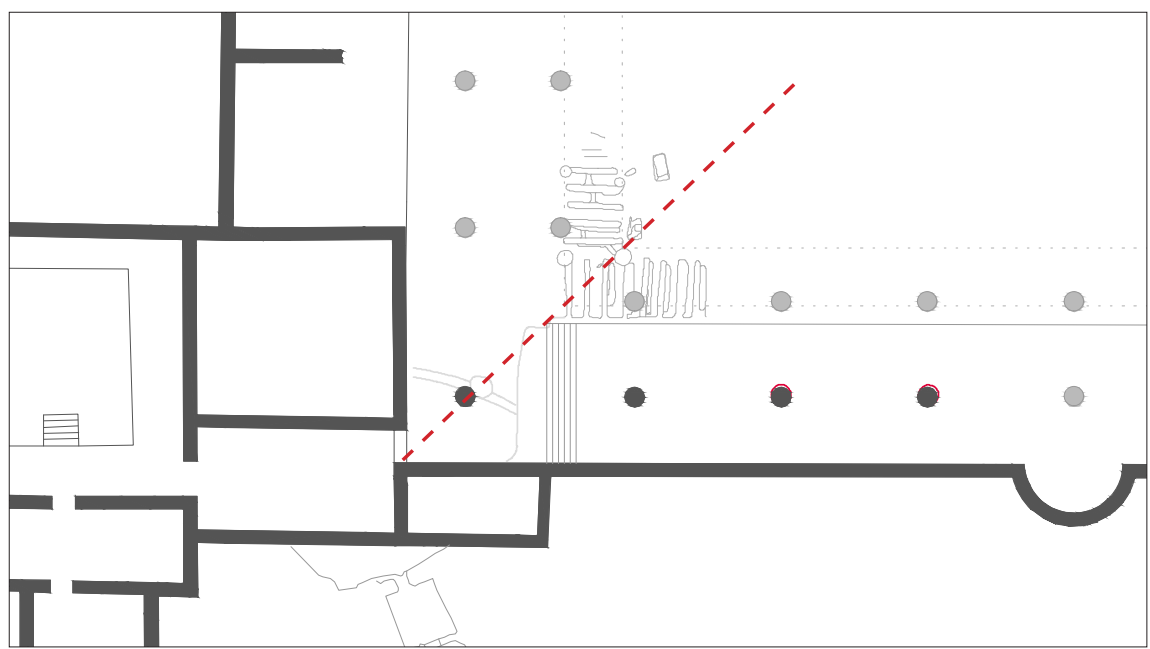

ESC. 1/500 L

Fig. 133 - Aplicação do ângulo de $45^{\circ}$ no canto nordeste do forum. 


\subsection{4-Métricas e proporções romanas}

Em determinada fase desta investigação, questionámo-nos at que ponto faria sentido prosseguir com a análise do forum em metros; medida que pertence a um sistema métrico que não existia no tempo romano; e, por esse motivo, achamos pertinente compreender o sistema métrico, e proporcional, do período romano.

A arquitectura consta, segundo Vitrúvio ${ }^{7}$, de: ordenação ${ }^{8}$, disposição ${ }^{9}$, euritmia ${ }^{10}$, comensurabilidade, decoro ${ }^{11}$ e distribuição ${ }^{12}$. Cad uma destas componentes com a sua particular importância para o desenho da obra, e onde nenhuma delas sobrevive sem a outra.

Quando procuramos entender a composição de um edifício romano, as suas métricas e relações proporcionais, estamos a fala essencialmente de comensurabilidade.

Vitrúvio define comensurabilidade como o: "... conveniente equilibrio dos membros da própria obra e na correspondência de uma determinada parte, entre as partes separadas, com a harmonia do conjunto da figura. Assim como no corpo humano existe a natureza simétrica da euritmia a partir do côvado, do pé, do palmo e de outras pequenas partes, o mesmo acontece no completo acabamento das obras. Em primeiro lugar nos templos sagrados, seja pelas espessura das colunas, seja pelo tríglifos ou mesmo pelo embater; na balista, pela abertura a que se diz dipechyaia; igualmente a partir das partes de outras obras se descobre uma lógica de simetrias" ${ }^{\prime \prime 3}$.

Compreendemos, assim, que a comensurabilidade permite relação da parte com o todo. Entendemos também que a correcta proporção dessa relação tem como modelo matriz o corpo humano.

Os romanos estudaram de forma exaustiva as proporções do corpo humano, e estabeleceram relações proporcionais de cada membro com o todo. Consideraram-no de tal forma bem proporcionado que quiseram estabelecer o mesmo princípio nos edifícios que construíram:

"(...) se a natureza compôs o homem de modo a que os membros correspondam proporcionalmente à figura global, parece que foi

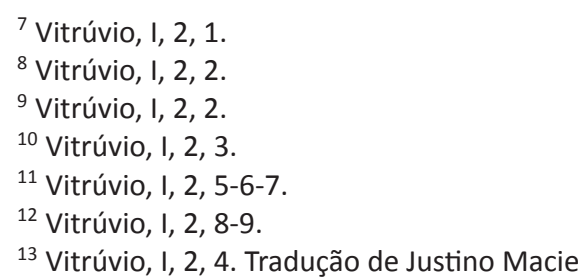

por causa disso que os Antigos estabeleceram que também nos acabamentos das obras houvesse a perfeita execução de medidas na correspondência de cada um dos membros com o aspecto geral da estrutura"14.

Da mesma forma, retiraram do corpo humano as medidas base que constituíram o seu sistema métrico.

"E também retiraram dos membros do corpo humano o sistema de medidas que parece necessário em todas as obras, como o dedo (digitus), o palmo (palmus), o pé (pes), o côvado (cubitus), que dividiram com relação a um número perfeito, que os Gregos dizem teleon (... $)^{\prime \prime 15}$.

Assim, tanto o actus como o passus como o pé, termos aplicados até aqui, são unidades que faziam parte do sistema métrico usado pelos romanos. Um sistema métrico que se geria pelos membros do corpo humano (fig. 134).

Submódulos

A partir da interpretação, da sobreposição da métrica do actus e passus sobre o forum, é possível determinar certas proporções/unidades que se podem relacionar com o desenho deste equipamento. A partir deste estudo, é possível interpretar certos ritmos/métricas que podem fornecer pistas para o seu desenho.

\begin{tabular}{|c|c|c|c|c|}
\hline ACTUS & PASSUS & PES & DIGITUS & METROS \\
\hline 1 & 24 & 120 & 1920 & $+/-35,50$ \\
\hline $2 / 3$ & 16 & 80 & 1280 & $+/-23,66$ \\
\hline $1 / 2$ & 12 & 60 & 960 & $+/-17,75$ \\
\hline $1 / 3$ & 8 & 40 & 640 & $+/-11,83$ \\
\hline $1 / 4$ & 6 & 30 & 480 & $+/-8,87$ \\
\hline $1 / 6$ & 4 & 20 & 320 & $+/-5,92$ \\
\hline $1 / 8$ & 3 & 15 & 240 & $+/-4,44$ \\
\hline $1 / 12$ & 2 & 10 & 160 & $+/-2,96$ \\
\hline $1 / 24$ & 1 & 5 & 80 & $+/-1,479$ \\
\hline
\end{tabular}

Um meio de actus

Esta medida encontra-se em várias ocasiões, um pouco por toda a aldeia (exemplo: largura da casa do Impluvium, casa do poço). A medida, de um meio de actus, verifica-se no eixo longitudinal do forum, pois este divide o espaço central, com a largura de 120 pés (um actus), em duas metades. Na faixa "livre" do lado norte do forum, a medida de um meio de actus revela-se quando incluímos a profundidade da abside quadrada com a largura da faixa. A mesma medida

${ }^{14}$ Vitrúvio, III, 1, 4. Traducão de Justino Maciel. ${ }^{15}$ Vitrúvio, Ill 1,5.5 Tradução de Justino Maciel.

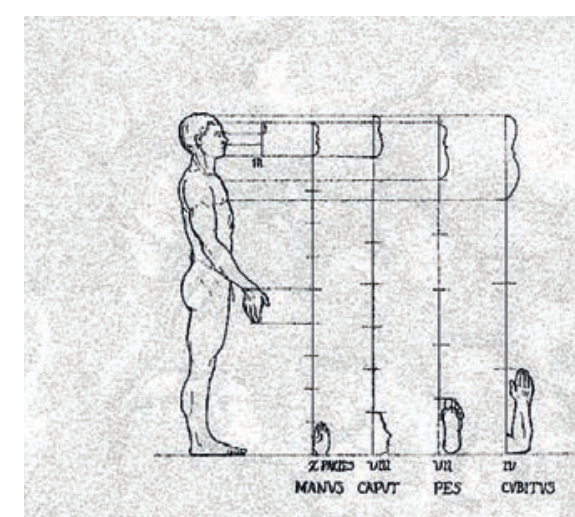

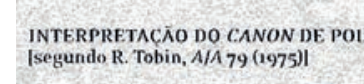
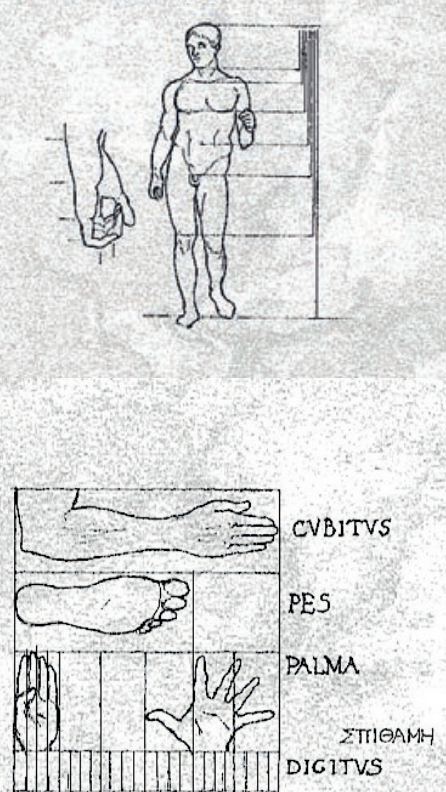

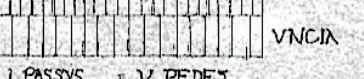

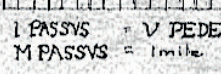

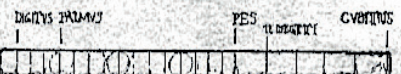
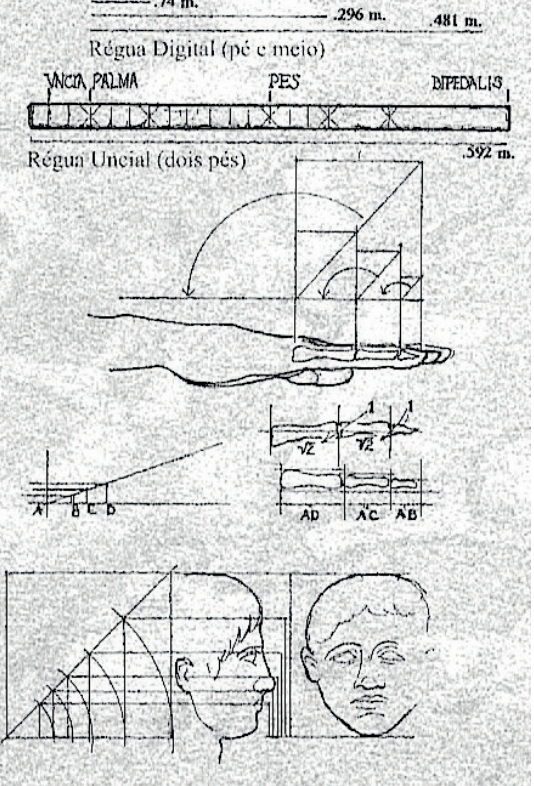

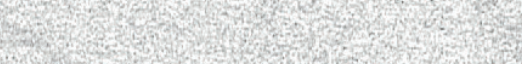
Fig. 134 - Unidades comuns de medida. Desenhos de Thomas Noble Howe. 
parece ter sido aplicada na largura da primitiva palestra das termas (fase1) (fig. 135).

Um terço de actus

Esta medida encontra-se, em primeiro lugar, na largura das faixas livres, tanto a norte como a sul do espaço central. Mas se pensarmos que o bloco das termas, que foi construído antes do forum, sofreu alterações aquando da construção do forum, repara-se que a palestra primitiva da primeira fase foi dividida em três compartimentos com sensivelmente um terço de actus (visto a largura total ser uma unidade de actus). Quando repetimos esta métrica, ao longo da faixa do forum obtemos um total de quinze terços de actus, ou seja, cinco actus.

Agora, se traçarmos uma diagonal no quadrado de um terço de actus que se encontra no canto nordeste do forum, junto à entrada das termas, adquire-se um eixo de viragem a $90^{\circ}$, onde se pode aplicar de novo a métrica de um terço, e imaginar como seria a possibilidade da existência de um pórtico na cabeceira do forum. 0 mesmo se pode aplicar no lado poente, simétrico a este (fig. 136).

\section{Um sexto de actus}

A métrica de um sexto de actus corresponde à medida de quatro passus descrita e detectada por Lino Tavares ${ }^{16}$ em diferentes pontos do forum (rever fig. 87, p. 81). Esses pontos são: a dimensão de largura e profundidade da abside quadrada no muro norte do forum e o intercolúnio central da plataforma comercial. Esta medida também é a metade do módulo de um terço, daí a abside quadrada ter metade da largura da faixa livre (fig. 137). Outra correspondência que se pode realizar com este módulo é a simetria de relação que há entre o lado sul e norte do forum que se situa no eixo de simetria transversal (fig. 138).

Um quarto de actus

A medida de um quarto de actus corresponde a seis passus, medida também ela detectada por Lino Tavare ${ }^{17}{ }^{17}$ como largura e profundidade da abside quadrada da plataforma comercial, e como largura da dita plataforma (rever fig. 87, p. 81). Mas esta revela-se de outras formas no conjunto. Também se verifica na cabeceira poente do forum, num espaço que ocupa quatro quadrados de um quarto de actus, organizados de forma linear; verifica-se no espaço das fornaIhas nas termas; e quando pensamos na plataforma comercial como

${ }^{16}$ Lino Dias, "Urbanization and architecture on the outskirts of the Roman Empire", in Roma y las provincias: modelo y difusión, 2011, pp. 707-713.

${ }^{17}$ Ibidem.
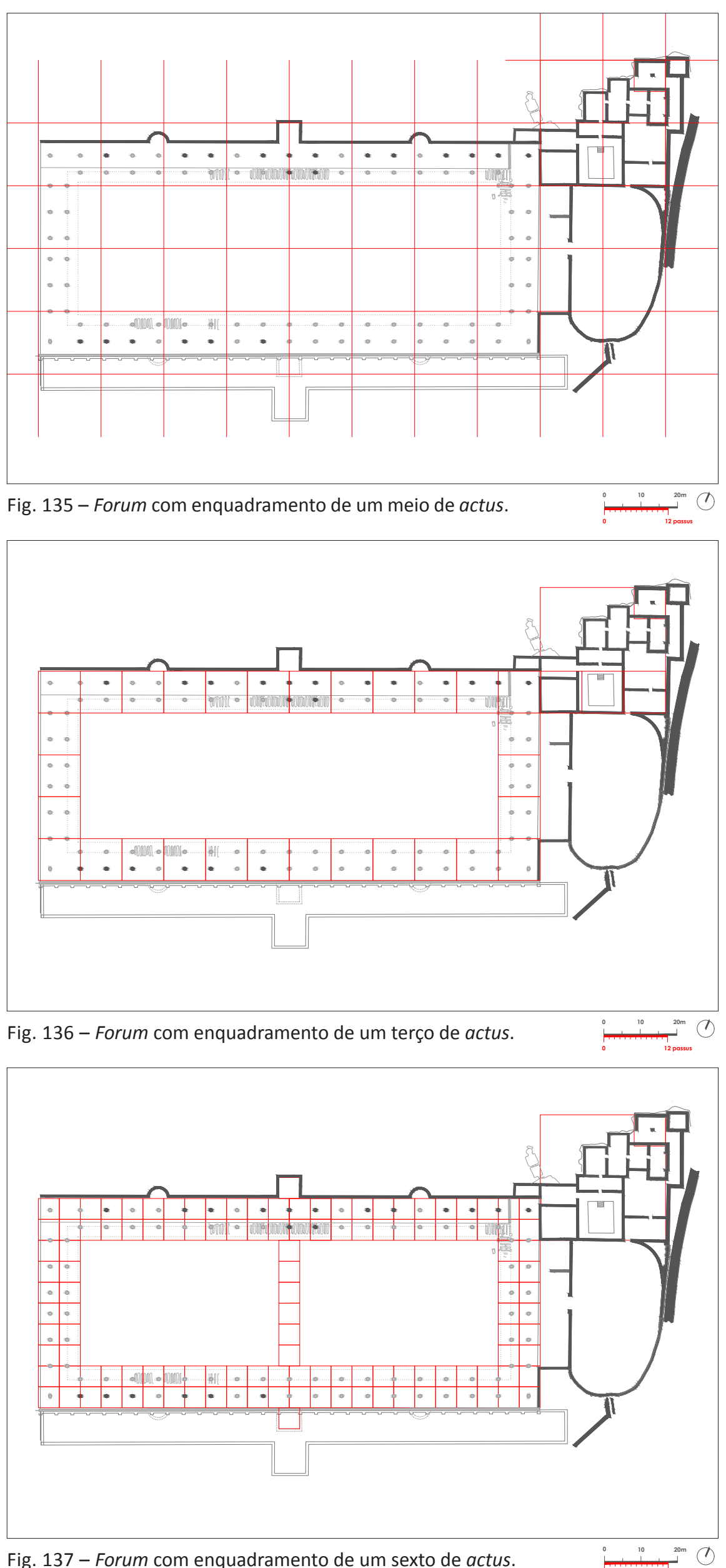

Fig. 137 - Forum com enquadramento de um sexto de actus.

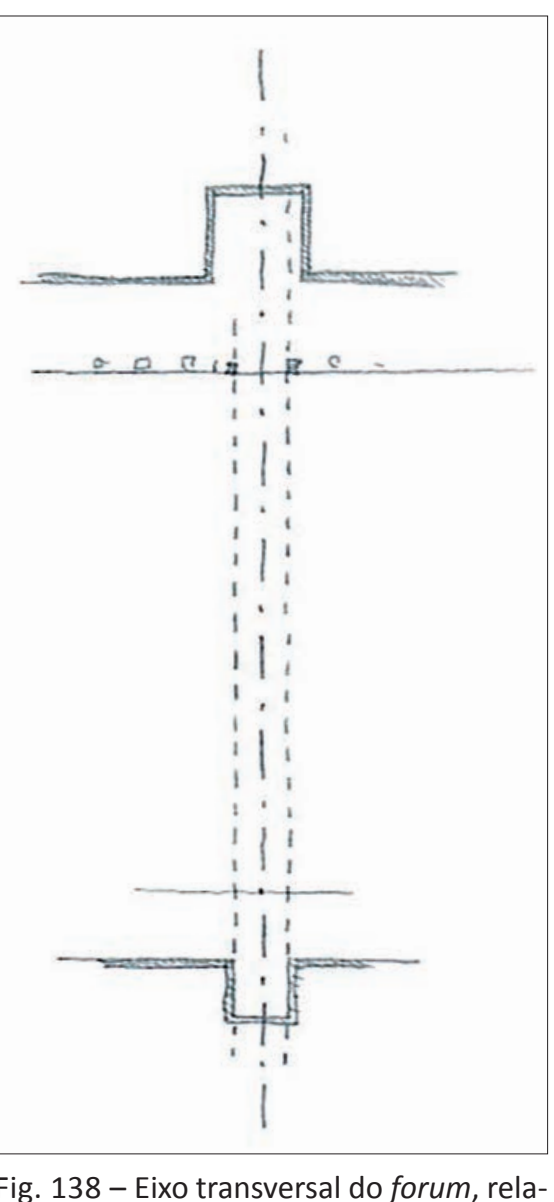
ção de larguras entre o muro norte e sul. 
uma banda de quadrados de um quarto de actus de lado, este ocupa cerca de dezassete unidades.

A reflexão em torno desta plataforma conduz ao raciocínio de aplicabilidade do módulo de um quarto no espaço do forum. Se pensarmos na experiência anterior, realizada com a unidade de um terço, e se considerasse essa a largura da área coberta, a nível estrutural, havia a exigência de uma consola que sobressaía ao segundo alinhamento de colunas. Apesar desta solução ser agradável visualmente (pois essa beirada alinharia, tanto a norte como a sul, com a largura da cabeceira poente), parece pouco provável que assim acontecesse. Portanto, quando se aplica a unidade de um quarto sobre os duplos porticados referidos anteriormente, verifica-se que, desde os paramentos limite (norte e sul) até ao abarcar da largura do alinhamento da segunda colunata, a largura é de um quarto; o mesmo que na plataforma comercial sul. Este dado poderá corresponder à largura da área coberta deste porticado; o mesmo se aplicaria ao porticado nascente e poente.

Uma curiosidade dos pórticos das cabeceiras é que quando aplicada a unidade de um quarto, quando se aproxima do eixo de simetria longitudinal, o espaço restante não corresponde à largura de um quarto, mas sim de um sexto; a medida detectada tanto a norte como a sul do eixo transversal (fig. 139).

\section{Um oitavo de actus}

A unidade de um oitavo de actus equivale a três passus, medida que Lino Tavares associou à métrica do intercolúnio da plataforma comercial sul, à entrada do forum a nascente, e ao diâmetro das ábsides do muro norte do forum ${ }^{18}$.

Esta unidade corresponde a metade da unidade um quarto, que foi detectada como largura da plataforma sul e cabeceira do forum. Assim, tanto o intercolúnio da plataforma como a entrada do forum correspondem a metade da largura dos seus espaços (fig. 140).

Cinco por cinco passus (25×25 pés)

Ao contrário das restantes unidades até aqui expostas, o módulo de cinco passus não corresponde a uma fracção do actus, mas vem responder ao ritmo da disposição das sapatas de coluna encontradas no forum. Esta medida permite situar os apoios para as colunas a todo o comprimento do forum, em que os elementos-chave da sua utilização são a localização de um apoio ao eixo de cada abside ${ }^{19}$ (fig. 141).

${ }^{18}$ Lino Dias, “Urba

architecture on the outskirts of the Roman Empire", op.

Um exemplo onde esta composição ocorre é no forum de Bavey (fig. 142).
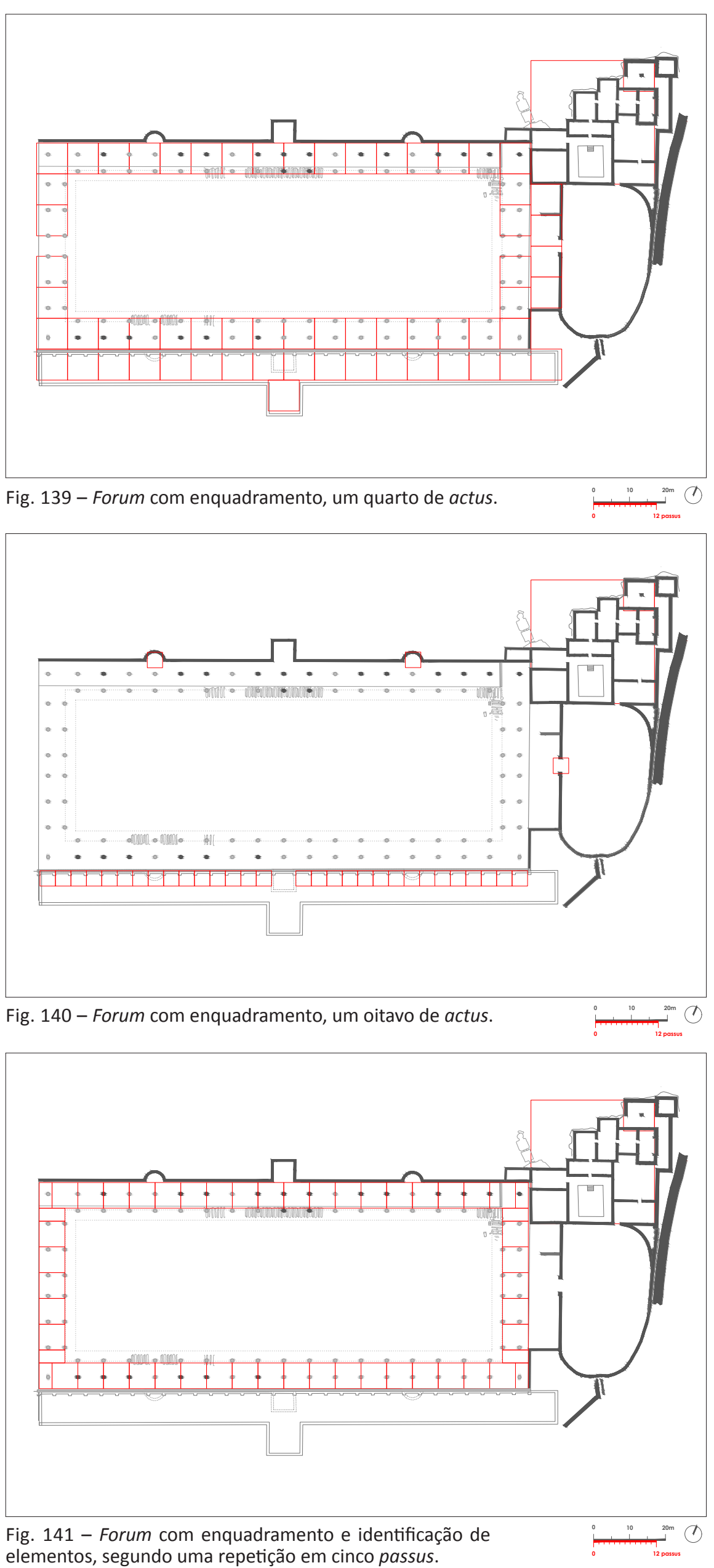

ig. 141 - Forum com enquadramento e identificação d
elementos, segundo uma repetição em cinco passus.

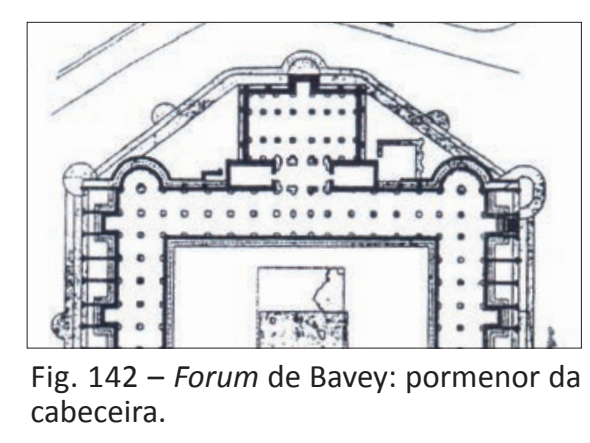




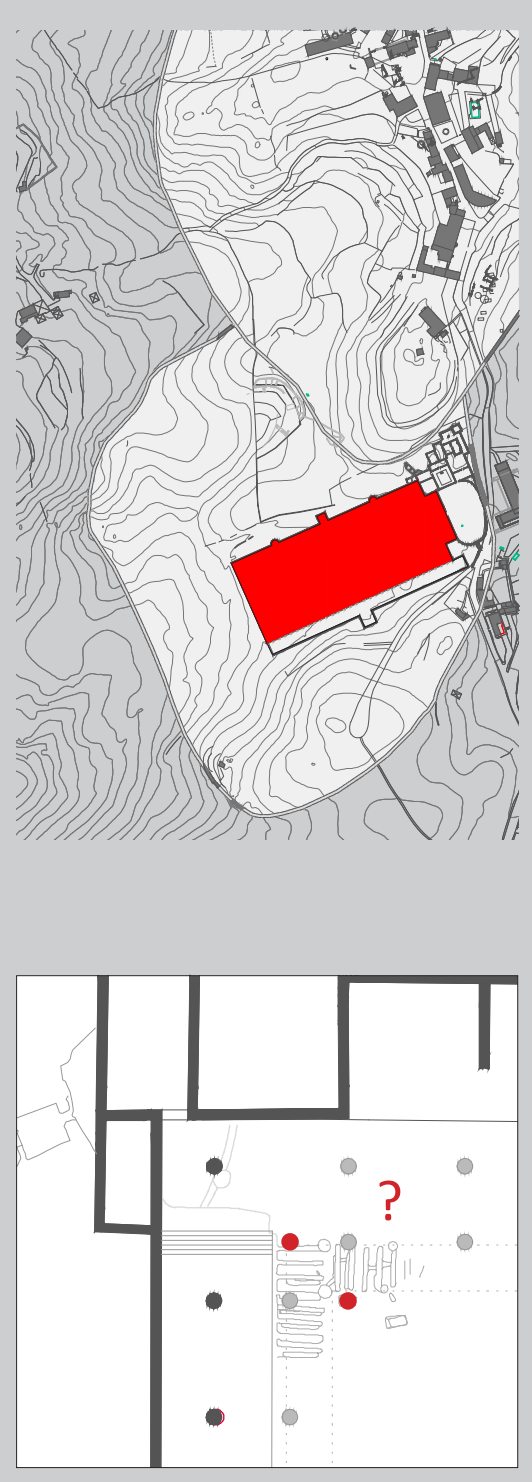

Fig. 143 - Identificação da problemática no canto nordeste do forum ções possiveis.

\subsection{5 - Colunas}

De acordo como o referido sobre a viragem das colunas, quando pensamos na forma como os porticados se encontravam nas extremidades do forum, surgem aparentes incoerências.

Ao seguir a repetição da colunata, nos cantos, mais especificamente no canto nordeste onde foi encontrada uma sapata, a coluna situa-se a uma maior distância que as anteriores. Outro problema é o encontro da segunda colunata do pórtico norte com a colunata do pórtico nascente, em que, segundo a métrica existente, não há coluna no canto (fig. 143).

Para solucionar este problema, uma hipótese que nos ocorreu foi que o segundo anel das colunas, em todo o forum, teria que duplicar, por forma a existir uma coluna que ocupasse esta posição. Isto explicaria o maior afastamento da cavidade encontrada (fig. 144)

De acordo com esta ideia, encontrámos dois exemplos onde esta duplicação de colunas ocorre. Os exemplos que encontrámos foram a reconstituição do forum de César, em Roma, segundo Ch. Morselli e E. Tortorici (fig. 146), e o forum/agora de Smyrne, na Turquia (fig. 147).

Outra solução possível iria de encontro com o ensaio realizado com a unidade de um terço de actus, onde se propõe imaginar um terceiro anel de colunas (fig. 145).

Aqui, o princípio assemelha-se com o forum/agora de Smyrne na Turquia, em que existem dois alinhamentos de colunas ao centro, e uma terceira colunata com intercolúnio mais fechado. Este princípio, quando aplicado a Tongobriga, segundo as diferentes métricas usadas, torna possível desenhar esta hipótese, sem que haja qualquer problema no desenho dos cantos. Esta hipótese deixa livre uma área que corresponde à largura do actus.

Outra vantagem desta solução é que parece explicar a existência de duas cavidades sobre os talhes do afloramento do canto nordeste (fig. 148).

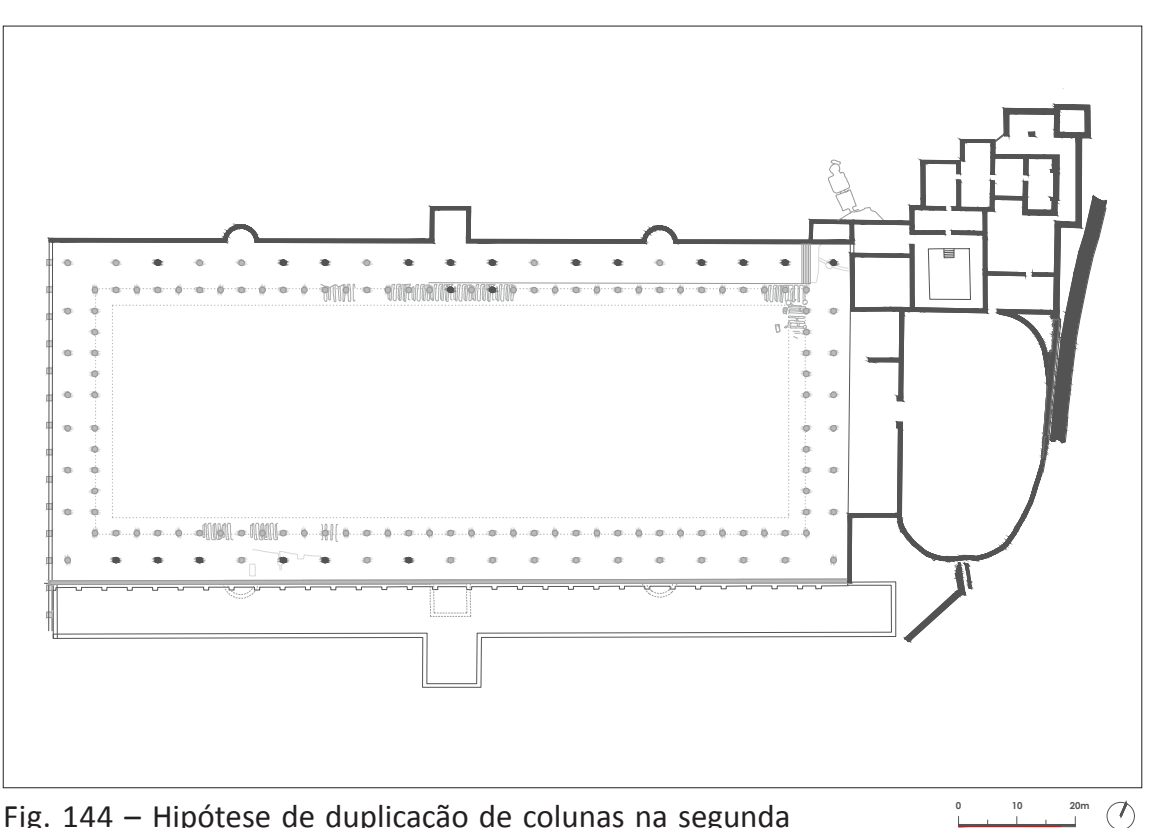

ig. 144 - Hipótese de duplicação de colunas na segunda

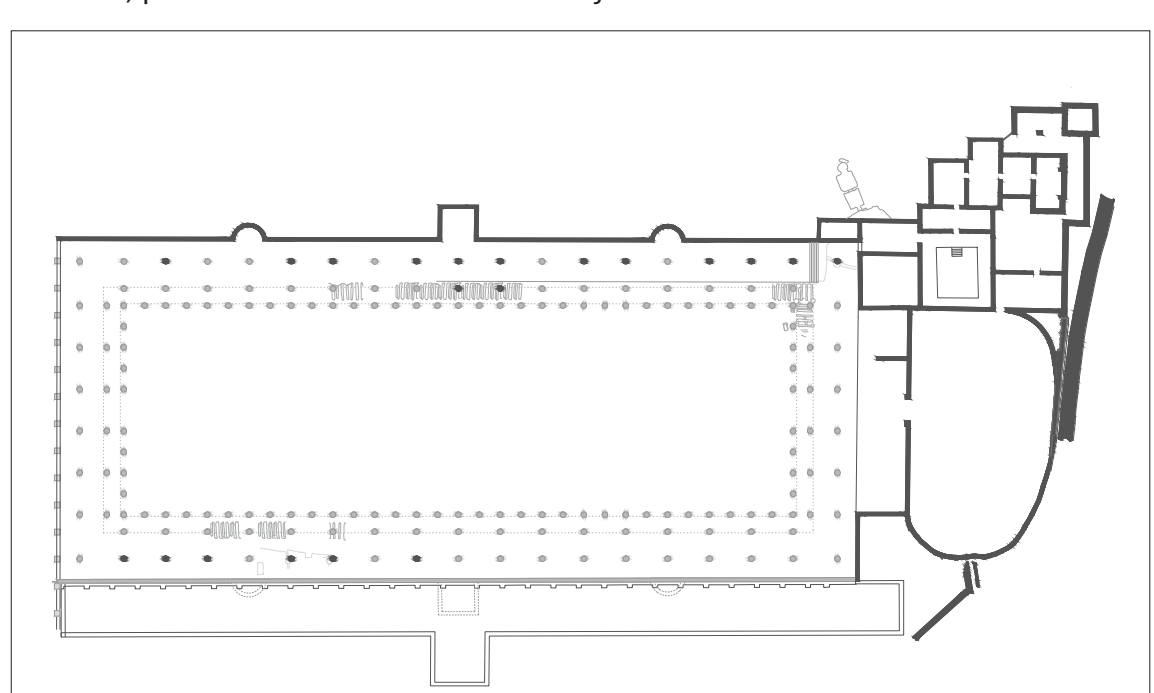

Fig. 145 - Hipótese de um terceiro pórtico, e a duplicação de colunas em relação à segunda.

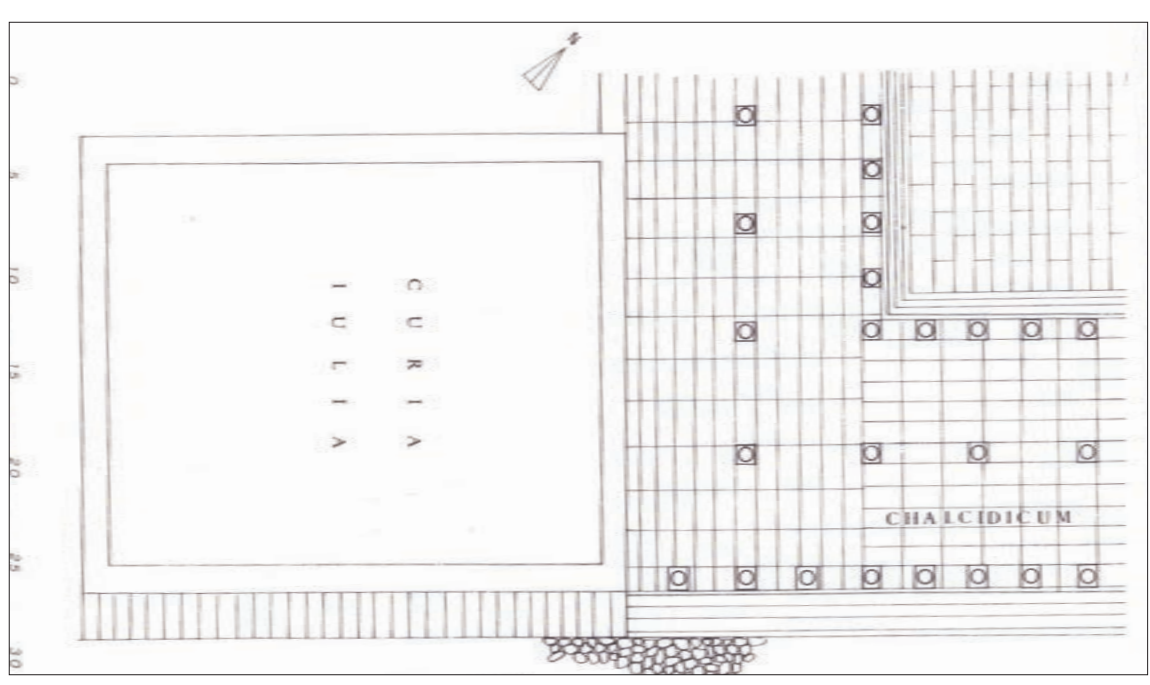

ig. 146 - Plano de reconstituição do ângulo meridional, do forum de César em Roma, segundo Ch. Morselli et E. Tortorici.

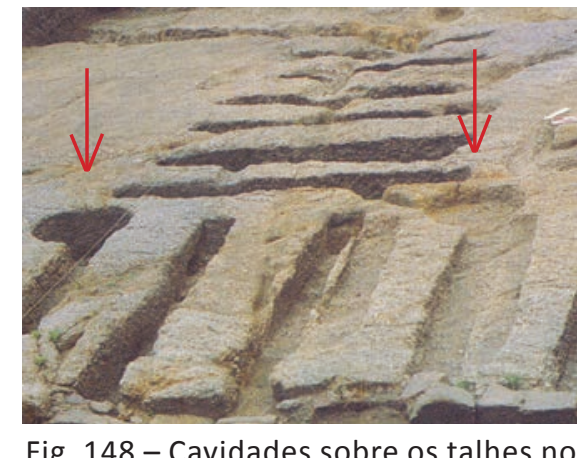
Fig. 148 - Cavidades sobre os talhes no afloramento, canto nordeste do forum.

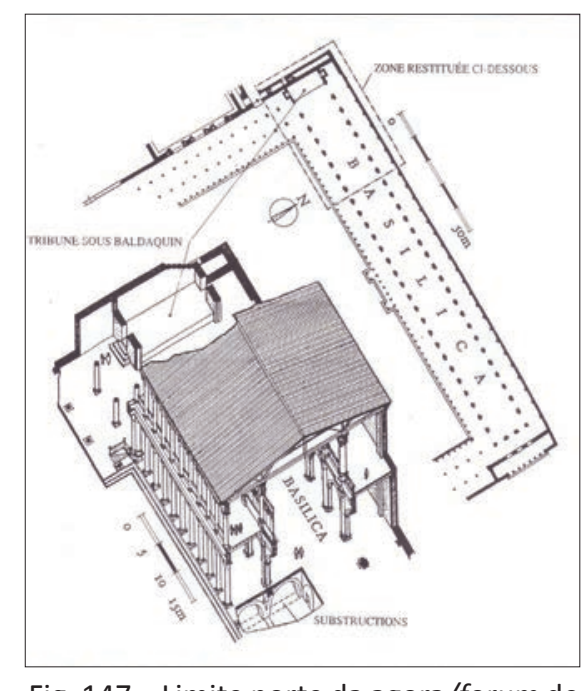

Fig. 147 - Limite norte da agora/forum de Smyrne, na Turquia, onde se situa a basí-
lica Reconstituição segundo, $J-B$, Ward Perkins. 


\subsection{6 - Praça}

Para o desenho da praça do forum, Vitrúvio ${ }^{20}$ descreve que esta deveria de ser oblonga (dois terços); a partir desse princípio, voltamos a analisar as hipóteses de disposição dos pórticos apresentados; em que, para cada uma das hipóteses levantada, obtemos um desenho de praça distinto.

Assumindo a disposição e aplicação da unidade de um terço de actus no espaço do forum (disposição de três pórticos), toma-se o espaço livre, na transversal, como largura da praça. Assim, a partir da regra de dois terços de Vitrúvio, aplica-se o rectângulo que corresponderia a esse espaço sobre o forum, por forma a perceber onde este terminaria. O mesmo princípio é aplicado considerando a largura livre deixada pela aplicação da unidade de um quarto de actus (disposição de dois pórticos).

Desta forma, na primeira situação (unidade um terço), a praça teria a largura de um actus, sendo assim o seu comprimento actus e meio (36×24 passus). A praça teria início no limite do pórtico nascente, até antes do eixo transversal; mantendo-se, desta forma, totalmente dentro da metade do forum (fig. 149). Esta solução agrada-nos, por um lado, pois assim existe uma distinção clara entre o espaço da praça e o espaço religioso (que se define a eixo das absides quadradas); por outro lado, reforça a ideia de um pórtico com três linhas de coluna para o forum.

Já na segunda situação, com a unidade de um quarto de actus, onde se tem em consideração a hipótese de pórticos laterais de duas colunas, a configuração da praça não convence. Esta teria a largura de 28 passus (quatro passus maior que um actus), o que corresponderia a um comprimento de 42 passus. A posição deste rectângulo, no forum, teria início no limite do pórtico nascente, e fim no eixo transversal do forum. Esta segunda hipótese vai-se aplicar ao eixo das absides quadradas, o que a torna pouco provável (fig. 150).

A única forma da disposição de dois pórticos resultar, numa praça que se adapta a esta situação, seria se existisse uma combinação de ambas as experiências anteriores.

Esta hipótese de desenho corresponderia a uma mistura de ambas as métricas, por forma a responder a diferentes princípios presentes neste forum. 20 "A sua largura será definida de modo a que tenha duas partes das três em que for
dividido o comprimento. Assim, deste modo, a sua planta será oblonga e a sua disposição útil para a realização de espectáculos". Vitrúvio V, 1, 2. Tradução de Justino Maciel.
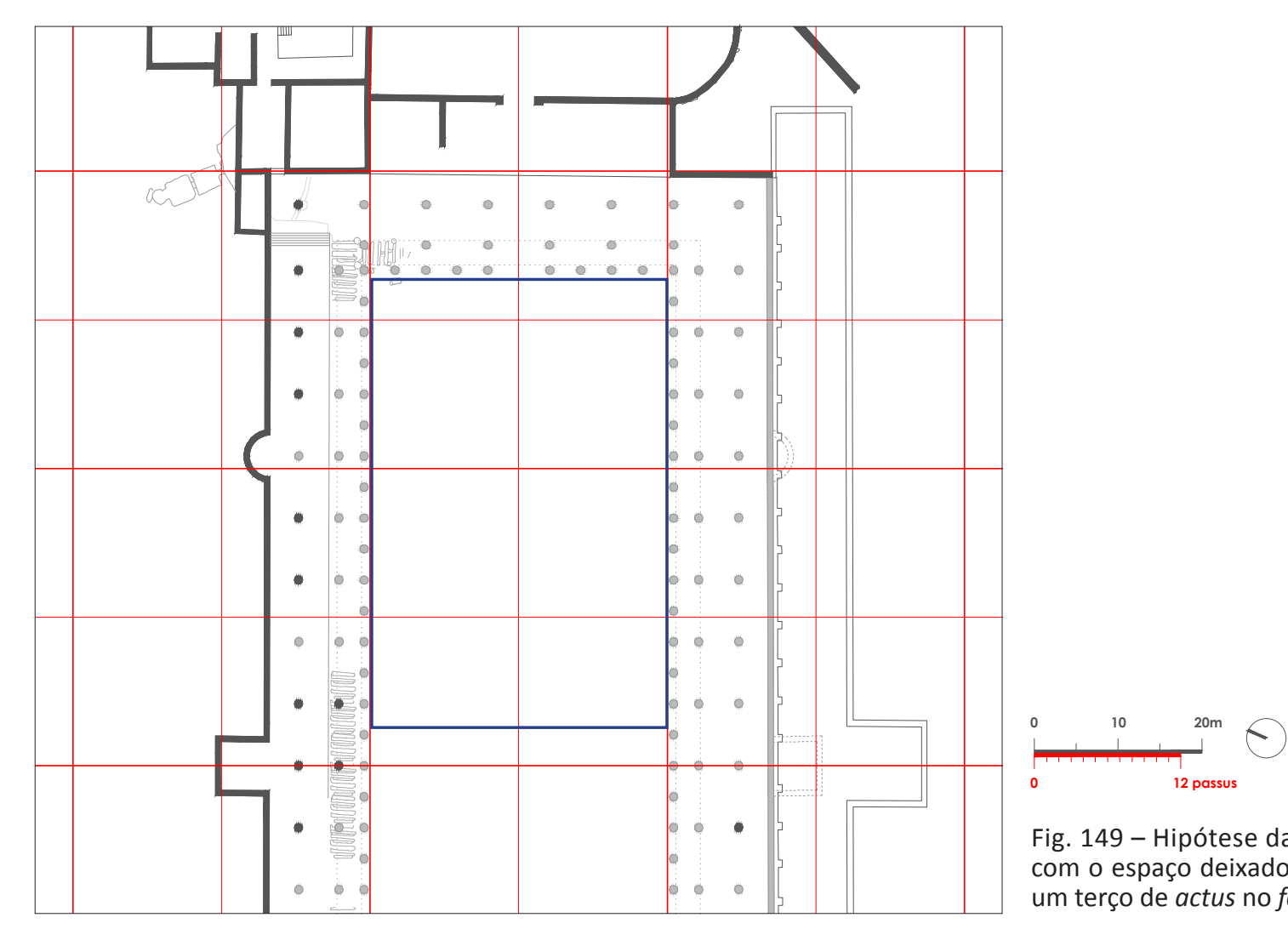

Fig. 149 - Hipótese da praça, de acordo
com o espaço deixado pela aplicaçãa de um terço de actus no forum.
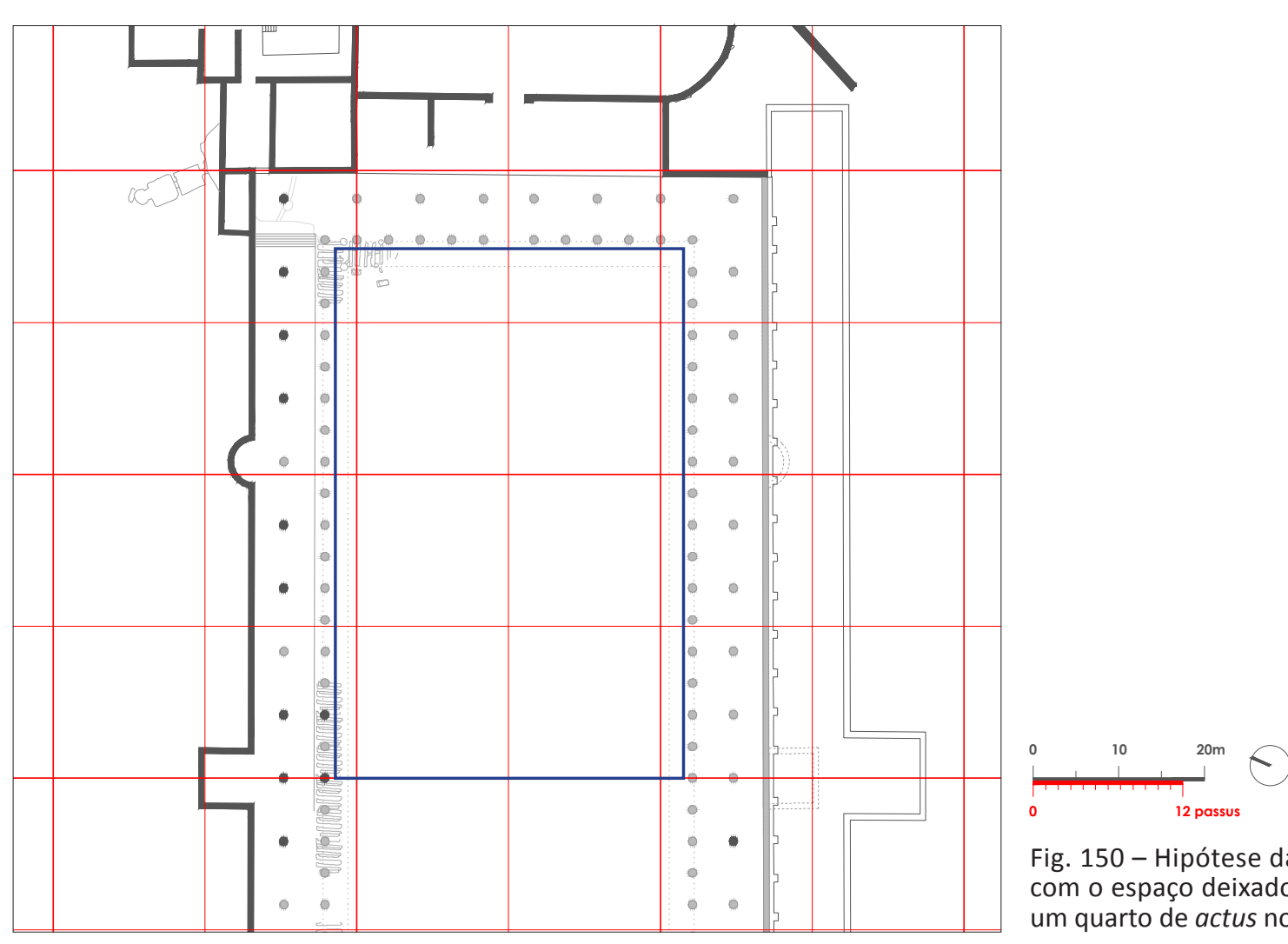
Fig. 150 - Hipótese da praça, de acordo
com o espaço deixado pela aplicação de um quarto de actus no forum. 
Assim, na situação da praça, ambas as métricas teriam um pape no desenho do forum. A unidade um quarto define a largura da áre coberta do duplo pórtico, e a unidade de um terço define o limite da área para a praça. Desta forma, a diferença criada entre ambas corresponderia a uma largura de dois passus que estaria destinada a degraus e/ou um pavimento distinto mais elevado (fig. 151) ${ }^{21}$. Uma situação comum em outros fora, como o forum de Conimbriga (fig. 153 e 154) e o forum de Ampurias (fig. 152).

O problema é que, apesar de esta linha de raciocínio parecer aceitável, surgem duas inconsistências. Primeiro, o problema que se levantou atrás, na viragem dos pórticos, pois a solução estrutural do canto, só com duas linhas de colunas, é pouco lógica. Depois, segundo referência de Lino Tavares, até agora não se encontraram elementos arqueológicos que comprovem qualquer desnível destinado a degraus, ou qualquer pavimento elevado na praça.

É desta forma que, em suma, a solução dos três pórticos se torna cada vez mais fundamentada, pois dentro destas duas hipóteses a praça de um actus por actus e meio é o que se apresenta como o mais provável (rever fig. 149).

${ }^{21}$ Outra justificação é que, desta forma, se evita a sobreposição da praça aos talhes paralelos no afloramento denitico destinados à a sonagem, eque se tornar a praça (fig. 149).
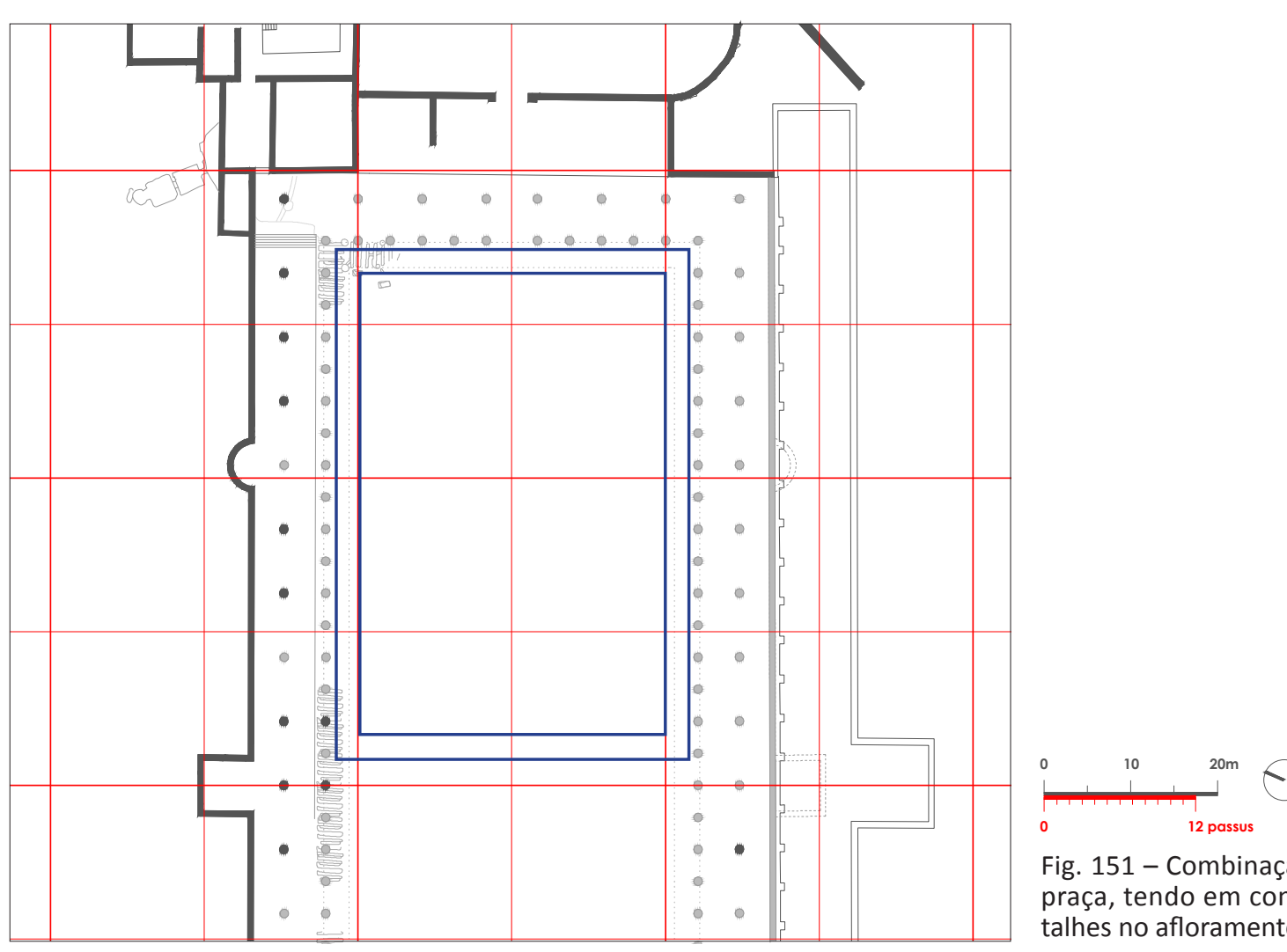

Fig. 151 - Combinação das hipóteses de praça, tendo em conta a disposição dos talhes no afloramento granítico.

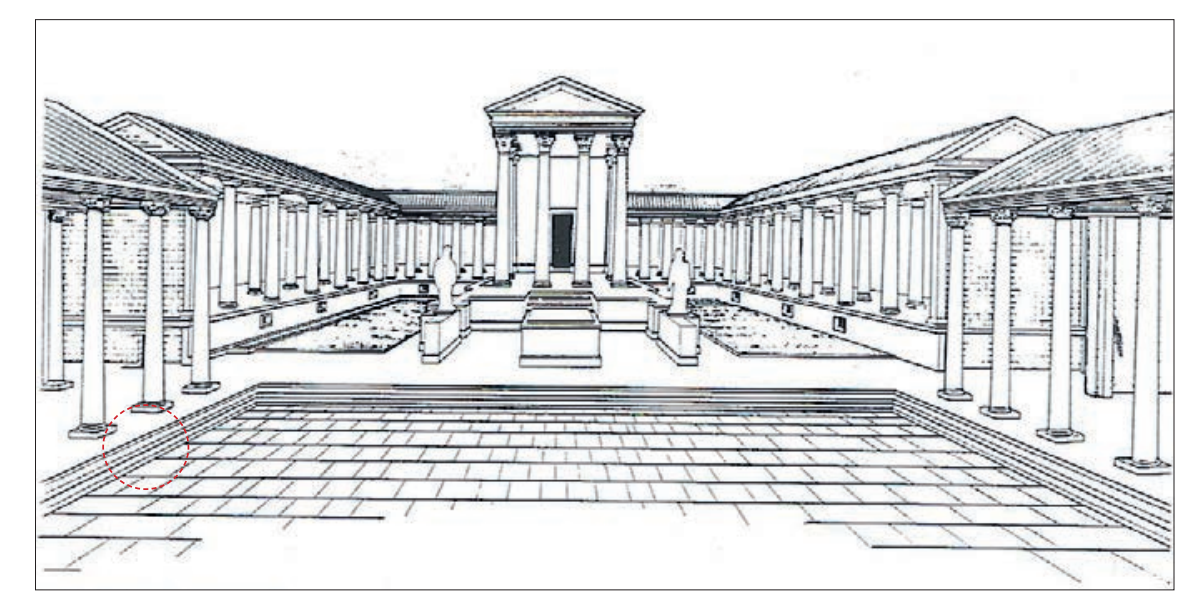

Fig. 152 - Illustração do forum de Ampu-

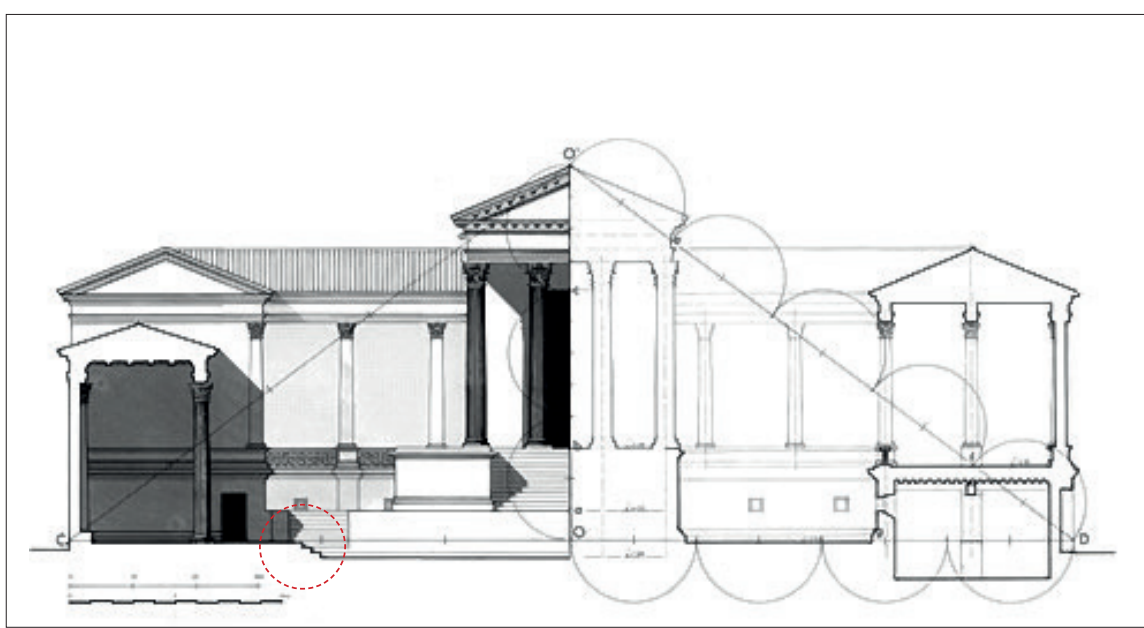

Fig. 153 - Forum de Conimbriga. Corte transversal com indicação proporcional do templo em relação ao espaço livre.

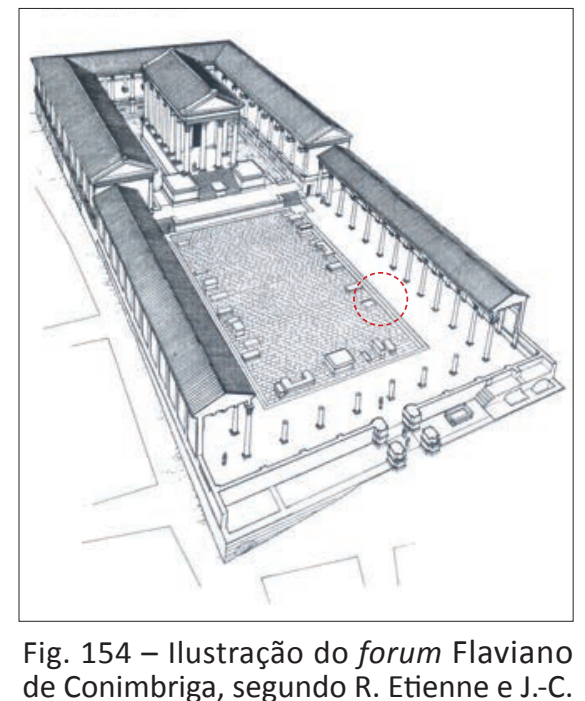
Golvin. de Conimbriga, segundo $R$. Etienne e J.-C. 


\subsection{7-Templo}

Uma vez lançadas as hipóteses de composição para o forum, a nível de pórtico e praça pública, resta-nos especular sobre uma lógica de ocupação no espaço religioso. Segundo o realizado atrás, procura-se perceber o desenho e o enquadramento do templo e o espaço existente entre este e a praça (fig. 156).

Sabe-se que o templo existia, pois ainda permanece no local um conjunto de pedras que pertenciam à sua base. Infelizmente, não se sabe a sua posição exacta, porque poucos anos antes do início das escavações, um lavrador removeu, com recurso a maquinaria, o pouco que restava do templo (fig. 155) ${ }^{22}$.

Por comparação a outros fora, chegou-se à conclusão de que, na maior parte dos casos, o templo tem cerca de um terço da largura livre entre porticados. Alguns desses casos são o forum de Conimbriga, Miróbriga, Feurs, Clunia ${ }^{23}$, o forum de Augusto em Roma, o Italica entre outros (fig. 158).

Quando aplicado este principio ao forum de Tongobriga, se considerarmos a largura dos pórticos com seis passus (duas colunatas), um terço do espaço livre não corresponde a um número inteiro. Se considerarmos a largura dos pórticos com oito passus (três colunatas), o espaço livre restante corresponde a um actus (largura da praça). E como um terço corresponde a oito passus, o templo teria igualmente oito passus, assim como o espaço deixado de cada lado (fig. 157), o que reforça a hipótese das três colunas, apresentada atrás.

No que diz respeito à sua posição longitudinal, quando analisamos outros fora, o espaço deixado atrás (entre o templo e o pórtico), pode ser igual ao deixado ao lado (caso de Italica e Feurs [fig. 158]), ou então corresponder a três quartos dessa medida (caso de Conímbriga e de Bavey [fig. 158]).

Para a proporção do templo considerou-se o dobro da largura para o comprimento 2:1.

Quanto ao espaço entre o eixo transversal do forum e o templo, este poderá ter sido, certamente, destinado a canteiros e/ou estatuària, com escadarias que fariam chegar ao templo.

22 "Em 1977, também um podium foi desmontado pelo lavrador, com recurso a maqunaria. Muitos elementos desapareceram mas algumas das grandes pedras permande Tongobriga", op cit, 1999, p. 89.

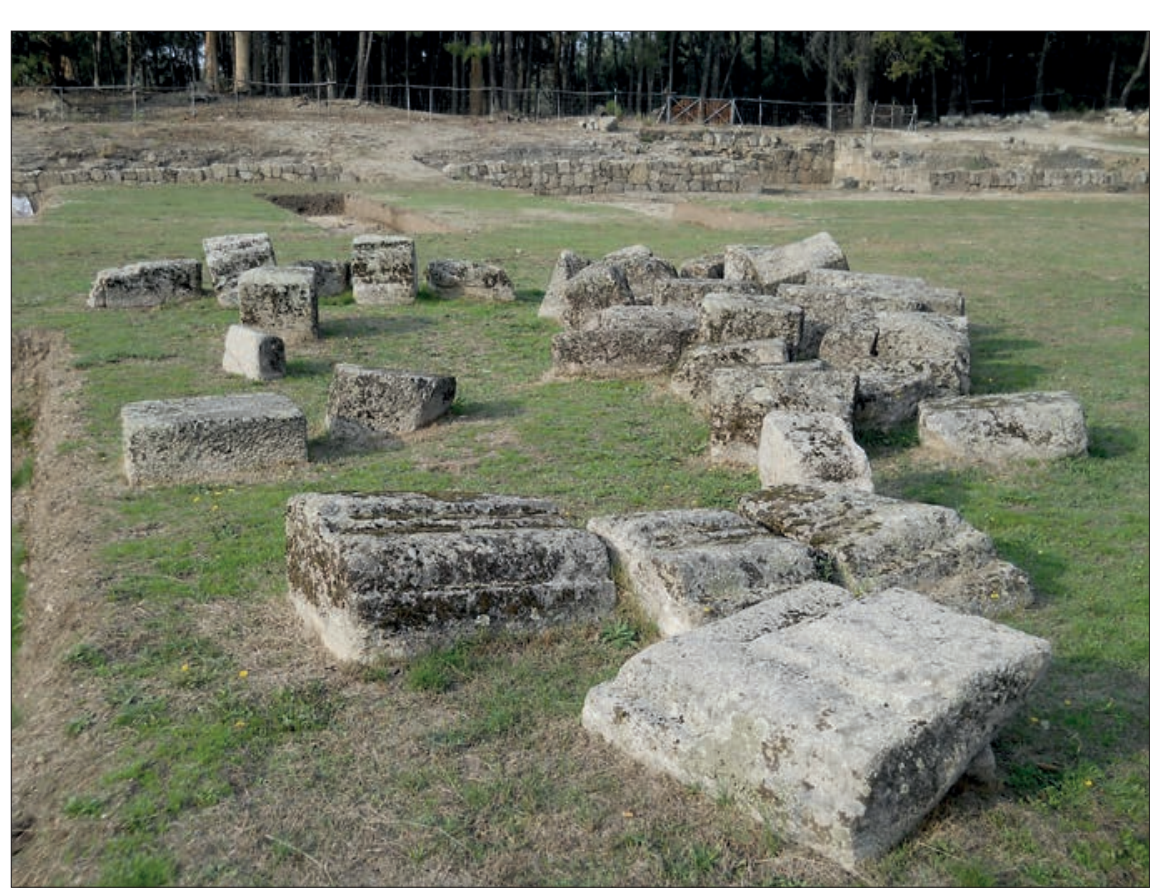

Fig. 155 - Conjunto de pedras que terão pertencido ao templo.

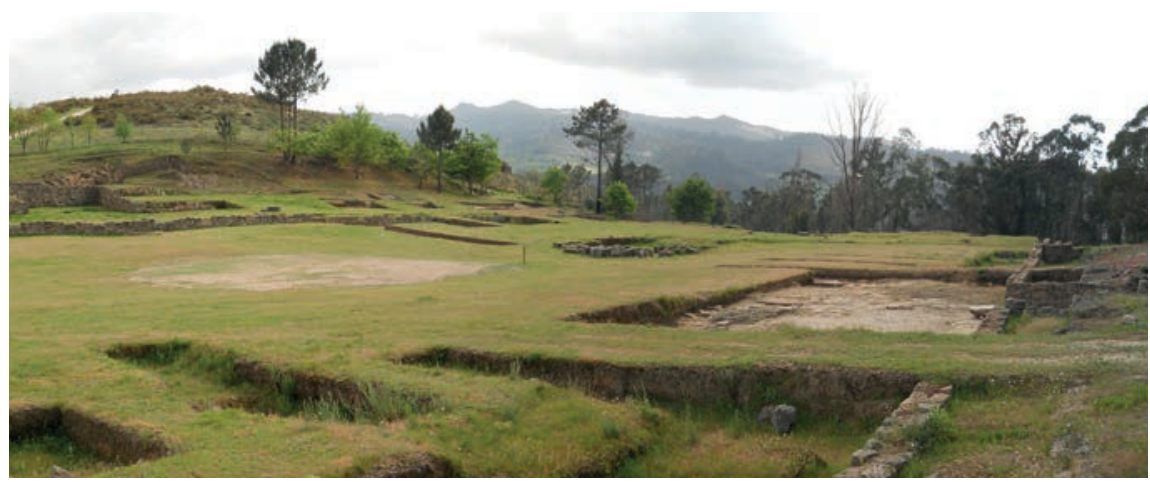

fig. 156 - Espaço religioso, onde o templo se encontrava.
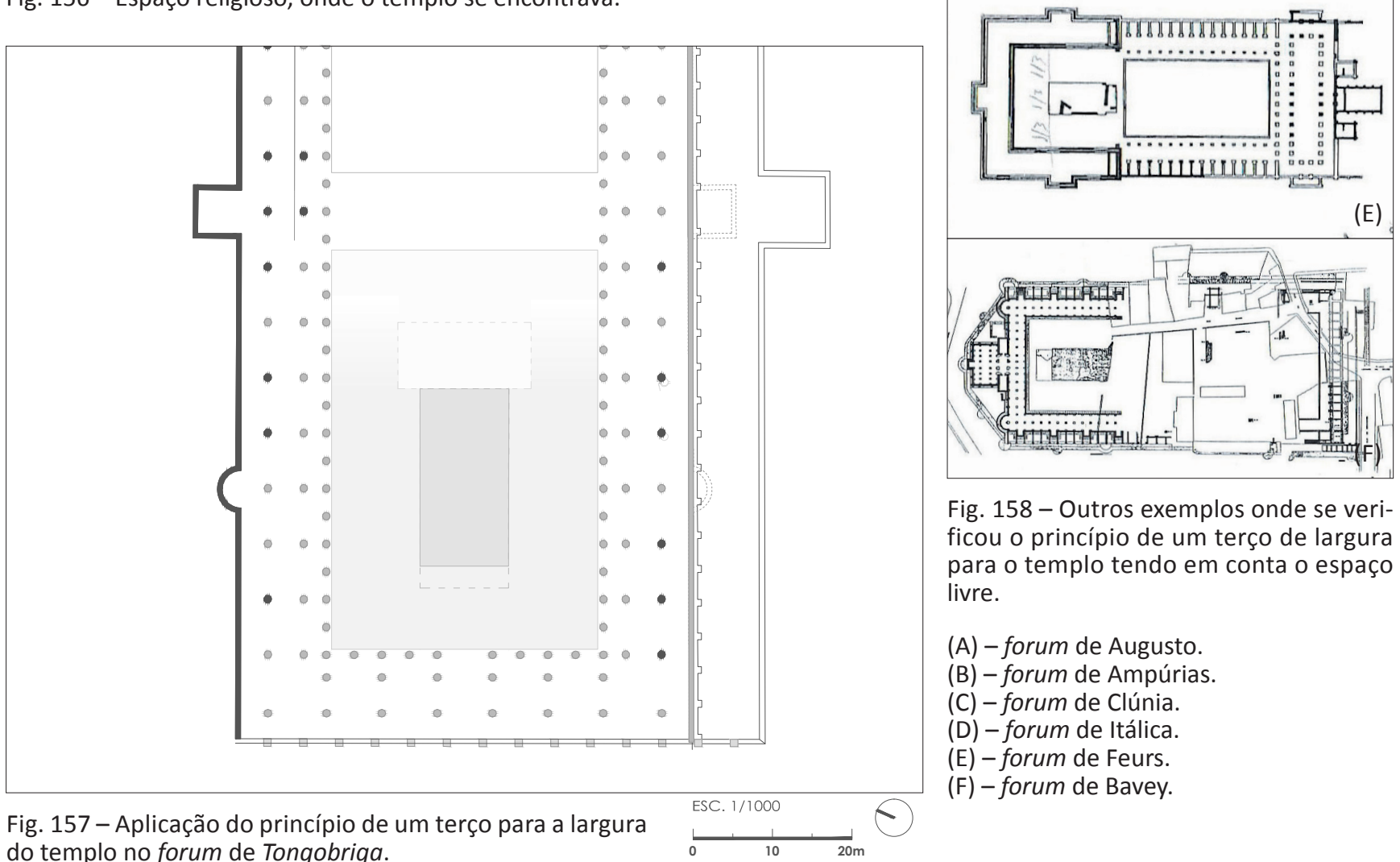

(E)

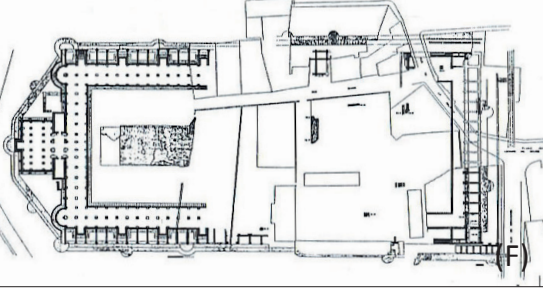

Fig. 158 - Outros exemplos onde se verificour o principio de um terço de largura livera o templo tendo em conta o espaço

(A) - forum de Augusto.

B) - forum de Ampurias.

(D) - forum de Itálica.

(E) - forum de Feurs.

(F) - forum de Bavey. 


\section{$-4$ \\ 2.2.8 - Proposta de desenho e enquadramento do forum}

Em resposta às hipóteses lançadas, chega-se a uma proposta integral para o desenho do forum (fig. 159). Esta reúne todos os elementos que foram estudados individualmente, por forma a compreender a composição do forum como um todo.

A hipótese apresentada é a que melhor se fundamenta a partir da interpretação dos vestígios; mas não deixa de estar dependente de confirmação a nível arqueológico.

Esta reconstituição corresponde à primeira fase do forum, tendo em conta que a plataforma comercial foi construida numa fase posterior $^{24}$. A partir deste dado, foi possível, com o auxílio do enquadramento na grelha actus, e o estudo da posição das sapatas de coluna, reconstituir a simetria deste espaço, e determinar os elementos em falta.

Apontamos assim: as colunas em falta; os pórticos norte e sul a proposta de pórticos a nascente e poente, mais a hipótese de uma colunata com o dobro das colunas, e que vai de encontro aos vestígio do canto nordeste; e, por fim, os espaços da praça e templo que correspondem à aplicação da grelha actus.

O desenho do forum resulta assim num amplo espaço, porticado por quatro pórticos de três colunas, em que o seu corpo centra se divide em dois; o espaço da praça e o espaço do templo; em que no meio existe uma clara relação visual entre as duas absides quadradas.

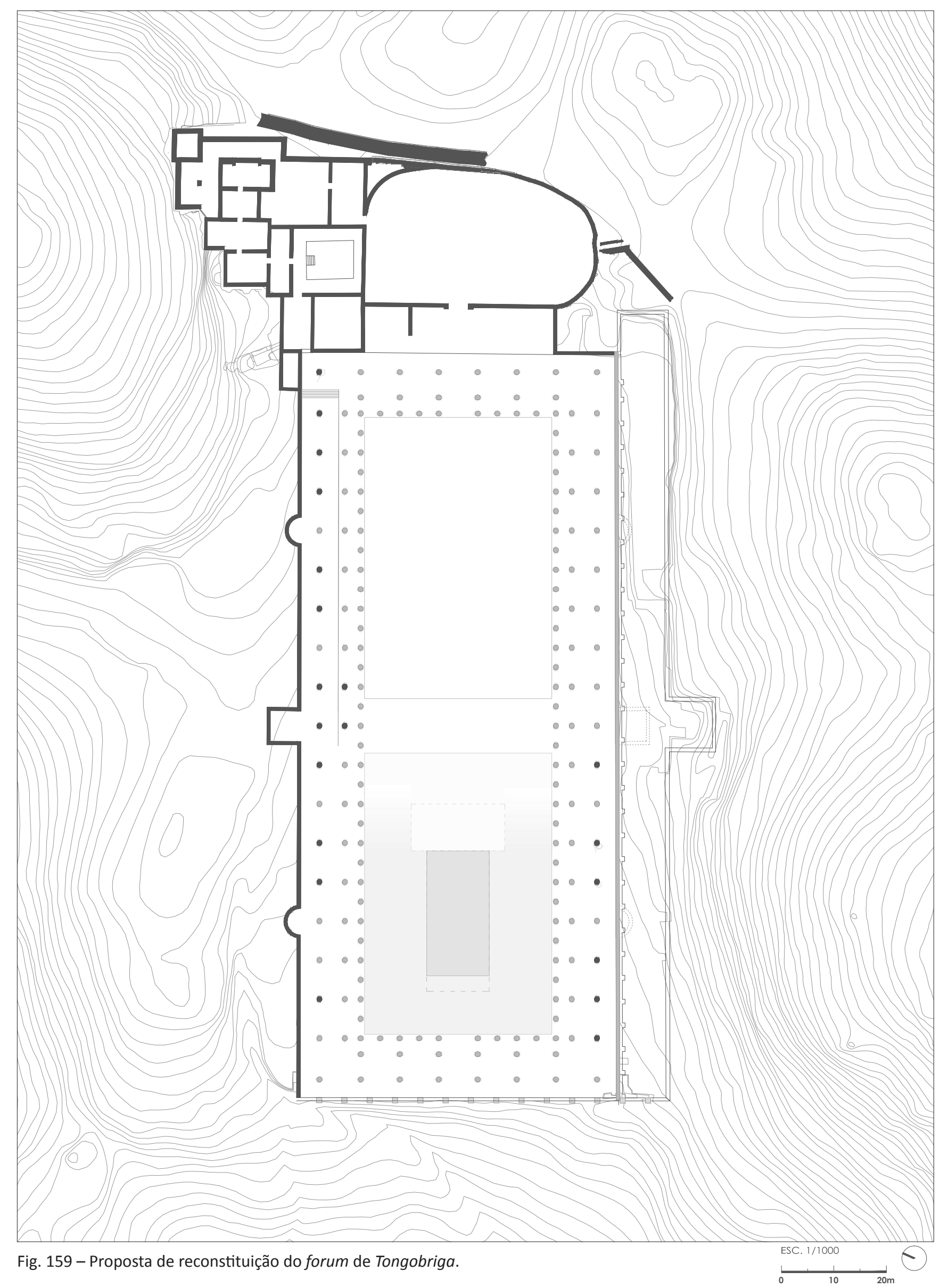

${ }^{24}$ Dados arqueológicos comprovam esta teoria. 


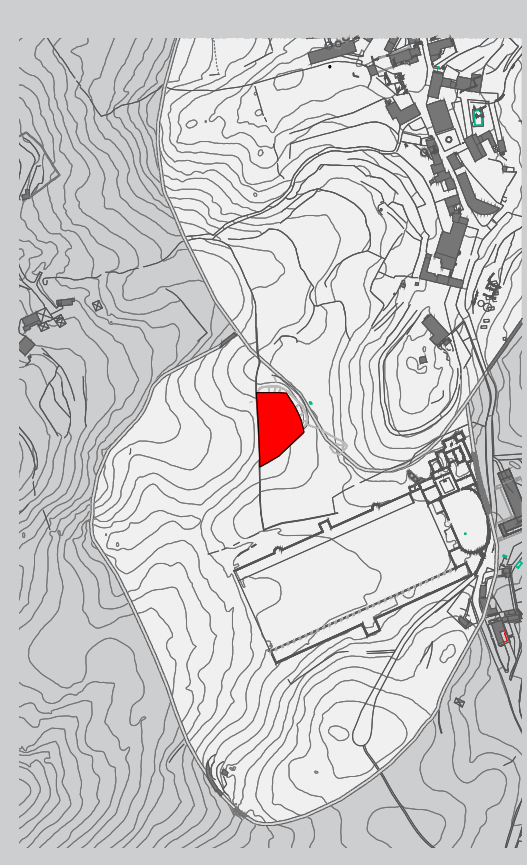

\section{3 - Teatro Romano}

O teatro é aquele equipamento que podia realmente representar a aculturação romana numa cidade de província, dadas as suas características e o estilo de peças, que eram baseadas no quotidiano da vida romana. A sua dimensão não teria que ser exactamente proporcional à cidade, podendo assim aglomerar mais espectadores do que o número de habitantes da cidade. Este facto relaciona-se com característica de centro de atracção que se atribui a Tongobriga.

\subsection{1 - Localização}

Antes de se chegar à actual hipótese de implantação, outros locais foram averiguados pela equipa de investigação; mas o conjunt de socalcos que se encontravam junto ao forum chamaram a um maior atenção aos investigadores. Esta localização estava favorecida pela topografia, pela orientação solar, pelas qualidades de propagação acústica, ficando assim apontada como localização mais plausível do Teatro Romano de Tongobriga (fig. 160, 161 e 162).

Lino Tavares explica a sua localização, em 1997, da seguinte forma: "Atravessado o forum segundo o seu eixo menor, caminhava-se sem esforço no Cardo ao longo dos cerca de 1000 metros de comprimento, já que foi traçado sempre entre os $312 \mathrm{~m}$ e $320 \mathrm{~m}$ de altitude, e a subida, apesar de ligeira, só se fazia sentir a partir do espaço onde se situaria o teatro. Estava bem integrado, construído de modo a aproveitar a morfologia dos afloramentos graníticos. Identificámo-lo através da análise da morfologia do terreno e confirmámo-lo nas observações em fotografia aérea. Situava-se na encosta poente, junto ao Cardo, foi construído de modo a aproveitar a morfologia dos afloramentos graníticos, permitindo o acesso directo através daquele à zona superior da cávea, característica observada em vários outros teatros roma nos (LARA, 1992, 153). Ocupava a área de $1100 \mathrm{~m}^{2}$, com um diâmetro da cerca de 52 metros, algo semelhante ao observado na estrutura dos teatros romanos indígenas da Gália (HARMAND, 1990, 395), reforçando, assim, a ideia de que os Romanos se serviam também desta 'arma cultural de raiz mediterrânica' para persuadir as populações locais $(\ldots)^{\prime \prime}$.

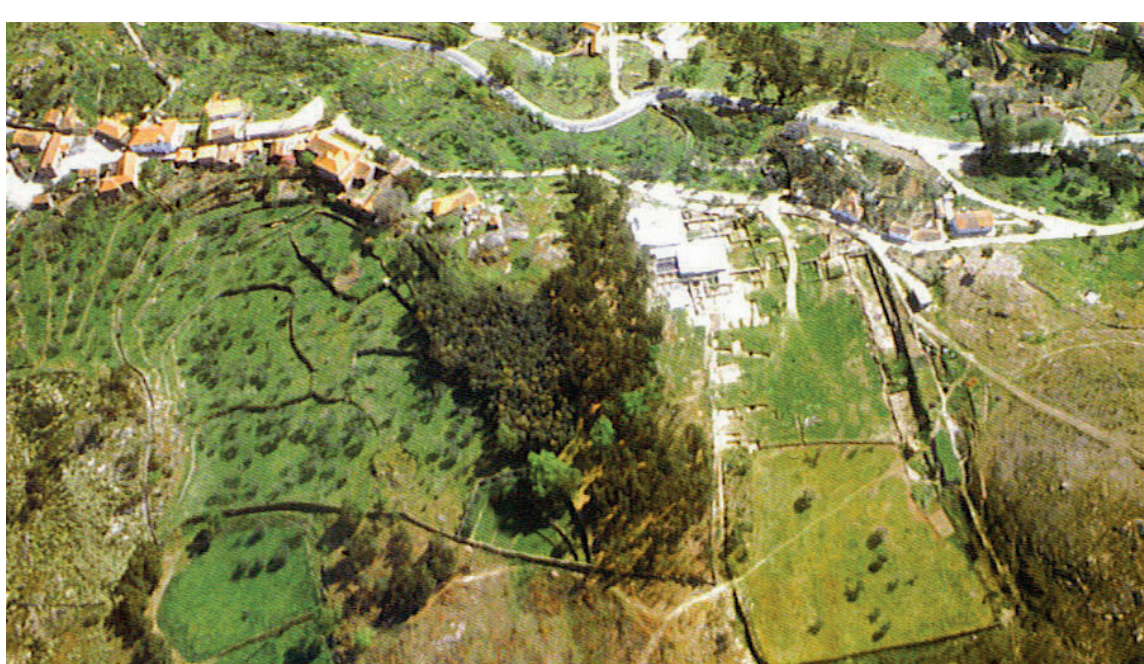

Fig. 160 - Espaço do centro cívico, foto-

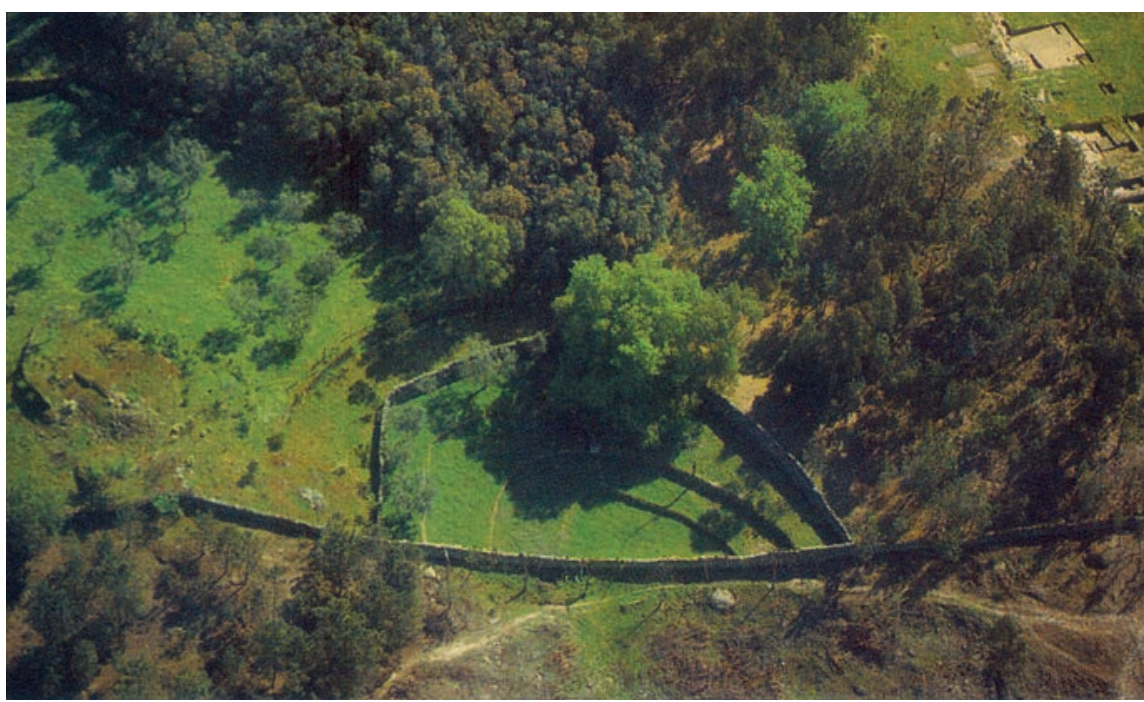

rafia aérea.
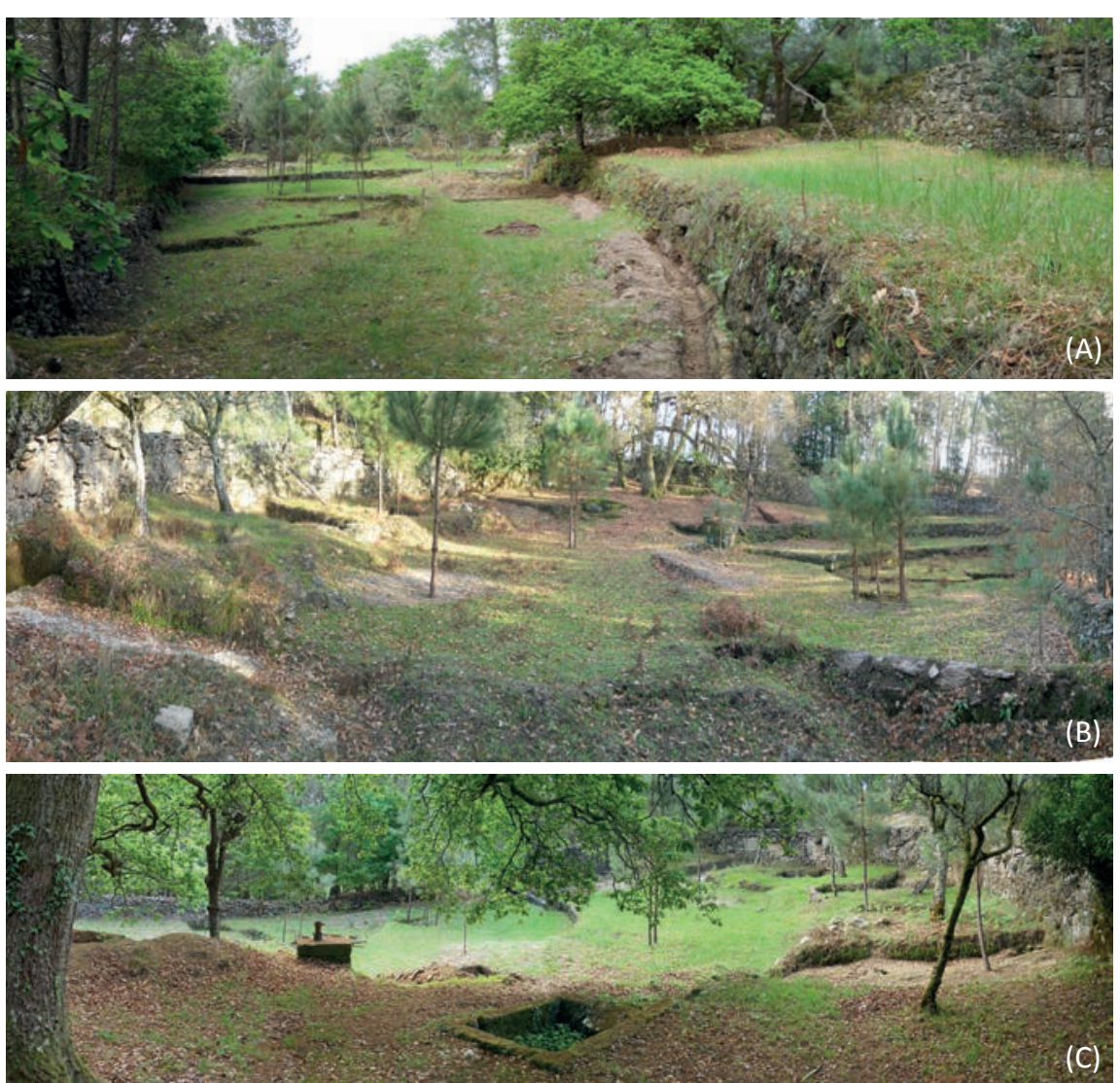

Fig. 162 - Teatro. Vistas panorâmicas.

(A) - no sentido nordeste.

(B) - no sentido sul.

(C) - no sentido norte. 


\subsection{2 - Traçado do Teatro}

Infelizmente, não foram muitos os vestígios que resistiriam ao tempo para nos dar uma ideia exacta do desenho e dimensão do teatro de Tongobriga. Se no forum já se considerava difícil perceber a organização do seu espaço, pela falta de elementos, no teatro essa tarefa é muito mais complicada.

Os vestígios existentes na área do teatro dividem-se entre os elementos actuais (um conjunto de socalcos ${ }^{2}$ que certamente reaproveitara material da antiga estrutura) e os elementos que surgiram nas sondagens realizadas (fig. 163).

Os elementos das sondagens correspondem apenas a afloramentos graníticos talhados, um preparo do terreno cujo objectivo foi drenagem da encosta. Para além destes foi descoberto um conjunto de drenos, composto por dois drenos de traçado curvilíneo e uma série de arranques que aparentam ser radiais (fig. 166). Um outro dreno deste conjunto afasta-se e sobe até uma cota mais elevada.

Em toda a área do teatro foram encontrados, pontualmente, afloramentos trabalhados, por forma a criar pendente e, noutros casos, a ficar plana (fig. 164). $\mathrm{O}$ afloramento com pendente poderá corresponder à inclinação da cavea, e o afloramento plano poder pertencer a uma secção do praecintio (corredor de distribuição na cavea

Na metade sul da área do teatro foram encontrados um série de talhes no afloramento rochoso, aparentemente paralelos ou possivelmente radiais. Estes são muito semelhantes aos talhes encontrados em certas áreas do forum.

A partir dos dados existentes, é difícil visualizar a presença deste equipamento em Tongobriga. 0 facto de estes terrenos não serem propriedade do Estado dificulta a realização de sondagen para a procura de mais elementos, assim como uma correcta preservação da área. Actualmente, este espaço encontra-se arborizado, o que representa várias limitações na interpelação e visualização de todo o conjunto (fig. 165).

2 Para além de ter atraído para a identificação desta área como a zona do teatro, a geometria destes socalcos é bastante suspeita, pois aparentam dispor-se de forma concêntrica, podendo corresponder à posição de antigos elementos da estruturas do teatro.
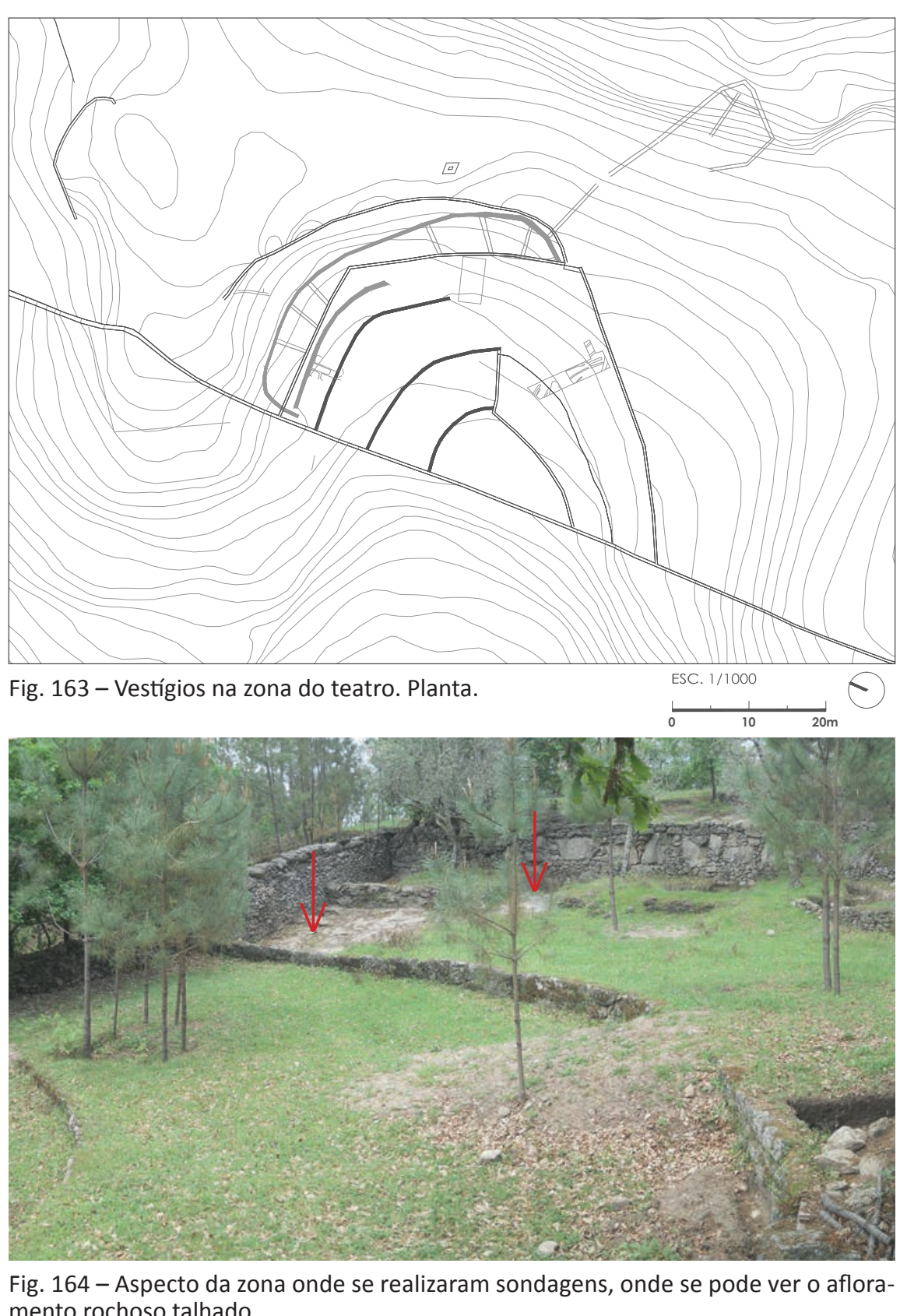
mento rochoso talhado.

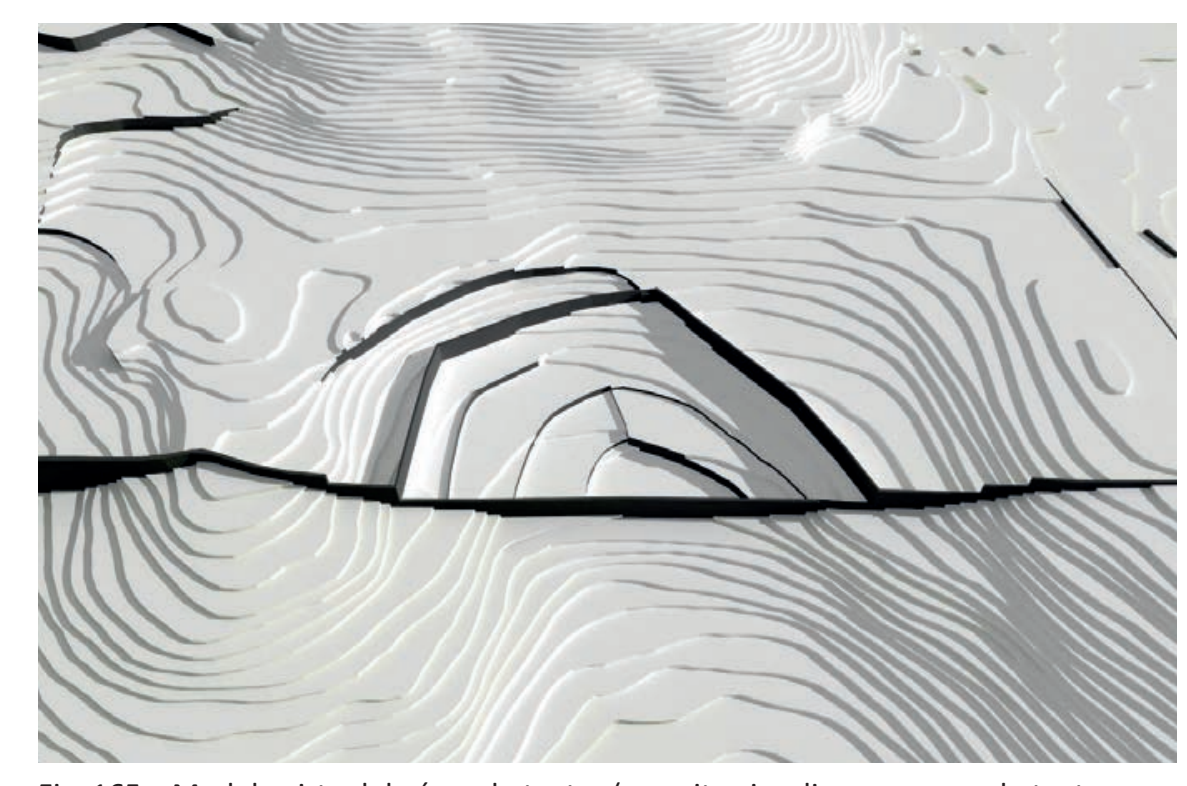

Fig. 166 - Vestígios arqueológicos.

(A) - Conjunto de drenos.
(B) - Imagem do dreno.

(B) - Imagem do dreno.
(C) - Perfil esboçado do dreno.
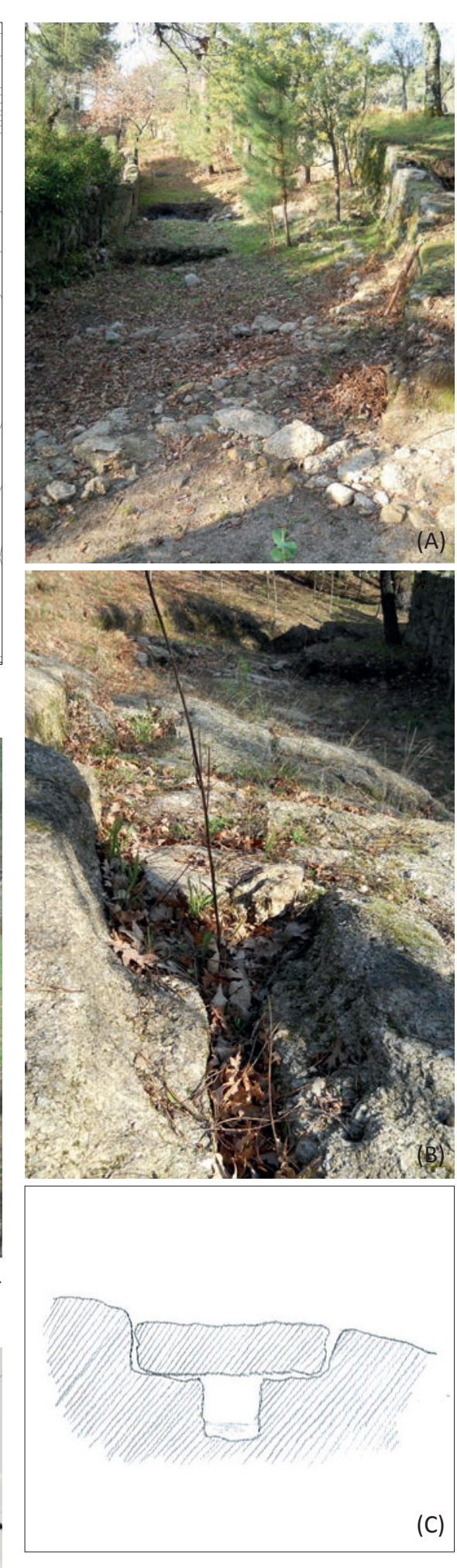

(C)
Fig. 165 - Modelo virtual da área do teatro (permite visualizar o espaço do teatro sem a arborização). 
Deste modo, também se torna difícil a aplicação dos preceitos de Vitrúvio, tendo em conta a falta de elementos existentes.

A partir da interpretação dos dados existentes, procurámos descobrir, no desencadear de vários passos, como seria o traçado deste equipamento:

- Na análise dos socalcos existentes, um dos muros distingue-se dos outros por aparentar uma curvatura de circunferência; muro este que terá levado a um cálculo de diâmetro de $52 \mathrm{~m}$, por Lino Tavares (fig. 167 A).

- Após as sondagens e o aparecimento dos drenos, nota-se, à partida, que estes nunca poderão ser concêntricos com o muro destacado. Portanto, a atenção vira-se para o conjunto, e assim a suspeita foca-se noutros muros, que aparentam ser concêntricos com os drenos (fig. 167 B).

- Para traçar uma hipótese de reconstituição da cavea, considerou-se com maior relevância uma série de muros, assim como os drenos que, aparentemente, se dispõem de forma concêntrica (fig. 167 B) e que se encontram na zona mais explorada do teatro.

- Numa primeira suposição, realiza-se uma experiência que se foca nos eixos correspondentes aos drenos radiais, com o objectivo de encontrar um ponto em comum e, assim, desvendar o centro do teatro. Mas tal exercício não oferece grandes resultados, mostrando-se possível que a disposição dos drenos não se relacione com o traçado do teatro (fig. 167 C).

- Numa segunda suposição, experimenta-se o traçado de arcos distintos (a partir de três pontos de cada muro), na expectativa de encontrar um centro comum, e embora não se tenha obtido um resultado claro, um dos centros aparenta ser o mais correcto. A este centro aparenta igualmente corresponder dois dos eixos dos drenos radiais (fig. 167 D).

- A partir do centro encontrado fazem-se traçar diferentes arcos de circunferência, com diferentes distâncias, e assim poderemos optar por aqueles que aparentam ter a proporção mais adequada, e correspondam aos vestígios existentes (fig. $167 \mathrm{E})$.

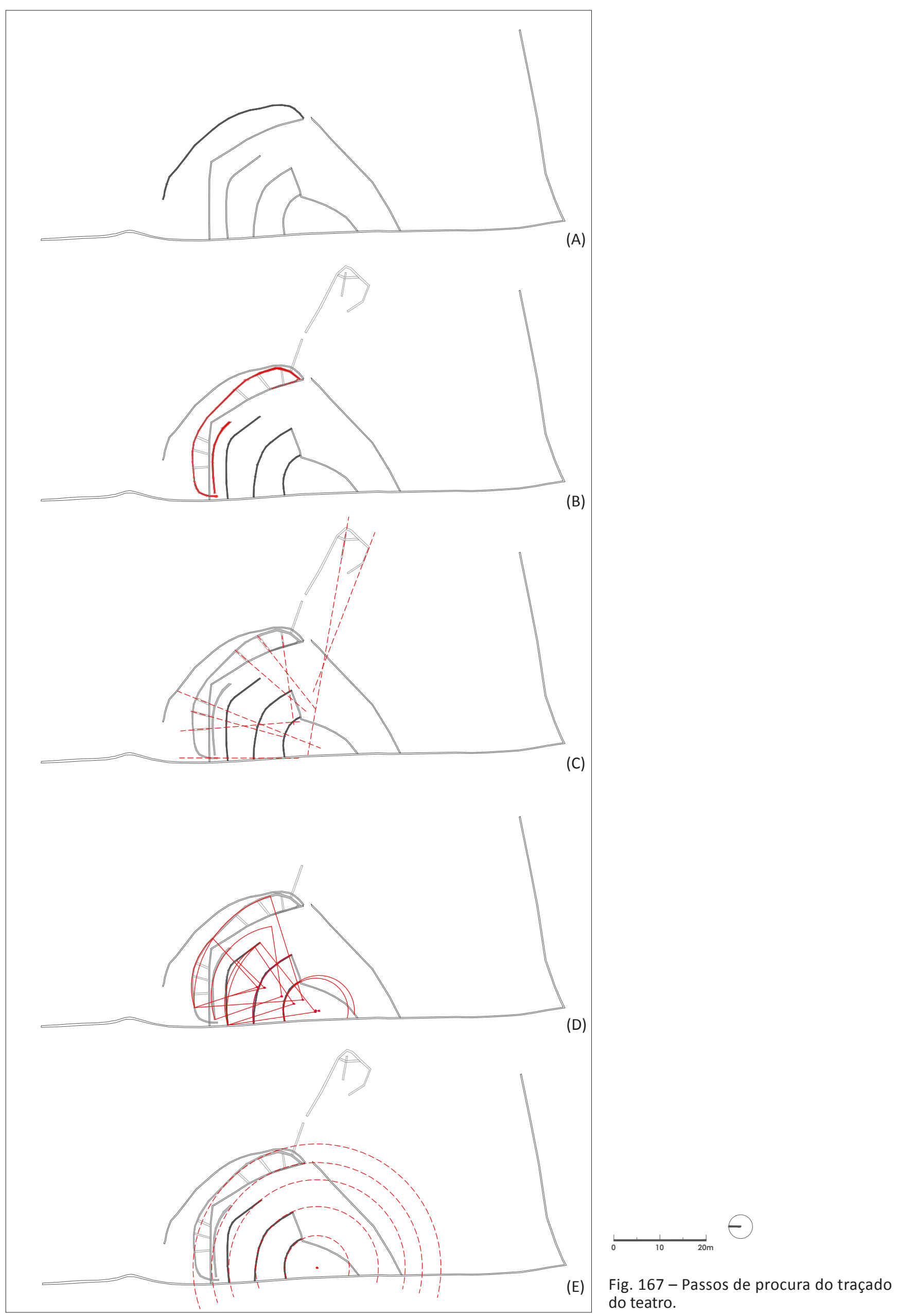

(E) Fig. 167 - Passos de procura do traçado
do teatro. 
- Não tendo definido um alinhamento para o corpo cénico, introduz-se agora a direcção dominante nos restantes equipamentos públicos e da cidade de Tongobriga (apoiada também na direç̧ão da quadricula actus) de $24^{\circ}$ a norte (fig. 168 A). Com a introdução deste dado, há um muro de suporte que chama a atenção, ao aparentar fazer $90^{\circ}$ com a orientação traçada. Este dado vem fornecer-nos um eixo de simetria para a composição do teatro (fig. $168 \mathrm{~A}$ ).

- Dos eixos correspondentes aos drenos radiais, traçados anteriormente, um deles aponta ao centro encontrado e aparenta fazer a divisão da cavea em $45^{\circ}$, o que poderá quere dizer que a cavea seria dividida em quatro (à semelhança do Teatro de Clunia).

- Ao fixar o esquema sobre uma grelha de modelação passus (modelação do centro cívico), efectuam-se alguns ajustes aos diâmetros dos arcos que elegemos anteriormente. E, assim os arcos passam a corresponder à mesma modelação que os restantes equipamentos públicos (fig. 168 B).

- Por uma questão de equilíbrio e pelas sondagens terem detectado um trabalho de afloramento num plano inclinado, junto ao último arco, optou-se por traçar mais um arco, com a mesma distância que os anteriores (cinco passus). Desta forma, aparenta englobar uma secção de muro nesse arco (fig. 168 C).

Desta forma chega-se a um esquema de traçado para o Teatro de Tongobriga que servirá de comparação e de objecto de ensaios, para o seu enquadramento e posição.

O esquema proposto para o teatro divide-se em duas hipóteses de diâmetro: uma hipótese em que o teatro de Tongobriga teria cerca de $68 \mathrm{~m}$ de diâmetro; e outra em que teria cerca de $82 \mathrm{~m}$.

Esta dúvida reside no último arco traçado, pois, embora este corresponda a uma pendente no afloramento, é possível que se tratasse de uma rua em torno da cavea (fig. 169).

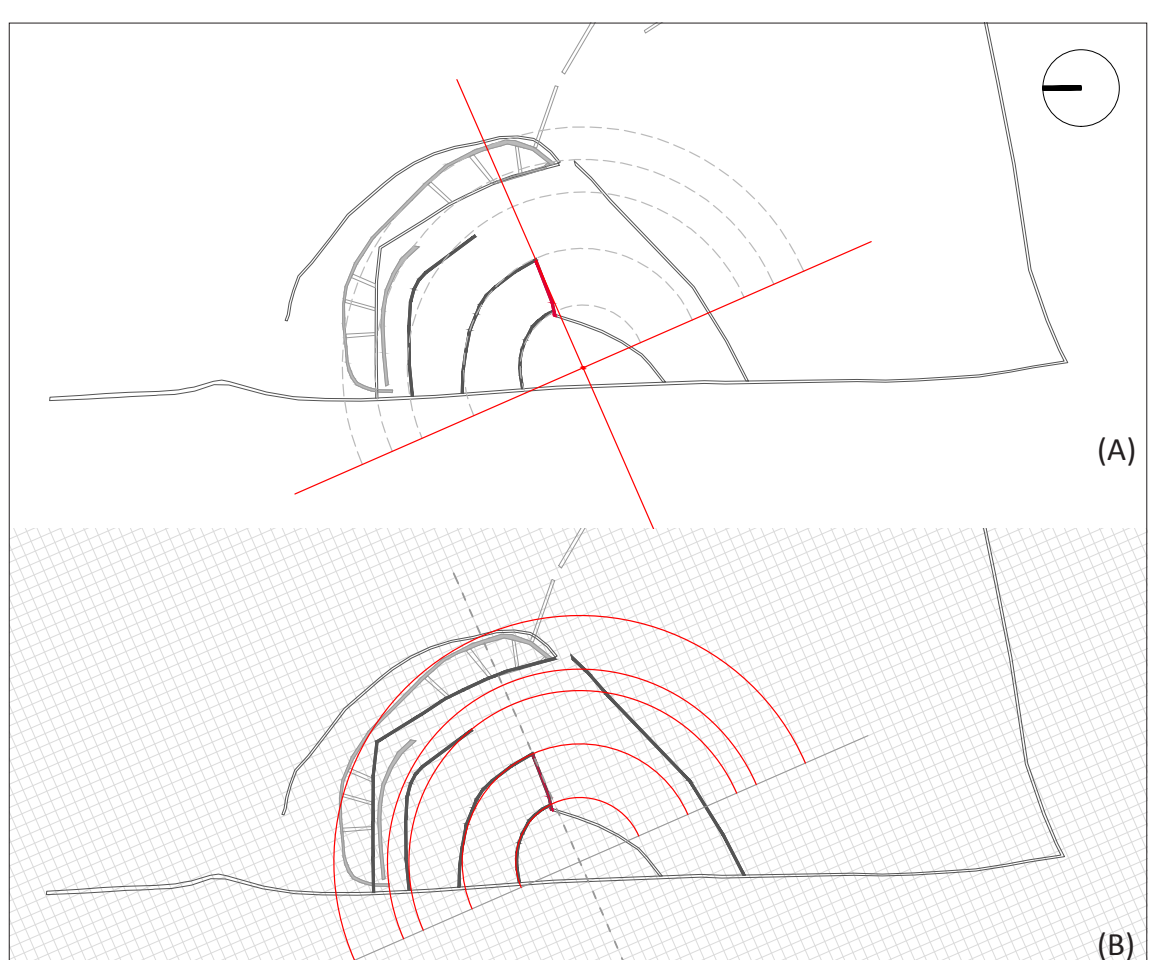

(B)

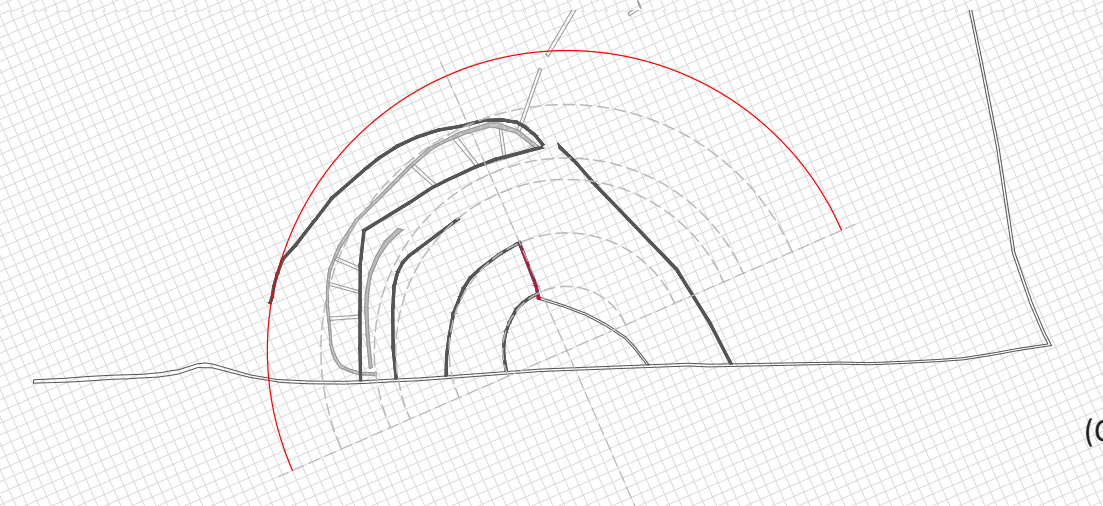

g. 168 - Passos de procura do traçado do teatro (continuação).

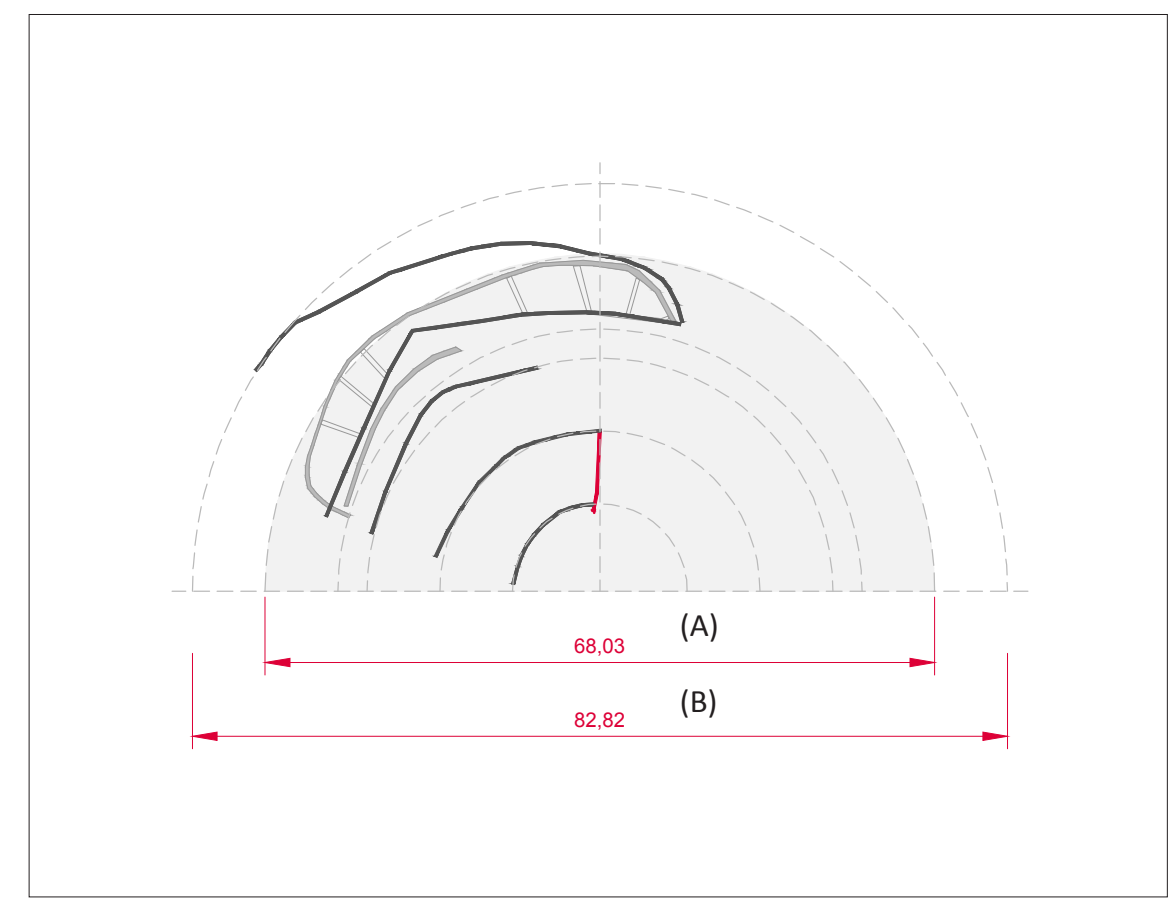
0

Fig. 169 - Traça proposto para o Teatro de Tongobrig

(A) - Hipótese 1. Diâmetro: 82,8 metros. 


\subsection{3 - Comparação geral}

No exercício de comparação do traçado proposto para o teatro de Tongobriga com outros teatros, os dois diâmetros apontados chamam a atenção de diferentes teatros (fig. 170).

Quando procuramos teatros cujas dimensões do diâmetro da cavea sejam próximas a 82 metros, os casos que se aproximam mais são os teatros de Mérida $(79,2 \mathrm{~m})$, Sagunto $(84,6 \mathrm{~m})$, Óstia $(87 \mathrm{~m})$, Clúnia $(90 \mathrm{~m})$ e Lepis Magna $(87 \mathrm{~m})$. De entre estes, quando se repara na divisão vertical da cavea, destacam-se o caso de Óstia, Sagunto e Mérida.

No que diz respeito ao diâmetro de 68 metros, o teatro que mais se aproxima é o de Bracara Augusta $(68,6 \mathrm{~m})$.

De entre estes, o caso do teatro de Bracara Augusta é o que se destaca mais; pois, em termos de dimensão e divisão da cavea, bem como de orientação, equipara-se à situação de Tongobriga.

\subsection{4 - Integração da cavea no terreno}

Ao situar o traçado do teatro no terreno, denotam-se duas situações que comprovam o seu posicionamento.

A primeira indica-nos, pela análise da morfologia do terreno, que a cavea se enquadra perfeitamente na curvatura da encosta do terreno. $O$ traçado adapta-se muito bem às curvas de nível. A segunda situação é a forma como o terreno, ainda hoje, se encontra preparado de modo a permitir o acesso ao espaço do teatro. Se analisarmos figura da planta e a imagem da maqueta virtual, onde se encontra altimetricamente bem realçada, é possível perceber que há uma zona de cota constante em todo o redor da cavea; principalmente voltada para nascente e sul (zona entre o teatro e forum) (fig. 171 e 172).

Neste sentido (juntando o enquadramento a nível do centro cívico e da cidade), a partir do quadriculado actus manifesta-se um situação curiosa. O traçado deste ocupa seis unidades actus quadratus ( $3 \times 2$ ), em que o seu eixo de simetria coincide com a metade do actus central. Se considerarmos a possibilidade de um porticus postscaena, alinhado pelo fundo do forum, todo o conjunto ocuparia nove unidades do quadriculado ( $3 \times 3$ unidades actus quadractus) (fig. 173).

Um caso muito semelhante, com esta mesma característica de implantação, é o teatro de Bracara Augusta; pois, quando visto o teatro,

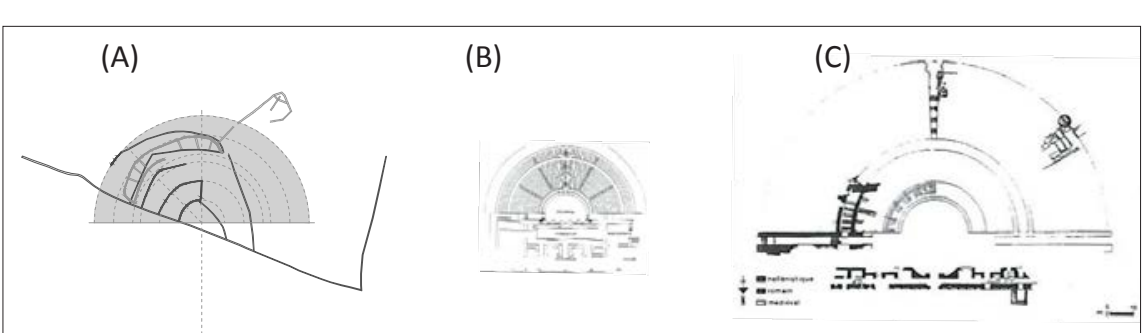

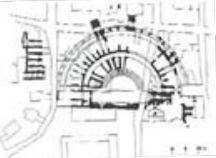
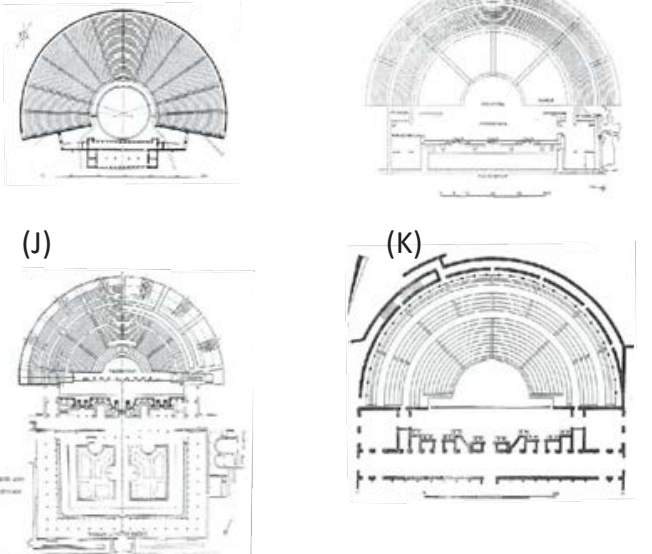

(M)

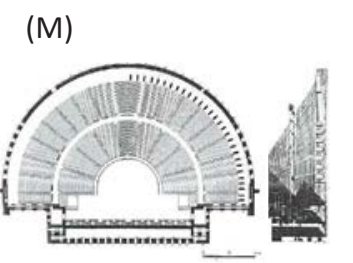

(N)

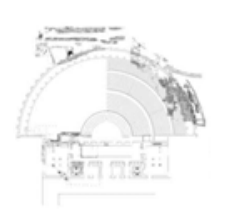

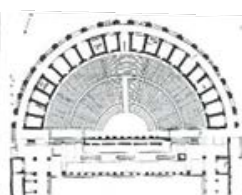
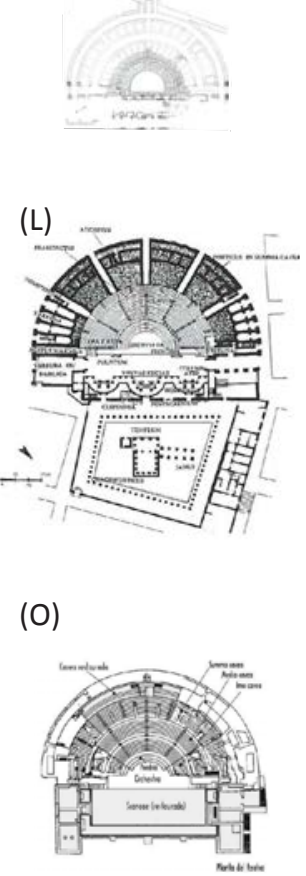

Fig. 170 - Teatros a mesma escala.

(A) - Teatro de Tongobrigo C) - Teatro de Acinipo. (D) - Teatro de Naples. (E) - Teatro de Cartagena. (F) - Teatro de Ostria. (H) - Teatro de Clúnia. - Teatro de Saepium. (J) - Teatro de Mérida. K) - Teatro de Orange. (M) - Teatro de Aspendos. (N) - Teatro de Bracara Augusta. O) - Teatro de Sagunto.
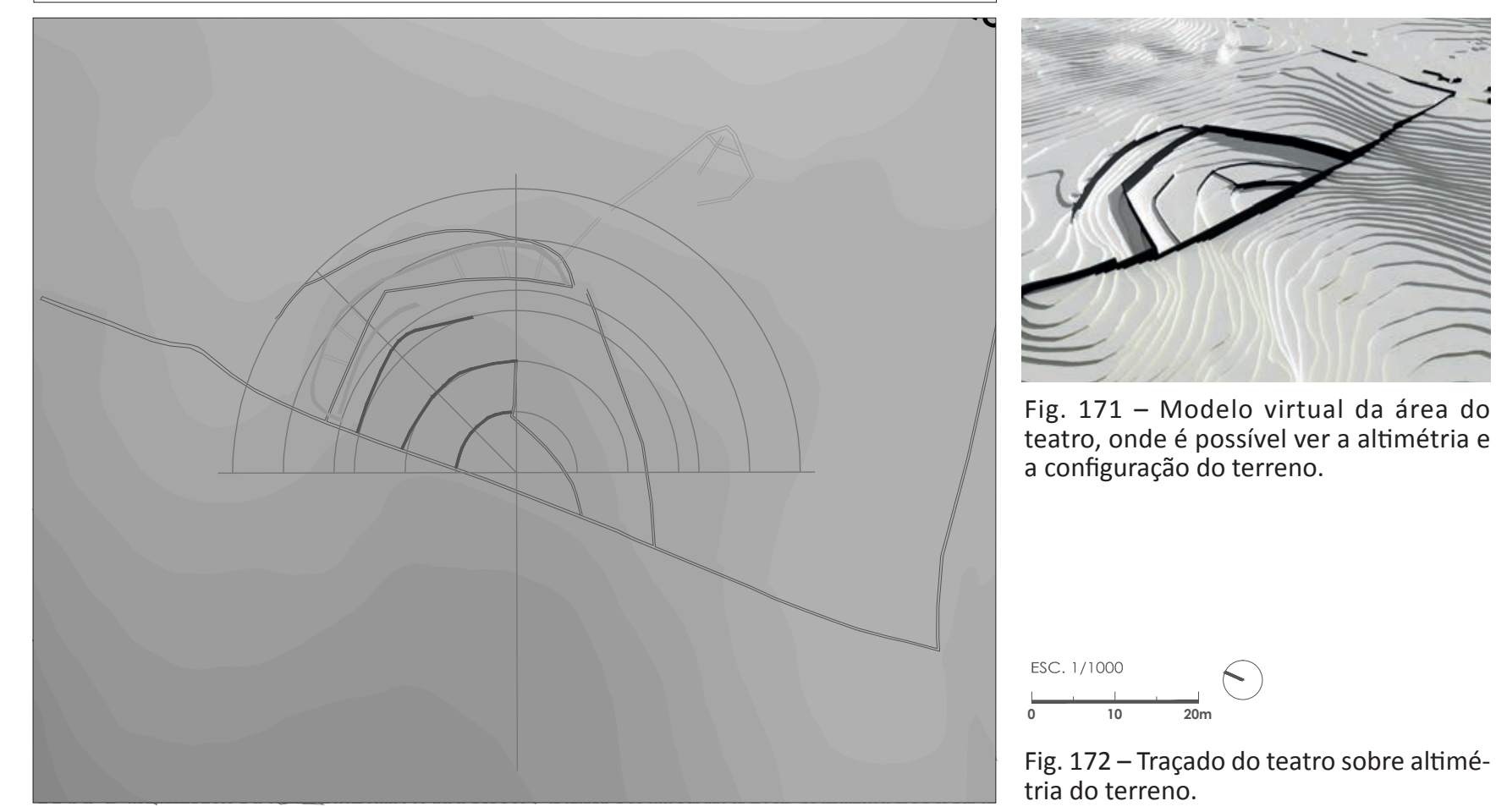
ig. 171 - Modelo virtual da área do configuração do terreno.

ESC. $1 / 1000$ Fig. 172 - Traçado do teatro sobre altiméa do terreno. 
enquadrado pela grelha da cidade de Bracara, ocupa também um quadrado de três por três unidades actus. $O$ caso de Bracara torna-se ainda mais evidente, pois partilha uma das suas unidades com as termas. As termas não chegam a ocupar a totalidade de uma quadrícula, porque a palestra da mesma adapta-se à curvatura da cavea. Em conjunto, este dois equipamentos confirmam este tipo de implantação para o teatro (fig. 174)

Voltando à analise da preparação do terreno, em combinação com o quadriculado, denota-se outro dado particular. A nordeste da zona do teatro situa-se um muro de suporte, que sustém o terreno a uma cota um pouco mais elevada que a cota dominante (fig. $173 \mathrm{~A}$ ). Esta estrutura tem uma configuração do tipo abside, e uma zona de enchimento em cascalho; o que sugere a possibilidade deste elemento ter sido uma estrutura romana. Quando vista no âmbito do quadri culado, situa-se no limite da quadrícula. Agora, curiosamente, numa posição simétrica ao eixo do teatro, está em relação com esta estrutura uma área rasgada na encosta, que se encontra ao mesmo níve da outra (fig. 173 B). Isto confirma a preparação do terreno em torno da cavea, assim como a própria posição do eixo de simetria da estrutura do teatro (fig. 176).

Em comparação com outros teatros, repara-se no exemplo do teatro de Óstia, onde também se verifica a existência de duas estruturas similares às encontradas em Tongobriga. Essas estruturas aparentam ter a função urbanística de preenchimento do espaço deixado pela implantação do teatro na quadrícula (fig. 175). Como em Óstia, o diâmetro do teatro corresponde à largura do quarteirão, e estas estruturas encontram-se mais próximas da cavea. No caso de Tongobriga, como o diâmetro do teatro não chega a ocupar a largura das três unidades, essas estruturas encontram-se mais afastadas. No entanto, aparenta tratar-se da mesma situação; um pouco como em Bracara, em que as termas fazem o ajuste à malha da cidade.

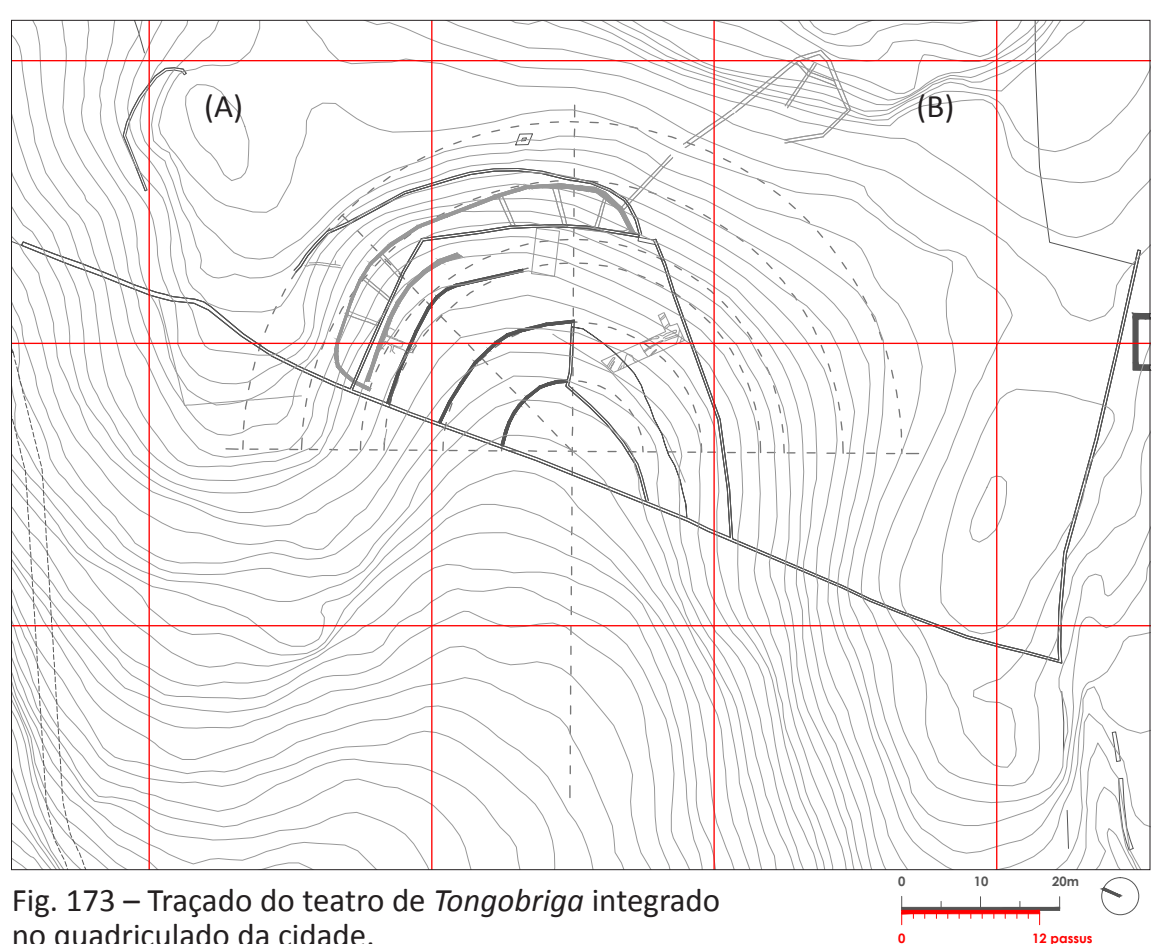

no quadriculado da cidade.
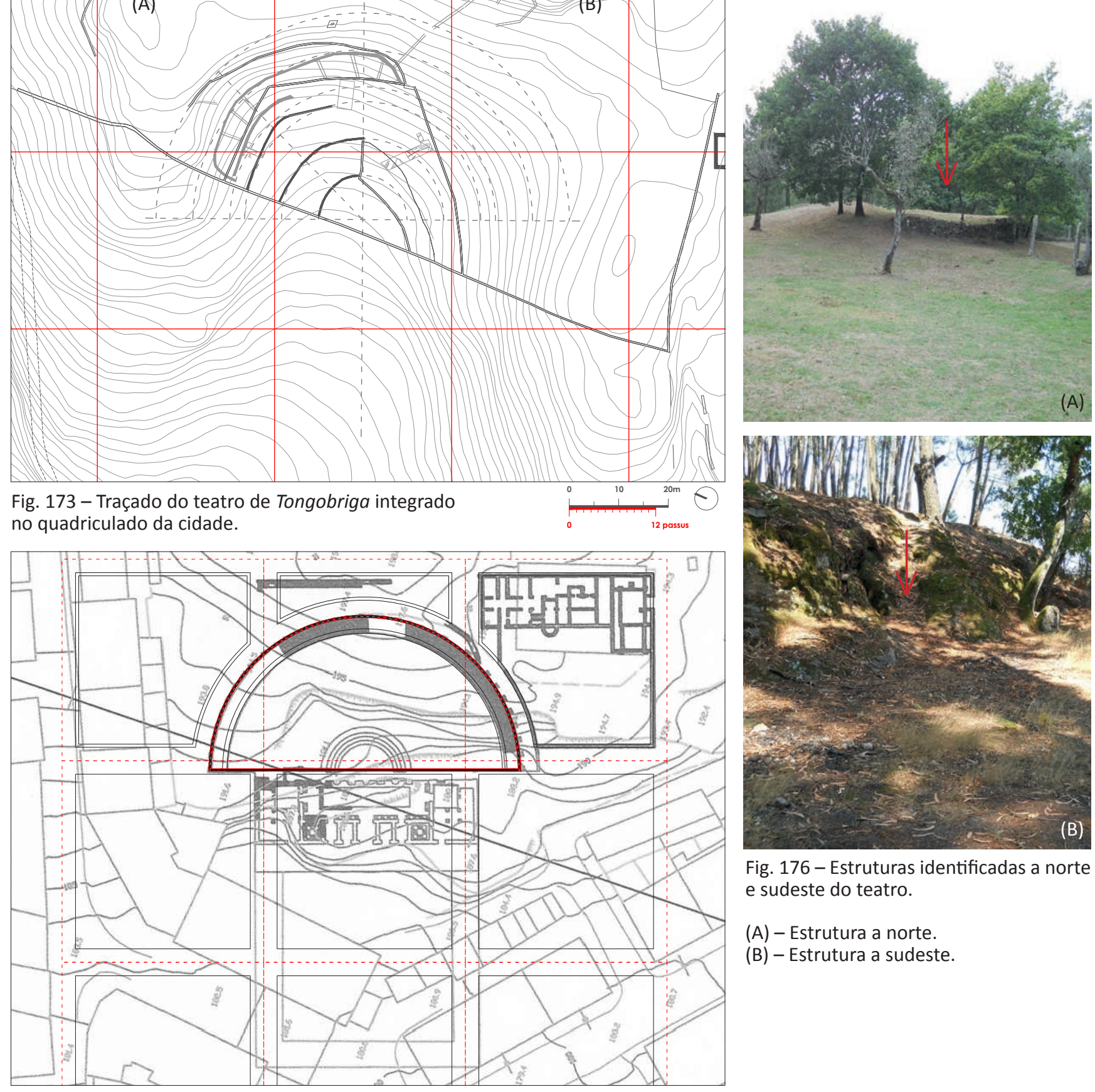

Fig. 176 - Estruturas id
e sudeste do teatro.

(A) - Estrutura a norte.
(B) - Estrutura a sudeste.

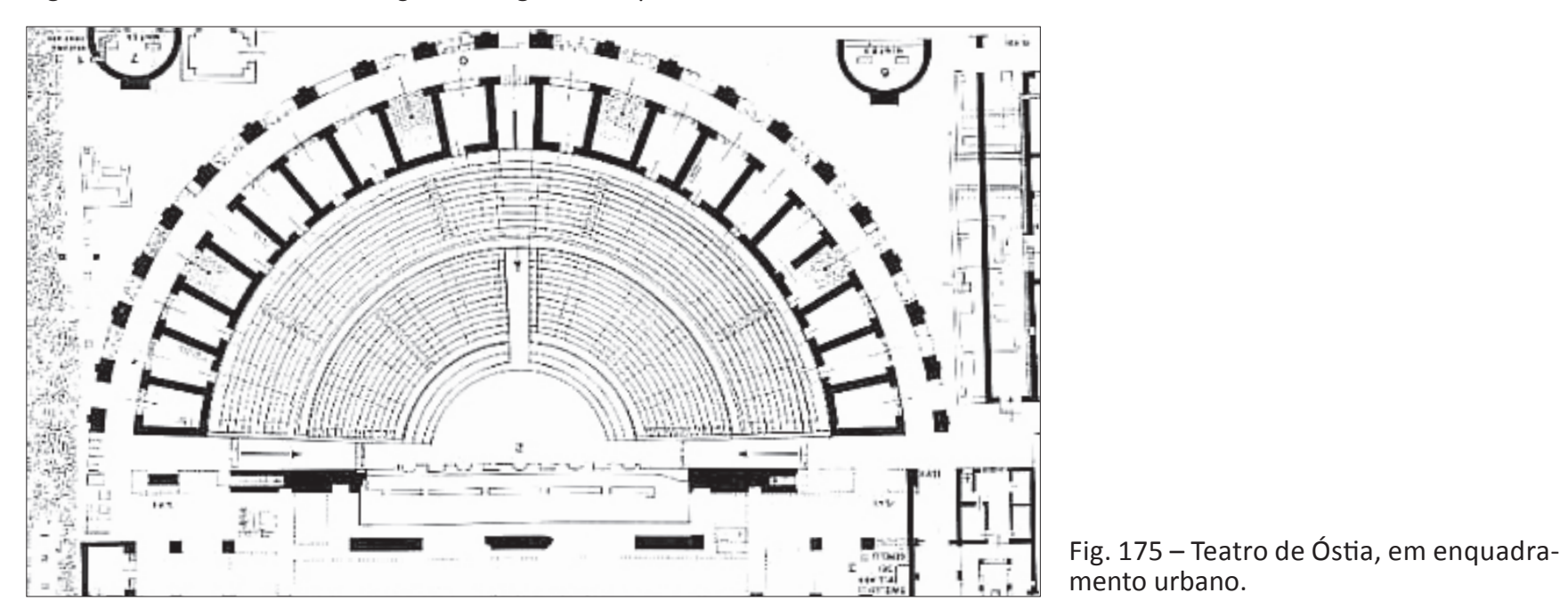




\subsection{5 - Comparação com Bracara Augusta}

Quando se compara a cidade de Tongobriga com Bracara Augusta, muitas são as semelhanças: a orientação, a organização segundo a quadrícula, entre outras. Quando se trata da comparação entre os seus teatros, o mesmo acontece. Ambos se orientam a sudoeste, e ambos se enquadram num espaço correspondente a nove quadrículas (3x3), onde o seu eixo de simetria se encontra a eixo com a quadrícula central. Daí parecer importante uma comparação mais atenta.

Ao sobrepor a planta de reconstituição do Teatro de Bracara Augusta sobre a proposta de traçado para o teatro de Tongobriga manifestam-se algumas coincidências (figs. 177 e 178).

É possível observar que a proposta de subdivisão da cavea (realizada anteriormente) é muito semelhante ao teatro de Bracara. São de realçar: o eixo que é coincidente com o murete (balteus) que separa os degraus da proedria com o preacintio, e o eixo coincident com o limite da cavea de Bracara (fig. 178 A). Mas as restantes semeIhanças não são menos relevantes.

O esquema de traçado seguia uma sequência numeral de passus em $6+5+5+2+5+5^{3}$, onde se propunha apenas um praecintio com dois passus de largura numa zona onde foi encontrado o talhe de afloramento plano, e que a ima e media cavea fossem juntas (fig. 178 B).

Comparados os dois teatros, o esquema para o teatro de Ton gobriga poderia ser $6+1+5+1+5+1+5+5^{4}$. Uma proposta que não invalida nada do que até aqui foi referido e que se baseia no teatro da cidade mais próxima de Tongobriga, tornando-a mais credível.

Em corte, o espaço arranjado para o teatro de Tongobrig não dispõe de uma pendente muito acentuada, variando apenas entre os $13^{\circ}$ e $18^{\circ}$ (fig. 179). Ao observar a pendente de outros teatros, podemos concluir que não se verificam pendentes inferiores a 23-25 (fig. 180) $)^{5}$.

Desta forma, na situação de Tongobriga, podemos presumir que os drenos encontrados, assim como as pendentes do afloramento, são apenas decorrentes da preparação do terreno (drenagem de terreno), da pré-construção de estruturas que suportariam a inclinação da cavea.

${ }^{3}(6)$ orchestra + (5) ima cavea + (5) media cavea + (2) praecintio + (5) summa cavea $+(5)$ rua?

orchestra + (1) praecintio + (5) ima cavea + (1) praecintio + (5) media cavea + (1) (5) Porticus summa cavea, rua ou nada.

a partir de levantamentos de Lara Salvador, em: El teatro romano de sagunto: génisis y construcción, 1991, p. 206.

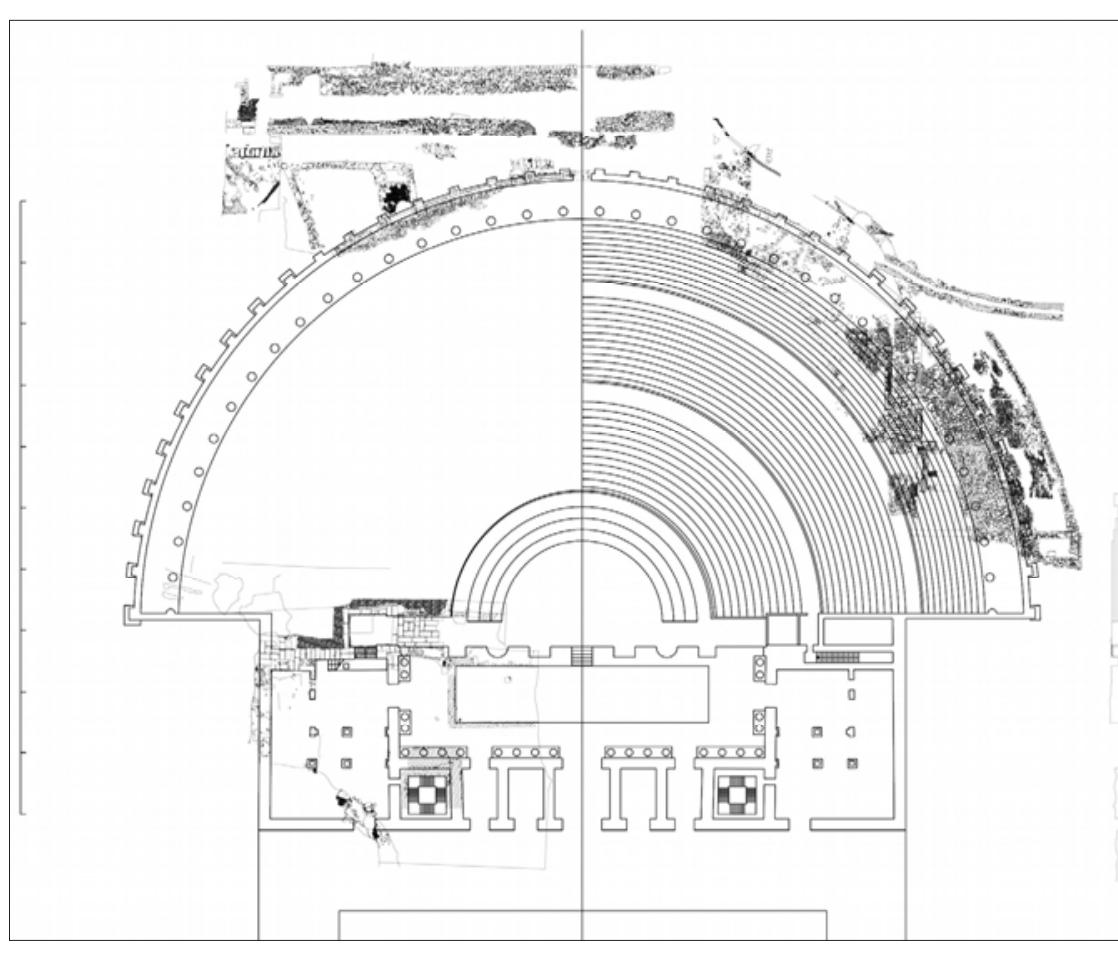

Fig. 177 - Hipótese de traçado para o Teatro de Bracara Augusta, por Ricardo Mar.

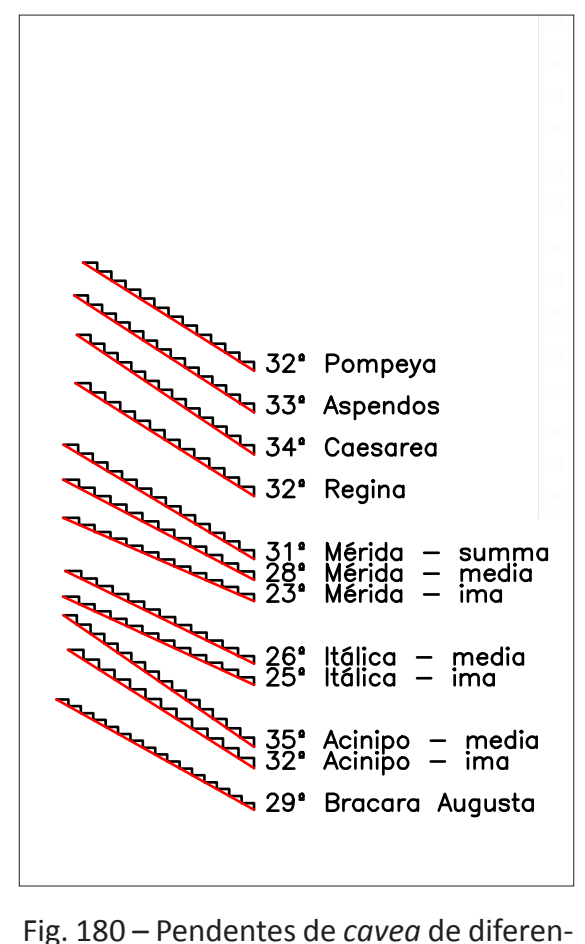

tes teatros.

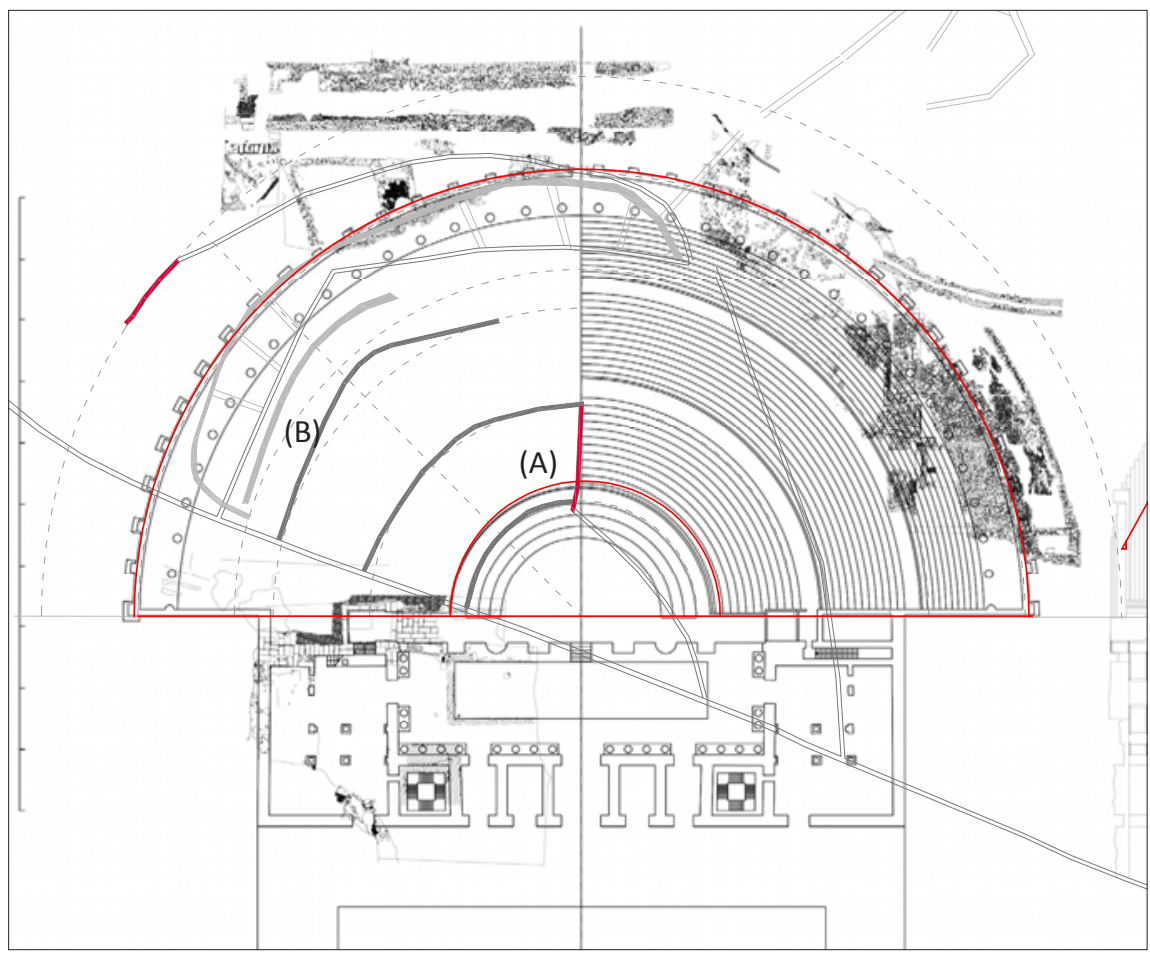

Fig. 178 - Sobreposição do traçado do Teatro de Tongobriga e de Bracara Augusta.
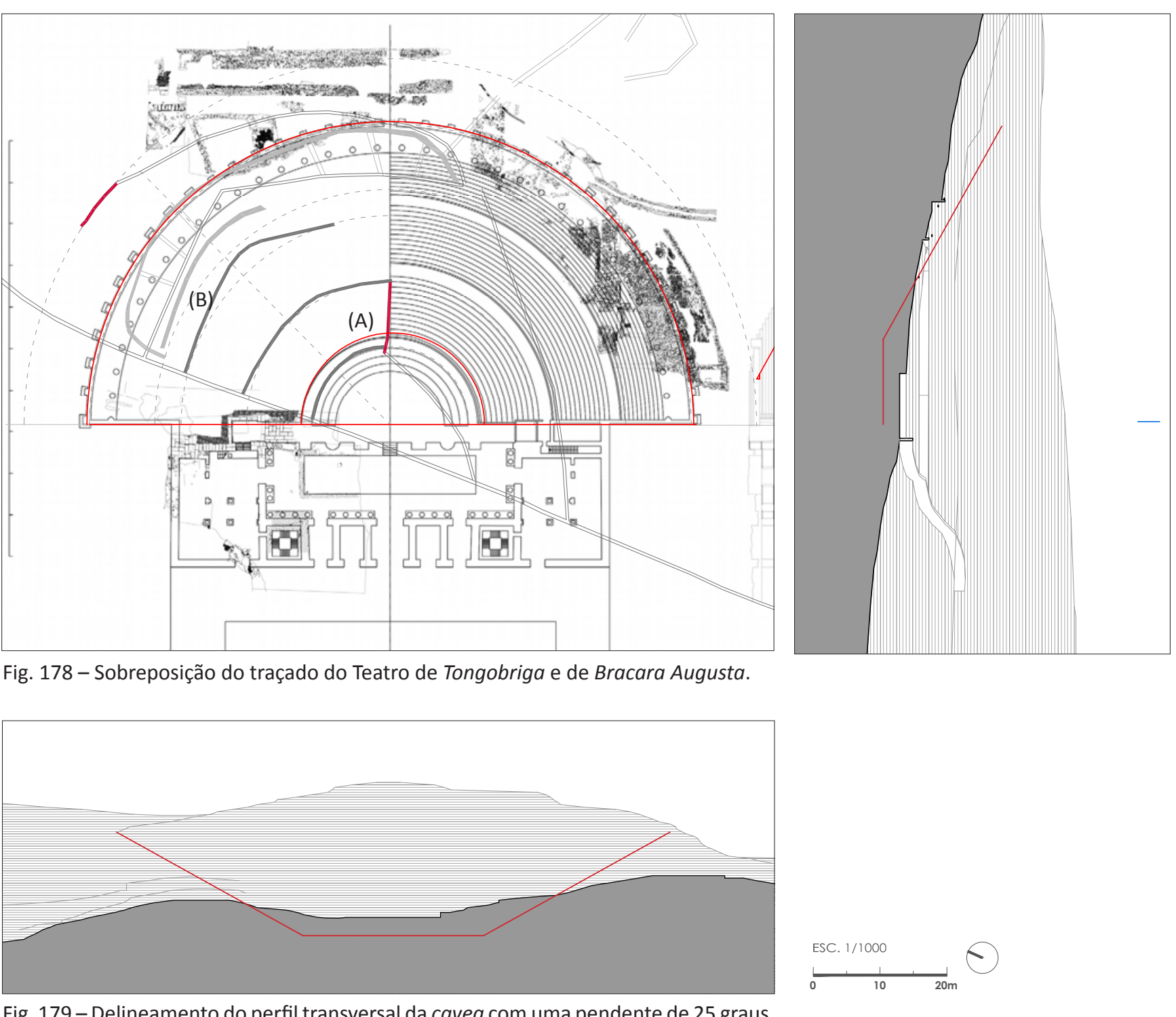

Fig. 179 - Delineamento do perfil transversal da cavea com uma pendente de 25 graus. 

cavea, toma-se em consideração a posição dos afloramentos graníticos a descoberto. A partir do que se encontrar na cota mais baixa faz-se traçar uma linha com $23-25^{\circ}$, obtendo, desta forma, a posição da cavea. Tal leva à possibilidade de construção do limite de cavea em duas ordens; o que conduz a que o acesso à cavea fosse feito através dos vomitoria, até chegar ao praecintio que dividia a summa e media cavea.

Assim, volta-se à comparação com Bracara, usando o corte do seu teatro como objecto de confrontação e ensaio. Ao sobrepor o perfil do teatro no perfil do terreno de Tongobriga, toma-se igualmente em linha de conta os locais onde se encontra o afloramento como base de apoio (figs. $181 \mathrm{e} 182$ ).

O espaço que resulta da diferença entre a pendente do afloramento e a pendente da cavea poderá, por um lado, ter sido apenas um espaço de enchimento, mas, por outro, sido também um espaço que terá dado lugar a um sistema de acessos à cavea. Um sistema que terá servido para a repartição de acessos pelas diferentes cavea (ima, media e summa), visto estes serem destinados a diferentes estratos sociais. Desta forma, parece-nos pertinente supor como tal sistema funcionaria (fig. 183).

Assim, na sequência da hipótese de o acesso à media cavea ser realizado por vomitoria, que se encontravam de cota com o terreno envolvente, a partir da mesma cota, supomos que se teria acesso a diferentes escadas para aceder à summa cavea (ta) como acontece em teatros como Mérida e Óstia [rever fig. 170]). Para aceder à orquestra, não haverá dúvida que o acesso seria feito pelos aditus (lateralmente ao teatro, entre a cavea e corpo cénico scaena). Faltaria, portanto, perceber como se realizava o acesso ima cavea.

Para se realizar o acesso à ima cavea, pensamos que terá existido um corredor de circulação horizontal entre as duas pendentes. Este estaria assente num afloramento plano, que até certo ponto julgávamos ser o praecintio; mas a partir do momento em que a pendente (do preparo do terreno) não corresponde à cavea, parece-nos lógico que estivesse antes destinado a uma circulação sob a cavea (fig. 182 B).

A este raciocínio podemos associar uns cortes que se encontram no terreno, e para os quais se desconhece a função. É possível que se tratasse do acesso a esta circulação.
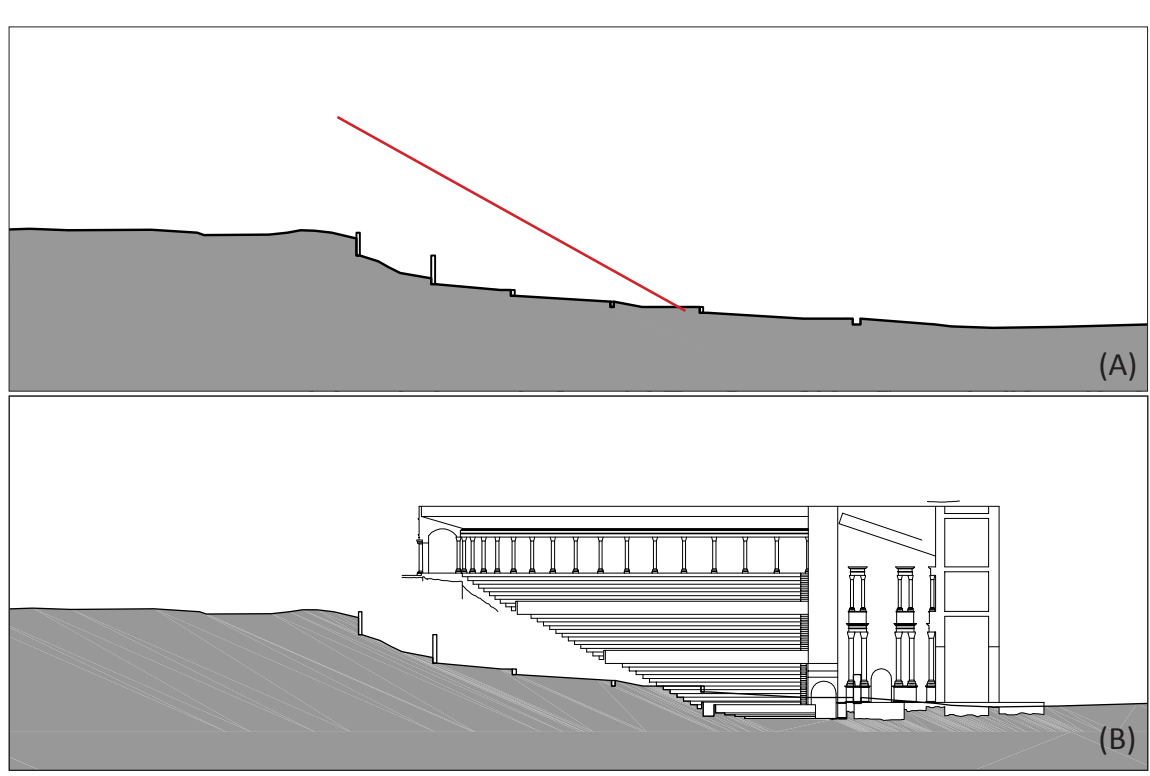
Fig. 181 - Aplicação do corte de Bracara
Augusta no caso de Tongobriga. Perfil do

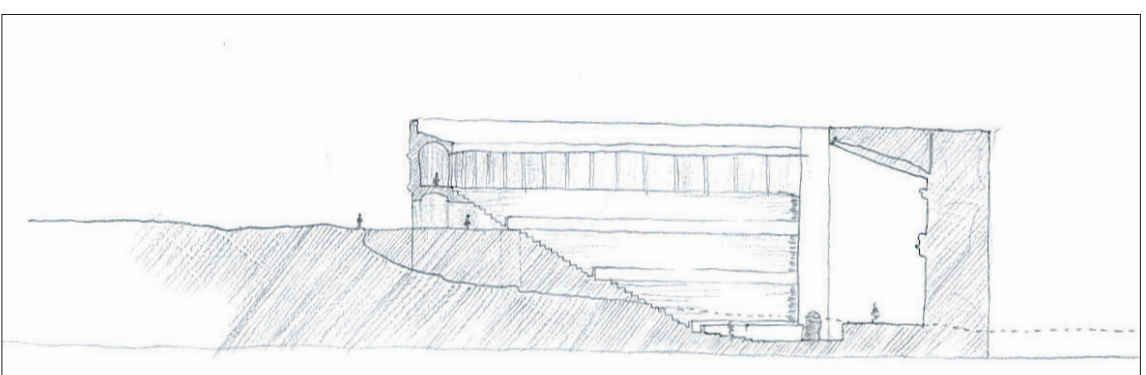

(A)

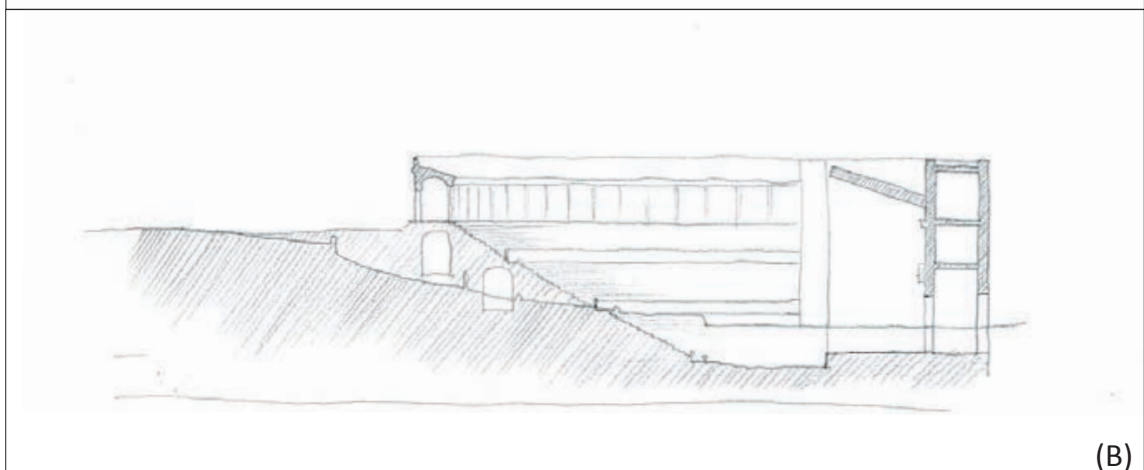

Fig. 182 - Hipóteses do limite de cavea.
Com duas ordens (A). Com uma ordem (B).

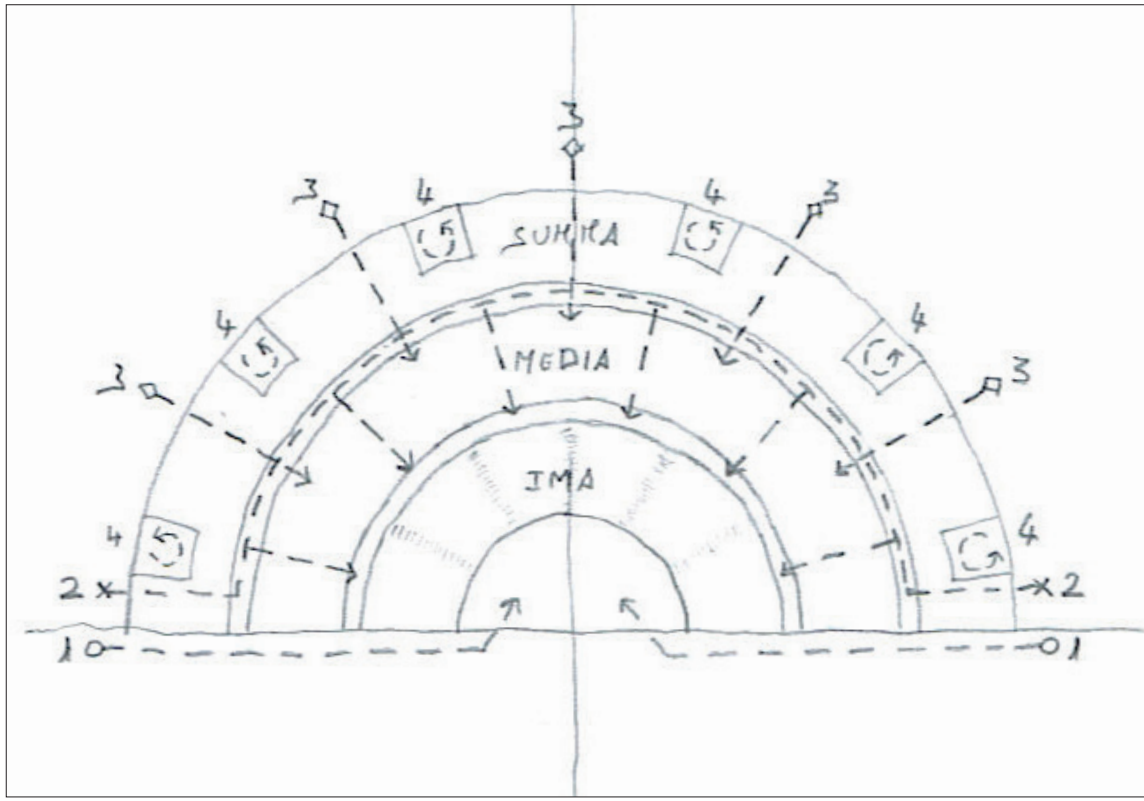

Fig. 183-Hipotese do limite de cavea com duas ordens.

(1) - Acesso à orquestra.

(3) - Acesso à media cave

4) - Acesso à summa cavea 

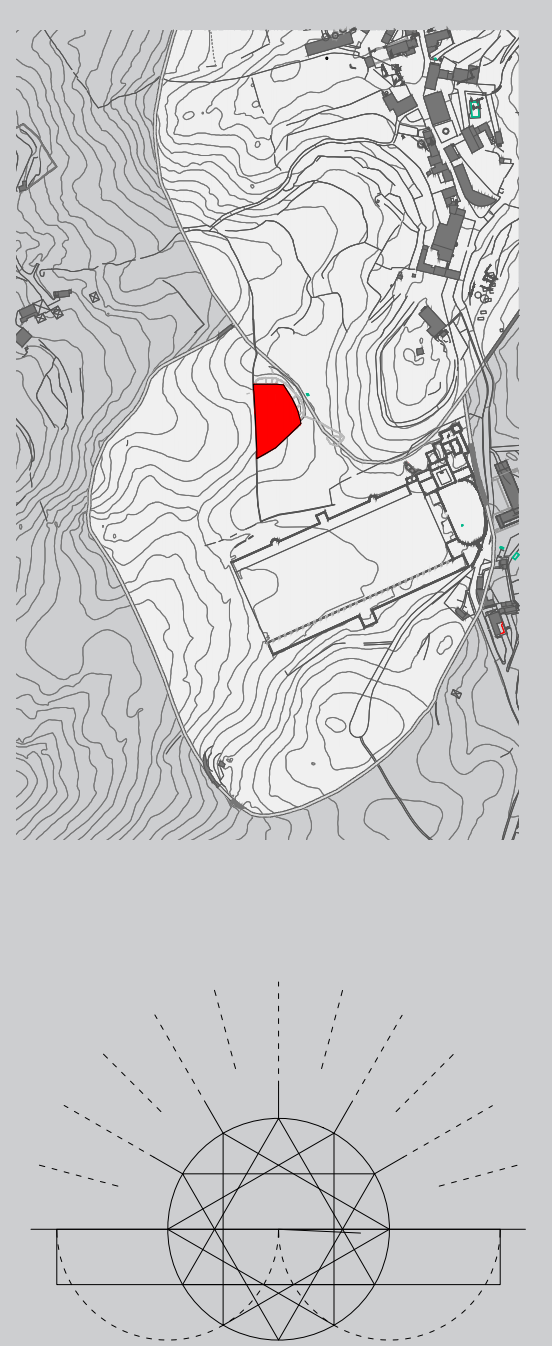

Fig. 184 - Traçado de Vitrúvio

\subsection{6 - Vitrúvio no Teatro de Tongobriga}

Em todos os estudos que buscam um esquema tipológico regulador para o teatro romano, o quinto livro do tratado de Vitrúvio é sempre a base da pesquisa, seja para se suportar nele ou para o contradizer.

No caso do teatro de Tongobriga, apesar de este não ser do período Augustano, são curiosas algumas das relações proporcionais que se verificam, quando se aplica tal conjunto de preceitos. Assim, a aplicação do traçado vitruviano no Teatro de Tongobriga pode resultar numa ferramenta muito útil para definir algumas relações geométricas, e colocar hipóteses acerca de elementos não presentes (figs. 184 e 185).

Os passos para o traçado vitrúviano de um teatro são os seguintes:

- Traça-se uma circunferência completa da orquestra (orchestra) sobre um lugar plano ${ }^{6}$. 0 diâmetro da circunferência não vem especificado, é elegido pelo arquitecto.

- No seu interior inscrevem-se quatro triângulos equiláteros ${ }^{7}$.

- A base do triângulo que ficar paralela ao corpo cénico e mais próxima dela define o alinhamento da frente cénica (sceanae frons $)^{8}$.

- Uma paralela à frente desta linha divide o estrado (pulpitum) do proscénio (proscaenium) e delimita o espaço da orquestra no interior da curvatura da cavea ${ }^{9}$.

- Os sete ângulos em contacto com o semicírculo da cavea determinam as suas subidas e escadarias (scalae) do primeiro circulo ${ }^{10}$. Os tramos superiores alternam-se com os de baixo.

- Os outros cinco ângulos assinalam a composição do corpo cénico; em frente da central, situa-se a porta régia (valva regia) e as portas dos hóspedes (valuae hospitaliorum), uma de cada lado.

- A parte alta da bancada estará nivelada com a altura do edifício cénico ${ }^{11}$.

$$
\begin{aligned}
& { }^{6} \text { Vitrúvio } V, 6,1 . \\
& 7 \text { Vitrúvio } V, 6,1 . \\
& 8 \text { Vitrúvio } V, 6,1 . \\
& { }^{9} \text { Vitrúvio } V, 6,1 . \\
& { }^{10} \text { Vitrúvio } V, 6,3 .
\end{aligned}
$$$$
{ }^{11} \text { Vitrúvio } V, 6,4 \text {. }
$$

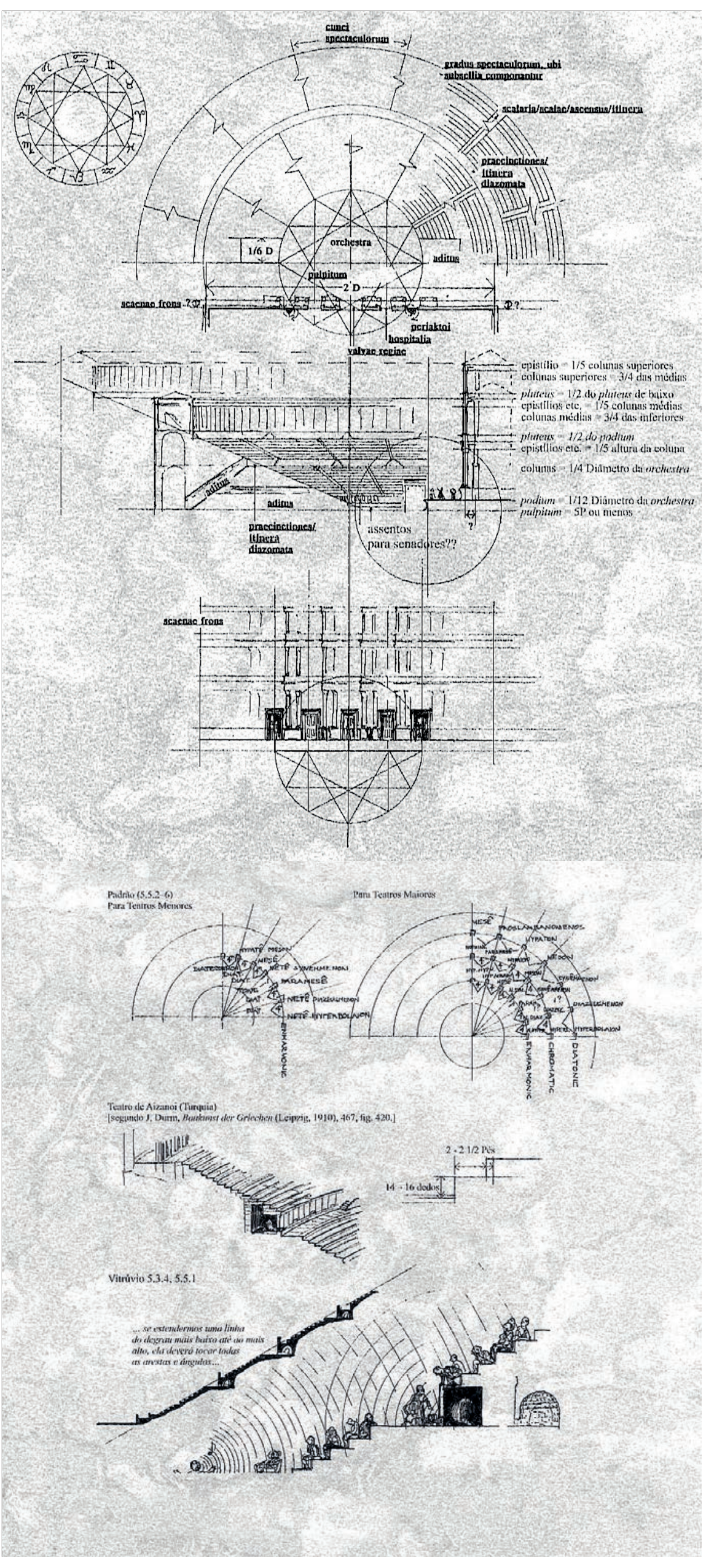

Fig. 185 - Desenhos interpretativos dos preceitos vitruvianos, segundo Thomas 
- Um sexto do diâmetro da orquestra marcará a largura dos acessos à mesma ${ }^{12}$.

- A largura da cena terá o dobro do diâmetro da orquestra ${ }^{13}$.

\subsection{7-Cavea}

Quando se aplicam estes princípios ao traçado da cavea do Teatro de Tongobriga reparamos nos seguinte aspectos:

Primeiro: ao inscrever os quatro triângulos equiláteros na orquestra torna-se possível determinar a profundidade e a largura do pulpitum, assim como a posição da frente cénica. Estes preceitos representam, antes de mais, coincidências com o traçado da quadrícula da cidade: em que a largura do pulpitum corresponde a um actus (o que significa que o diâmetro da orquestra é de meio actus), e a posição da frente cénica alinha com a metade do actus (fig. 186).

Segundo: ao dividir a cavea em seis cunei, e, posteriormente, alternar a posição dos acessos correspondentes a cada cavea ${ }^{14}$, reparamos que a posição dos drenos radiais aparenta corresponder ao traçado vitruviano. Em ensaios anteriores ${ }^{15}$, tínhamos verificado que os eixos destes drenos não eram concêntricos; e agora verificamos que a sua posição não é aleatória (fig. 187).

\subsection{8 - Corpo cénico e Pórtico Postscaena}

No que diz respeito ao corpo cénico (scaena) do teatro romano, Vitrúvio descreve alguns preceitos para o seu traçado, essencialmente sobre a sua posição, altura e distribuição das portas (valva); o que não é suficiente para determinar a configuração desta peça. Mas se observarmos diferentes exemplos de teatros, é possível verificar certas proporções que se repetem. Desta forma, podemos usar essas proporçõe para especular sobre o desenho da scaena e pórticos postscaenium do teatro de Tongobriga.

\section{${ }_{12}$ Vitrúvio $V, 6,5$.
${ }_{13}$ Vitrúvio $V, 6,6$.}

escadas serão em

"Os cunneos das bancadas deverão ser traçados de modo que as subidas e as escadas que os dividem correspondam, ate ao primeiro murete, aos ângulos dos triángulos riores deverão corresponder acessos alternados". Vitrúvio, $V, 6,2$. Traduç̃o de Justino Maciel. ${ }^{15}$ Ver pp. $128-129$

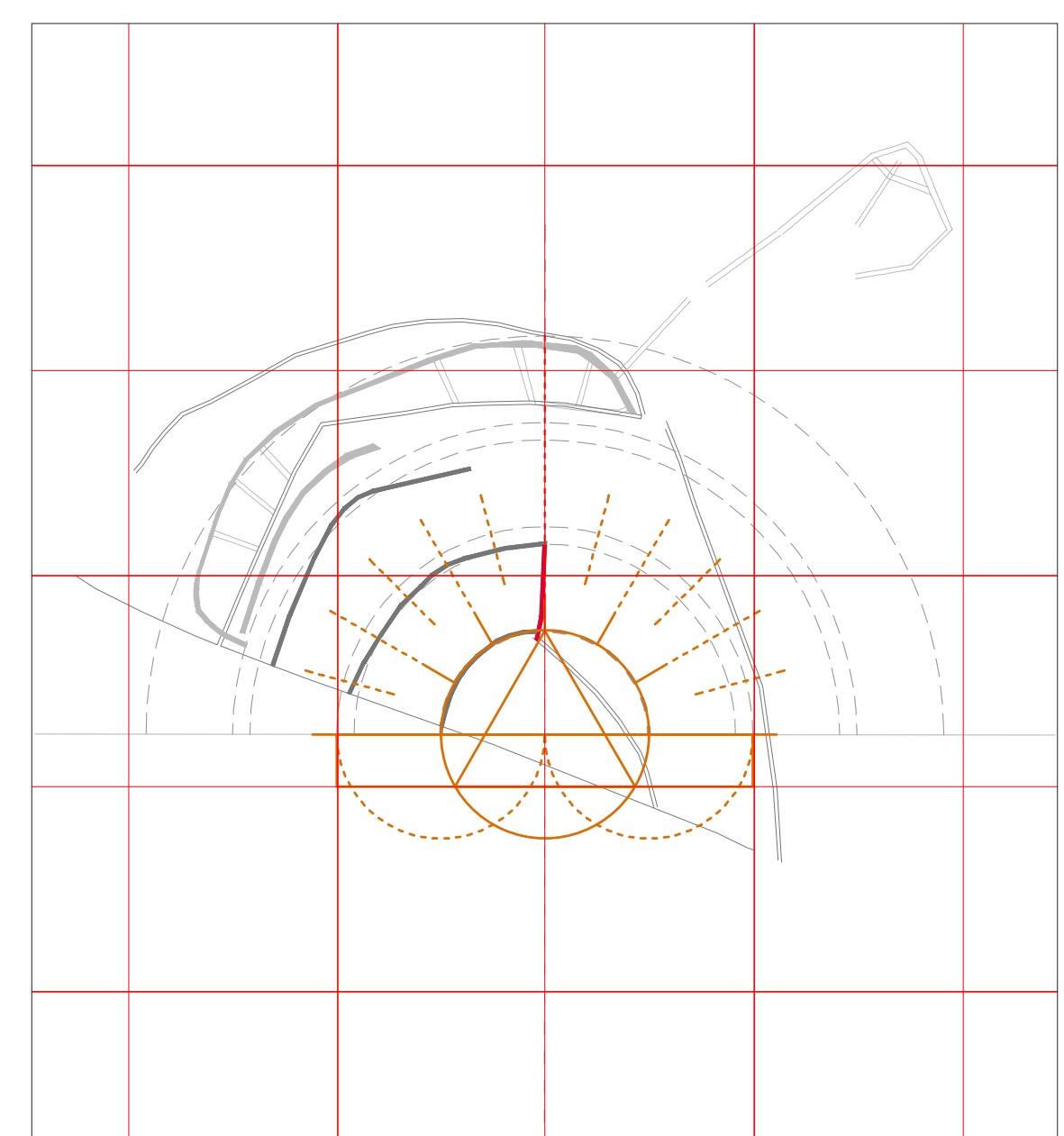
12 passus Fig. 186 - Aplicação do traçado de Vitrúvio no teatro de Tongobriga, por forma a
determinar o palco.
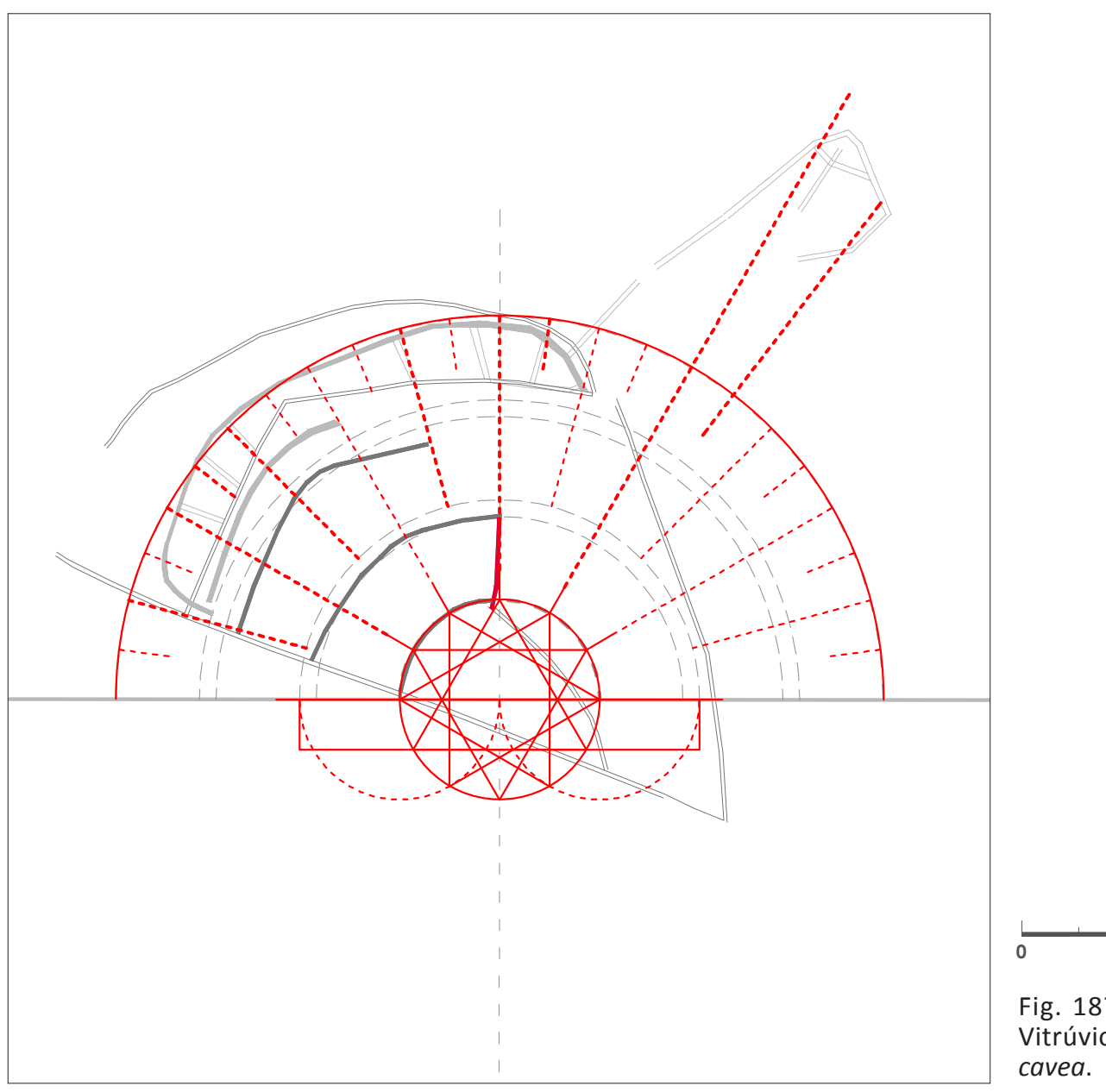
Dados os elementos apresentados até aqui, estamos cada vez mais convencidos que a hipótese de cavea com $68 \mathrm{~m}$ de diâmetro é que melhor se apropria à situação do teatro de Tongobriga. Por este motivo, vamos ter esse dado em conta na especulação acerca do corpo cénico e pórtico postscaena.

No desenho do corpo cénico é importante, antes de mais, determinar a sua posição face à cavea; o que significa determinar a posição dos aditus.

Segundo Vitrúvio, tal posição é determinada ao traçar uma paralela, para o lado da cavea, a partir do seu limite, com a distância de um sexto da orquestra ${ }^{16}$. Mas quando analisamos exemplos de teatros, verifica-se que há situações em que tal não acontece. $O$ que sucede é que essa linha é traçada, não para o interior da cavea, mas sim para o exterior, afastando um pouco o seu corpo cénico (fig. 188).

Neste particular aspecto, decidimos seguir o preceito de Vitrúvio.

Agora, posicionado o corpo cénico, verificamos proporções que se repetem em diferentes casos.

Uma das proporções que se verifica quase sempre é a relação de profundidade entre a front scaena e o proscaenium; estes apresentam-se com a mesma profundidade (fig. 189). Existem situações em que a front scaena é mais profunda, mas apenas devido a adossamento de um espaço interno que permite a circulação de espectadores (exemplos: teatro de Orange [fig. $189 \mathrm{~B}]$ ).

Relativamente à largura do corpo cénico, verificam-se várias situações: casos em que este tem a mesma largura que o diâmetro da cavea (ex.: teatro de Orange), casos em que este é menor (ex.: teatro de Bracara Augusta) e casos em que este é totalmente independente da cavea (ex.: Epidauro).

Para efeitos deste estudo, decidimos considerá-lo semelhante ao caso de Bracara Augusta, por razões óbvias ${ }^{17}$.

No que diz respeito ao pórtico postscaena, decidimos não aprofundar ou justificar em demasia o seu desenho, por considera que se podia estar a entrar num sentido de investigação meramente especulativo.

16 "Nas extremidades serão cortadas perpendicularmente as bancadas inferiores, de cada um dos lados das entradas, com uma largura igual à sexta parte do diâmetro da tituirão os arcos dos acessos". Vitrúvio, V, 6, 5. Tradução de Justino Maciel.

${ }^{17}$ As semelhanças que se têm constatado entre os dois casos ao longo da investigação.

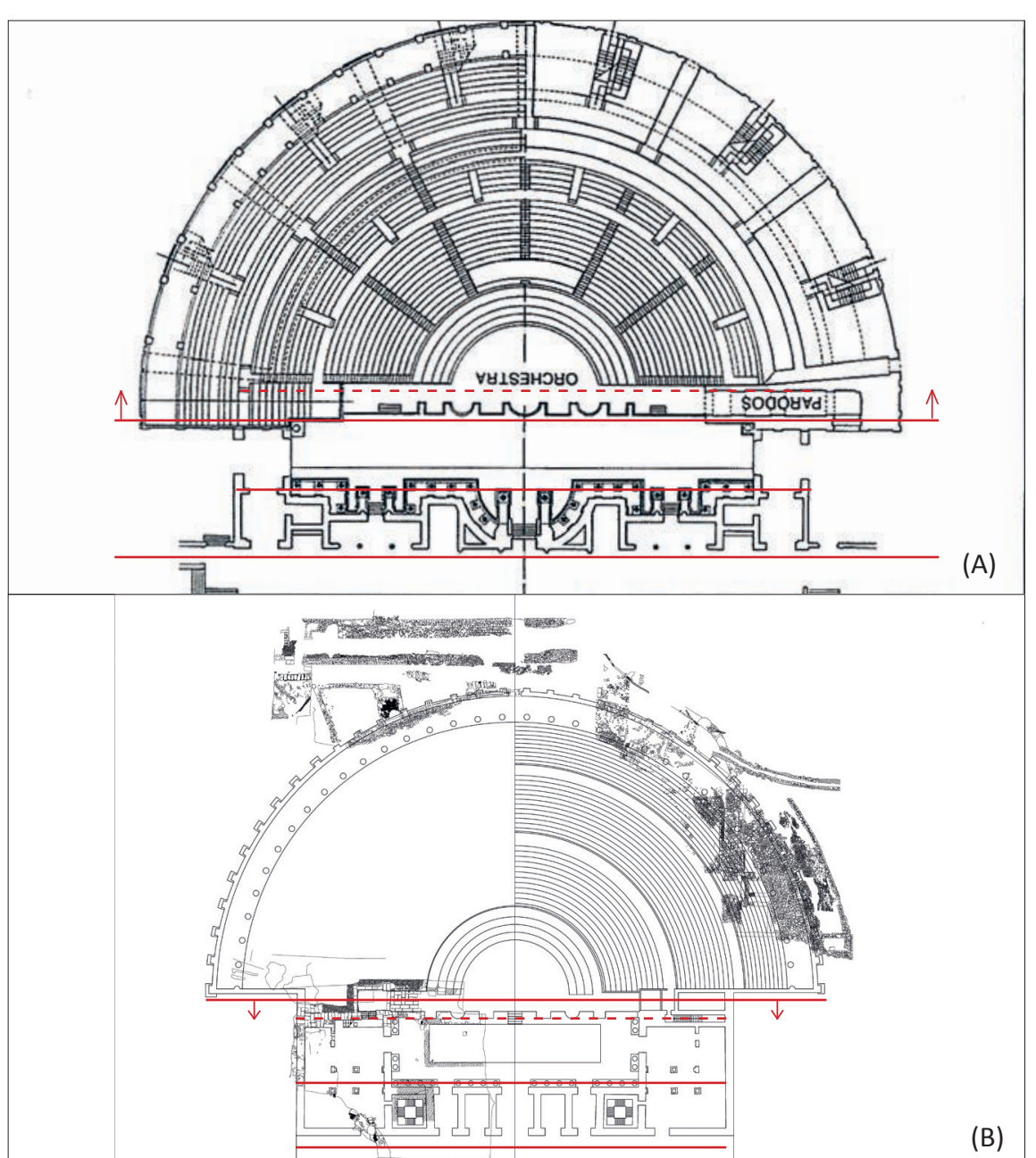

Fig. 188 - Posição dos aditus face à cavea. Exemplo do teatro de Mérida (A). Exemplo do teatro de Bracara Augusta.
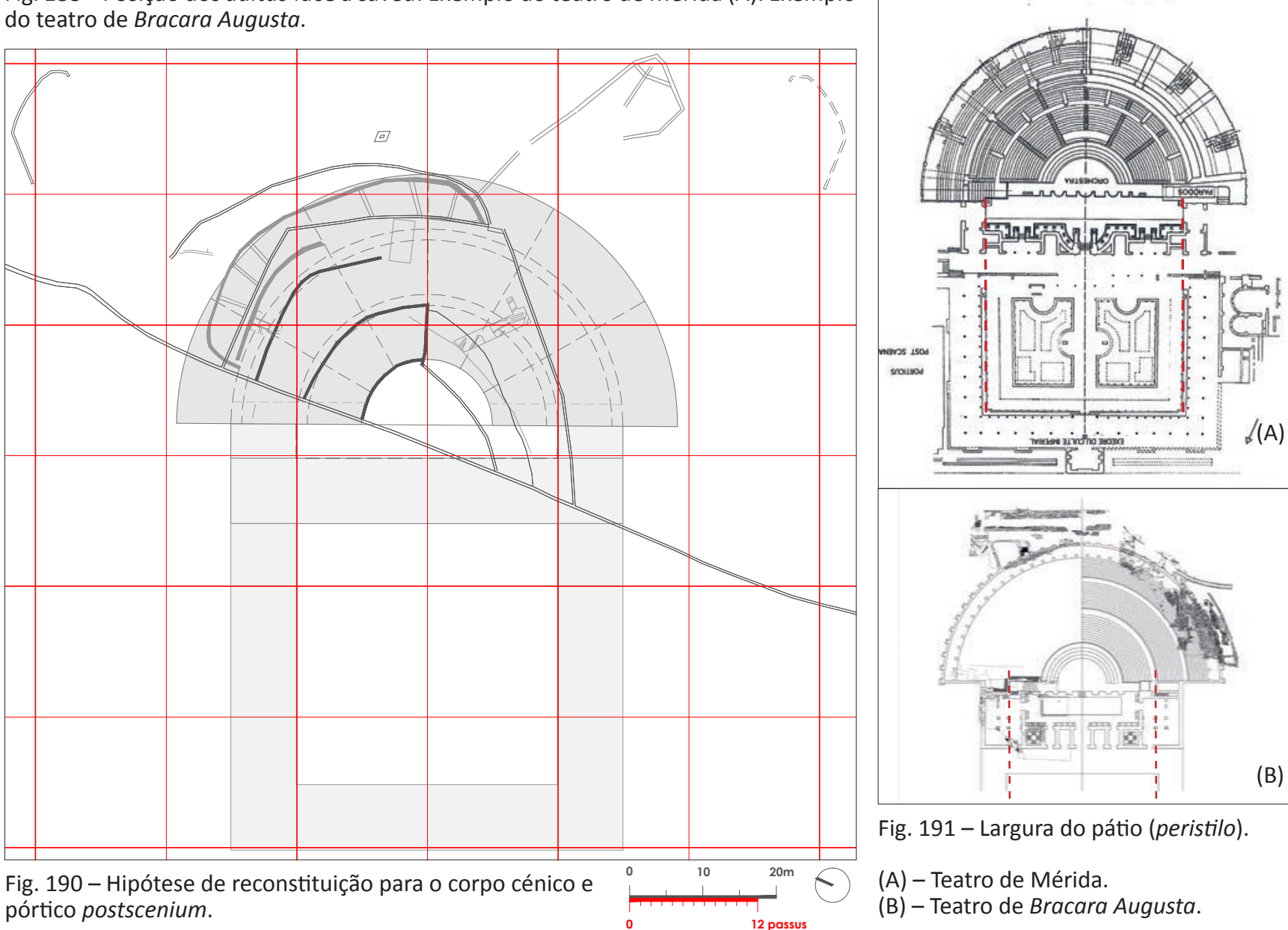

Fig. 191 - Largura do pátio (peristilo).

(A) - Teatro de Mérida.

- Teatro de Bracara Augusta 
Desta forma, a partir da hipótese da scaena apresentada apontamos apenas algumas indicações para o seu desenho; ao observar exemplos, é possível verificar dois princípios. O primeiro tem a ver com a largura do pátio, constatando-se (se observarmos os casos de Mérida, Bracara Augusta, Lepsis Magna e Pompei) que a largura do pátio (peristilo) é equivalente à largura do proscaenium (fig. 191). $O$ segundo tem a ver com a proporção largura-comprimento, ocorrendo duas situações: casos em que a proporção é igual, como se verifica na praça do forum, dois terços (exemplo: Mérida), e casos em que esta é quadrada (Bracara Augusta).

Para além dos dados referidos, outro princípio que nos parece muito importante é o alinhamento com o limite poente do forum; alinhamento este que proporcionaria uma composição de alçado do centro cívico para quem chegasse à cidade vindo de poente.

Assim, colocamos a hipótese de, a partir dos dados lançados, e à semelhança do Teatro de Bracara Augusta, o Teatro de Tongobriga ter um peristilo quadrado; com a diferença de estar limitado pelo corpo cénico e um tripórtico, cujo pórtico poente se encontrava alinhado com o limite do forum (fig. 190).

Após esta sequência de ensaios apresentamos um resumo que se materializa no traçado que se encontra na figura (fig. 192).

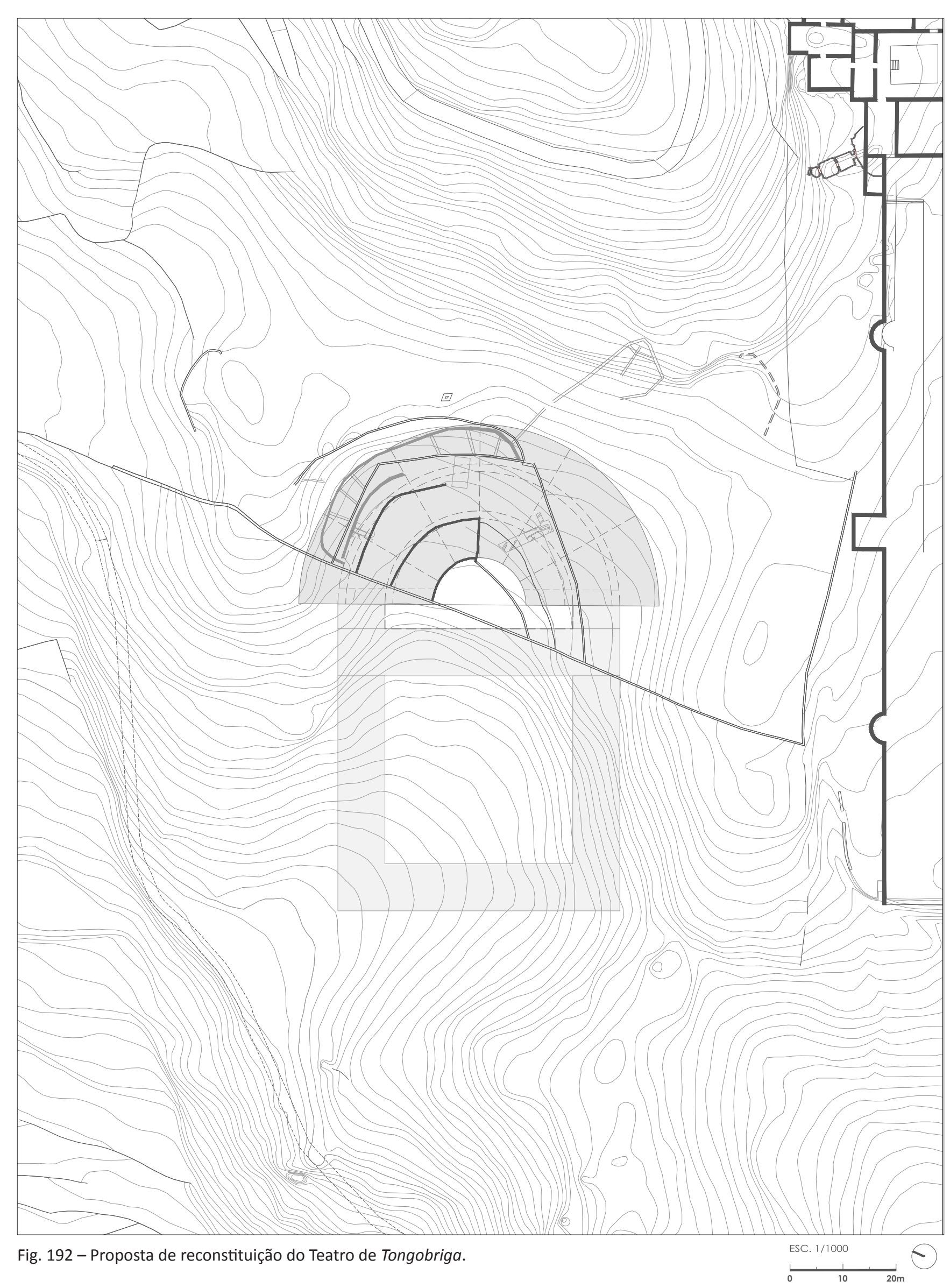




\section{4 - Anfiteatro/ hipótese de implantação}

Tendo em conta já se terem identificado as estruturas do teatro e do circo na cidade de Tongobriga, só restaria a presença de um anfiteatro nesta cidade para complementar o trio de equipamentos romanos dedicados ao entretenimento. Assim sendo, tendo po base a grelha actus proposta e a análise da morfologia do terreno, pensamos que Tongobriga poderá ter assistido à construção de um anfiteatro, cuja localização admitimos ter identificado.

A norte do teatro e do forum, um conjunto de vestígios aparentam uma curvatura, orientada na mesma direç̧ão que a grelha da cidade, e que parece sugerir a posição de uma cavea. Esta localização dista do eixo do teatro a mesma distância que o teatro dista do eixo do forum, existindo uma clara métrica na sua posição (fig. 193).

Tal implantação, que teria de ser confirmada com sondagens no local, parece responder a um conjunto de indícios, ali perceptíveis: uma seç̧ão de muro (identificado até aqui como muralha honorífica da segunda fase); uma inflexão da rua identificada como decumani, e cujo muro de sustentação compõe um arco com o muro referido; o talude no terreno que sugere a parte da cavea, assim como o que parece ser o praecintio; e, por fim, um talude rectilíneo que alinha pelo fundo do forum.

Trata-se de um dos poucos espaços a esta altitude, ainda hoje em uso para fins agrícolas, um dos poucos espaços que é constantemente lavrado. Tal dado poderá indicar que estas terras, quer transportadas, quer por erosão do terreno, se tenham acomodado a este espaço côncavo deixado pela ruína do equipamento.

A hipótese de traçado ${ }^{1}$ para o anfiteatro implanta-se no terreno segundo o conjunto de indícios referidos e de acordo com o quadriculado proposto (figs. 195 e 196). 0 eixo da curvatura limite sobrepõe-se aos muros salientados, enquanto que o diâmetro do eixo longitudinal se gere pela posição do teatro e o alinhamento com o limite poente do forum. Desta forma, os restantes dados são fornecidos pelo esquema tipo para o traçado de um anfiteatro romano.

Quanto ao seu enquadramento no quadriculado, o anfiteatro implanta-se de forma a ocupar nove unidades de actus quradratus ( $3 \times 3)$, em que o eixo de simetria se posiciona a meio da unidade de actus central.

${ }^{1}$ Recorremos ao esquema tipo proposto por Mark Wilson Jones, em Principles of Roman Architecture, p. 61 (fig. 194).

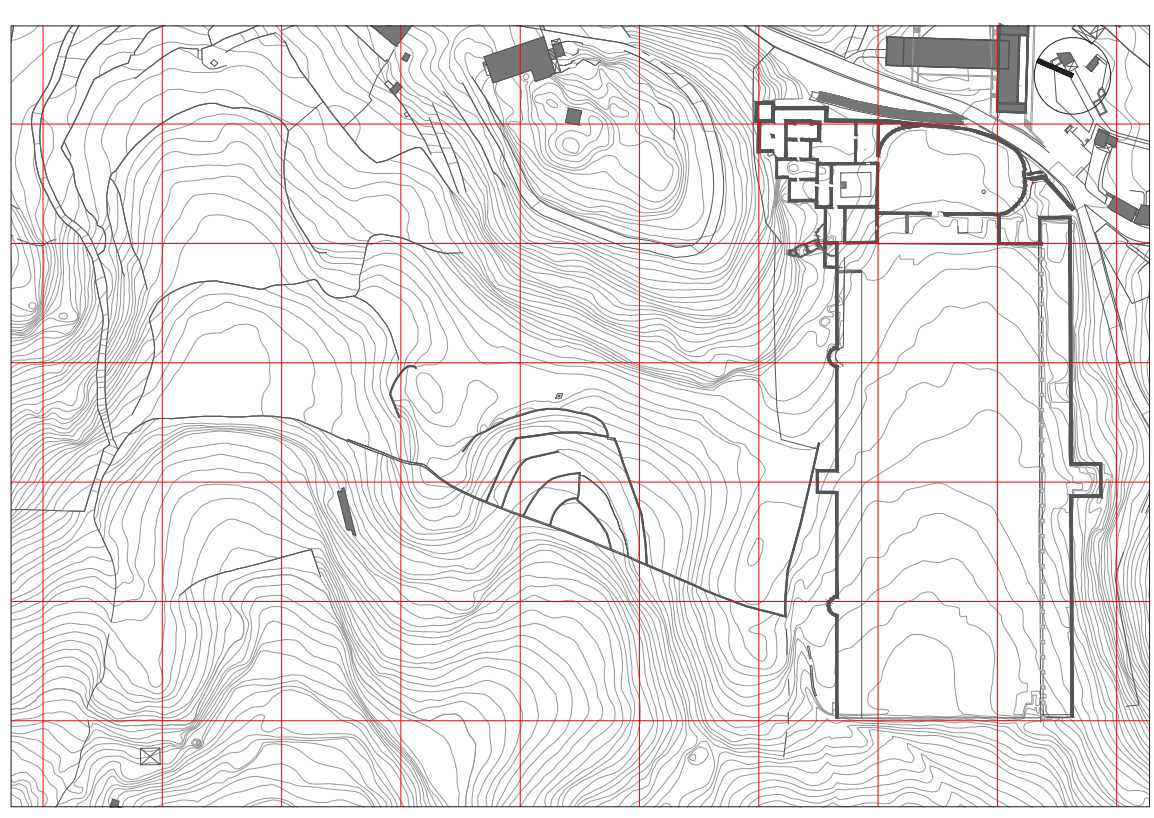

ig. 193 - Enquadramento do centro cívico no quadriculado actus.

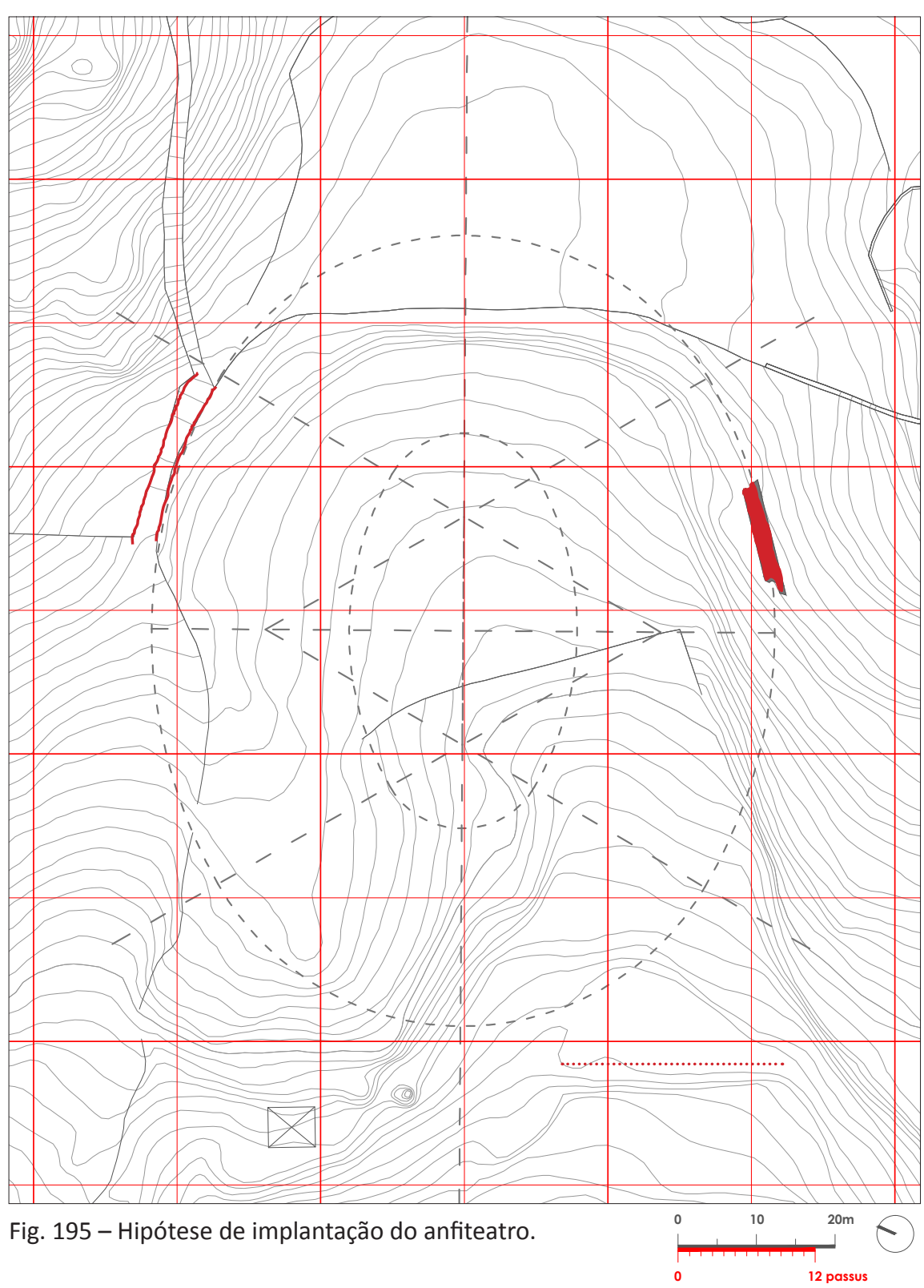

susus

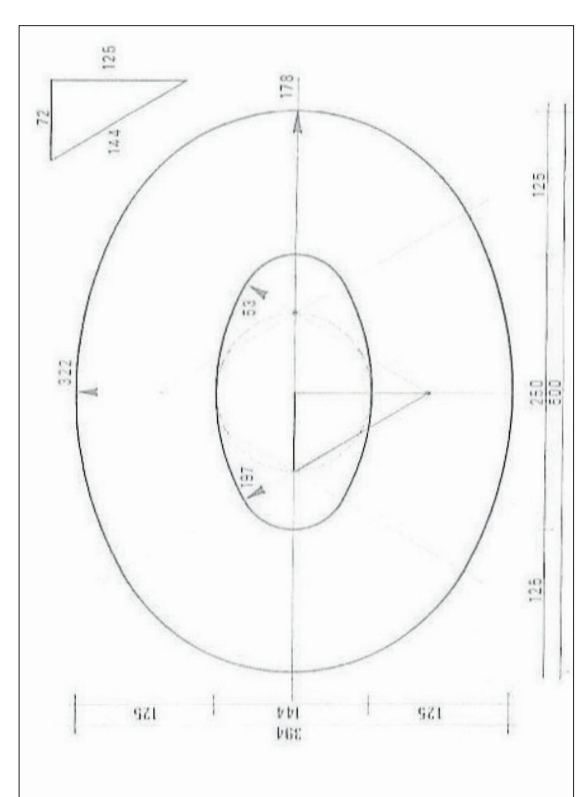

Fig. 194 - Traçado hipotético de Verona, tero-e-circulo-inscrito.

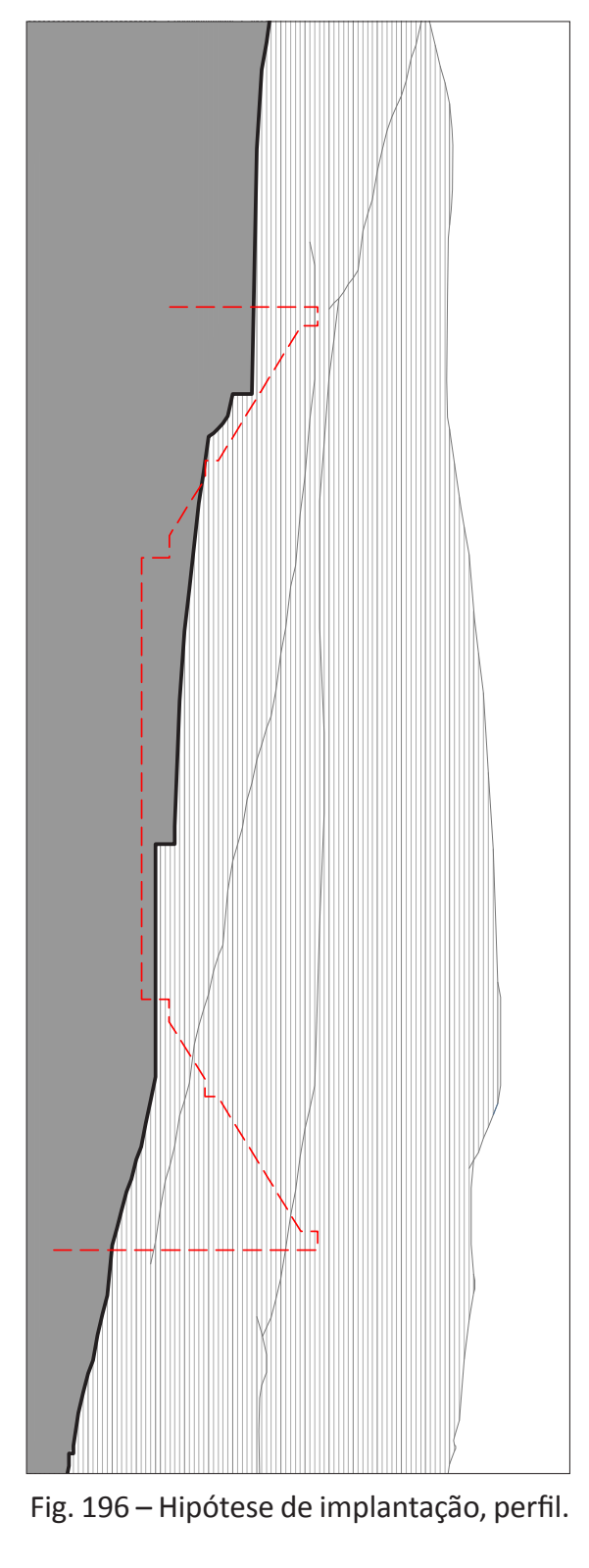




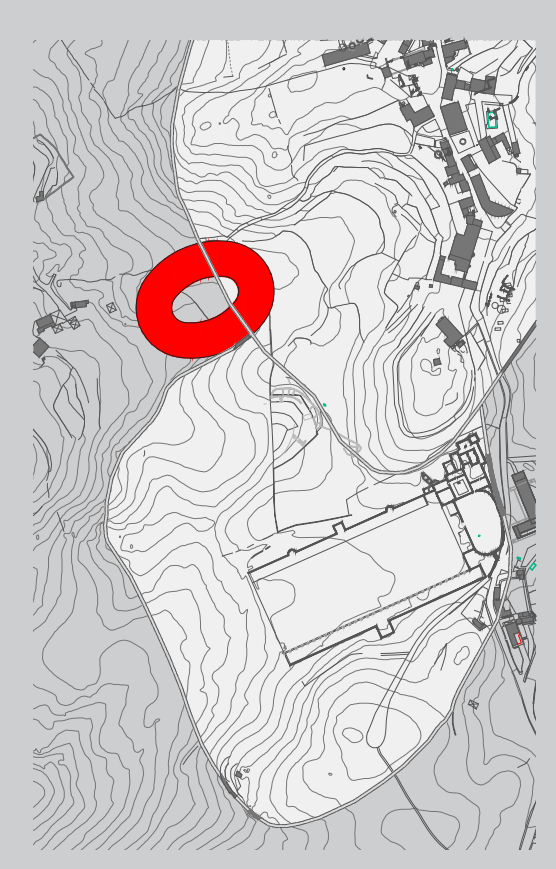

Com esta implantação, tanto na situação do teatro como na do anfiteatro, resulta que no desenho urbano duas das ruas decumano venham embater na superfície curva da fachada² (fig. 195).

No que diz respeito à relação entre anfiteatro e teatro, esta implantação é muito semelhante ao caso da cidade de Mérida. Verifica-se uma proximidade dos dois equipamentos, e uma composição urbana entre eles. Em Mérida, o teatro e o porticus postcenium têm um comprimento equivalente ao maior eixo (longitudinal) do anfiteatro (fig. 197).

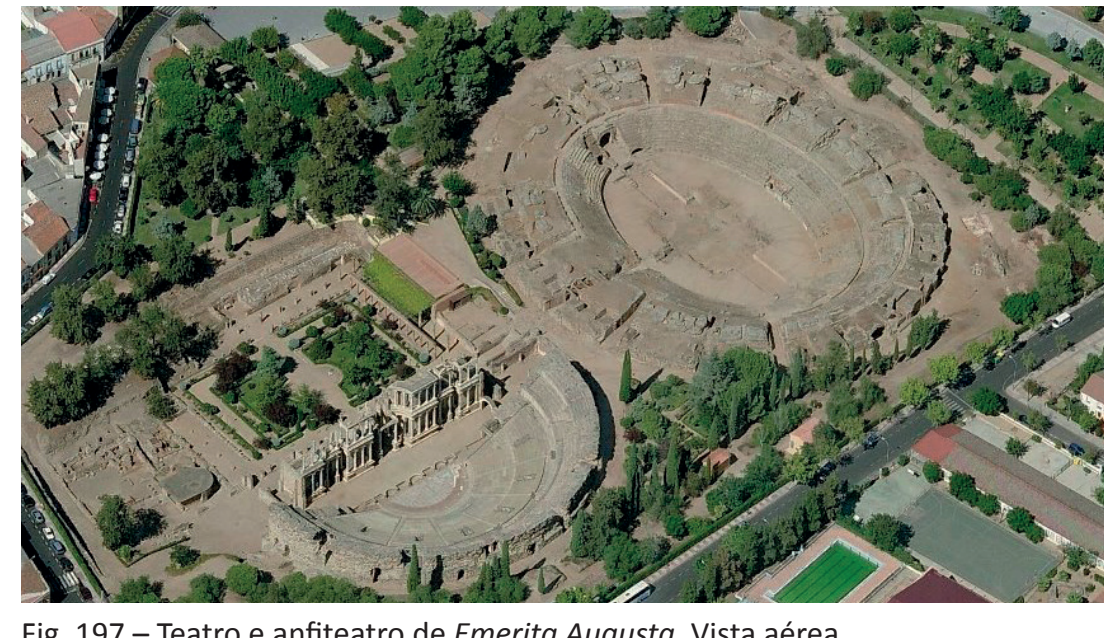

Fig. 197 - Teatro e anfiteatro de Emerita Augusta. Vista aérea.

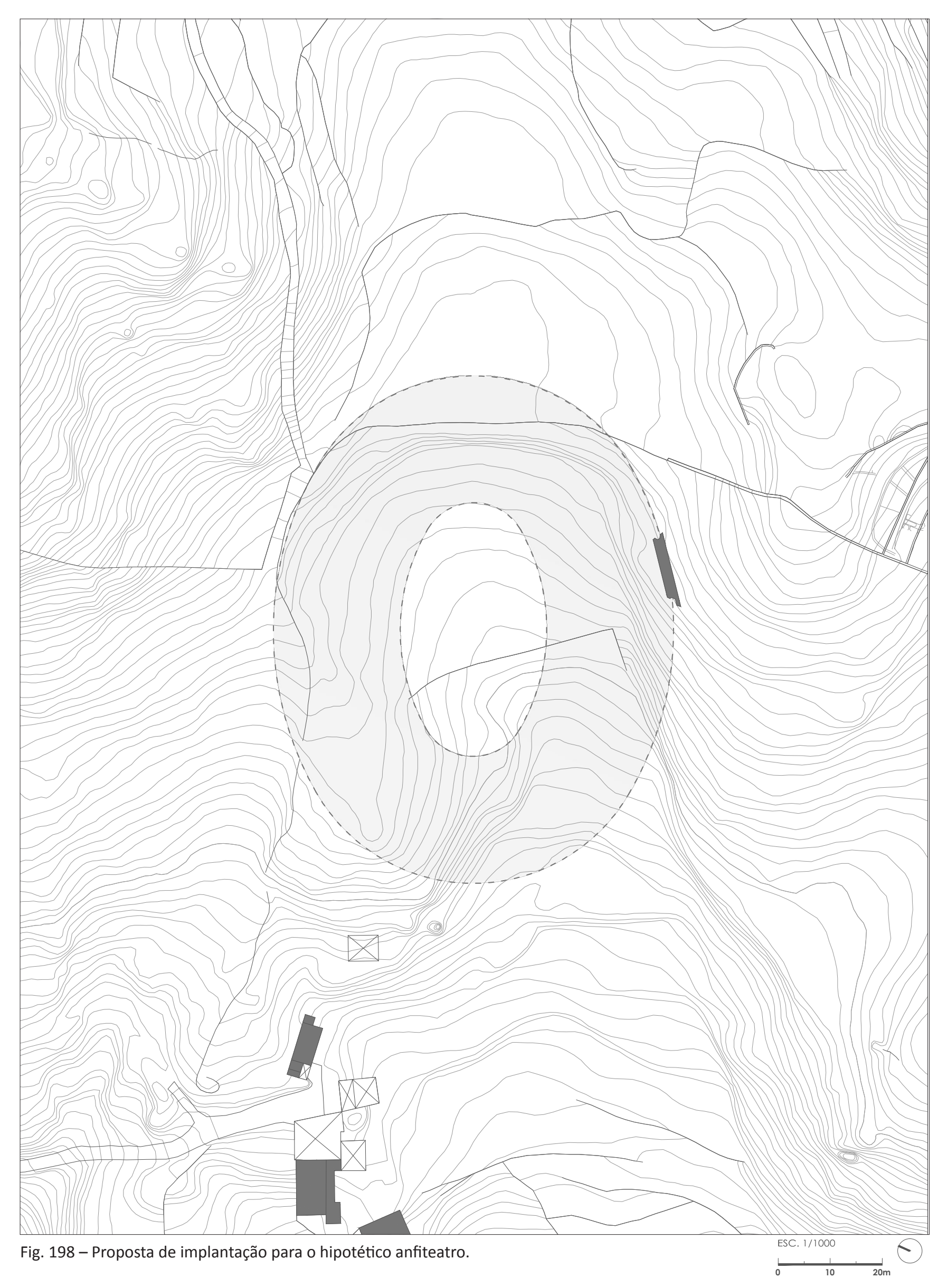

${ }^{2}$ Como exemplos onde isto sucede, temos o caso do anfiteatro em Conímbriga e o teatro de Bracara Augusta, entre outros. 


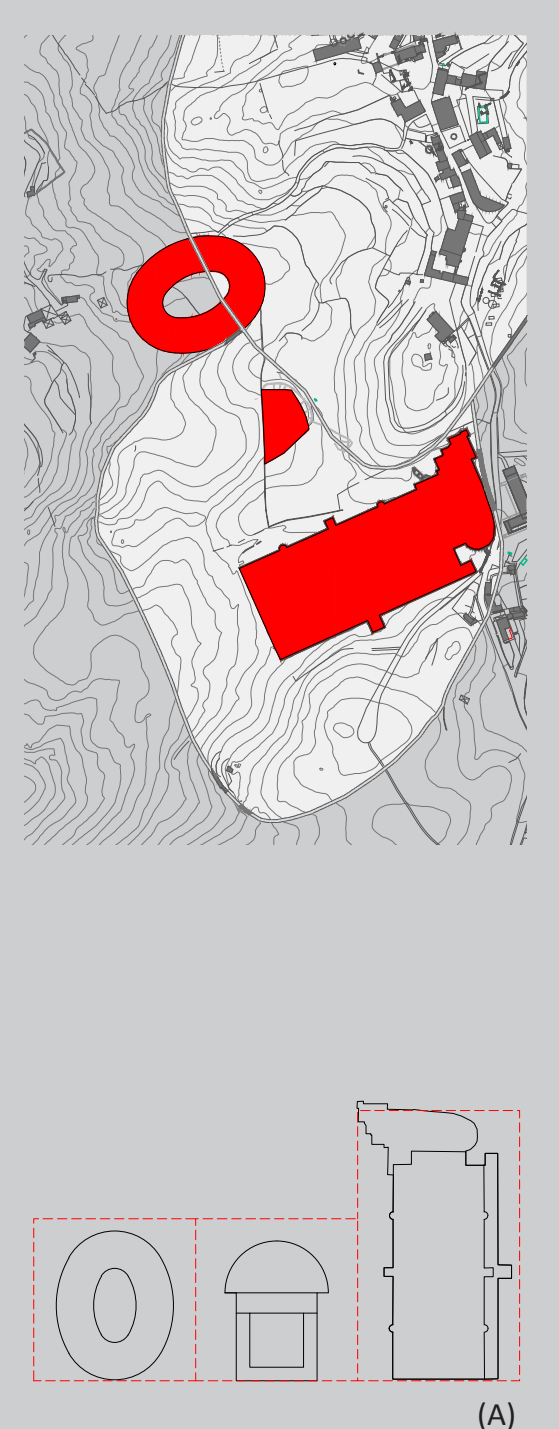

Fig. 199 - Esquemas de composição do centro cívico.

(A) - Áreas correspondentes a cada equipamento.

(B) - Posição de eixos em três actus.

mentos.

\section{5 - Centro Cívico - Reconstituição}

"A escavação de Tongobriga permite dizer que no final do século I, e ainda no século II, surge uma urbe, a cidade, como organismo sócio- económico que concentra não só elementos 'residenciais' mas também uma produção artesanal especializada em, certamente, actividades sistemáticas de 'troca' que justificavam a construção do forum. No caso de Tongobriga, podemos pensar que surgiu também, nessa época, como centro estruturado do poder - civitas ${ }^{1}$, com natural preponderância sobre a região envolvente" ${ }^{\prime \prime}$.

"Parece-nos que a construção das termas, basilica, praça, templo e demais edifícios públicos corresponde a atitudes que se resumem a um único objectivo, o de dotar este centro urbano de equipamentos colectivos que, pela sua monumentalidade e 'riqueza' arquitectónica, impuseram Tongobriga como centro de atracção e decisão"s.3.

O centro cívico foi, assim, o resultado da expansão do espaço urbano, por volta do século II d.C., e deu origem a um conjunto de equipamentos públicos que impuseram Tongobriga no território (fig. 200).

Nesta investigação, estudámos dois desses equipamentos, o forum e o teatro, e admitimos ter descoberto traços de um terceiro o anfiteatro. Em resumo: às hipóteses e propostas lançadas para cada um dos equipamentos estudados, acrescentamos uma composição para o centro cívico (fig. 201 e 202)

Os três equipamentos implantam-se lado a lado, a sudoest da área habitacional, onde a sua relação urbana e enquadramento $n$ cidade estão claramente relacionadas com a disposição da grelha actus quadractus que propusemos para a cidade de Tongobriga.

Tanto a área do teatro como a área do anfiteatro se enquadram, cada uma delas, em nove unidades de actus quadractus (3x3). Já o forum enquadra-se em doze unidades ( $3 \times 4)$, sendo a sua largura de três actus (fig. 199 A). Desta forma, a distância a eixo entre cada uma delas é também de três actus (360 pés) (fig. 199 B). Outra relação proporcional que é possível estabelecer através da grelha é a relação entre a largura de cada equipamento e o espaço livre deixado entre eles. Cada equipamento tem dois actus de largura, e o espaço deixado entre si um actus (fig. 199 C).

${ }^{1}$ Ver "Roma, Berço da Latinidade", in A Civilização Latina, Émile Gondurachi, 1989, pp. 85-107. Referido por Lino Tavares Dias.

'Lino Dias, Tongobriga, 1997, p. 29.

Idem, p. 30.

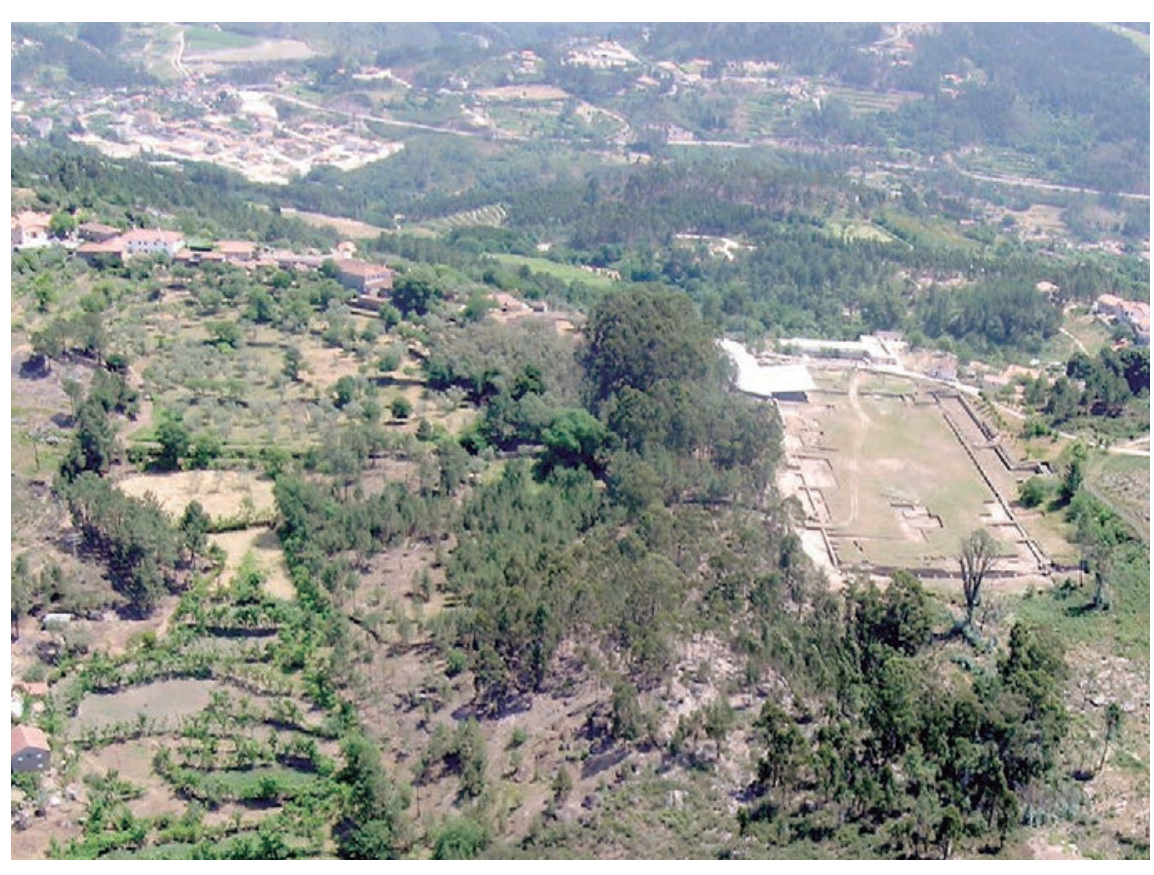

Fig. 200 - Espaço do centro civico. Vista

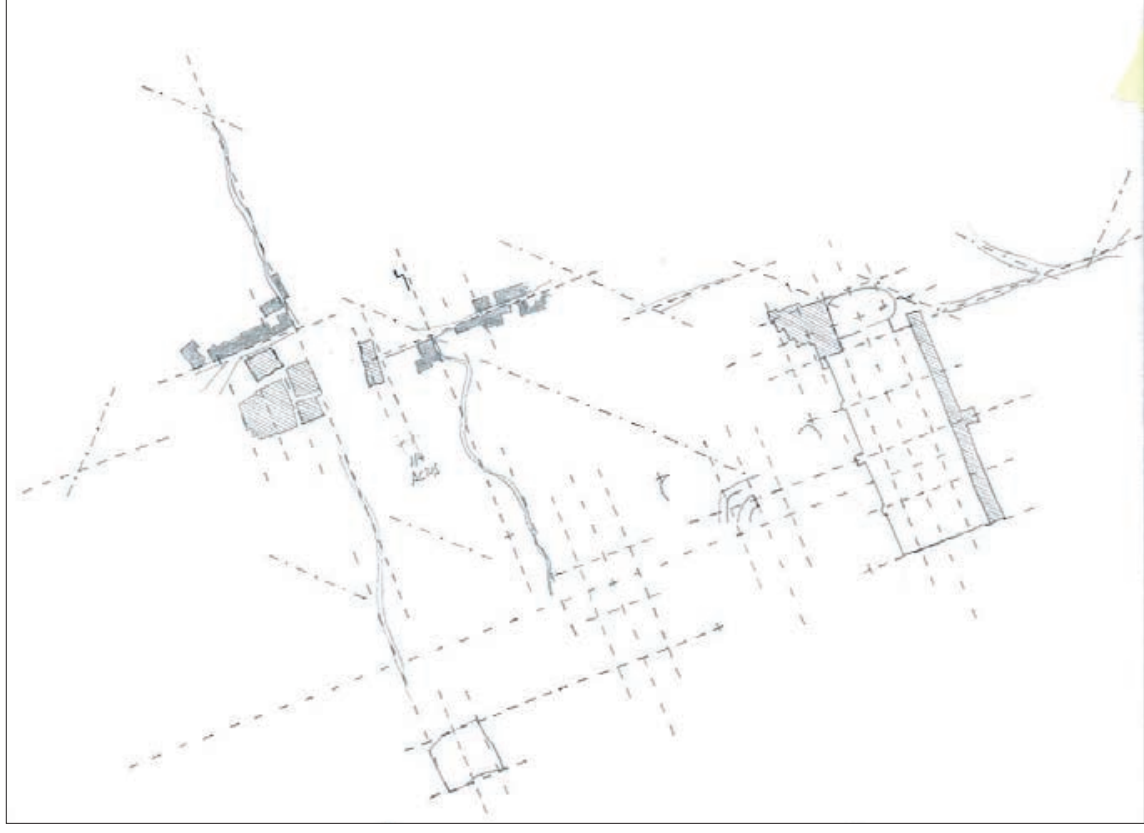

Fig. 201 - Conjunto de elementos assinalados através do uso do quadriculado actus zamento. Com a reconstitução do centro

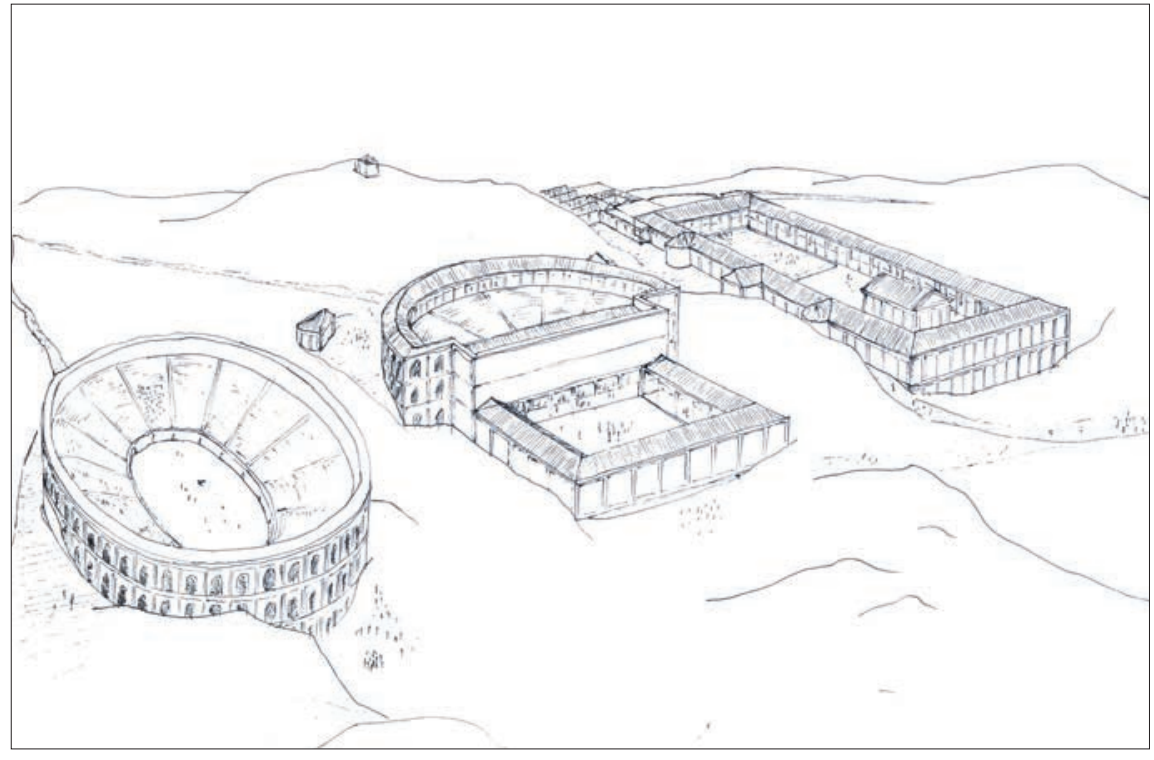
Fig. 202 - Ilustração da reconstituição do
centro cívico, num período posterior a
"Claudio-Nero". 


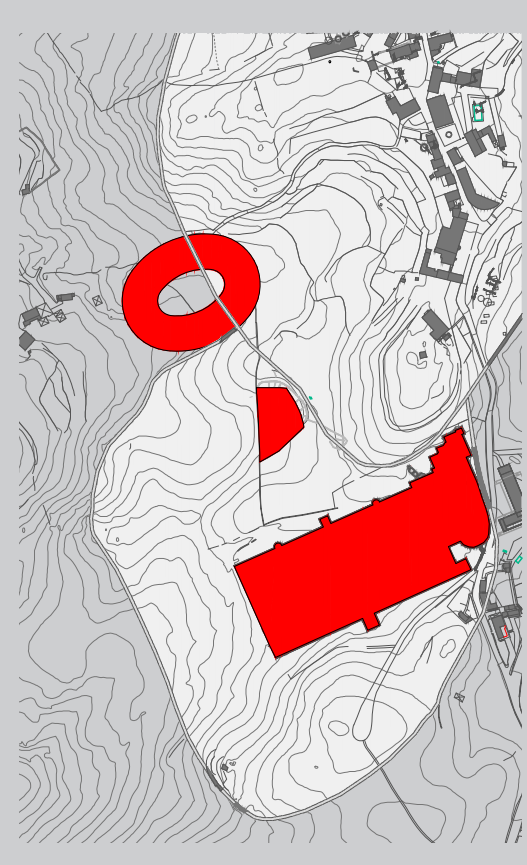

Apesar do relevo acentuado que se faz sentir em Tongobriga, 0 rigor com que os equipamentos do centro cívico se encontram implantados e enquadrados segundo o quadriculado actus é realmente impressionante ${ }^{4}$.

A partir desta disposição de equipamentos é-nos possível perceber a relação do centro cívico com a cidade, assim como a sua posição face à muralha do século I a.C. (figs. 203 e 204).

No que diz respeito à ligação entre centro cívico e área habitacional, foi referida a possibilidade de existência de uma rua a $45^{\circ}$, que ligaria ambas as áreas ${ }^{5}$. É interessante perceber que essa rua confluiria junto ao espaço do teatro (o equipamento que se encontra no centro cívico da cidade).

Quanto à posição dos equipamentos face à muralha do século I a. C., é curioso entender a sua implantação, que contorna o primeiro espaço urbano. $O$ caso das termas é bastante peculiar, apesar de estas se implantarem numa unidade de actus quadractus, pois repara-se que o equipamento tem uma forma de cunha adaptada entre as duas fases da muralha.

No desenvolver da investigação, certos dados levaram a contemplar a possibilidade de a posição do teatro e anfiteatro estarem trocadas. Dada a semelhança destas duas estruturas-tipo, não seria algo difícil de acontecer.

Como a investigação parte da análise dos vestígios e investigações realizados, seguimos o raciocínio de que se o teatro e circo já se encontravam identificados, os indícios que localizámos teriam que pertencer a um anfiteatro. Mas, na realidade, se esquecermos ess identificação prévia, ao analisar a topografia existente a troca de posição destes dois equipamentos constitui uma hipótese totalmente plausível. Trata-se, assim, apenas de leitura topográfica, a necessita de comprovação arqueológica (fig. 205).

${ }^{4}$ Tal foi o rigor da implantação realizada pelos romanos que foi possível detectar um erro de inserção do forum no ficheiro do levantamento aerofotogramético realizado ${ }^{5}$ Ver pip $94-95$

${ }^{6} \mathrm{~A}$ hipótese de os vestígios existentes na zona do teatro terem pertencido a um anfi-
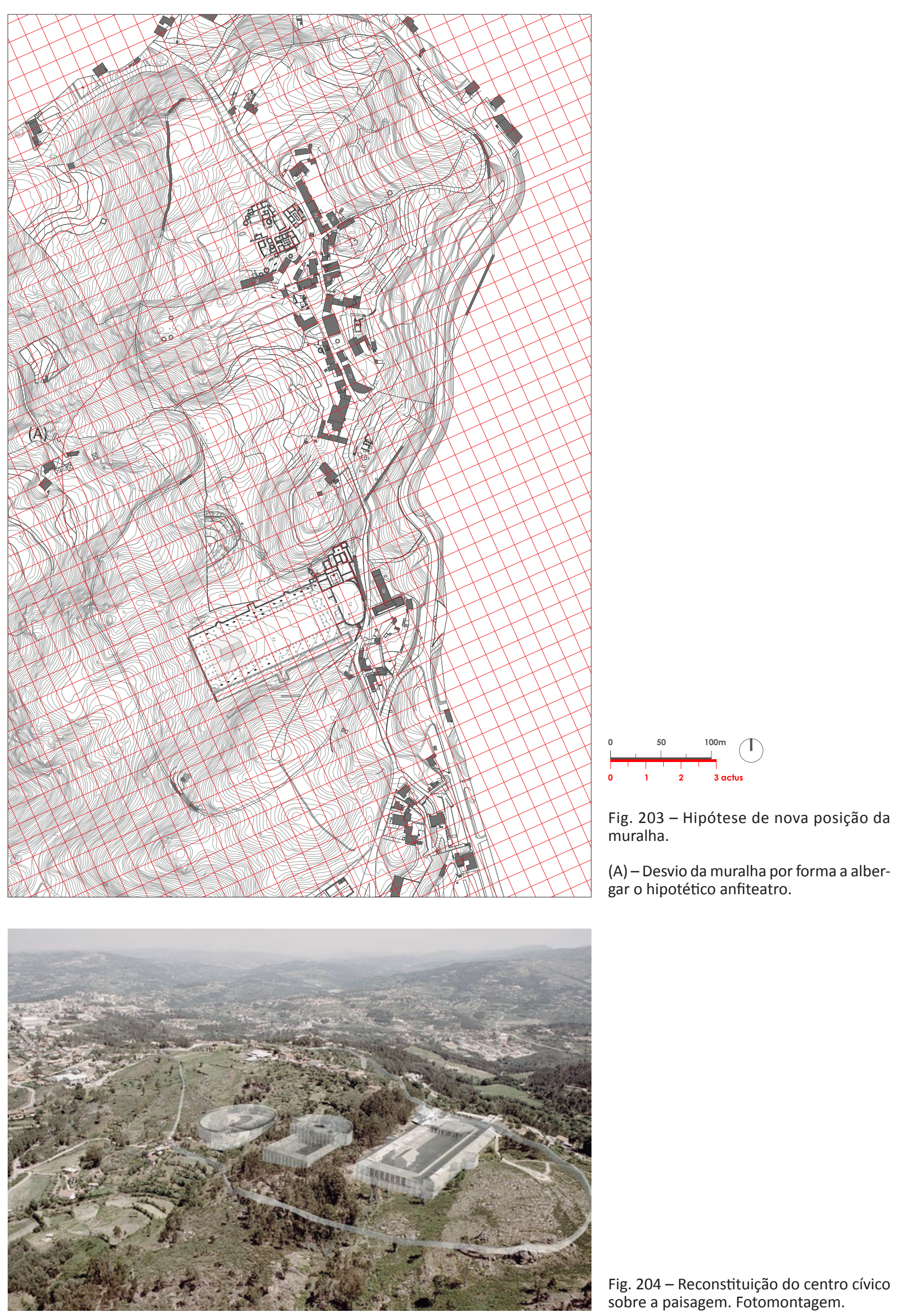

Fig. 204 - Reconstituição do centro cívico

- 


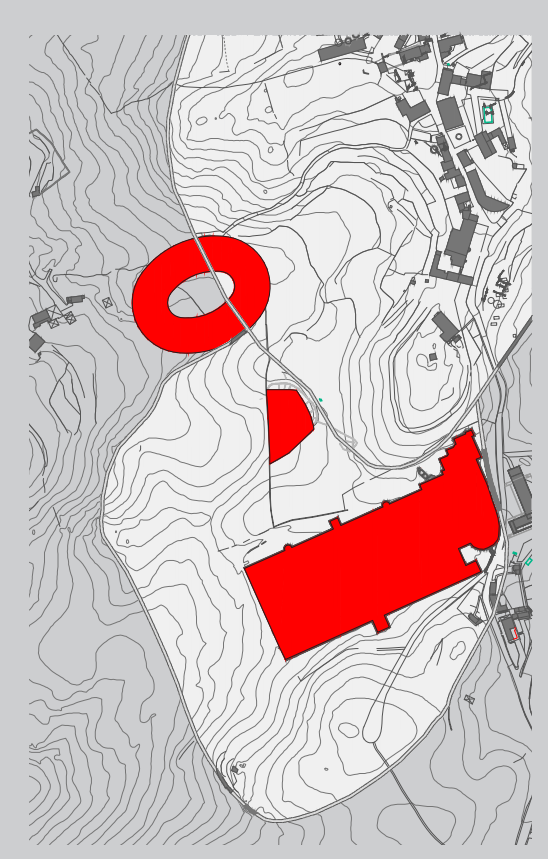

A partir desta hipótese para o centro cívico (quer na proposta que defendemos, quer na versão que acabamos de mencionar) deve-se reexaminar a posição da muralha da segunda fase da cidade.

Ao propor a existência de um terceiro equipamento, ultrapassamos os limites que estipulámos para a cidade de Tongobriga na primeira parte do livro (fig. 206). Um dos fragmentos que se considerava da muralha da segunda fase passa, assim, a pertencer à estrutura desse terceiro equipamento (fig. $203 \mathrm{~A}$ ).

Estes dados levam a que a dita "bolsa" amuralhada seja um pouco maior (fig. 205).

Outra hipótese contempla elementos que já apontámos ao longo da investigação, como a extensão dos decumani identificados e a parcela de terreno amuralhado. Estes elementos compõem um conjunto de indícios que levam a considerar a possibilidade de muralha da segunda fase ter abrangido bastante mais área da encosta poente; o que retoma uma das hipóteses mencionadas na primeira parte deste livro.
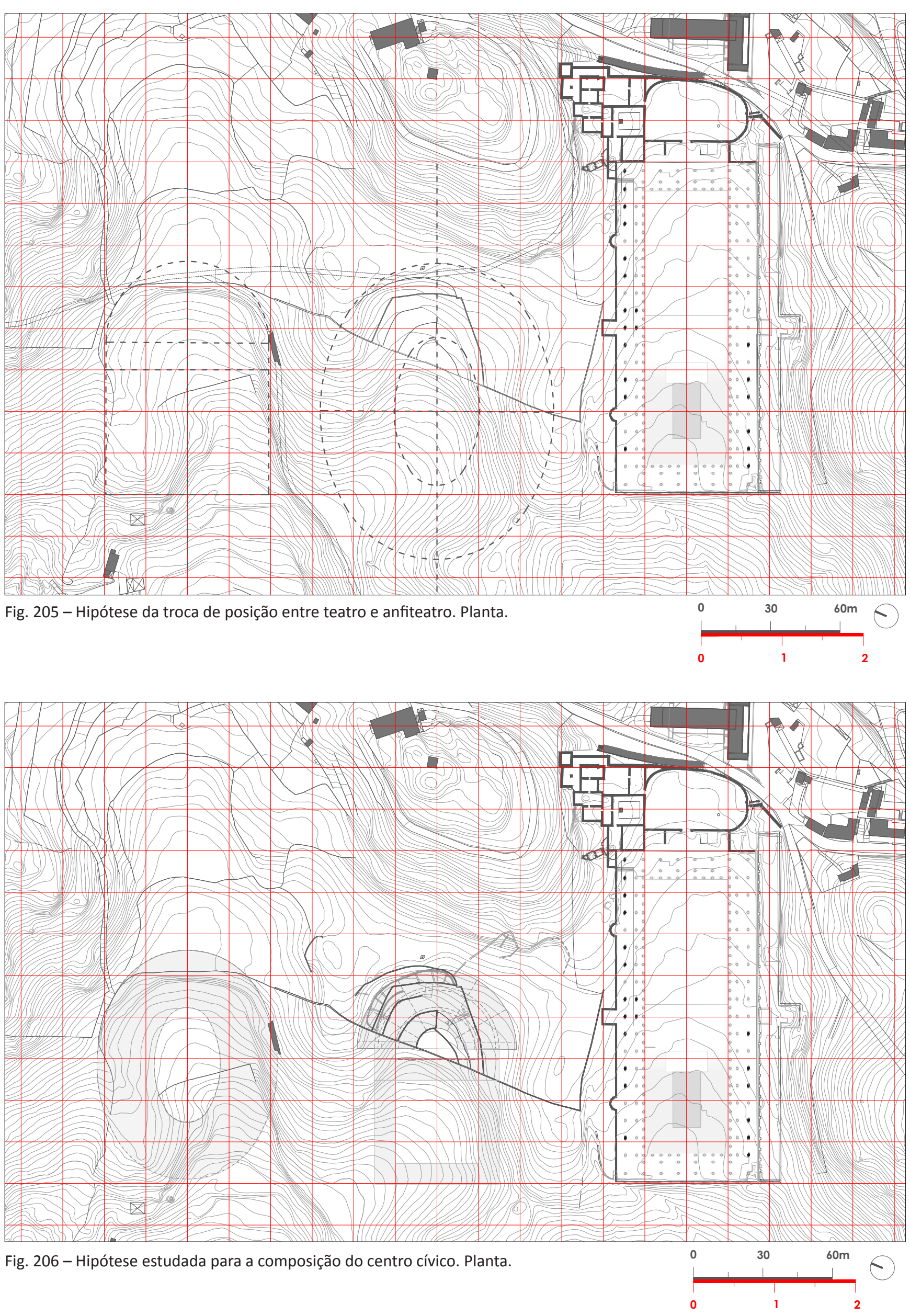
Foi objectivo desta investigação compreender a vivência e integração na paisagem do centro cívico de Tongobriga, bem como chegar a uma reconstituição conjectural do mesmo.

Pretendia-se igualmente demonstrar a utilidade dos processos de desenho e da lógica de pensamento do arquitecto neste campo de trabalho; demonstrar como a análise em desenho e o cruzamento de informação, bem como a limpeza de certos elementos estranhos, poderia auxiliar na detecção de pistas fundamentais à investigação; e, desta forma, trazê-las à luz da análise e discussão.

Entendemos também que esta reconstituição não constitui um projecto de reconstrução, mas sim um conjunto de elementos desenhados que permitem a visualização de uma hipótese conjectural, em torno de uma parte da história que se esvaeceu com o tempo.

Assim, apresentamos uma síntese composta pelos diferentes raciocínios e conclusões que se foram atingindo ao longo da investigação; bem como com o contributo do desenho em todo o processo.

Num projecto de investigação cujo objectivo inicial apontava apenas para a reconstituição desenhada do teatro romano de Tongobriga, o desenho mostrou-se de tal maneira uma ferramenta vantajosa para a análise que se sentiu a necessidade de expandir o objecto de estudo para todo o centro cívico.

Através deste estudo, acabámos por desvendar um quadriculado estruturador da cidade de Tongobriga; analisámos e estudámos o forum e o teatro, equipamentos pertencentes ao centro cívico e, ainda, admitimos ter desvendado a existência de um hipotético terceiro equipamento, o anfiteatro ${ }^{1}$

No decorrer da investigação, chegámos então à aplicação de um quadriculado actus na cidade de Tongobriga. Este novo elemento mostrou ser um dado muito vantajoso para a investigação. Permitiu-nos enquadrar as estruturas da cidade, relacionando-as entre si; articulação que se revelou bastante evidente na relação entre o centro cívico e as áreas habitacionais, principalmente após a detecção do desvio (ver: Des. 2.01)2. O quadriculado actus permite-nos também identificar coincidências com elementos actuais, um pouco 
por toda a cidade, assim como permite a identificação de elementos romanos no centro cívico. Exemplo disso é a estrutura simétrica no espaço do teatro ${ }^{3}$ e do novo equipamento, o hipotético anfiteatro ${ }^{4}$ onde a análise topográfica também foi relevante ${ }^{5}$. Por fim, este quadriculado constituiu igualmente um apoio de confirmação na análise da composição dos equipamentos do centro cívico, em particular no forum e no teatro ${ }^{6}$.

$\mathrm{Na}$ análise individual de cada um destes equipamentos o desenho teve papéis distintos, que correspondiam a necessidades que iam de encontro ao estado dos vestígios existentes.

No caso do forum, partimos de um enquadramento bem definido (os parâmetros limite do equipamento), tendo estes fornecido uma matriz sólida para a análise da sua ocupação e organização interior. A partir de módulos de fracção do actus, verificámos certas métricas e proporções, que se mostraram relevantes na sua composição ${ }^{7}$. A análise da distribuição da sapata de colunas permitiu-nos, por sua vez, através do desenho, desvendar uma hipótese de distribuição dos pórticos no forum; o que nos possibilitou, depois, em conjunto com outros elementos, especular sobre a praça e a posição do templo.

No caso do teatro, ao contrário do forum, partimos de um conjunto reduzido de elementos. Aqui, o desenho teve um papel fundamental na análise desse conjunto, por forma a chegarmos a uma hipótese de traçado para a cavea; mas também na sua integração e relação com o forum. $O$ desenho, em conjunto com a análise topográfica e o enquadramento da grelha actus, permitiu-nos detectar a estrutura simétrica, cuja a função ainda se desconhece ${ }^{8}$. E, por fim, embor numa vertente mais especulativa, procurámos delinear o desenho do corpo cénico e do pórtico postscaena ${ }^{9}$.

No caso do hipotético anfiteatro, em consequência das análises anteriores (quadriculado, reconstituição topográfica, traçado do teatro), a análise topográfica, em conjunto com o quadriculado, possibilitou a detecção de um conjunto de elementos que aparentam configurar a posição de uma cavea. Dado já se terem desvendado a posição

$$
\begin{aligned}
& { }^{3} \text { Ver pp. } 134-135 . \\
& { }^{4} \text { Ver p. } 148-151 . \\
& { }^{5} \text { Ver Des. 1.03. } \\
& { }^{6} \text { Ver pp. } 102-143 . \\
& 7 \text { Ver pp. } 108-113 . \\
& { }^{8} \text { Ver pp. } 134-135 . \\
& { }^{9} \text { Ver pp. } 142-145 .
\end{aligned}
$$

do teatro e a localização do circo, entendemos que estes elementos poderiam corresponder a um anfiteatro.

O recurso ao desenho demonstrou, assim, diferentes contributos para esta investigação. Os resultados foram sempre, directa ou indirectamente, obtidos através do desenho: "um desenho que permitiu formular novas questões, esclarecer antigas dúvidas e arriscar novas hipóteses"10.

Mas não podemos deixar de parte outras ferramentas que auxiliaram a investigação em determinadas situações; ferramentas como o recurso aos preceitos vitruvianos e a comparação com outros modelos do período romano.

O recurso aos preceitos de Vitrúvio teve, assim, o seu contributo nesta investigação. Essencialmente na primeira parte, em que, ao mesmo tempo que se criava uma aproximação e familiarização com a cidade de Tongobriga, se procurava compreender os motivos da escoIha do sítio e que intenções estariam por trás dela.

Os ensinamentos de Vitrúvio foram-se verificando em todos os passos da análise da cidade; na escolha do sítio, na implantação ${ }^{11}$, na organização da cidade e, por fim, na construção dos equipamentos. No caso destes últimos, temos o exemplo da basílica paleocristãa ${ }^{12} \mathrm{e}$ da Casa do Impluvium ${ }^{13}$, em que se efectuaram breves análises, identificando-se a aplicação dos preceitos vitruvianos. Este dado demonstra não só o uso desses preceitos mas também o período de tempo em que foram aplicados (entre finais do século I d.C. e meados do século IV d.C.).

Esta verificação, na primeira parte do livro, permitiu averiguar a implementação de preceitos vitruvianos na cidade de Tongobriga; desta forma, partimos para a segunda parte conscientes de que poderíamos contar com a veracidade do seu uso, assim como contar com a sua utilidade na reconstituição do centro cívico de Tongobriga ${ }^{14}$.

Assim, já na fase de análise do centro cívico, recorremos aos preceitos de Vitrúvio para o desenho da praça no forum, e como apoio ao desenho de um traçado para o teatro de Tongobriga.

\footnotetext{
${ }^{10}$ Pedro Alarcão, Construir na ruina: a propósito da cidade romanizada de Conímbriga, 2009, p. 389.

${ }^{11}$ Ver pp. 46-47.

${ }^{12}$ Ver pp. $70-71$.
${ }^{13}$ Ver pp. $74-77$.

${ }^{14}$ Neste sentido, na compreensão da cidade e do terreno onde Tongobriga se implanta

também o desenho teve o seu papel. Para o efeito, foi desenhada uma reconstituicão

topográfica, que permitiu o desenho de diferentes fases de evolução da cidade.
} 
No forum, recorremos à proporção canónica para a praça, e à relação proporcional do templo. Estes dados permitiram optar entre duas hipóteses possíveis para a disposição dos pórticos do forum ${ }^{15}$.

No teatro, os preceitos sobre este equipamento serviram para averiguar, no traçado proposto, a possibilidade de os drenos radiais não se encontrarem distribuídos de forma aleatória. Também se recorreu a preceitos vitruvianos para dar início à especulação sobre a posição do corpo cénico do teatro, determinando dessa forma as dimensões e proporções do palco ${ }^{16}$. Na especulação do porticus postcenium, recorremos essencialmente à comparação ${ }^{17}$.

A comparação foi usada de duas formas ao longo desta investigação. Em primeiro lugar, ocorria como complemento. Recorremos a exemplos que fundamentassem as teorias que surgiam ao longo da análise dos equipamentos.

Esta situação é patente no caso do forum, quando analisámos a distribuição de colunas, em que a nível de desenho surgiam certas explicações que procurámos verificar com exemplos. Constatámos assim, nos casos da agora de Smyrne, na Turquia, e numa reconstituição do forum de César, em Roma, a duplicação de colunas na colunat junto à praça. Na distinção entre um pórtico com duas ou três colunatas, referimos os mesmos exemplos ${ }^{18}$.

No caso do teatro, a comparação decorre com o teatro de Bracara Augusta. Por se tratar de um caso próximo de Tongobriga, recorremos a este exemplo para verificar o traçado proposto. Como se constataram várias semelhanças, este tornou-se um elemento de peso na maior parte das decisões que se vieram a tomar a partir daí; serviu de comparação à estruturação da cavea, à sua dimensão, à implantação em perfil, entre outras.

A segunda forma de comparação ocorreu com o objectivo de encontrar proporções ou regras que pudessem ser usadas no desenho dos equipamentos de Tongobriga. Exemplo disso, no caso do forum, fo a análise de implantação do templo em diferentes fora. Essa comparação foi essencial para propor a proporção de implantação do templo no forum de Tongobriga ${ }^{19}$
No caso do teatro, para o apontamento de uma configuração do pórtico postscaena, recorremos a diversos exemplos para entender certas proporções e, assim, propor o seu delineamento.

A reconstituição do centro cívico de Tongobriga resulta então do conjunto de ensaios realizados. Estes demonstram o rigor das soluções romanas ${ }^{20}$, assim como a grande capacidade que possuíam na adaptação dos seus cânones aos lugares onde chegavam. Em Tongobriga isso é bastante patente, sobretudo devido à topografia local, pois esta não terá facilitado a tarefa.

Este projecto de investigação constitui um conjunto de elementos que poderão servir de contributo para futuras investigações acerca de Tongobriga. Em primeiro lugar, para a Estação Arqueológica do Freixo, que dispõe, assim, de novos elementos e novas ideias a serem desenvolvidos e/ou confirmados em sondagem arqueológica.

Em certas matérias, dispõe de novas ferramentas que podem ser desenvolvidas. A organização da cidade de Tongobriga segundo uma quadrícula actus, por exemplo, constitui uma ferramenta que auxiliará certamente em novas investigações, assim como em futuras sondagens.

Em qualquer um dos equipamentos estudados propomos reconstituições que necessitam de comprovação arqueológica. Cada um dos equipamentos (forum, teatro, anfiteatro) apresenta ideias novas, que permitem ver o centro cívico de forma mais completa (ver: Des. 2.02; Des. 2.03).

Há certamente dúvidas que ainda persistem, mas sem a confirmação em sondagem não são susceptíveis de se esclarecer. Uma dessas dúvidas relaciona-se com a identificação de indícios, a que atribuímos a localização do anfiteatro ${ }^{21}$.

Ao longo da investigação delineámos, por vezes, mais de uma hipótese de reconstituição de certos elementos; ou apenas recorremos a uma para a reconstituição final. A razão pela qual não omitimos as restantes foi por considerarmos este trabalho também um contributo para futuras investigações; ou seja, apesar de termos encontrado elementos que favorecem sempre uma das hipóteses, tal não exclui as

${ }^{20}$ Durante a investigação, defrontámo-nos com algumas irregularidades que não correspondiam à grelha actus, o que nos causou algumas dúvidas sobre a sua aplicação;
até ao momento em que nos apercebemos de que a implantação do desenho do forum no levantamento aerofotogramétrico estava errada. Após a correç̧̃̃o, deixaram de ocorrer irregularidades. ${ }^{21}$ Ver pp. 154-157. 
demais, não utilizadas, que poderão ganhar valor com novos indícios que surjam em sondagens futuras.

Tal como referido no início desta publicação, a investigação é realizada do ponto de vista do arquitecto. Este é um dado importante, pois a forma como o arquitecto vê a ruína é diferente de como é vista por um arqueólogo, tal como é diferente de como é vista por um pintor, um historiador ou um poeta.

Essa diferença remete para a forma como o desenho é usado pelo arquitecto. $O$ desenho torna-se no instrumento operativo do arquitecto, funcionando como a extensão do seu pensamento (pensar é desenhar); um desenho que possui as suas próprias regras, e que o torna numa ferramenta própria da disciplina arquitectónica.

"Fragmento de uma arquitectura do passado, a ruína denuncia, simultaneamente, uma presença e uma ausência. A sua inteligibilidade é, antes de mais, um convite à reconstituição" ${ }^{\prime \prime 2}$.

Este convite é especialmente atractivo para o arquitecto, sobretudo tratando-se de um fragmento do período romano; pois, como é "(...) construída segundo cânones tipológicos e construtivos largamente difundidos, a arquitectura romana sobrevivente fornece as pistas para a interpretação de novos fragmentos, comparando os vestígios existentes e a datação proposta com exemplos conhecidos $^{\prime \prime 23}$.

Por vezes, o desejo de complementar a ruína representa uma atitude arriscada; a procura de uma relação formal e construtiva entre os vestígios existentes e o restante ausente apoia-se numa busca que parte de suposições/hipóteses. Estas, por sua vez, situam-se e desenvolvem-se entre uma vertente do pensamento lógico e uma vertente do pensamento intuitivo.

No entanto, é desta forma que essa atitude procura dar resposta a um determinado problema; e que geralmente "(...) resulta em desenhos que ampliam o conhecimento dos monumentos, ou em obras que o procuram tornar mais inteligível, enriquecendo a his tória e a arqueologia, bem como a arquitectura, como teoria e como prática" ${ }^{\prime 24}$.

${ }^{22}$ Pedro Alarcão, "Seminário internacional de arquitectura e arqueologia - Interpretar a ruína" (texto de apresentação do enquadramento temático).
Assim, o convite à reconstrução/reconstituição da ruína, por parte do arquitecto, resulta na identificação de novos elementos e novas ideias, que levam o arqueólogo a reexaminar os vestígios escavados, em função das novas leituras. O que demonstra, claramente, a vantagem da interdisciplinaridade entre estes dois campos: a arquitectura e a arqueologia. 
Bibliografia GERAL:

Livros:

ADAM, Jean-Pierre. La constrution Romaine: matériaux et techniques, 2.a ed. Paris: Grands Manuels Picard, 1989 (1.a ed. 1984).

ADAM, Jean-Pierre. La Construcción Romana. Materiales y Técnicas, trad. por Cristina Colinas Carbajo. León: Editorial de los Oficios, 2002.

ALBERTI, Leon Battista. L'Architettura [De Re Aedificatoria], trad. it. Giovanni Orlandi. Milão: Edizioni II Polifilo, 1966 (1.a ed. 1485).

ALBERTI, Leon Battista. De Re Aedificatoria: Leon Battista Alberti. trad. esp. Javier Fresnillo Núñez. Madrid: Ediciones Akal, S.A., 1991 (1.a ed. 1485).

ALBERTI, Leon Battista. On the Art of Building in Ten Books [De Re Aedificatoria], trad. ing. Joseph Rykwert, Neil Leach e Robert, Tavenor. Londres: The MIT Press, 1996 (1.a ed. 1485).

ALBERTI, Leon Battista. L'art d'édifier [De Re Aedificatoria], trad. fr. de Pierre Caye e Françoise Choay, Source du savoir. Paris: Éditions du Seuil, 2004 (1.a ed. 1485).

ALARCÃO, Jorge. O Domínio Romano em Portugal. Lisboa: Europa-América, 1988

ALARCÃO e Silva, Pedro Duarte Santos de. Construir na ruína: a propósito da cidade romanizada de Conimbriga. Porto: Faup, 2009.

BAPTISTA, Luís Santiago. Revista Arquitectura e Arte n.o 82/83 - Acções Patrimoniais. Amadora: Artes Gráficas S. A., 2010.

BENEVOLO, Leonardo. Diseño de ciudad - 2. El Arte y la ciudad antigua. México: Ediciones Gustavo Gili, 1979.

BENEVOLO, Leonardo. Introdução à Arquitectura (III-A Arquitectura Romana), trad. Maria Manuela Ribeiro. Lisboa: Ed. 70, 1991.

CHOAY, Françoise. L’Alegorie du Patrimoine. Paris: Seuil, 1992.

CHOAY, Françoise. A alegoria do património, trad. Teresa Castro. Lisboa: Edições 70, 2000.

COSTA, Aníbal. A intervenção no património: práticas de conservação e reabilitação. Porto: FEUP, 2005.

COULON, Gérard; GOLVIN, Jean-Claude. Voyage en Gaule romaine. Paris: Edition Errance, 2006

\section{BIBLIOGRAFIA}


GROS, Pierre. L'Architecture Romaine du début du IIle siècle av. J.C. à la fin du Haute-Empire - Les Monuments Publics, vol. I, Gérard Nicolini (coord.), Col. "Les Manuels d'Art et d'Archéologie Antiques". Paris: Picard Éditeur, 1996.

JORGE, Vítor Oliveira. Conservar para quê? Porto: FLUP, 2005.

LARA ORTEGA, Salvador. El teatro romano de Sagunto: génisis y construcción. Valencia: Servicio de Publicaciones. Universidad Politécnica, 1991.

LINAZASORO, José Ignacio. Evocando la ruina: sombras y texturas: centro cultural en Lavapiés. Madrid: GMUAM, 2004.

LOPES, Flávio. Património arquitectónico e arqueológico: cartas, recomendações e convenções internacionais. Lisboa: Livros Horizonte, 2004.

MARTINS, Maria Manuela. "Urbanismo e Arquitectura em Bracara Augusta. Balanço dos contributos da Arqueologia Urbana”. In Simulacra Romae, 2008.

MARTINS, Maria Manuela; FONTES, Luís. “Bracara Augusta. Balanço de 30 anos de investigação arqueológica na capital da Galécia Romana". In Simulacra Romae II, 2010.

REDDÉ, Michel; GOLVIN, Jean-Claude. Voyages sur la Méditerrané romaine. Paris: Éditions Errance, 2005

RIEGL, Alois. Le culte moderne des monuments, son essence, sa genèse. Paris: Le Seuil, 1903.

RIEGL, Alois. El culto moderno de los monumentos: caracteres y origen, trad. por Ana Pérez López. Madrid: Visor, 1987.

STIERLIN, Henri. O Império Romano - Dos Etruscus ao declínio do Imperio Romano, trad. Maria Filomena Duarte. Koln: Benedikt Taschen, 1997.

USTÁRROZ, Alberto. La Lécción de las Ruinas: Presencia del pensamiento grego y romano en la arquitectura. Barcelona: Fundación Caja de Arquitectos (Col. Arquíthesis, núm. 1), 1997.

VITRÚVIO, Marco. Les Dix Livres d'Architecture, trad. fr. Claude Perrault, Andrés Dalmas (apres.). Paris: Editions Errance, 1986 (1. ed. 1486).

VITRÚVIO, Marco. Los Diez Libros de Arquitectura, trad. esp. Joseph Ortíz Sanz. Barcelona: Biblioteca Alta Fulla, 1993 (1.a ed. 1486).

VITRÚVIO, Marco. Os dez livros de Arquitectura de Vitruvio, trad. port. Maria Helena Rua. Lisboa: Decist, 1998 (1.. ed. 1486).

VITRÚVIO, Marco. Vitruvius, Ten Books on Architecture, trad. ing. Ingrid D. Rowland e Thomas Noble Howe (eds.). Cambridge: Cambridge University Press, 1999 (1.a ed. 1486).

VITRÚVIO, Marco. Tratado de arquitectura, trad. port. M. Justino Maciel. Lisboa: IST-Press, 2006 (1.a ed. 1486).

\section{Sítios consultados:}

http://academicearth.org/courses/roman-architecture

http://video.google.com/videoplay?doid=3835180210372211248\#»

http://www.imdb.com/title/tt0796311/

www.museuteatroromano.pt

http://pt.wikipedia.org/wiki/teatro_romano

http://www.portugalromano.com/category/cidades-romanas-em-portugal/

http://www.ancientlibrary.com/bookshelf.php

http://www.ancientlibrary.com/smith-dgra/0020.html

http://bib.cervantesvirtual.com/portal/simulacraromae/

http://bib.cervantesvirtual.com/portal/simulacraromae/bracara/Flash41/ main4.html

http://www.spanisharts.com/arquitectura/i_roma_urbano.htm Ancient Mysteries: Ostia - The Sunken City (1/3)

http://www.dailymotion.com/video/xg38k5_ancient-mysteries-ostia-the-sunken-city-1-3_shortfilms

http://www.dailymotion.com/video/xg38ka_ancient-mysteries-ostia-the-sunken-city-2-3_shortfilms

http://www.dailymotion.com/video/xg38kf_ancient-mysteries-ostia-the-sunken-city-3-3_shortfilms

http://www.monumentos.pt/Site/APP_PagesUser/SIPA.aspx?id=3860

http://www.monumentos.pt/Site/APP_PagesUser/SIPA.aspx?id=4930 http://academicearth.org/courses/roman-architecture 


\section{Bibliografia de TONGOBRIGA}

Livros:

DIAS, Lino Augusto Tavares. Tongobriga. Tese de doutoramento apresentada à Faculdade de Letras da Universidade do Porto, Porto: [Edição do Autor], 1995.

DIAS, Lino Augusto Tavares. Cerâmica comum romana em Tongobriga. Porto: [Edição do Autor], 1995.

DIAS, Lino Augusto Tavares. Tongobriga. Lisboa: IPPAR, 1997.

DIAS, Lino Augusto Tavares. Tongobriga - Guia de Visita. Impressão Publigraff 1999.

DIAS, Lino Augusto Tavares. Área arqueológica do Freixo - Futuro?. (...), 2000

DIAS, Lino Augusto Tavares. “A urbanização do Noroeste peninsular: O caso de Tongobriga”. In Actas da Mesa Redonda - Emergência e Desenvolvimento das Cidades Romanas no Norte da Península Ibérica. Porto, 1999.

DIAS, Lino Augusto Tavares. Novos contributos sobre o Forum de Tongobriga Porto: Universidade do Porto. Faculdade de Letras, 1999.

DIAS, Lino Augusto Tavares; SOARES, Rosa. Tongobriga. Contributo Documental. Porto, 1999

DIAS, Lino Augusto Tavares. Tongobriga. Breves Reflexões. Porto: IPPAR. 2003.

DIAS, Lino Augusto Tavares. Povoamento romano na Bacia do Douro: A criação de cidade. Tongobriga e o Territorium. Valladolid, 2010, pp. 21-40.

DIAS, Lino Augusto Tavares. "Gestão Integrada da Área Arqueológica do Freixo. Tongobriga: contributo para abordagem à estratégia de intervenção entre 1980 e 2010". Al-madan. Almada. II Série, n.o 16 (2008), pp. 82-91.

DIAS, Lino Augusto Tavares. Contributos de Rocha Peixoto para a leitura contemporânea de unidades de paisagem cultural do Douro Verde. Póvoa de Varzim: Câmara Municipal da Póvoa de Varzim, 2009.

DIAS, Lino Augusto Tavares. "Urbanization and architecture on the outskirts of the Roman Empire". In Roma y las provincias: modelo y difusión. Trinidad Nogales Isabel Rodà editoras, Volume 2, 2011, pp. 707-713.

DIAS, Lino Augusto Tavares. "O momento e a forma de construir uma cidade no noroeste da Hispânia, periferia do Império romano e fronteira atlântica". Revista da Faculdade de Letras Ciências e Técnicas do Património - Universidade do Porto, n.. XII. Porto, 2013, pp. 113-126.

LIMA, A. de Carvalho. Os mosaicos da igreja de Santa Maria do Freixo e a ecclesia de Tongobriga, paróquia da diocese portucalense no século VI. Caderno de Tongobriga, DRCN/EAF. Freixo, 2012.
SOARES, Rosa Maria. Area arqueológica do Freixo: Marcos de Canaveses Marco de Canaveses: Câmara Municipal de Marco de Canaveses, 1985.

SILVA, João Belmiro Pinto da. Marco de Canaveses - Um olhar sobre o património.... Paços de Ferreira: Anégia, 2000.

Sítios consultados:

www.tongobriga.net

www.tongobriga.com.sapo.pt

www.monumentos.pt

http://proteus.brown.edu/tongobrigaexcavations/Home

http://www.maraoonline.com/MARAO/MARAO_online/6C333A7D-F05D44CB-950A-64C184FCBF9D.html

http://tv1.rtp.pt/noticias/?article=168833\&visual=3\&layout=10

http://www.monumentos.pt/Site/APP_PagesUser/SIPA.aspx?id=3860

http://www.monumentos.pt/Site/APP_PagesUser/SIPA.aspx?id=4930 
Actus - Área equivalente a 120 por 120 pés. Seria o espaço trabalhado por uma junta de bois durante meio-dia (manhã ou tarde).

Aditus - Corredor subterrâneo.

Aedes - Designação do templo enquanto construção, lugar onde o deus reside.

Ala - Corpo de um edifício cuja cobertura é independente do resto da construção; corredor determinado por uma colunata.

Alveleus - Tanque rectangular para banho de água quente; piscina.

Apodyterium - Sala de dispor e vestir, antes e depois do banho. Podia comportar a função de vestiário, sendo para isso dotada de nichos.

Atrium - Sala que normalmente se seguia ao vestíbulo, dotada de abertura zenital para recolha das águas pluviais.

Balteus - Murete que separa a cavea da orchestra.

Caldarium - Sala aquecida a partir de um hipocausto e dotada de uma ou mais piscinas.

Cardo - Via Norte-Sul que cruzava perpendicularmente com o decumanus, conduzindo da entrada principal à outra extremidade do acampamento permanente. $O$ esquema aplicou-se às cidades.

Cavea - Área semicircular, composta por assentos, reservada aos espectadores.

Cella - Parte do templo que albergava a(s) estátua(s) do(s) deus(es). Quando seguida de um designativo, a palavra toma diferentes significados como sala, armazém, quarto pequeno, etc.

Cenatio - Sala de banquete ou de recepção.

Civitas - Cidade que administrava um territorium

Compluvium - Espaço aberto central na cobertura do átrio.

Conventus - Subdivisão de província.

Crypta - Sala ou corredor subterrâneo.

Cubiculum - Quarto de dormir. No plural cubicula.

Cubicus - Côvado.

Cuneus - Sector em que se divide a cavea.

Decumanus - Via Este-Oeste que cruzava com o cardo.

Digitus - Dedo

Domus - Casa de habitação de prestigio, de uma só família. 
Exeadra - Espaço quadrangular, por vezes semicircular, reentrante numa parede, francamente aberto e geralmente dotado de banco(s) encostado(s) à parede.

Fauce - Corredor, em especial o que conduz ao átrio e o que liga o átrio ao peristilo.

Frigidarium - Sala destinada a banhos frios.

Frons scaenae - Muro de fecha a cena, formando um cenário permanent construído por colunas, nichos e três portas.

Groma - Instrumento romano usado na medição topográfica.

Hospitalium - Quartos de hóspedes, numa casa rica.

Ima cavea - Sector mais baixo da cavea.

Impluvium - Tanque para recolha de águas pluviais no centro do atrium.

Insula - Bloco residencial inteiramente contornado por ruas.

Media cavea - Sector intermédio da cavea

Natatio - Piscina de água fria cujas dimensões permitiam nadar.

Oppidum - Cidade muralhada.

Orchestra - Zona plana, de forma semicircular, na base da cavea, perto da cena, destinada aos notáveis.

Palaestra - Originalmente, era a parte do ginásio onde os jovens se treinavam na luta. Os arqueólogos usam o termo em sentido lato, designando todo ginásio.

Palmus - Palmo. Medida tirada com os quatro dedos juntos, excluído o polegar

Parascenium - Vestíbulo de acesso a casa; uma das duas extremidades do pulpitum. Também se pode designar por vesura.

Paraskenia - As duas grandes salas contíguas ao parascaenium, nas duas extremidades do pulpitum.

Passus - Passo.

Peristilum - Colunata em torno de um pátio.

Pes - Pé

Podium - Plataforma sobre a qual é construído um edifício, no seu todo ou em parte.

Postscaenium - Área localizada atrás da cena, onde podiam situar-se várias dependências.
Praecinctio - Corredor de circulação servindo os maeniana de um teatro.

Praefurnium - Boca de fornalha. Surge tomado em sentido de hypocaustum.

Proscaenium - Frente do pulpitum de um teatro.

Pulpitum - Estado elevado acima da orchestra, delimitando a cena. Frequentemente, era decorado com um friso e nichos.

Scaena - Cena; palco.

Scalaria - Escadas que asseguravam a circulação vertical entre as bancadas.

Sacrarium - Compartimento de um templo ou de um pretório onde se guardavam os objectos destinados ao culto. Numa casa, era o local dedicado aos deuses domésticos.

Summa cavea - Sector mais elevado da cavea.

Taberna-Loja.

Tablinum - Espaço situado entre as alae do atrium, cuja função foi mudando ao longo do tempo, embora mantendo a sua importância.

Témenos - Espaço sagrado que rodeia o templo.

Tepidarium - Sala que, do ponto de vista técnico, servia de tampão entre as zonas frias e as zonas quentes das termas. Podia funcionar como unctorium.

Territorium - Porção de terra dependente da mesma unidade política.

Unctorium - Sala onde se aplicavam os óleos para as massagens.

Urbs - Cidade. Quando muralhada, a cidade tomava o nome de oppidum. Na prática, dado que quase todas as cidades são muralhadas, os nomes equivalem-se.

Valva regia - Porta principal do corpo cénico sobre o palco.

Valva hospitalium - Porta(s) secundária(s) laterai(s) do corpo cénico sobre o palco.

Valarium - Cobertura de tela estendida sobre um teatro ou um anfiteatro.

Vesura - Vestíbulo. No teatro romano as versurae abriam para o palco por uma porta que Vitrúvio chama de itinera versurarum.

Vestibulum - Compartimento destinado a receber as pessoas à entrada da casa. Espaço que precede o naos ou que serve para controlar a fuga de ar quente, nas termas.

Vomitorium - Abertura(s) na cavea permitindo aos espectadores aceder-lhe através de um corredor subterrâneo. 


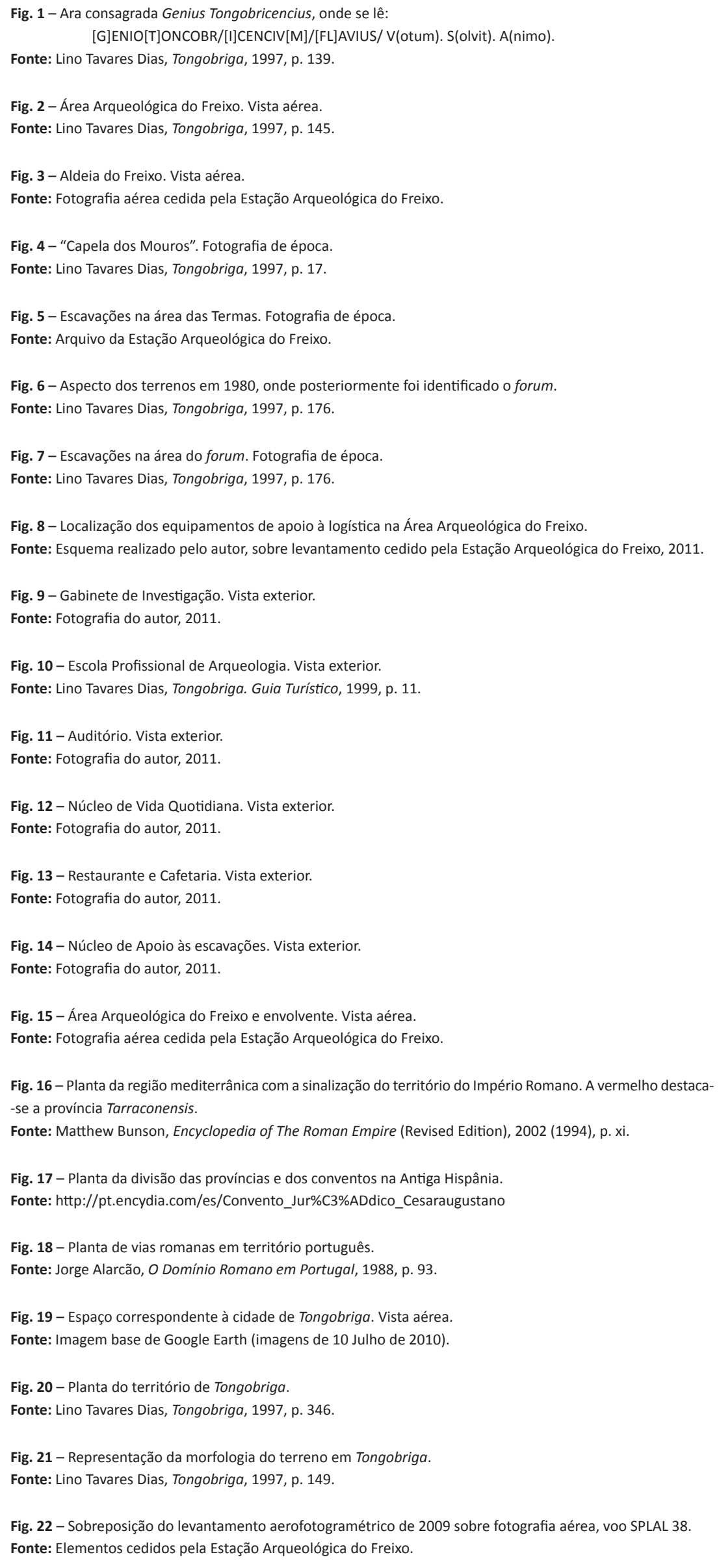


Fig. 23 - Ilustraçăo da Cidade Romana de Bibilils, por Jean-Claude Golvin. Nesta imagem é relevante a atençăa

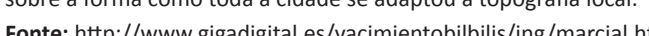

Fig. 24 - llustração da cidade de Tarraco, por F. Terrals.

fonte: Pierre Gros, LArchitecture Romaine du début du llle siècle av. J.. à la fin du Haute-Empire - Les Mon

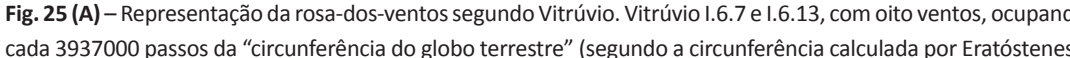
Fonte: Desenho de Thomas Noble Howe, Vitruivio. Tratadodo de Arquitectura (Tradução de Justino Maciele), 2006, p. 61 Fig. 25 (B) - Representação da rosa-dos-ventos segundo Vitrúvio. Vitrúvio 1.6.10, com ventos adicionais interFonte: Desenho de Thomas Noble Howe, Vitrúvio. Tratado de Arquitectura (Traduşão de Justino Maciel), 2006 ,
p. 61.

Fig. 26 - Planta da zona escavada na Necrópole do séc. IV em 1994

Fig. 27 - Necrópole do sée. IV. Aspecto de uma zona escavada.

Fonte: Lino Tavares Dias, Tongobriga, 1997, p. 210 .

Fig. 28 - Urbanismo, a organização e percurso da cidade sobre fotografia aérea.

Fontel Lino Tavares Dias, Tongobriga, 1997, pp. 32-33.

Fig. 29 - Esquemas da Muralh

Fonte: Esquema realizado pelo autor, 2011

Fig. 30 - Afloramento granitico que terá servido de suporte a um troşo de muralha. Limite norte, junto ao ponto Fonte: Fotografia do autor, 2011.

Fig. 31 - Troço de muralla poente. Junto do conjunto habitacional.

Fie $32-$ Toso de

Fonte: Fotografaia do autor, 2011.

Fig. 33 - Passagem que dava acesso à cidade de Tongobriga, pelo lado norte.

Fonte: Fotografia do autor, 2011

Fig. 34 - Troço de muralha. Junto ao edificio oval, lado nascente.

Fonte: Fotografia do autor, 2011.

Fig. 35 - Troço de muralha. Junto às Termas, lado nascente.

Fonte: Fotografia do autor, 2011

Fig. 36 - Muro que se julga ter pertencido à muralha da 2.? fase. Norte do Teatro.

Fonte: Fotografia do autor, 201

Fig. 37 - Escarpa e muro onde terá passado a muralha da 2.. fase. Oeste do forum

Fonte: Fotografiia aérea cedida pela Estação Arqueológica do Freix

Fig. 38 - Passagem que dava acesso à porta sul da muralha, na segunda fase da cidade. Panorâmica. Fonte: Fotografia do autor, 2011

Fig. 39 - Passagem que dava acesso à porta sul da muralla, na segunda fase da cidade. Vista de frente.
Fonte: Fotografia do autor, 2011 .

Fig. 40 - Painel expositivo na recepção da Área Arqueológica do Freixo, em que se demonstra uma hipótese mais abrangente da cidade (esta abarcaria uma maior área da encosta poente).

Fig. 41 - llustraçăo de um espaço termal romano. Pompeianas no Frigidarium, pintado por Pedro Weingartne

Fonte: http://thearcheology.files.wordpress.com/2010/06/pompeianas-no-frigidarium-pintado-por-pedrorne-1897.jpg

Fig. 42 (A/B) - Planta e perfis do balneário Castrejo.

Fonte: Desenhos de Lino Tavares Dias, Tongobriga, 1997, anexos.

Fig. 42 (C) - Aspecto da entrada, sala dos bancos laterais e parede com decoraçăo aplicada (pedra formosa). Fonte: Lino Tavares Dias, Tongobriga, 1997, p. 159
Fig. 43 - Planta e perfis dos vestigios das Termas.

Termabriga, 1997, anexos.

Fonte: Fotografia do autor, 2011 .

Fig. 45 - Termas. Espaço dos banhos tépidos (tepidarium

onte: Fotografia do autor, 2011.

Fig. 46 - Termas, espaço do hipocausto, onde é possivel ver os colunelos construídos em tijolo.

Fonte: Lino Tavares Dias, Tongobriga, 1997, p. 173.

Fig. 47 - Termas, espaço dos banhos quentes (caldarium

Fonte: Fotografia do autor, 2011.

Fig. 48 - Termas. Ilustraç̃o de Thomas Noble Howe, que demonstra como a criadagem alimentava a fogueira,

para o aquecimento das águas.

Fonte: :

Fig. 49 - Esquema das Termas 1.

Fonte: Lino Tavares Dias, Tongobriga, 1997, p. 157.

ig. 50 - Esquema das Termas

Fonte: Lino Tavares Dias, Tongobriga, 1997, p. 157.

Fig. 51 - Esquema das Termas III.

Fonte: Lino Tavares Dias, Tongobriga, 1997, p. 157

Fig. 52 - Espaço da Natatio. Panorâmica.
Fonte: Fotografia do autor, 2011.

Fig. 53 - Esquema tridimensional das Termas I, complexo termal

Fig. 54 - Esquema tridimensional das Termas II, complexo termal.

Fonte: Lino Tavares Dias, Tongobriga, 1997, p. 153.

Fig. 55 - Integração do forum na topografia. Este situa-se a sul das áreas habitacionais, numa baixa da cadeia

Fonte: Fotografia aérea cedida pela Estação Arqueológica do Freixo.

Fig. 56 - Planta do forum.
Fonte: Planta CAD fornecida pela Estação Arqueológica do Freixo.

Fig. 57 - Forum. Vista panorâmica no sentido sudoeste.

fonte: Fotografia do autor, 2011.

Fig. 58 - Forum. Vista panorarmica no sentido nordeste.

Fonte: Fotografia do autor, 2011.

Fig. 59 - Plataforma comercial. Vista no sentido nascente-poente.

k.com/photo.php?fbid=212977292066 6898.set=a.212974962066922.59342.10000063326003048\&type=18theater).

Fig. 60 - Limite norte do forum.
Fonte: Fotografia do autor, 2011.

fig. 61 (A) - Abside nascente do muro norte.

Fonte: Lino Tavares Dias, Tongobriga, 1997, p. 179 ,

ig. 61 (B) - Abside quadrada central do muro norte.

Fonte: Fotografia do autor, 2011

Fig. 61 (c) - Abside poente do muro norte.

Fonte: Fotografia de João Mayor em Tongobriga. Breves Reffexōes, 2003, p. 44

19. 62 - Circo. Esquema de localizaçăo face à cidade.

Fonte: Esquema realizado pelo autor, 2011.

Fig. 63 - Localizacão do teatro. Vista aérea, sentido 
Fig. 64 - Posição do teatro, junto ao forum.

de Visita, 1999, p. 10

sentido sul

Fig. 66 - Teatro. Vista panorâmica no sentido norte.

Ag. 67 - Aspecto do espaço o onde se identificou as estruturas do eventual circo. Vista aérea no sentido norte. Fonte: Lino Tavares Dias, Tongobriga, 1997, p. 148

Fig. 68 - Circo. Localização em vista google.

Fonte: Imagem Google Earth (imagens de 10 Juho de 2010 )

Fig. 69 - Bassilica Paleocristã̃. Esquema da aplicação proporcional, segundo um dos preceitos vitruvianos.

Fonte: Esquema realizado pelo autor, 2011

Fig. 70 - Igreja de Sta. Maria do Freixo, onde foram descobertos os vestigios da Basilica Paleocristã. Vista exterior no sentido nascente, e, a sombreado vermelho, o delineamento das fundaçöes da Basilica.
Fonte: Fotografia do autor, 2011 .

Fig. 71 - Mosaicos policromados, detectados aquando das sondagens na Igreja de Sta. Maria do Freixo.

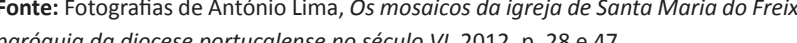

Fig. 72 - Planta e registo das sondagens na área da lgreja de Sta. Maria do Freixo. realizado por António Limal.

Fig. 73 (A) - Uma das situaçōes em que é possivel verificar a sobreposiç̧ão destas duas fases de arquitectura na cidade de Tongobriga. Vista (A).

Empire", in Roma y los provincias: modelo y difusión, 2011, p. 709 .

Fig. 73 (B) - Uma das sittuaç̄es em que é possivel verificar a sobreposiçăo destas duas fases de arquitectura na cidade de Tongobriga. Planta (B).

Conges

Fig. 74 (A) - Conjunto habitacional poente. Vista aérea (A).

Fonte: Lino Tavares Dias, Tongobriga. Guia Turistico, 1999, p. 7 .

Fig. 74 (B) - (....) Planta (B).
Fonte: Levantamento fornecido pela Estação Arqueológica do Freixo.

Fig. 75 (A/B) - Conjunto habitacional nascente. Vista (A/B).

: Fotografia do autor, 2011

Fig. 75 (c) - (...) Planta (C).

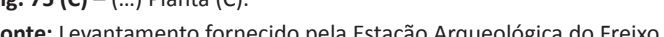

Fig. 76 (A/B) - Vestigios de habitação a sul da Basilica Paleocristã. Vista (A/B).

Fig. 76 (c) - (...) Planta (C).

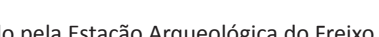

Fig. 77 - Esquema do núcleo habitacional da encosta poente.
Fonte: Esquema

Fig. 78 - Casa do Impluvium.
Fonte: Fotografia do autor, 2011 .

Fig. 79 - Casa do Impluvium. Implúvio com pavimento granitico.

Fonte: Fotografia do autor, 2011.

Fig. 80 - Casa do Impluvium. Vista no sentido poente.

Fig. 81 (A) - Domus itálica. Representação axnométrica.

Fonte:http://www.parlandosparlando.com/view.php/id__598/ingua__/whoisit__

Fig. 81 (B) - Domus itálica. Planta.

Himperiale/abitazioni/abitazioni.htm!
Fig. 82 - Casa do Impluvium. Planta.

Fig. 83 - Desenho de um corte tipo da uma casa romana do tipo itálica. Desenho de David Macaulay.
Fonte: David Macaulay, A cidade Romana, 1980, p. 24 . Fig. 84 - Planta da Casa do Implluvium, com a aplicação das dimensōes proporcionais indicadas por Vitrúvic

\section{II - Centro Cívico Romano de Tongobriga}

Fig. 85 - Figura onde se demonstra uma hipótese de estrutura da zona habitaciona Fonte: Lino Tavares Dias, "A urbanizacăo do Noroeste peninsular: O caso de Tongobriga", in Actas da Mesa
Redonda - Emergenncia e Desenvolvimento das Cidades Romanas no Norte da Peninsula aberica, 1999, p. 103.

Fig. 86 - Aplicação do módulo passus nas Termas

Fontes bino Tovares Disas "Urbanization and architecture on the outskirts of the Roman Empire", in Roma y las provincias: modelo y difusión, 2011, p. 868.

Fig. 87 - Applicaçăo do módulo passus no forum.

Fonte: Lino Tavares Dias, "Urbanization and architecture on the outskirts of the Roman Empire", in Roma y las

Fig. 88 - Esquema passus

Fig. 89 (A) - Bracara Augusta, planta da estruturação pela grelha $150 \times 150$ pés. bitura da evolusã̃o da paisagem urbana, 2008, p. 239.

Fig. 89 (B) - Modelo teérico da malha de Bracara Augusta.

Fonte: Maria Ribeiro, Braga entre a época romana ea
leitura da evoluçacoo da paisagem urbana, 2008, p. 244.

fig. 90 - Estruturaçăo da Área Arqueológica do Freixo pelo quadriculado Actus Quadratus. Planta.

fonte: Desenho realizado pelo autor, 2011.

Fig. $91-$ Esquema de centuria.
Fonte: Esquema realizado pelo autor, 2011.

Fig. 92 - Timgad (Argélia), exemplo de divisão de uma cidade em insulas quadradas

fonte: Leonardo Beniovolo, História da cidade, trad. por Silvia Mazza, 1999, p. 10.

Fig. 93 - Mapa da regiẫo de Imola (Forum Cornelli), atravessada pela Via Emilia, sobre a qual se pode ler no

Fonte: Leonardo Beniovolo, Historiri da ciddade, trad. por Silvia Mazza, 1999, p. 13.

Fig. 94- Estruturação dos vestíios romanos, pelo quadriculado Actus Quadratus.
inte: Desenho realizado pelg autor 2011 .

Fig. Is - Configuraçăo das Termas numa unilade actus quadratus. Esquema.

Fonte: Esquema(des) realizado pelo autor, 201

Fig. 96 - Configuração do forum no quadriculado actus quadratus. Esquema.

Fonte: Esquema(des) realizado pelo autor, 2011

Fig. 97 - Enquadramento das Termas e da cabeceira do forum, com respectivos eixos.

Fonte: Esquema(des) realizado pelo autor, 201

ig. 98 - Organizacão das estruturas do forum segundo o quadriculado actus

Eonte: Esquema(des) realizado pelo autor, 2011.

Hig. 99 - Enquadramento da zona de domus. Esquemas.

Fonte: Esquemaldes) realizado pelo autor, 201

ig. 100 - Segmentos de ruas correspondentes aos eixos do quadriculado actus.

Fonte: Esquema(des) realizado pelo autor, 2011. 
Fig. 101 - Realce das ruas na aldeia Freixo.

Fig. 102 - Segmentos de ruas correspondentes a uma orientação nascente-poente.
Fonte: Esquema(des) realizado pelo autor, 2011.

Fig. 103 - Casas que ladeiam as ruas correspondentes aos eixos do quadriculado.

\section{Fig. 104- Ruas e habitaçăo. Fotogratias
Fonte: Fotografia do autor 2011.}

Fig. 105 - Exemplo 1. Quadricula correspondente ao aquedu

Fig. 106 - Exemplo 2. Quadricula correspondente ass vestigios da zona habitacional nascente.

Fig. 107 - Conjunto de elementos realşados, mais una série de ruas que se orientam a 45 graus.

Fonte: Esquemaldes) realizado pelo autor, 2011 .

Fig. 108 - Planta anterior, onde é possivivel ver a posič̃oo original da rua antes de ter sidd desvian. Fonte: Lino Tavares Dias, "A urbanização do Noroeste peninsular: O caso de Tongobriga", in Actas da Mes .

Fig. 109 - Progressão de uma implantação cadastral com o uso do actus e da jugeurum como unidade de lon-

Fig. 110 - Indicaçăo da rua diagonal que ligaria o centro civico à zona habitacional.

Fig. 111 - Alastramento do quadriculado actus, com dois pontos de origem. Zona habitacional (a), centro Fonte: Esquemaldes) realizado pelo autor, 2011.

Fig. 112 - Perfil do terreno. Ilustração da quebra visual entre o centro civico e a zona habitaciona

Fonte: Esquema(des) realizado pelo autor, 2011

Fig. 113 - Estruturação dos vestigios romanos, no estado actual, pelos dois quadriculados Actus Quadratus Fonte: Desenho realizado pelo autor, 2011.

Fig. 114 - Ampliaçăa, onde e possivel ver o ponto de destasamento do quadriculad.

Fonte: Desenho realizado pelo autor, 2011 .

Fig. 115 - Localização da parcela de terreno correspondente a um actus.

Fonte: Fotografia aérea cedida pela Estação Arqueoóógica do Frèró

Fig. 116 - Conjunto de elementos identiticados, mais a localizaçăo da parcela.

Fonte: Esquemaldes) realizado pelo autor, 2011 .

Fig. 117 - Resumo dos elementos identificados através do uso do quadriculado Actus Quadractus, após des

Fonte: Esquemaldes) realizado pelo autor, 2011

Fig. 118 - Esboço realizado em vistas ao forum com: identificaçăo de espaços de sondagem e de vestiglos.

Fonte: Esboço realizado pelo autor, 2011

Fig. 119 - Grupo de sapatas junto ao muro norte (A).

Fonte: Fotografia do autor, 2011

Fig. 120 - Grupo de sapatas junto à plataforma comercial (B).

Fig. 121 - Sapata junto à entrada das termas (C).

Fonte: Lino Tavares Dias, Tongobriga, anexo.

Fig. 122 - Forum. Enquadramento actus elogica de simetria de colunatas norte e su

Fonte: Desenho realizado pelo autor, 2011 .

Fig. 123 - Área escavada onde é possivel ver a função dos talhes.

Fonte: Fotografia do autor, 2011.
Fig. 124- Talhes no afloramento, canto nordeste do forum.

Fig. 125 - Talhes no afloramento com sapata, junto ao muro norte do forum.

Ig. 126 - Talhes no afloramento, pertencente ao grupo de sapatas su

Fonte: Esbogo realizado pelo autor, 2011.

Fig. 128 - Sapatas de colunas. Recente sondagem.

ig. 129 - Talhes no afloramento. Recente sondagen

Fonte: Fotografia do autor, 2011.

Fig. 130 - Esquema de delineamento dos talhes no espaço do forum

fonte: Esquema realizado pelo autor, 2011 .

g.131-Forum. Enquadramento actus, lobltade simetria de colunnatas norte e sul, e pórticos nascente e poente. Fonte: Desenho realizado pelo autor, 2011 .

Fig. 132 - Talhes no afloramento, canto nordeste do forum.

Fonte: Lino Tavares Dias, Tongobriga, 1997, p. 178.

G. 133 - Apilicąăo do àngulo de $45^{5}$ no canto nordeste do forum

Fonte: Desenho reallzado pelo autor, 2011

Fig. 134 - Unidades comuns de medida. Desenhos de Thomas Noble Howe

Fonte: Desenho de Thomas Noble Howe, Vitrúvio. Tratado de Arquitectura (Traduçãode dustino Maciel), 2006,

Fig. 135 - Forum com enquadramento $1 / 2$ de actus.

Fonte: Desenho realizado pelo autor, 201

Fig. 136 - Forum com enquadramento $1 / 3$ de actus.

Fonte: Desenho realizado pelo autor, 2011

Fig. 137 - Forum com enquadramento $1 / 6$ de actus.

alizado pelo autor, 2011

Fig. 138 - Eixo transversal do forum, relação de larguras entre o muro norte e sul.

Este: Esquema(des) realizado pelo autor, 201

Fig. 139 - Forum com enquadramento e identificaçăo de elementos, segundo as unidade 1/4 de actus.

Fig. 140 - Forum com enquadramento $1 / 8$ de actus.
Fonte: Desenho realizado pelo autor 2011 .

Fig. 141 - Forum com enquadramento e identificasăo de elementos, segundo as uma repetição em 5 passsus.
fonte: Desenho realizado pelo autor, 2011 .

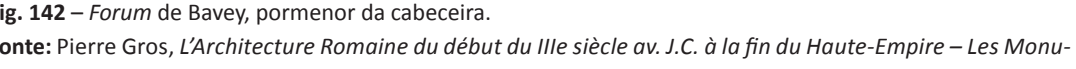
ments Publics, vol. I, 1996, p. 224.

Fig. 143 - Identificaçăo da problemática no canto nordeste do forum, com o apontamento das duas soluçāes Fonte: Esquema realizado pelo autor, 2011 Fonte: Desenho realizado pelo autor, 2011

Fig. 145 - Hipótese de um terceiro portrico, e a duplicação de colunas em relação ò segunda. Fonte: Desenho realizado pelo autor, 2011

Fig. 146 - Plano de reconstituição do ângulo meridional, do forum de César em Roma, segundo Ch. Morselli et E. Tortorici. ments Publics, vol. I, 1996, p. 2.213. 
Fig. 147 - Limite norte da agora/forum de Smyrne, na Turquia, onde se situa a basilica. Reconstituiçăo segundo
J.B. Ward Perkins. J.-Bonte: Perd Perre Gros, LArchitecture Romaine du début du llle siècle av. J.C. à la fin du Haute-Empire - Les Monu Fonte: Perre Gros, LArchitecture
ments Publics, vol. I, 1996, p. 247.

Fig. 148 - Cavidades sobre os talhes no afloramento, canto nordeste do forum

Fonte: Lino Tawes Dibs, Tongobriga, 1997, p. 178.

Fig. 149 - Hipótese da praca, de acordo com o espaço deixado pela aplicação de $1 / 4$ de actus no forum.
Fonte: Desenho realizado pelo autor, 2011 .

Fig. 150 - Hipótese da praşa, de acordo com o espaço deixado pela aplicação de 1/3 de actus no forum.

Fig. 151 - Combinação das hipóteses de praça, tendo em conta a disposição dos talhes no afforamento granítico. Fonte: Desenho realizado pelo autor, 2011.

Fig. 152 - Illustraçăo do forum de Ampurias, segundo E. Sanmartie colaboradores.

Fonte: Pierre Gros, L'Architecture Romaine du début du Illle siècle evv. J.C. à la fin du Haute-Empire - Les Monu

Fig. 153 - Forum de Conimbriga

Corte transversal com indicacăo proporcional do templo em relação ao espaço livere.

Fig. 154 - Illustraçăo do forum Flaviano de Conimbriga, segundo R. Etienne e J.C.C. Golvin. Fonte: Pierre Gros, LArchitecture Romaine du début du IIlle siècle av. J.C. à la fin du Haute-Empire - Les Monuments Publics, vol. I, 1996, p. 17

Fig. 155 - Conjunto de pedras que terão pertencido ao templo.

Fonte: Fotografia do autor, 2011 .

Fig. 156 - Espaço religioso, onde o templo se encontrava

Fonte: Fotografia do autor, 201

Fig. 157 - Aplicąão do principio de um terço para a largura do templo no forum de Tongobriga.

Fonte: Desenho realizado pelo autor, 2011.

Fig. 158 (A) - Outros exemplos onde se verificou o principio de um terço de largura para o templo tendo em conta o espaço livere. Forum de Augusto.

Fonte: Pierre Gros, LAArchitecture Romaine du début du IIIle siècle avv J.C. à la fin du Haute-Empire - Les Monu-

Fig. 158 (B) - (...) forum de Ampúrias.

Fonte: Pierre Gros, LArchitecture Romaine du début du llle siècle av. J... à la fin du Haute-Empire - Les Monu-

Fig. 158 (c) - (...) forum de clúnia.

Fonte: Pierre Gros, L'Architecture Romaine du début du IIIle siècle av. J.C. à la fin du Haute-Empire - Les Monu

ments Publics, vol. I, 1996, p. 223.

Fig. 158 (D) - (....) forum de Itálica. Fonte: Pierre Gros, 'LArchitecture Ro
ments Publics, vol. I, 1996, p. 184.

Fig. 158 (E) - (...) forum de Feurs.

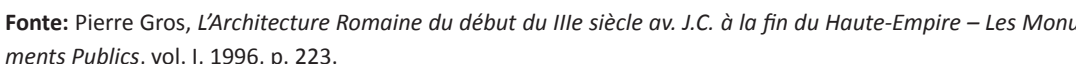

Fig. 158 (F) - (...) forum de Bave,

ments Publics, vol, 1996, 224 .

Fig. 159 - Proposta de reconstituição do forrum de Tongobriga.
Fonte: Desenho realizado pelo autor 2011 .

Fonte: Desenho realizado pelo autor, 2011.

Fig. 160 - Espaço do centro civico, fotografia aérea.

Dias, Tongobriga. Guia de Visita, 1999, p. 3.

Fig. 161 - Aspecto do espaço onde o teatro foi identificado, na encosta poente, junto ao forum.

Fonte: Lino Tavares Dias, Tongobriga, 1997, p. 147.

Fig. 162 - Teatro. Vistas panorâmicas: $(A / B / C$

ografias do autor, 2011.
Fig. 163 - Vestigios na zona do teatro. Planta.

Arqueológica do freixo.

Fig. 164 - Aspecto da zona onde se realizaram sondagens,
fonte: Fotorgatias do autor. 2011 .

Fig. 165 - Modelo virtual da área do teatro (permite visualizar o espaço do teatro sem a arborização)

Finte: Modelo virtual realizado pelo autor, 2011

Fig. 166 - Vestígios arqueológicos. Conjunto de drenos (A). Imagem do dreno (B).

Fonte: Fotografias do autor, 2011.

Fig. 166 - Vestigios arqueológicos. Perfil esbocadodo do dreno (C).

Fig. 167 - Passos de procura do traçado do teatro
Fonte: Esquemas realizados pelo autor, 2011.

Fig. 168 - Passos de procura do traçado do teatro (continuação).

Fig. 169 - Traçado proposto para a teatro
Fonte: Desenho realizado pelo autor, 2011 .

Fig. 170 (A) - Teatros à mesma escala. Teatro de Tongobriga.

Fig. 170 (B) - (...) Teatro de Acinipo.

Fonte: Pierre Gros, LArchitecture Romaine du début du Ille siècle av. JC. à la fin du Haute-Empire - Les Monu-

ments Publics, vol. I, 1996, p. 290.

Fig. 170 (c) - (...) Teatro de Apamea.
fonte: Pierre Gros, L'Architecture Romaine du début du IIle siecle av J.C. à la fin du Haute-Empire - Les Monuments Publics, vol. I, 1996, p. 305 .

Fig. 170 (D) - (...) Teatro de Naples.

Fonte: Pierre Gros, LA'Achitecture Romaine du début du IIle siècle av J.... à la fin du Haute-Empire - Les Monu-

Fig. 170 (E) - (...) Teatro de Cartagena.
Fonte: http://www.spanisharts.com/arquitectura/imagenes/roma/cartagena_teatro.htm|

Fig. 170 (F) - (...) Teatro de Óstia.

Fonte: Pierre Gros, LArchitecture Romaine du début du IIle siècle av. J.C. à la fin du Haute-Empire - Les Monu-

(iig $170(6)-()$

Fonte: Pierre Gros, LAarchitecture Romaine du début du llle siècle av. J.C. à la fin du Haute-Empire - Les MonuFonte: Pierre Gros, Larchitecture Po.

Fig. $170(\mathrm{H})-(. .$.$) Teatro de Clúnia.$

Fonte: Pierre Gros, LAarchitecture Romaine du début du Ille siècle av. JC. à la fin du Haute-Empire - Les Monu-

ments Publics, vol.1, I, 1996, p. 294

Fig. 170 (I) - (...) Teatro de Saepium.

Fonte: Pierre Gros, L'Architecture R.

Fig. 170 (J) - (...) Teatro de Mérida. ments Publics, vol. I, 1996, p. 292

Fig. $170(\mathrm{~K})$ - (...) Teatro de Orange.

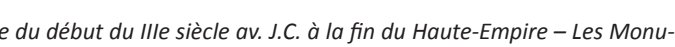
ments Publics, vol. I, 1996, p. 272

Fig. 170 (L) - (...) Teatro de Lepis Magna. Fonte: Pierre Gros, L'Architecture
ments Publics, vol. I, 1996, p. 293.

Fig. 170 (M) - (...) Teatro de Aspendos.

Daine du début du Ille siècle av. J.c. à la fin du Haute-Empire - Les Monuments Publics, vol. I, 1996, p. 304. 
Fig. 170 (N) - (...) Teatro de Bracara Augusta.

ggalhăes, "A construcuăo do teatro romano de tivas, CITCEM, LAMOP, UAUM, Braga, 2013, p. 67.

Fig. 170 (0) - (...) Teatro de Sagunto.

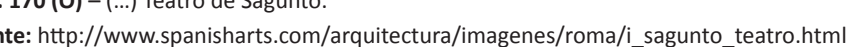

Fig. 171 - Modelo virtual da área do teatro, onde é possivel ver a altimétria e configuraçăo do terreno.

Fonte: Modelo virtual realizado pelo autor, 2011

Fig. 172 - Tracado do teatro sobre altimétria do terreno.

Fonte: Desenhich

Fig. 173 - Traçado do teatro de Tongobriga integrado no quadriculado da cidade.

Fig. 174 - Teatro de Bracara Augusta integrado no quadriculado da cidade.

Fig. 175 - Teatro de Óstia

ntica.net/immagini.php?aid=5

Fig. 176 - Estruturas identificadas a

Fig. 177 - Hipotese de tracado para o teatro de Bracara Augusta, por Ricardo Mar.

Fonte: Manuela Martins, Ricardo Mar, Jorge Ribeiro e Fernanda Magalhăes, "A construusão do teatro romano de

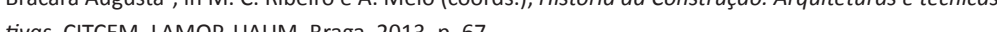

Fig. 178 - Sobreposiç̃ão do traçado do teatro de Tongobriga e de Bracara Augusta

onte: Sobreposiçăo realizada pelo autor, 2011

Fig. 179 - Delineamento do perfil transversal da cavea com uma pendente de 25 graus

Fonte: Desenho realizado pelo autor, 2011.

Fig. 180 - Pendentes de cavea em diferentes teatros.

Fone. Esquema realizado pelo autor, 201.

Fig. 181 - Aplicação do corte de Bracara Augustan no caso de Tongobriga.

Fonte: Esquema (des) realizado pelo antor, 2011 Corte do teatro de Brocara Anusta segundo Ricardo Mar.

Fig. 182 - Hipótese do limite de cavea com duas ordens (A). Com uma ordem (B).

. Esquema (des) realizado pelo autor, 2011 .

Fig. 183 - Hipótese do limite de cavea com duas ordens.

Fonte: Esquema realizado pelo autor, 2011.

Fig. 185 - Desenhos interpretativos dos preceitos vitruvianos, segundo Thomas Noble How

2006, pp. 206-207.

Fig. 186 - Aplicação do traçado de Vitrúvio no teatro de Tongobriga, por forma a determinar o palco.

enho realizado pelo autor, 2011.

Fig. 187 - Aplicação dos preceitos de Vitrúvio no que diiz respeito à divisão da cavea.

Fig. 188 (A) - Posiçăo dos aditus face à cavea. Exemplo do teatro de Mérida. Fonte: Pierre Gros, L'Architecture Ro
ments Publics, vol. I, 1996, p. 292.

Fig. 188 (B) - Posiçăo dos aditus face à cavea. Exemplo do teatro de Bracarar Augusta

Fonte: Manuela Martins, Ricardo Mar, Jorge Ribeiro e Fernanda Magalhães, "A construção do teatro romano de Bracara Augusta", in M. C. R. Ribeiro e A. Melo (coords.), História da Construscäo. Arquiteturas e técricas Construtivas, IITCEM, LAMOP, UAUM, Braga, 2013, p. 67 .

Fig. 189 (A) - Composiçăo do corpo cénico. Teatro de Ferento.

av. J.C. à la fin du Haute-Empire - Les Mon-
Fig. 189 (B) - Composiçäo do corpo cénico. Teatro de Orange.

20 ments Publics, vol. I, 1996, p. 272.

Fig. 189 (C) - Composiçăo do corpo cénico. Teatro de Herculanum.

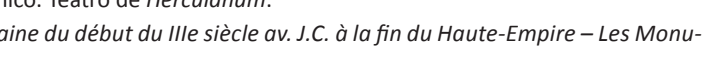
ments Publics, vol. I, 1996, p. 285

Fig. 189 (D) - Composição do corpo cénico. Teatro de Mérida ments Publics, vol. I, 1996, p. 2 . 292.

Fig. 190 - Hipótese de reconstituição para o corpo cénico e porticus postscenium

Fig. 191 (A) - Largura do pátio (peristilo). Teatro de Mérida.

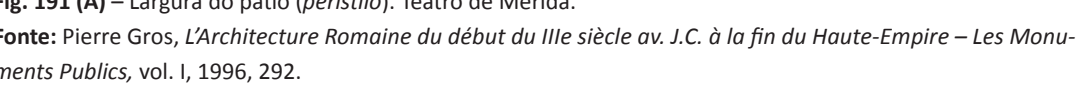

Fig. 191 (B) - Largura do pátio (peristilo). Teatro de Bracara Augusta.

Fonte: Manuela Martins, Ricardo Mar, Jorge Ribeiro e Fernanda Magallhâs, "AA construção do teatro romano de Bracara Augusta", in M. . C. Riberio e A. Melo (coor
tivas, CITCEM, LAMOP, UAUM, Braga, 2013, p. 67

Fig. 192 - Proposta de reconstituiçăo do teatro de Tongobrigo

fonte: Desenho realizado pelo autor, 2011.

ig. 193 - Enquadramento do centro civico no quadriculado actus.

Fonte: Desenho realizado pelo autor, 201

Fig. 194 - Traçado hipotético de Verona, baseado no esquema triângulo-equilátero-e-circulo-inscrito.

Tark Wilson Jones, Principles of roman architecture, 2005, p. 61.

Fig. 195 - Hipotese de implantacăao do anniteatı.
Fonte: Desenho realizado pelo autor, 2011.

fig. 196 - Hipótese de implantação, perfil.

Fonte: Desenho realizado pelo autor, 2011

Ag. 197 - Teatro e antiteatro de Emerta Augusta. Vista aérea

Fonte: Imagem do Bingmaps (imagem de 2011).

fig. 198 - Proposta de implantação para o hipotético anfiteatro.

fonte: Desenho realizado pelo autor, 2011

Fig. 199 - Esquemas de composiçăo do centro civico.

Fonte: Esquema realizado pelo autor, 2011.

Fig. 200 - Espaço do centro civico. Vista aérea no sentido poente-nascente.

Fonte: Fotografia aérea cedida pela Estą̧ã Arqueológica do Freixo.

Fig. 201 - Conjunto de elementos assinalados através do uso do quadriculado Actus Quadractus, após desco-

Fig. 202 - Ilustração da reconstituiç̃ão do cent
Fonte: llustraçăo realizada pelo autor, 2011.

Fig. 203 - Hipótese de nova posiç̧̃o da muralha.

Fig. 204 - Reconstituicão do centro civico sobre a paisgeem. Fotomontagem.
Fonte: Fotomontagem realizada pelo autor, 2013.

Fig. 205 - Hipótese da troca de posição entre teatro e anfiteatro. Planta.

Fonte: Desenho realizado pelo autor, 201 


\section{DESENHOS}




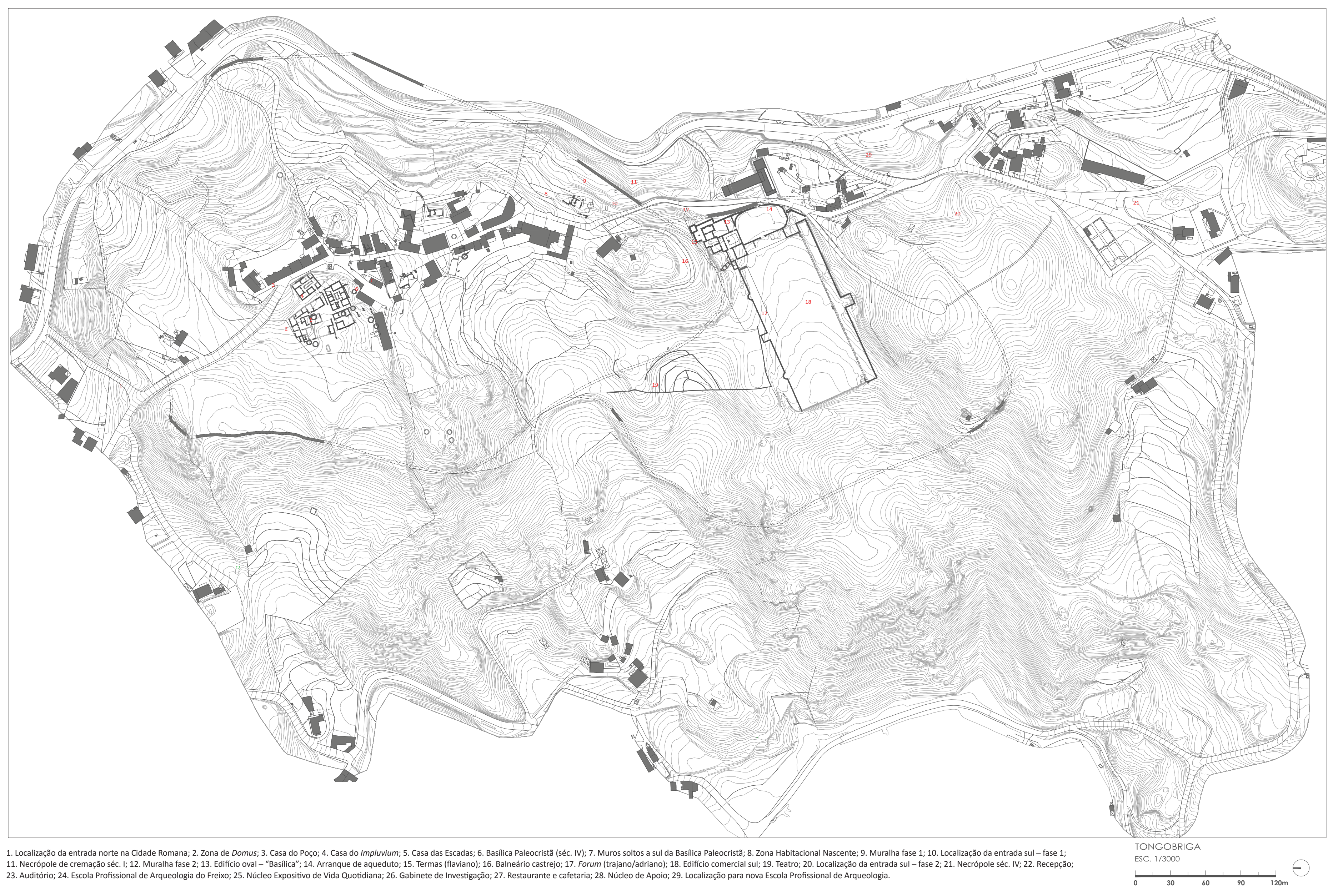




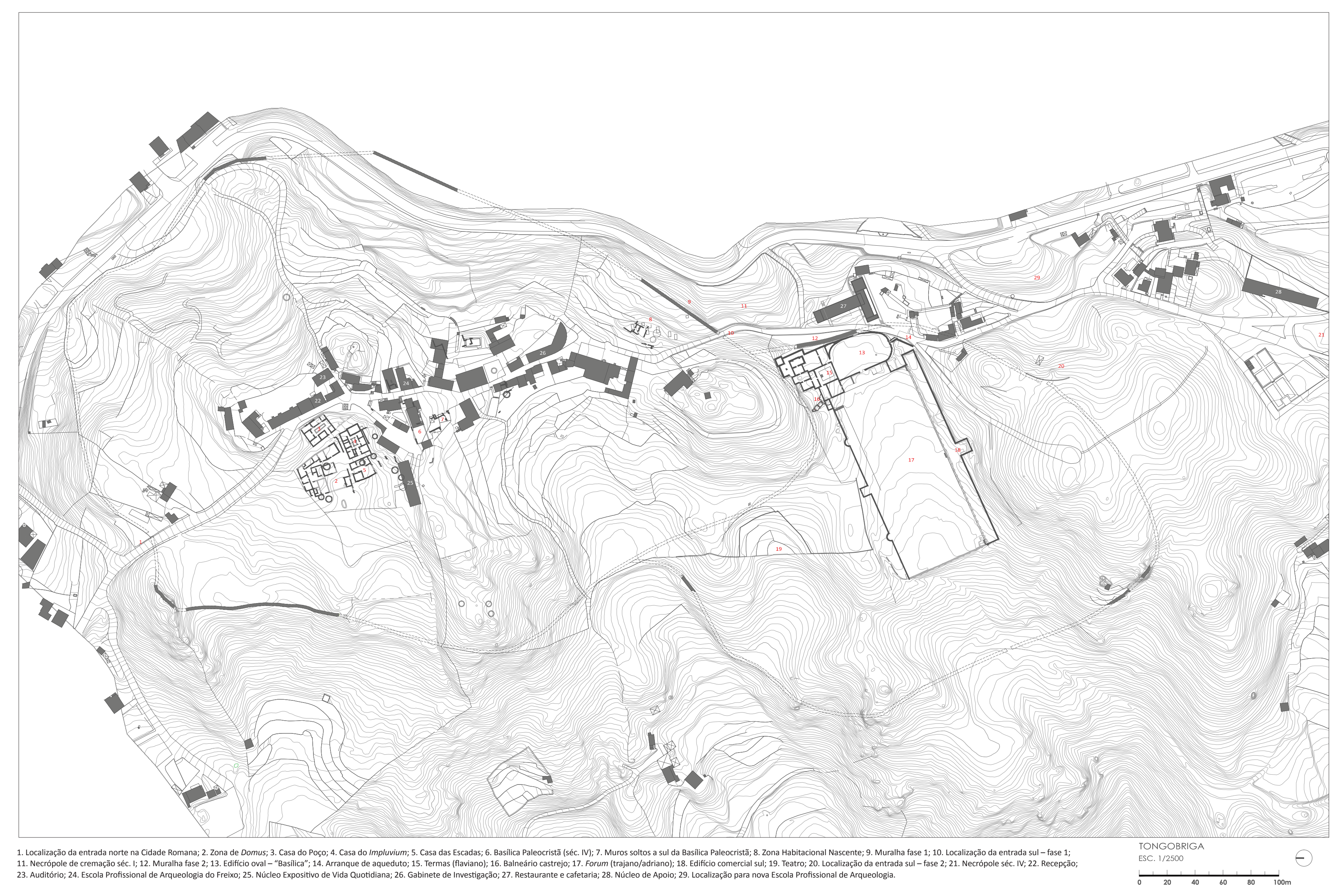




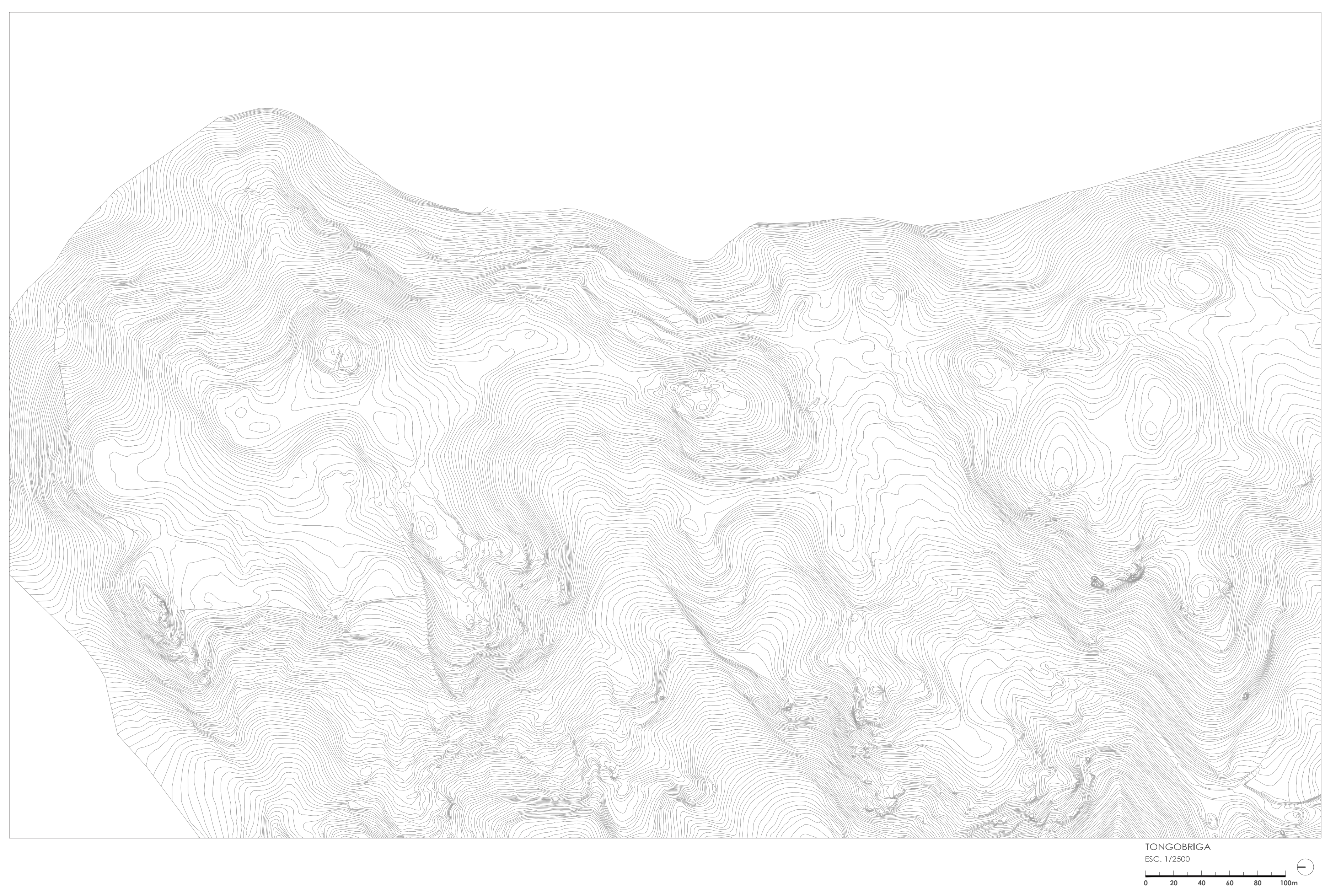




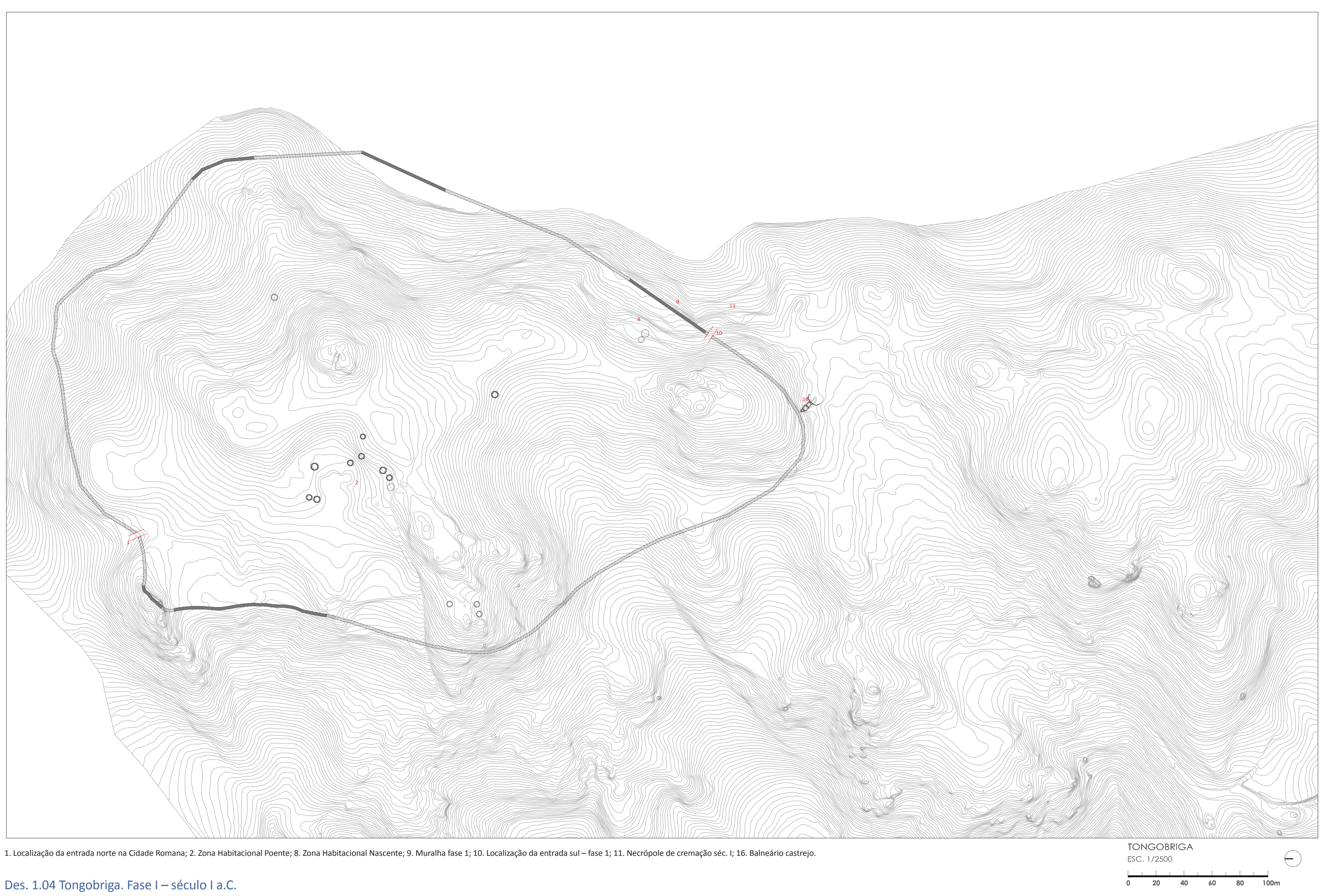




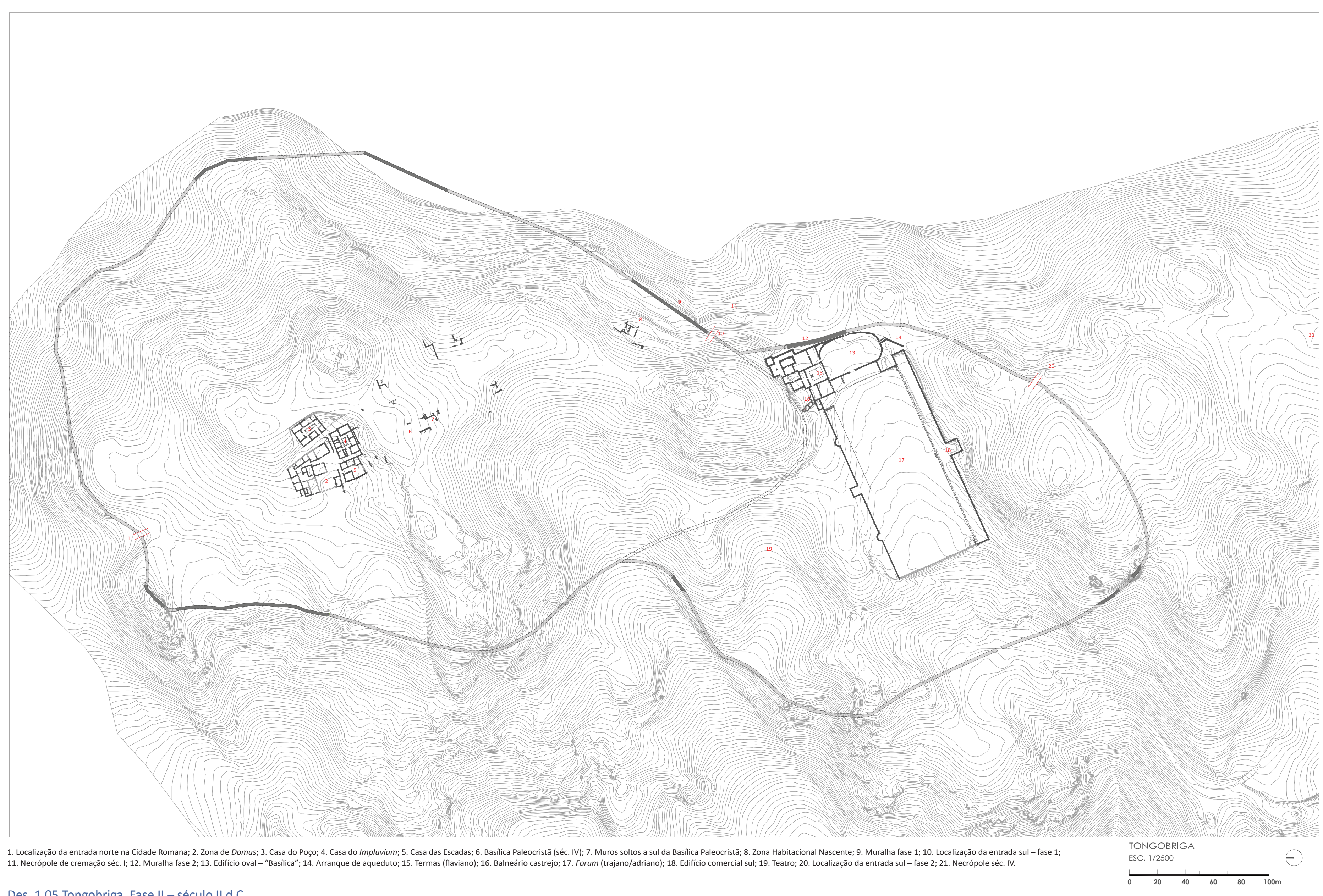

Des. 1.05 Tongobriga. Fase II - século II d.C. 


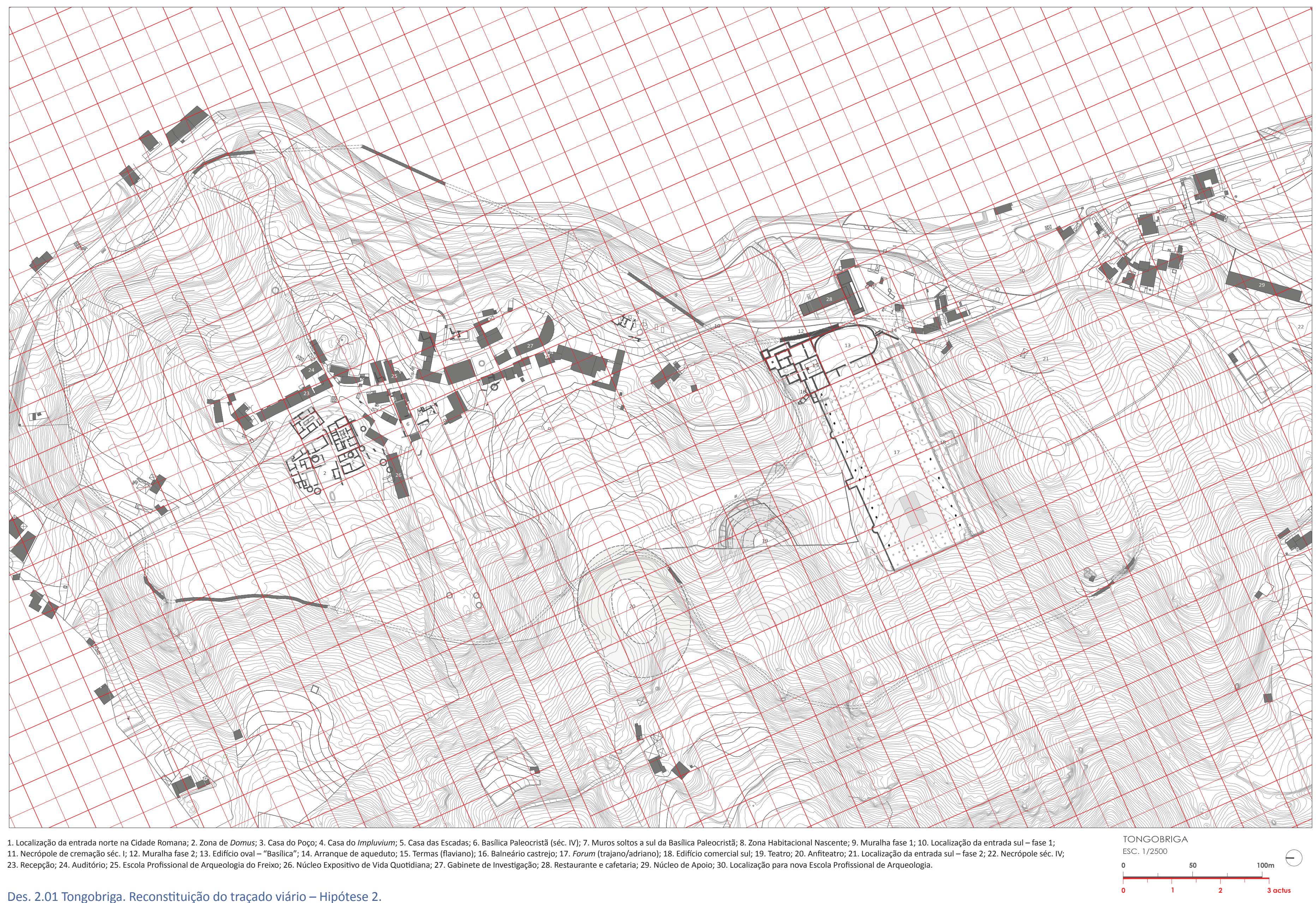




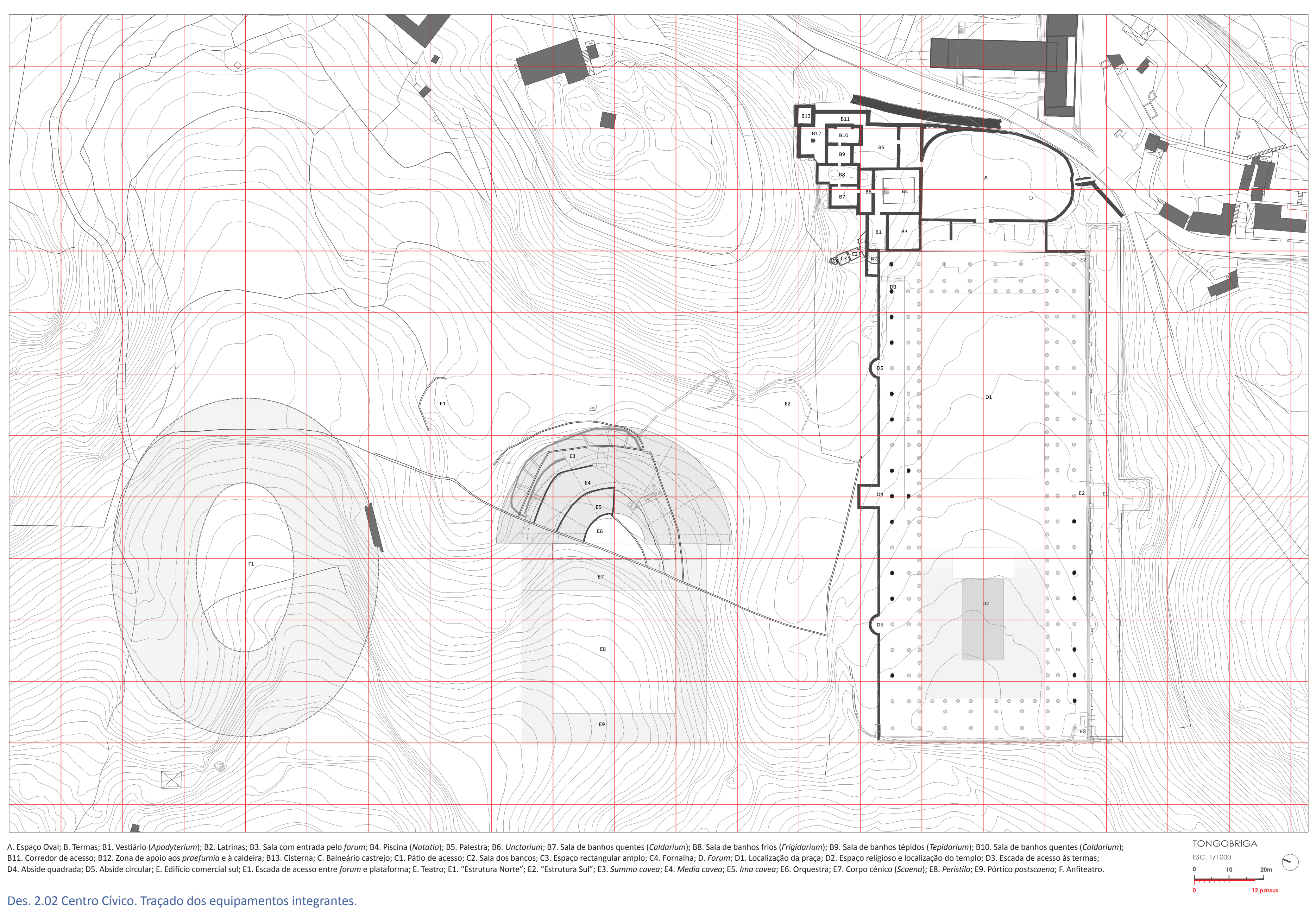




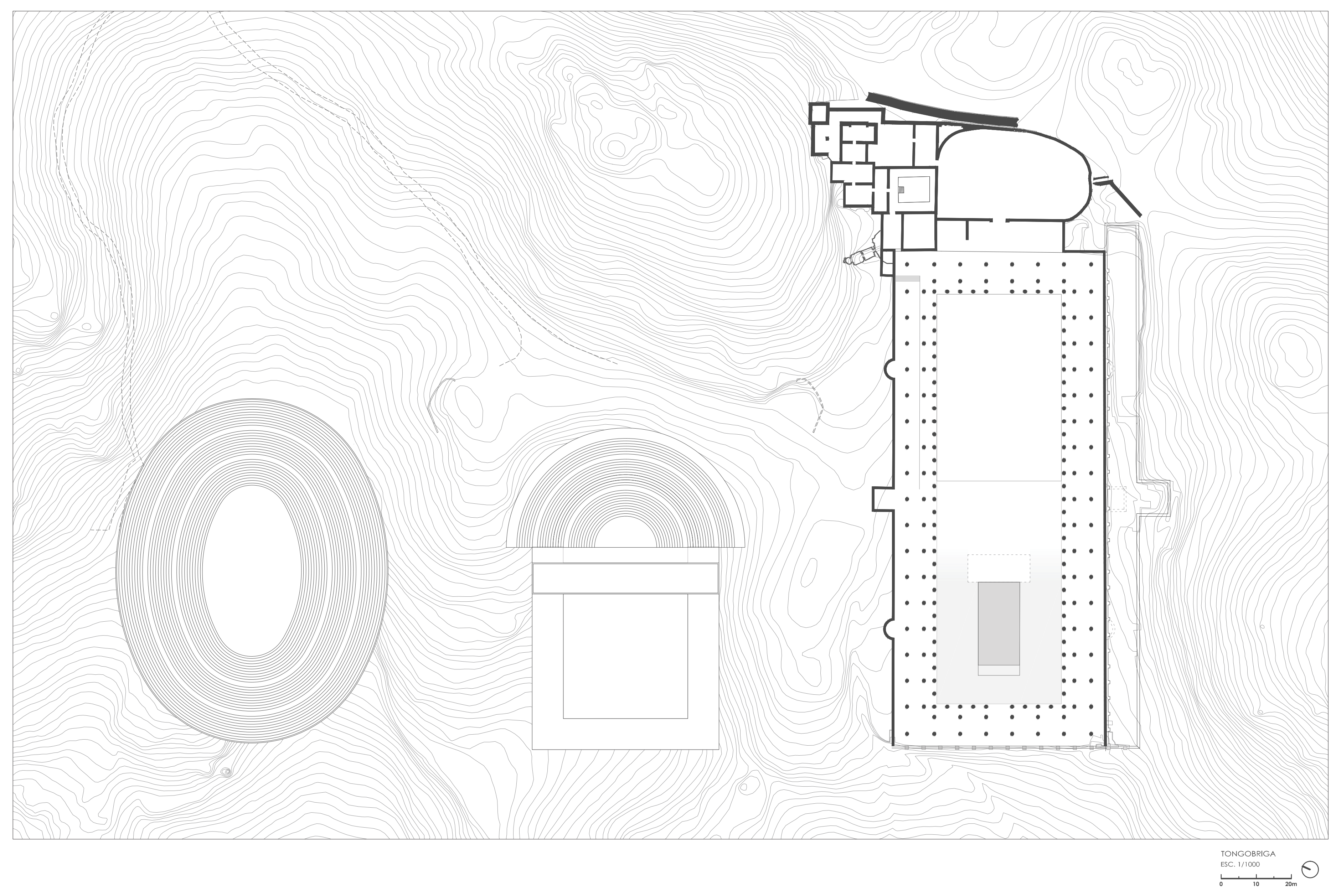

Des. 2.03 Centro Cívico. Reconstituição. 
TONGOBRIGA

REFLEXÕES SOBRE

O SEU DESENHO URBANO

CHARLES ROCHA

LINO TAVARES DIAS

PEDRO ALARCÃO

\section{TONGOBRIGA}

REFLEXÕES SOBRE

O SEU DESENHO URBANO
LINO TAVARES DIAS

PEDRO ALARCÃO

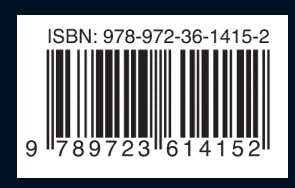

